Andrews University

Digital Commons @ Andrews University

2005

\title{
A Strategy for Revitalization and Growth of the Seventh-day Adventist Church in Iceland
}

John Eric Gudmundsson

Andrews University

Follow this and additional works at: https://digitalcommons.andrews.edu/dmin

Part of the Practical Theology Commons

\section{Recommended Citation}

Gudmundsson, John Eric, "A Strategy for Revitalization and Growth of the Seventh-day Adventist Church in Iceland" (2005). Professional Dissertations DMin. 631.

https://dx.doi.org/10.32597/dmin/631

https://digitalcommons.andrews.edu/dmin/631

This Project Report is brought to you for free and open access by the Graduate Research at Digital Commons @ Andrews University. It has been accepted for inclusion in Professional Dissertations DMin by an authorized administrator of Digital Commons @ Andrews University. For more information, please contact repository@andrews.edu. 


\section{ABSTRACT}

\section{A STRATEGY FOR REVITALIZATION AND GROWTH OF THE SEVENTH-DAY ADVENTIST CHURCH IN ICELAND}

by

Jorgen Eric Gudmundsson

Adviser: Douglas Robert Kilcher 


\title{
ABSTRACT OF GRADUATE STUDENT RESEARCH
}

\author{
Dissertation
}

\author{
Andrews University \\ Seventh-day Adventist Theological Seminary
}

\section{Title: A STRATEGY FOR REVITALIZATION AND GROWTH OF THE SEVENTH- DAY ADVENTIST CHURCH IN ICELAND}

Name of researcher: Jorgen Eric Gudmundsson

Name and degree of adviser: Douglas Robert Kilcher, D.Min.

Date completed: May 2006

The Topic

This dissertation analyzes the growth pattern of the Adventist church in Iceland from its inception about a hundred years ago to the present and presents an objective portrayal of the future possibilities of church growth on the island and develops a practical strategy of revitalization of the church.

\section{The Purpose}

The proposed strategy presented in this project aims at increasing the quality of life of the Icelandic Adventist churches, raising their self-identity and sense of mission, and strengthening their ability to reach the community and to grow. 
The Sources

A Biblical theological rationale for this program is set forth as well as an overview of the counsel of Ellen G. White for its accomplishment. A review of literature of main sources on church growth and revitalization is presented with principal emphasis on the School of Church Growth, spearheaded by Donald McGavran and his associates, and literature on recent developments and responses of churches to the change in the philosophical environment in a postmodern era is also reviewed. The historical analysis of the growth pattern of the Adventist Church in Iceland from its inception to the present is based on church membership records, minutes of the conference executive committee, reports from conference constituency meetings and on two unpublished Seminary papers prepared on early history of Adventism in Iceland and a D. Min. dissertation on Adventist church growth in Iceland from 1950 to 1980 . Further, the future model strategy for the revitalization and growth of the work among the above churches is based on that of the Natural Church Development by Christian A. Schwarz and associates who have successfully constructed a valid evaluating instrument and quality index applicable to churches using world wide survey data as a reference.

\section{Conclusion}

In view of the present less than ideally functioning local Adventist congregations in Iceland with respect to local leadership and lay evangelism, a renewal of their vision is of paramount importance. They are in need of a change of operational paradigm from that of settled pastors in churches and minimal involvement in evangelism and must alter their present perception of the impossibility of success in outreach. They need to learn from the 
strengths of the early program of the church to visibly identify with society and to engage in an authentic contribution to its well-being and to conduct a vigorous, church based program of evangelism and outreach. They must also shun its weaknesses which were lack of lay involvement and training and a relegating of primary care of members as well as evangelism and outreach almost solely to the pastoral staff which contributed to its stagnation and later decline. 


\begin{abstract}
Andrews University
Seventh-day Adventist Theological Seminary
\end{abstract}

\title{
A STRATEGY FOR REVITALIZATION AND GROWTH OF THE SEVENTH-DAY ADVENTIST CHURCH IN ICELAND
}

\author{
A Dissertation \\ Presented in Partial Fulfillment \\ of the Requirements for the Degree \\ Doctor of Ministry
}

by

Jorgen Eric Gudmundsson

November 2005 



\title{
A STRATEGY FOR REVITALIZATION AND GROWTH OF THE SEVENTH-DAY ADVENTIST CHURCH IN ICELAND
}

\author{
A Project/Dissertation \\ Presented in Partial Fulfillment \\ of the Requirements for the Degree \\ Doctor of Ministry
}

by

Jorgen Eric Gudmundsson

APPROVAL BY THE COMMITTEE:

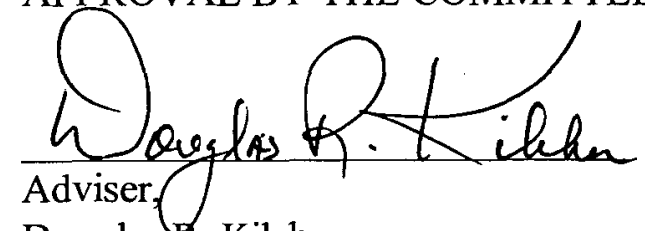

Douglas K. Kilcher
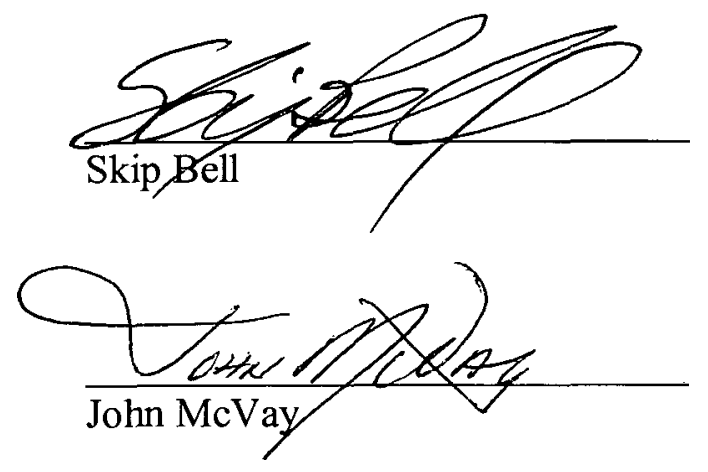
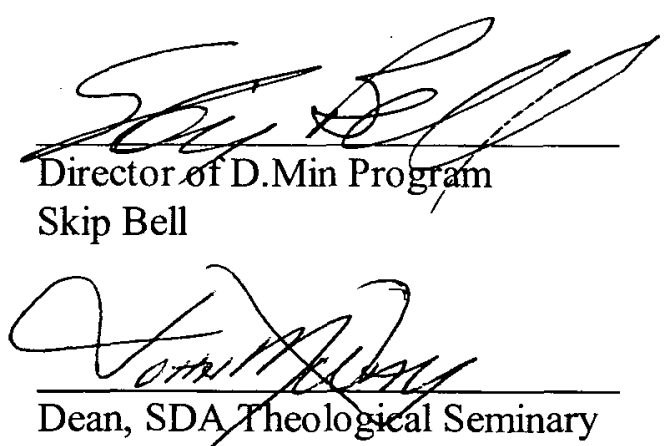
John Mc $\checkmark$ ay

$\frac{\text { May 4,2006 }}{\text { Date approved }}$ 
To my wife,

Laila Mary, and to my sister, Sonja,

whose faithful and consistent encouragement and untiring patience has made this project become a reality. 


\section{TABLE OF CONTENTS}

LIST OF FIGURES $\ldots \ldots \ldots \ldots \ldots \ldots \ldots \ldots \ldots \ldots \ldots \ldots \ldots \ldots \ldots \ldots \ldots \ldots$

Chapter

I. INTRODUCTION $\ldots \ldots \ldots \ldots \ldots \ldots \ldots \ldots \ldots \ldots \ldots \ldots \ldots \ldots \ldots \ldots \ldots$

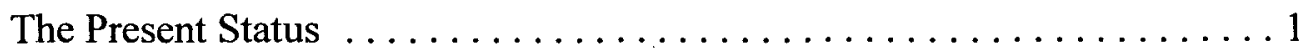

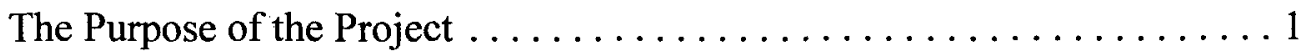

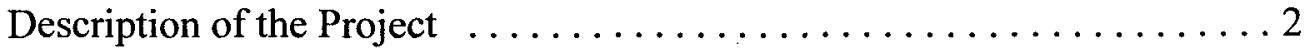

II. THEOLOGICAL FOUNDATIONS FOR A STRATEGY OF CHURCH GROWTH IN THE ADVENTIST CHURCHES IN ICELAND IN SCRIPTURE AND THE SPIRIT OF PROPHECY $\ldots \ldots \ldots \ldots \ldots \ldots \ldots \ldots \ldots \ldots$

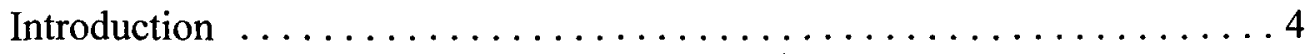

The Mission Mandate in the Great Commission $\ldots \ldots \ldots \ldots \ldots \ldots \ldots 6$

A Missionary Gospel ....................... 6

The Method of Mission: The Making of Disciples ........... 8

The Content of Mission: The Gospel of the Kingdom .......... 9

The Motivation For Mission: The Experience of the Loving Lord . . . 10

The Addressees of Mission: The Nations and the Little Ones . . . . 11

The Subjects of Mission: A Church of Disciples ........... 12

The Great Commission of the Other Gospels $\ldots \ldots \ldots \ldots \ldots \ldots \ldots 13$

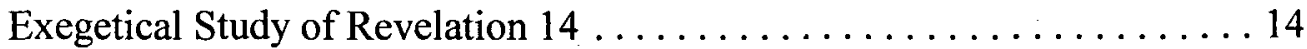

The Importance of Revelation 14 in Adventist Context ........ 14

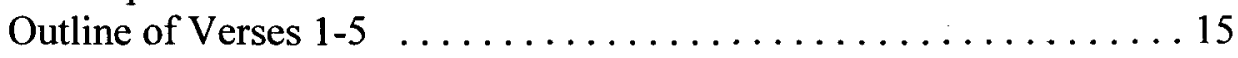

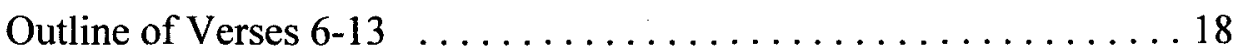

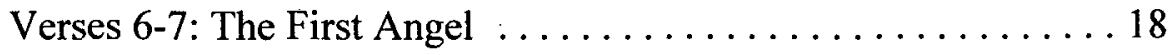

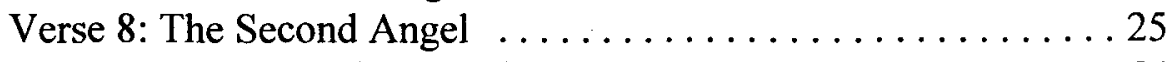

Verses 9-13: The Third Angel $\ldots \ldots \ldots \ldots \ldots \ldots \ldots \ldots \ldots . \ldots \ldots$

The Relationship Between the Great Commission and the

Message of the Three Angels in Revelation $14 \ldots \ldots \ldots \ldots \ldots \ldots 32$

The Missiological Questions Applied to Revelation 14:1-13 . . . . 32

The Method of Mission . . . . . . . . . . . . . . . . 32

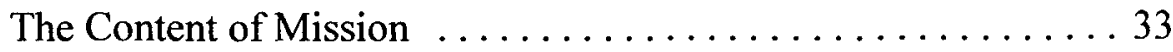

Motivation for Mission .......................... 34

The Addressees of Mission . . . . . . . . . . . . . . . 34 
The Subjects of Mission . . . . . . . . . . . . . . . 35

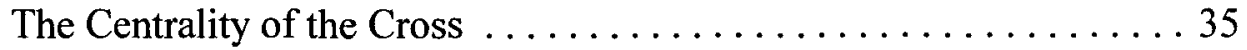

The Missionary Role of the Church in Ephesians ............. 38

The Oneness of the Body ......................... 39

The Church's Mission in Holiness $\ldots \ldots \ldots \ldots \ldots \ldots \ldots \ldots . \ldots . \ldots$

The Universality of the Mission of the Church ............ 41

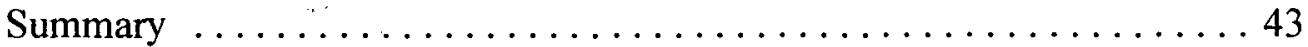

Mission and Ministry of the Church in the Writings of Ellen G.

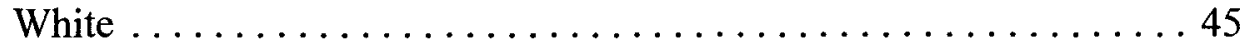

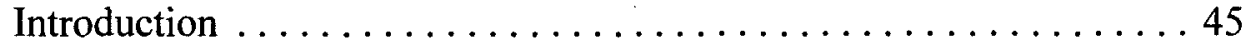

Contextual Factors Relating to the Counsel of Ellen G. White . . . . 4 46

The Nature and the Role of the Church $\ldots \ldots \ldots \ldots \ldots \ldots \ldots \ldots . \ldots 48$

The Authority of the Church ...................... 49

The Ordination of Ministers, the Gifts of the Spirit, and a Call for

Church Unity ............................... 50

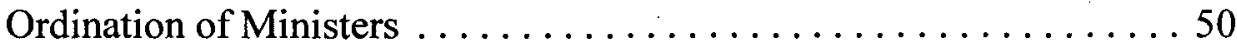

Varied Gifts of the Spirit in the Church $\ldots \ldots \ldots \ldots \ldots \ldots \ldots . \ldots . \ldots 52$

The Call for Church Unity ........................ 53

Descriptions of the Role of the Ministry .................. 57

A Watchman ................................. 57

Representatives of Christ $\ldots \ldots \ldots \ldots \ldots \ldots \ldots \ldots \ldots$

Faithful Shepherds of the Flock .................... 59

Charged to Tell of the Binding Claims of God's Law ......... 59

The Priority of Evangelism $\ldots \ldots \ldots \ldots \ldots \ldots \ldots \ldots \ldots \ldots . \ldots \ldots$

Ministers Called to Raise Up New Churches .............. 60

Ministers Not to Spend Too Much Time with the Converted ......66 60

Pastoral Work In the Churches $\ldots \ldots \ldots \ldots \ldots \ldots \ldots \ldots . \ldots 6$

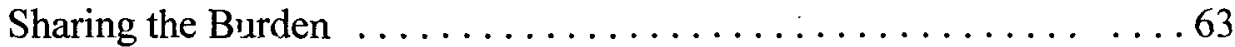

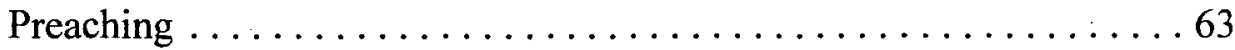

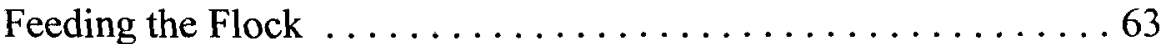

Short Sermons . . . . . . . . . . . . . . . . . . . 65

Not a Sermon Every Sabbath $\ldots \ldots \ldots \ldots \ldots \ldots \ldots \ldots 66$

The Social Meeting ............................ 66

The Importance of Personal Work $\ldots \ldots \ldots \ldots \ldots \ldots \ldots 6 . \ldots 67$

Personal Work and Visitation .....................67 67

The Importance of Getting Close to People . . . . . . . . . . . 69

The Importance of Understanding and Adapting to People's

Needs ..............................69 69

The Role of the Laity in the Church $\ldots \ldots \ldots \ldots \ldots \ldots \ldots \ldots \ldots \ldots \ldots$

The Necessity of Involving Lay People in Active Service . . . . . . . 71

Importance of the Work of the Church Members . . . . . . . 72

United effort-Essential to Mission Success . . . . . . . . . . 73

Lay People to Be Allowed to Serve ............... 74

The Beneficial Effect of Active Involvement ............ 74

Must Put New Members to Work Immediately ........... 76 
The Training of Lay People for Service $\ldots \ldots \ldots \ldots \ldots \ldots \ldots 77$

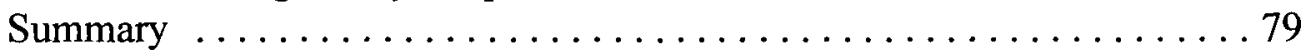

\section{PRINCIPLES AND PRAXIS OF CHURCH GROWTH: A REVIEW OF}

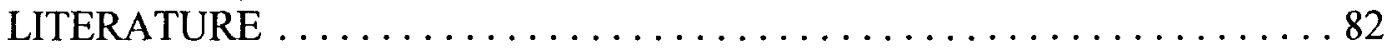

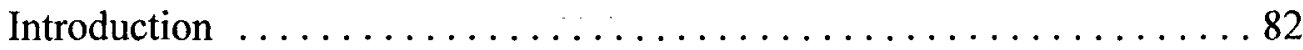

The Church Growth Movement . .................. 82

Beginnings of the Church Growth Concept-Donald McGavran . . . . 882

Voices of Criticism ........................... 85

Subsequent Developments $\ldots \ldots \ldots \ldots \ldots \ldots \ldots \ldots \ldots$. . . . . . . . 87

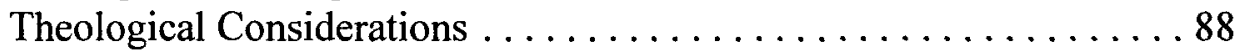

Church Growth Principles-Fundamental Concepts . ............ 91

The Relationship of Evangelism and Church Growth ........... 92

Sources of Growth ......................... 93

Classification of Evangelism . . . . . . . . . . . . . . . . . . . . . 993

Types of Church Growth ....................... 94

An Interpretive Framework for Understanding Patterns of Church

Growth and Decline ......................... 94

Church Growth Principles-Strategies for Growth . . . . . . . . . . 96

Signs of Church Health and Disease . . . . . . . . . . . 96

Signs of Church Vitality-Survey of Baptist Churches in England . . .98

Seven Vital Signs . ...................... 99

Survey of Baptist Churches-Paul Beasley-Murray and Alan

Wilkinson ............................ .99

Statistical Analysis of Church Growth Principles-C. Kirk Hadaway . . . 102

Evangelism and Outreach . ....................... 103

The Age-Structure of the Congregation $\ldots \ldots \ldots \ldots \ldots \ldots \ldots . \ldots 104$

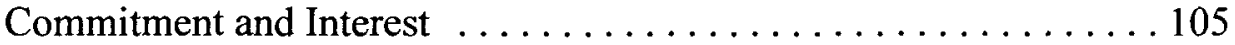

Other Factors Having Substantial Effect on Growth .......... 106

Supporting Factors to the Primary Principles and

Contextual Factors ........................... 106

Cell Groups and Church Growth-The Class Meeting in Early

Methodism .............................. 107

Origins and Significance of the Class Meeting ............ 108

Background to the Rise of the Class Meeting in Methodism ... 109

The Rise of the Class Meeting . .................. 112

Form and Dynamics of the Class Meeting $\ldots \ldots \ldots \ldots \ldots \ldots 114$

The Significance of the Class Meeting $\ldots \ldots \ldots \ldots \ldots \ldots \ldots \ldots \ldots \ldots \ldots$

The Effects of the Class Meeting in Methodism ............. 117

The Testimony of George Whitefield . . . . . . . . . . . 117

The Class Meeting and the Christian Witness on the Frontier . . 119

The Class Meeting and Christian Discipline $\ldots \ldots \ldots \ldots \ldots 120$

The Class Meeting and the Engagement of the Laity . . . . . 122

The Class Meeting and Evangelistic Outreach ............ 123

Summary ............................... 124 
Church Growth in Contemporary Culture-Preaching Christ to the

Postmodern Mind .............................. 125

From Modernism to Postmodernism . . . . . . . . . . . . . 127

The Modern Mind . . . . . . . . . . . . . . . . . . . . . . . 127

Rejection of Modernism . . . . . . . . . . . . . . . 130

Postmodern Philosophers ........................ 132

Description of the Postmodern Worldview ............ 133

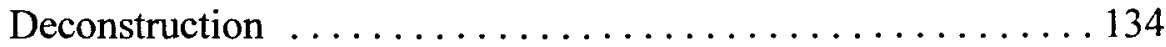

From Modern to Postmodern Theology $\ldots \ldots \ldots \ldots \ldots \ldots \ldots \ldots . \ldots 135$

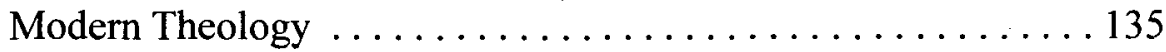

Types of Postmodern Theology .................. 136

Preaching Christ in a Postmodern Age ................ 137

The Postmodern Generation ..................... . 137

The World of the Postmodern Generation ............. 137

Window of Opportunity . . . . . . . . . . . . . . . . . 138

The Healing Community $\ldots \ldots \ldots \ldots \ldots \ldots \ldots \ldots \ldots \ldots$

Experimental Religion: The Interactive Method of Presenting the Gospel ............................ 140

A Holistic Gospel ......................... 142

The Gospel of Power ......................... 143

The Church's Reaction to the Challenge of Postmodernism . . . . . . . 144

From Market Driven to Mission Oriented ............. 145

From Following Celebrities to Encountering Saints ......... 146

From Dead Orthodoxy to Nurturing Living Faith ......... 147

From Attracting Crowd to Seeking the Lost . . . . . . . . . . . 149

The Missiological Challenge ..................... 151

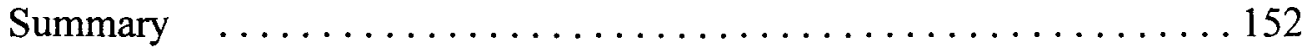

IV. THE ADVENTIST MISSION IN ICELAND: THE INDIGENOUS MILIEU AT ITS ARRIVAL AND ITS GROWTH AND DEVELOPMENT $\ldots \ldots .154$

Introduction .................................... 154

Iceland at the Time of the Arrival of the Advent Mission .......... 155

Winds of Change-The Struggle for Independence .......... 155

Influence of Urbanization on Religious Life 157

Economic Changes ........................ 157

The Influence on the Religious Life of the Nation . . . . . . . 159

Secularization of Society . . . . . . . . . . . . . . . . . 161

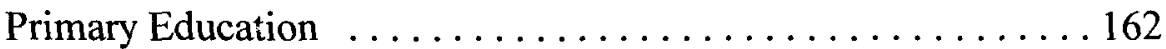

Local Government ......................... 162

Dawn of Religious Pluralism In Iceland $\ldots \ldots \ldots \ldots \ldots \ldots \ldots \ldots . \ldots \ldots$

Dissatisfaction with the Church and the Emergence of Religious

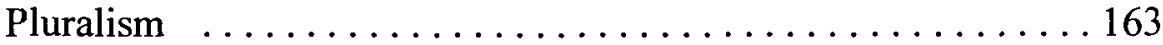

The Free-Church Movement and Religious Pluralism . . . . . . . 165

Rev. Lárus Halldórsson . . . . . . . . . . . . . . . . . . . 166

Liberal Theology-The Church's Bid for Renewal . . . . . . . . . 172 


\section{A MODEL STRATEGY FOR GROWTH OF THE ADVENTIST}

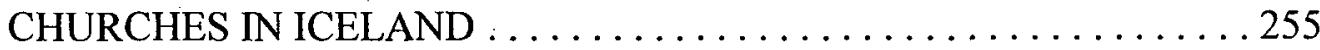

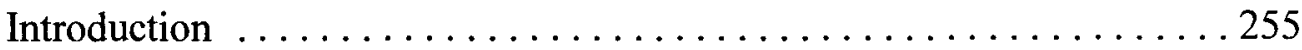

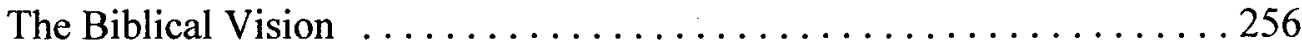

An Emphasis on Mission and the Engagement of the

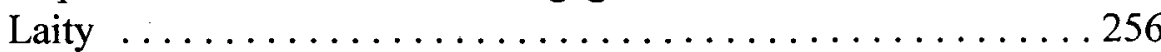

Church Growth in the Adventist Context . .............. 257

The Adventist Mission By an Apostolic Church . . . . . . . . . . . 258

The Interactive Method of Preaching the Gospel . . . . . . . . . . . . 259

Strategic Approach-Natural Church Development . . . . . . . . . . . . 261

International Church Survey . . . . . . . . . . . . . . . . . . . 261

The "All By Itself" Principle . . . . . . . . . . . . . . . . . . . 261

The Eight Quality Characteristics ................... 262

The Minimum Factor and the Church Profile ............ 263

The Biotic Principles ......................... 263

Spiritualizing and Technocratic Paradigms ............... 264

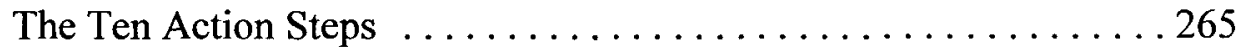

Applicability to the Present Situation ................. 265

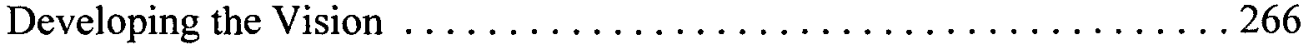

The Role of the Pastor ......................... 266

The Core Group ............................ 268

Establishment of Small Groups ...................... 269

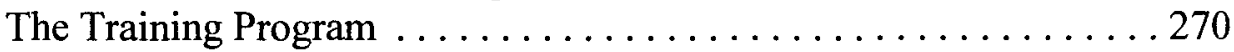

General Courses ............................ 270

Local Courses ................................. 270

Practical Application of the Eight Quality Characteristics ........271

Monitoring Growth Achievements .................271

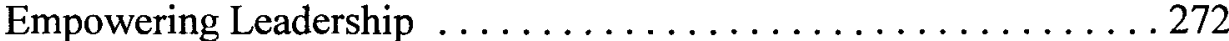

Description ..............................272

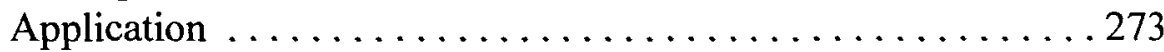

Gift Oriented Ministry . . . . . . . . . . . . . . . . . . . . . 273

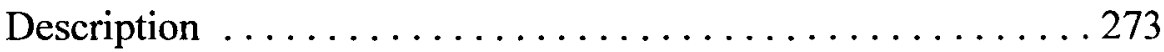

Application ...............................274

Passionate Spirituality . . . . . . . . . . . . . . . . . . . . . . . 274

Description .............................274

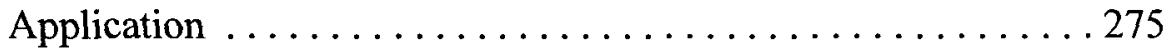

Functional Structures ......................... 276

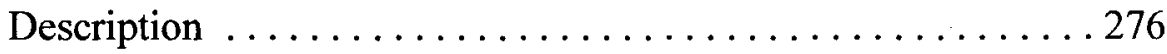

Application ............................. 277

Inspiring Worship Service ........................ 279

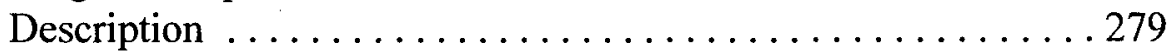

Application ...............................2280

Holistic Small Groups .......................... 281 
Description .............................281

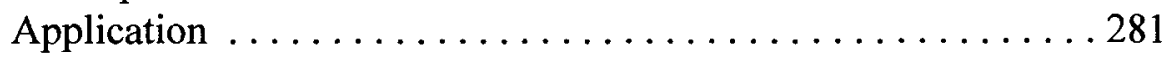

Need-Oriented Evangelism ..................... 282

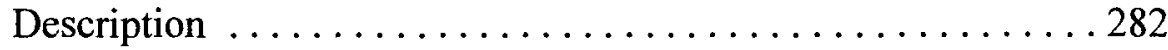

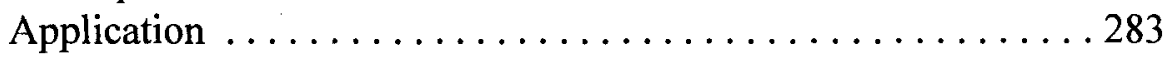

Loving Relationships ......................... 284

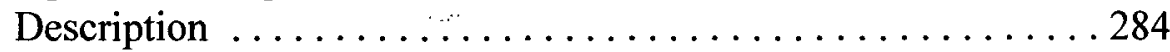

Application ...........................285

Continuation of the Process and Evaluation .............. 287

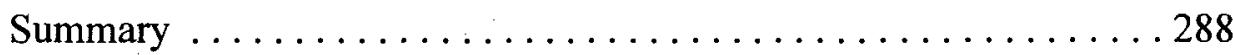

VI. SUMMARY, CONCLUSIONS AND RECOMMENDATIONS . . . . . . 290

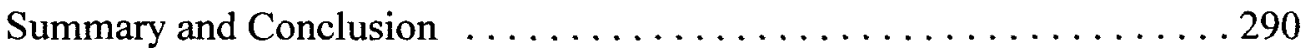

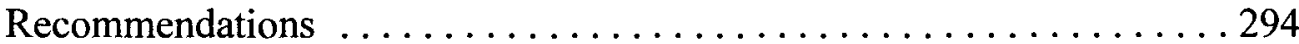

Introduction . . . . . . . . . . . . . . . . . . . . . . 294

Key Issues in the Implementation Process of Renewal . . . . . . . 295

A Vision of a Searching God .................... 295

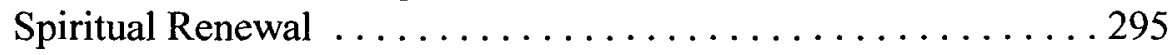

A Sense of Purpose and Mission ................. 296

Reclaiming of First Love ..................... 297

Strategy of Evangelism ...................... 298

Role of the Conference in Evangelism ............. 300

Role of the Local Church .......................... 301

Small Group Ministry and Lay Participation ............. 301

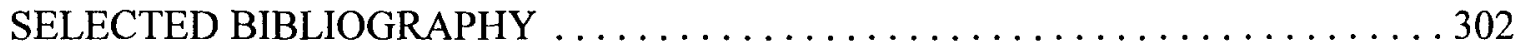

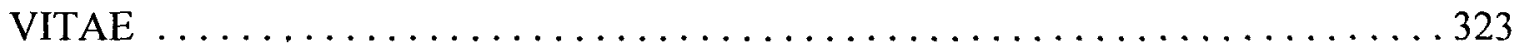




\section{LIST OF FIGURES}

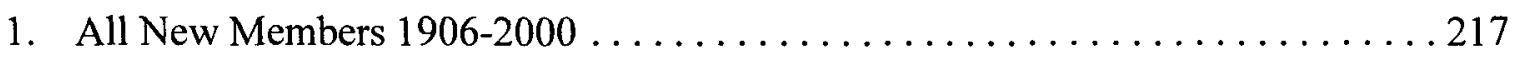

2. Denominational Background of New Members, $1926-1950$............ 219

3. Baptism of Individuals from SDA Background, $1950-1960 \ldots \ldots \ldots \ldots \ldots 222$

4. Average Per Year Student Attendance at HDS, $1951-1980 \ldots \ldots \ldots \ldots \ldots 223$

5. Baptism of Individuals from Non-SDA Background, $1951-1980 \ldots \ldots \ldots \ldots 224$

6. Total Number of Individuals Baptized, $1951-1980 \ldots \ldots \ldots \ldots \ldots \ldots \ldots 225$

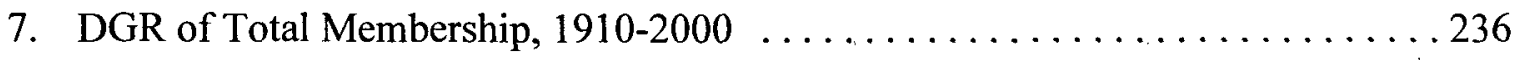

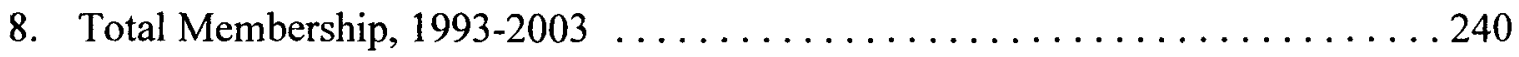

9. Yearly Growth Rate of Total Membership, $1993-2003 \quad \ldots \ldots \ldots \ldots \ldots \ldots 240$

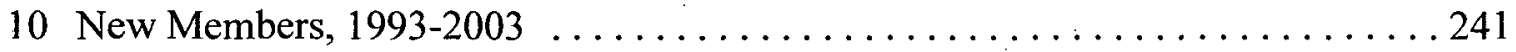

11. Reykjavík Church-Total Membership, $1995-2004 \ldots \ldots \ldots \ldots \ldots \ldots \ldots 242$

12. Reykjavík Church-Acquisitions and Losses, $1995-2004 \ldots \ldots \ldots \ldots \ldots 243$

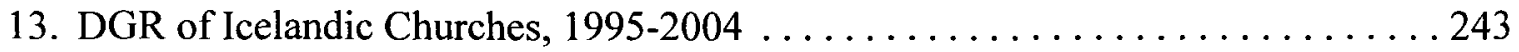

14. Hafnarfjörður Church-Total Membership, $1995-2004 \ldots \ldots \ldots \ldots \ldots \ldots 244$

15. Hafnarfjörður Church-Acquisitions and Losses, 1995-2004 ............ 245

16. Suðurnes Church-Total Membership, $1995-2004 \ldots \ldots \ldots \ldots \ldots \ldots \ldots 246$

17. Suðurnes Church-Acquisitions and Losses, $1995-2004 \ldots \ldots \ldots \ldots \ldots \ldots . \ldots 246$

18. Árnes Church-Total Membership, $1995-2004 \ldots \ldots \ldots \ldots \ldots \ldots \ldots \ldots$

19. Árnes Church-Acquisitions and Losses, $1995-2004 \ldots \ldots \ldots \ldots \ldots 248$ 
20. Vestmannaeyjar Church-Total Membership, 1995-2004 249

21. Vestmannaeyjar Church-Acquisitions and Losses, $1995-2004$. . . . . . . . . 250

22. Conference Church-Total Membership, $1995-2004 \ldots \ldots \ldots \ldots \ldots \ldots \ldots 251$

23. Conference Church-Acquisitions and Losses, $1995-2004 \ldots \ldots \ldots \ldots . \ldots 251$

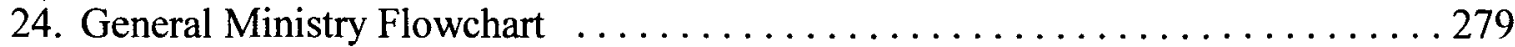


CHAPTER I

INTRODUCTION

\section{The Present Status}

A little more than one hundred years ago (1897) the Adventist message first set root in Icelandic soil but after an initial period of growth the church has remained stagnant with a membership of about 550 for decades with less than half of the membership being active. The church also has become distant from the general society and at present it faces loss of membership, financial difficulties, and a threat of having to further reduce its limited worker force.

\section{The Purpose of the Project}

The task of this dissertation is to propose a strategy of revitalization for the church by increasing its quality of church life, raising its self identity and sense of mission, and strengthening its ability to reach the community and to grow.

In light of the indications that the growth of the Seventh-day Adventist Church in Iceland has plateaued and that decline will soon set in, if it has not already, this condition needs to be investigated to determine its nature.

A previous dissertation has been written relating to church growth in Iceland. Even though this study is in many ways a valuable work in its dealing with the historical

${ }^{1}$ Steinthor B. Thordarson, "A Study of Factors Relating to the Numerical Growth of the Seventhday Adventist Church in Iceland from 1950 to 1980" (D.Min. dissertation, Andrews University, 1985). 
development of the church, it does not provide an adequate diagnosis of its present situation nor does it provide a strategy for the carrying out of an effective church program relevant to the present situation. This project will take into consideration the special needs and possibilities of the church and the society in which it operates and will seek to present a strategy to counteract the present trend of decline in church life and membership.

\section{Description of the Project}

The dissertation will review current literature on church growth and give special attention to the study conducted by the Institute of Church Development, located in Germany. This study covered 1,000 churches in 32 countries, and its findings were published by Christian A. Schwarz under the title, Natural Church Development: A Guide to Eight Essential Qualities of Healthy Churches.'

The basis for Adventist mission as found in Rev 14 will be examined in the context of the Great Commission of Matt 28:19-20 and attention will be given to the counsel given to the Adventist Church through Ellen G. White, particularly those writings that bear on church growth and mission strategy.

A historical overview of the development of the Seventh-day Adventist Church in Iceland will be established from available sources, and statistical and demographic information about the Seventh-day Adventist Church in Iceland will be gathered from the Iceland Conference, and an evaluation made of the growth of the church in Iceland. Further, an assessment of the present religious environment in Iceland will be done seeking to detect areas of receptivity to the gospel and to discover unmet societal needs

\footnotetext{
'Christian A. Schwarz, Natural Church Development: A Guide to Eight Essential Qualities of Healthy Churches (Carol Stream, IL: ChurchSmart Resources), 1996
} 
that could provide opportunities for the church to serve the people of Iceland.

On the basis of the foregoing information this project seeks to present an objective portrayal of the future possibilities of Adventist church growth in Iceland, develop a strategy for the revitalization of the church in Iceland, and to provide a practical mission strategy for the future work, useful to its leadership as well as its membership. 


\section{CHAPTER II}

\section{THEOLOGICAL FOUNDATIONS FOR A STRATEGY OF CHURCH GROWTH IN THE ADVENTIST CHURCHES IN ICELAND IN SCRIPTURE AND THE SPIRIT OF PROPHECY}

\section{Introduction}

The Adventist Church has a clear biblical vision of its special mission as God's messenger at the end of earth's history. It does also possess a rich legacy of counsel from God's messenger, Ellen G. White, relating to the nature, calling and the practical operation of the church. It is the purpose of this chapter, first, to present a biblical, theological foundation for the mission mandate of the Adventist Church and, second, to consult the counsel of Mrs. White with regard to the practical accomplishment of this God-appointed purpose of the church at this critical hour in history.

Foundational to the task of the church is the commission of Christ to his followers in Matt 28:18-20 to extend his mission to all the world: to go and make disciples, to baptize, and to teach. ${ }^{1}$ Every church that claims its foundation to be the early church of the New Testament must base its purpose and objectives on this commission. "Adventism professes to be a biblical movement, claiming that the Bible is their only rule

\footnotetext{
1"According to this passage, the mission of the church is to reach out to nonbelievers and develop them, along with existing believers, into committed followers of Christ. This is the mission the purposes of the church are intending to accomplish." James E. White, Rethinking the Church, rev. ed. (Grand Rapids, MI: Baker Books, 2003), 33.
} 
of faith and practice. If so, then Adventism must have a mission theology and practice that is fully in harmony with the New Testament model. If Adventism is not centered in the fulfillment of the Great Commission, its claim to be a New Testament church cannot be credible."1

But further, the Adventist Church, in contrast to the Christian church at large which finds its main mandate and motivation for world evangelization in the Great Commission, has drawn its mission impetus in equal measure from the urgency of the second coming expressed in Matt 24:14, the challenge of "preaching ... Christ's message to all the nations in order to hasten the advent of our Lord."2

And in particular, Adventists claim that the key to full understanding of the Adventist mission is found in Rev 14 where "all the elements of the two Matthean texts [are brought] together in one composite whole," ${ }^{, 3}$ and expounded in greater detail. In fact one can justly claim that Adventism looks towards the passage in Rev14:6-12 as its main mission mandate and that the Adventist Church sees the main purpose for its entering the scene of world history as being the proclamation of the everlasting gospel of Jesus Christ for the end time with a particular emphasis on the special messages of the three angels of Rev 14. Here it finds the task of preaching the gospel to all the world, that of making disciples, and the concept of the impending consummation of the world's history presented in a striking and compelling way.

It is the purpose in the first half of this chapter to, first, review the message of

\footnotetext{
${ }^{\text {I}}$ Russell Burrill, "Recovering an Adventist Approach to Life and Mission of the Local Church" (D.Min. dissertation, Fuller Theological Seminary, 1997), 56.

${ }^{2}$ Ibid., 57.

${ }^{3}$ Ibid., 60 .
} 
Rev14 in its wider context in the book of Revelation in order to discover the relationship between the call and charge presented in Revelation and the Great Commission especially as it is presented in Matt 28:18-20. Second, I will summarize Paul's portrayal of the missionary nature of the local church and its role in the fulfillment of the Gospel Commission as presented in Ephesians.

\title{
The Mission Mandate in the Great Commission
}

\author{
A Missionary Gospel
}

"All authority in heaven and earth has been given to me. Therefore go and make disciples of all nations, baptizing them in the name of the Father and of the Son and of the Holy Spirit, and teaching them to obey everything I have commanded you. And surely I will be with you always, to the very end of the age." (Matt 28:18-20)

This so-called "Great Commission" is viewed by most churches today as very central in planning and strategizing the fulfillment of their missionary responsibility and in recovering the evangelistic thrust. But while it is assumed by many that this has been the most powerful motivational text for Christian mission throughout the centuries, it has "in fact . . been demonstrated that this text was never used as the basis for missions until the time of William Cary."1

The disciples received this commission on an unknown mountain in Galilee where

\footnotetext{
${ }^{1}$ Mortimer Arias and Alan Johnson, The Great Commission: Biblical Models for Evangelism (Nashville: Abingdon Press, 1991), 13. "William Cary was the first to make inroads into the prevalent apathy about mission in his famous 'An Enquiry into the Obligations of Christians to Use Means for the Conversion of the Heathen' (1792). Cary's logic was simple: If the commission to make disciples of all nations were restricted to the apostles, then the command to baptize (Mt 28.19), and the promise of Christ's abiding presence (Mt 28.20), should also be subject to these limitations! Cary won the argument and large scale missionary enterprise was launched from Europe and North America." David Bosch, "The Structure of Mission: An Exposition of Matthew 28:16-20," in Exploring Church Growth, ed. Wilbert R. Shenk (Grand Rapids, MI: Eerdmans, 1987), 218.
} 
they had been summoned by Jesus. The gospel text mentions the Eleven as present at the occasion while Ellen G. White gives further insight: "At the time appointed, about five hundred believers weic collected in little knots on the mountainside, eager to learn all that could be learned from those who had seen Christ since His resurrection. . . . Suddenly Jesus stood among them.... His countenance was as the face of God, and when they saw Him, they worshiped Him."1

This occasion marked a transition of utmost importance in the salvific activity of Jesus Christ for humanity: "Christ's words on the mountainside were the announcement that His sacrifice in behalf of man was full and complete. The conditions of the atonement had been fulfilled; the work for which He came to this world had been accomplished. ... He had entered upon His mediatorial work. ${ }^{2}$

In the book The Great Commission: Biblical Models for Evangelism, Mortimer Arias, who sees the Great Commission as the fundamental paradigm for mission of the church, finds it essential to explore it in the context of the whole gospel. In Arias's mind the whole Gospel of Matthew, not only its conclusion, was written with missions in mind. It was written to a Christian community with staggering problems of identity and mission. $\mathrm{He}$ quotes Otto Michel who states: "Matthew 28:18-20 is the key to the understanding of the whole of Matthew's gospel. . . This pericope is the summary of the whole gospel."3

\footnotetext{
'Ellen G. White, The Desire of Ages (Mountain View, CA: Pacific Press, 1940), 818-819.

${ }^{2}$ Ibid., 819.

${ }^{3}$ Otto Michael, "The Conclusions of Matthew's Gospel," in The Interpretation of Matthew, ed. Graham N. Staton (Philadelphia: Fortress Press, 1983); quoted in Arias and Johnson, 17. "It was not until in the 1940s that biblical scholarship, pioneered by Michael and Lohmeyer, began to pay serious attention to Matthew 28:18-20. Since then there has been a sustained and, in fact, expanding interest among New Testament scholars in the closing lines on Matthew's gospel. . . Today scholars agree that the entire gospel points to these final verses: all the threads woven into the fabric of Matthew, from chapter 1 onward, draw together here. ... Our first gospel is essentially a missionary text. It was primarily because
} 
Arias then suggests five fundamental missiological questions, which are helpful in exploring the Great Commission in the context of the whole gospel: What is the method or strategy for mission? What is the content of the gospel? What is the motivation for mission? Who are the addressees? Who are the subjects of mission and evangelism? These missiological questions will here be summarized and compared with statements from Ellen G. White, where appropriate.

\section{The Method of Mission: The Making of Disciples}

As a method of mission Arias sees Matthew emphasize the didactic approach in educating and training disciples, indicating that Christian education should not be seen as a separate thing from evangelism. The whole Gospel is didactic in character and intention and has in fact been organized as a teaching text, and the last commission comes then as the climax of the didactic model. ${ }^{1}$

White concurs with this view: "In the commission to His disciples, Christ not only outlined their work, but gave them their message. Teach the people, He said, "to observe all things whatsoever I have commanded you." The disciples were to teach what Christ had taught. That which He had spoken, not only in person, but through all the prophets

of his missionary vision that Matthew set out to write his gospel, not to compose a "life of Jesus" but to provide guidance to a community in crisis on how it should understand its calling and mission." David Bosch, Transforming Mission: Paradigm Shifts in the Theology of Mission (Maryknoll, NY: Orbis Books, 1991), 57.

'Arias and Johnson, 18. "Make disciples (matheteusate) is the main verb and thus the focal point of Jesus' mission. 'Going,' 'baptizing,' and 'teaching' are parallel participles subordinate to 'make disciples.' These participles, which specify some of the actions involved in the overall task of making disciples take an imperative force since they are linked to the imperative verb, 'make disciples."' Donald A. Hogner, World Biblical Commentary: Matthew 14-28 (Dallas, TX: Word Books, 1995), 886. He thus concurs with Barth (Karl Barth, Church Dogmatics, 4. 3. b. [Edinburgh: T\&T Clark, 1966], 860). See also Virgil Gerber, God's Ways to Keep a Church Going and Growing (Glendale, CA: Regal Books, 1973), 14. 
and teachers of the Old Testament, is here included."

But discipleship, according to Matthew, goes beyond theoretical, doctrinal teaching and religious training. "Jesus' disciples were trained not only in othodoxy-the right doctrine-but also in othropraxis, the right way of doing and living and dying! ... Students of Matthew have found that structurally, thematically, and programmatically the last commission to the nations in $28: 16-20$ cannot be separated from the last judgment to the nations in 25:31-46."2

Concerning this White comments: "The gospel is to be presented, not as a lifeless theory, but as a living force to change the life. God desires that the receivers of His grace shall be witnesses to its power. ... He would have His servants bear testimony to the fact that through His grace men may possess Christlikeness of character, and may rejoice in the assurance of His great love." ${ }^{3}$ And further she says: "The wonderful love of Christ will melt and subdue hearts, when the mere reiteration of doctrines would accomplish nothing." ${ }^{14}$

The Content of Mission: The Gospel of the Kingdom

On the content of mission Matthew emphasizes the kingdom of God with its radical ethical demands and its christological center. But the antidote for legalism comes in the emphasis on personal relationship:

"The invitation to discipleship is not only to follow a Torah or an ethical system,

${ }^{1}$ White, Desire of Ages, 826.

${ }^{2}$ Arias and Johnson, 20.

${ }^{3}$ White, The Desire of Ages, 826.

${ }^{4}$ Ibid. 
but a personal promise and challenge: "Come unto me, all that are weary and are carrying heavy burdens, and $I$ will give you rest" $(11: 28) \ldots$ Mission is to teach his commandments. Christ is the omega-point of humanity, and the final criterion at Judgment Day will be our personal relationship with the Son of Man (25:31-46)."'

White also stresses that a christocentral emphasis is crucial in the proclamation of the church: "Tell the people of Him who is "the Chiefest among ten thousand," and the One 'altogether lovely.' The Song of Solomon 5:10, 16. Words alone cannot tell it. Let it be reflected in the character and manifested in the life. Christ is sitting for His portrait in every disciple."2

\section{The Motivation for Mission: The Experience of the Loving Lord}

What then is the motivation for mission presented in Matthew's Gospel? There is a clear rationale for mission in the authoritative command of the resurrected Lord: "All authority is given to me ... therefore go" (28:18). But Arias points to a motivation that is even stronger-the power of an inner motivation: "The inner motivation ... is not merely command, but an experience that issues out in mission..$^{3}$ This inner motivation is cultivated and springs from the context of worship: "When they saw him, they worshiped him" (28:17). They heard the mission charge in the context of worship and rose to the challenge in the power of the Holy Spirit. The reassurance of the experience of the living

\footnotetext{
'Arias and Johnson, 26. Bruner emphasizes the personal nature of the call: "The Great Com-
} mission has a sandwich structure: before and after the Mission Commands are the one and the same Mission Commander, like this: Mission Commander (I, Jesus, am in charge around here), Mission Command (So you move out, obeying me), Mission Commander (I, Jesus, will support you all the way-relax and enjoy!)." F. D. Bruner, Matthew, Volume II, The Churchbook (Dallas, TX: Word Publishing, 1990), 1089.

\footnotetext{
${ }^{2}$ White, Desire of Ages, 827.

${ }^{3}$ Arias and Johnson, 27.
} 
presence and the power of the crucified Lord becomes a source of joy, power, and missionary fervor which no opposition can quench.

But the love and compassion tor people which characterized Jesus' ministry must also be ours: "When he saw the crowds, he had compassion for them, because they were harassed and helpless, like sheep without a shepherd" (9:36). Arias quotes Raymond Fung who reminds us that our "evangelism anthropology has seen human beings exclusively as "sinners," while Jesus saw them not only as "sinners" but also as "the sinned against." Men and women are not only violators of God's law, they are also the violated."'

White has the following comment to make: "The first disciples went forth preaching the word. They revealed Christ in their lives. They did not ask for a blessing for themselves merely; they were weighted with the burden for the salvation of souls."2

The Addressees of Mission: The Nations and the Little Ones

Arias sees the addressees of mission introduced in Matthew's gospel to be the nations and the little ones. In spite of Jesus' apparent rejection by the world he assigns to his followers the whole world as their mission territory. "Jesus' own rejection was to become an inspiration and model for mission; the destruction of Jerusalem was not going to be the end of missions, but rather the beginning of missions to the whole world." ${ }^{3}$

Further attention to the addressees in Matthew will reveal the particular priority assigned to the "little ones": the poor, the children, the simple ones, etc.: "Globalization is

\footnotetext{
${ }^{1}$ Ibid., 29.

${ }^{2}$ White, 827.

${ }^{3}$ Arias and Johnson, 29.
} 
inseparable from contextualization. The "little ones," in the strange strategy of Jesus, became not only the objects but also the subjects of mission!"'

White notes concerning this: "Christ commissioned His disciples to proclaim a faith and worship that would have in it nothing of caste or country, a faith that would be adapted to all peoples, all nations, all classes of men."

The Subjects of Mission: A Church of Disciples

Finally, who are the subjects of mission? "The Saviour's commission to the disciples included all the believers. It includes all believers in Christ to the end of time." ${ }^{3}$

The disciples on the mountain represented the "appointed" covenant community of the Lord, all his followers, the ekklesia (only thus called in this Gospel). A test of true aspostolicity in the context of the "Great Commission" in Matthew is the faithful participation in making disciples for the kingdom, "teaching them to obey all that I have commanded you" (vs. 20).

But the church taking on this monumental task is not a perfect church. There are "weeds" among the "wheat" (13:24-30); there are hypocrites and false prophets (7:15; 24:11); many were falling away and betraying each other (24:10); there were false messiahs (24:24); the love of many was growing cold (24:12). This notwithstanding, this community fulfilled its mission in its time through and by the grace of God. "Both the charge and the promise are ours to assume and to claim."

\footnotetext{
'Ibid., 32.

${ }^{2}$ White, The Desire of Ages, 820.

${ }^{3}$ Ibid., 822.

${ }^{4}$ Arias and Johnson, 32-34.
} 


\section{The Great Commission in the Other Gospels}

Arias sees also the Great Commission in the other Gospels as arising from the real context of the churches and their mission in the second half of the first century and thus they do not merely contain the Great Commission but are in themselves a mandate, a call to mission. But each Gospel proclaims the coming kingdom of God with its own emphasis.

In Mark, the Gospel of action, the kingdom of God is proclaimed with power as an attack on the principalities and powers of Satan: "Go into all the world and preach the good news to all creation" (Mark 16:15). In the thirteenth chapter in Mark the Great Commission can be seen in its own right in an apocalyptic setting where the center of mission is to proclaim and to watch, the object of mission is the whole world, and the hope and motivation for mission is the hastening of the consummation of the kingdom (Mark 13:19).

In Luke's Gospel, the reading of the Scriptures is the main source of mission (Luke $4: 21 ; 24: 25-27,44-45)$, and the motif for mission is the jubilee arising from the Old Testament concept. This emphasis is first to be found in Jesus' inaugural speech in Nazareth (Luke 4:18-19) which became the foundation for His liberating, healing, and empowering mission. Thus the task of Jesus' followers is to invite all peoples into the jubilee of forgiveness, release, and liberation: "Then he opened their minds so they could understand the Scriptures. He told them, "This is what is written: The Christ will suffer and rise from the dead on the third day, and repentance and forgiveness will be preached in his name to all nations, beginning in Jerusalem. You are witnesses of these things" (Luke 24:45-47). 
In John's Gospel the experience of the resurrected Lord, the divine presence of the eternal Christ, motivated the disciples to share the message of peace and joy with the world. Arias sees this as an important theme in the gospel: The Christ who was the "Word [who] became flesh and lived a while among us" (John 1:14) is the one who, after the resurrection, came and "stood among them" (20:19), which made the otherwise fearful and disheartened disciples "overjoyed" (vs. 20).

The relationship revealed in the incarnation of God among men in Jesus Christ was then passed on as the content of mission for Christ's followers: "As the father has sent me, I am sending you" (vs. 21). This form of the Great Commission is the most crucial of all, in the opinion of John R. W. Stott, "and the most neglected because it is the most costly."'

\section{Exegetical Study of Revelation 14}

The Importance of Revelation 14 in the Adventist Context

The Advent movement was born within the environment of the study of apocalyptic prophecy with particular emphasis on Daniel and Revelation and within the fourteenth chapter of Revelation the movement has found basis for its identity and a reason for its existence. Late in her career Ellen G. White advocated an ongoing study of this chapter as she recognized that its full significance was not yet grasped: "The fourteenth chapter of Revelation is a chapter of the deepest interest. This scripture will soon be understood in all its bearings, and the messages given to John the revelator will be repeated with distinct utterance." ${ }^{2}$ The importance of Rev 14 in the Adventist setting can

\footnotetext{
'John R. W. Stott, quoted in Arias and Johnson, 79.

2“"Ellen G. White Comments-Revelation," SDA Bible Commentary, ed. F. D. Nichol (Washington, DC: Review and Herald Pub. Assn., 1953-57), 7:978.
} 
thus scarcely be over-emphasized.

This chapter can be seen as divided into two main parts which are again divided in two: Vss. 1-13 containing the vision of the triumphant church (vss. 1-5) and the messages of the three angels (vss. 6-13), and vss. 14-20, describing harvest scene or the second coming of Christ, first in terms of the wheat harvest (vss. 14-16), and second, the grape harvest (vss. 17-20).

The part of this chapter that is of particular interest for this present study is the vss. 1-13 which I will now attempt to analyze.

\section{Outline of Verses 1-5}

Then I looked, and there before me was the Lamb, standing on Mount Zion, and with him 144.000 who had his name and his Father's name written on their foreheads. And I heard a sound from heaven like the roar of rushing waters and like a loud peal of thunder. The sound I heard was like that of harpists playing their harps. And they sang a new song before the throne and before the four living creatures and the elders. No one could learn the song except the 144.000 who had been redeemed from the earth. These are those who did not defile themselves with women, for they kept themselves pure. They follow the Lamb wherever he goes. They were purchased from among men and offered as firstfruits to God and the Lamb. No lie was found in their mouths; they are blameless (Rev 14:1-5).

A picture is here drawn up of a group of 144,000 gathered on Mount Zion together with the Lamb. This is a vision of the triumphant church, the final generation of Christian believers, that survived the final threats of the antichrist,' and their character and the source of their strength are here described.

"Mount Zion" served in Israel's prophecies in the Old Testament as a symbol of the city of Jerusalem and its temple (see Ps 48:1, 2; Isa 40-66; Zech 1-9). "In Revelation,

${ }^{1}$ See Hans LaRondelle, How to Understand the End-Time Prophecies of the Bible (Sarasota, FL: First Impressions, 1997), 321-322. LaRondelle sees Rev 14 as a counterpart of Rev 13 with its description of the persecuting antichrist power. In the fourteenth chapter "the saints that endure the brunt of the antichrist powers receive a glorious reward for their faithfulness" (321). 
Mount Zion serves as a name for New Jerusalem and God's throne."' The 144,000, also described in Rev 7, are the end-time saints, the true "Israelites" from all tribes (12x12,000), wearing the Lamb's name and His Father's name on their foreheads. "Their 'sealing' as 'servants' of God marks them as those who have stood the test of the antichrist by rejecting his 'mark.' They are victorious, however, only because of their trust 'in the blood of the Lamb"' $(\operatorname{Rev} 7: 14){ }^{2}$

These tested and true followers "sing a new song" (vs. 3) before the elders and the four living creatures. They are obviously here participating in heavenly worship in which these heavenly creatures are continuously engaged $(\operatorname{Rev} 4-5 ; 11)$. This is reminiscent of the "new song" of the twenty-four elders before the throne where they praised the Lamb for His sacrificial death by which He "purchased men for God from every tribe and language and people and nation" (Rev 5:9-10) and the subject matter of their song is undoubtedly the same. The deep experience of intimacy of this group with Christ is portrayed in the words: "No one could learn the song except the 144,000 who had been redeemed from the earth" (vs. 3).

"They sing a new song before the throne, a song which no man can learn save the hundred and forty-four thousand. It is the song of Moses and the Lamb - a song of deliverance. None but the hundred and forty-four thousand can learn that song; for it is the song of their experience - an experience such as no other company have ever had."

Thus the content of their song, their mission, issues forth from the context of

\footnotetext{
${ }^{1}$ C. Mervyn Maxwell, God Cares, 2 vols. (Boise, ID: Pacific Press, 1985), 2:349.

${ }^{2}$ LaRondelle, 325.

${ }^{3}$ Ellen G. White, The Great Controversy (Mountain View, CA: Pacific Press, 1939), 649.
} 
worship, their motivation for mission.

This group is further described as not having "defiled themselves with women," they "follow the Lamb wherever he goes," are "purchased from among men," "offered as firstfruits," "no lie was found in their mouth," that is "they are blameless" (vss. 4-5). This is to say that this company does not "follow the fallen 'women' of apostate-worship communities, later called Babylon or 'the mother of prostitutes' (Rev 17:5). They follow the Lamb of God exclusively."1 Their experience can be compared with the experience of Enoch because they also "walk with God" and will be taken away without experiencing death. They are the end-time Elijahs because they stand courageously against the powerful end-time Baals and will be "taken" by chariots of salvation and translated into glory ( 2 Kgs 2:10, 11; Rev 19:14). ${ }^{2}$

They are a "first fruit" sacrifice (vs. 4) in the sense of being the first in quality, the finest of the harvest. The declaration of "blamelessness" (vs. 5) must be understood, according to LaRondelle, in the context of a parallel description in Zeph 3:13: "To understand this characterization of the 144,000 adequately, we must first probe its meaning in Zephaniah 3. This Old Testament prophet does not apply Israel's blamelessness and "perfection" in an abstract way, but to her worship of the LORD through obedience to His covenant law free from the lies of idol worship, false miracles, and false prophecy."

All this implies that the end-time 144,000 , through their sealing and as the end-

\footnotetext{
${ }^{1}$ LaRondelle, 326.

${ }^{2}$ Ibid., 328.

${ }^{3}$ Ibid., 326.
} 
time firstfruits, are "purchased from the earth" as the beginning of the world harvest described in Rev 14:14-16.

\section{Outline of Verses 6-13}

\section{Verses 6-7: The First Angel}

Then I saw another angel flying in midair, and he had the eternal gospel to proclaim to those who live on the earth-to every nation, tribe, language and people. He said in a loud voice, "Fear God and give him glory, because the hour of his judgment has come. Worship him who made the heavens, the earth, the sea and the springs of water" (Rev 14:6-7).

"Another angel"

Though some commentators attach "no particular significance" to the phrase "another angel" others assign special meaning to it and to some the connection they see between this angel and the "mighty angel" mentioned in the tenth chapter becomes an interpretive key to the significance of the three angels of the fourteenth chapter.

LaRondelle compares them thus: "The threefold message of Rev. 14 apparently functions as the expansion of the mission of the "mighty angel" during the sixth trumpet (Rev 10:5-7). In both chapters 10 and 14 the end-time warning from heaven is intended for the entire earth. The angels "flying in mid-air" (the zenith of the sky) in Rev 14 symbolizes the worldwide reach of its message."2

This is in accordance with the view of Ellen G. White: "The message of Revelation 14, proclaiming that the hour of God's judgment is come, is given in the time of the end;

'R. H. Mounce, The Book of Revelation, The New International Commentary on the New Testament (Grand Rapids, MI: Eerdmans, 1977), 272. See also Seventh-day Adventist Bible Commentary, 7:827, comment on Rev 14:6, "Another."

${ }^{2}$ LaRondelle, 329. 
and the angel of Revelation 10 is represented as having one foot on the sea and one foot on the land, showing that the message will be carried to distant lands, the ocean will be crossed, and the islands of the sea will hear the proclamation of the last message of warning to our world."1

The angel in chap. 10 declares that "there will be no more delay" (10:6). In White's view "this message announces the end of the prophetic periods" declared by the prophet Daniel and this is in fact in a nutshell, according to LaRondelle, the "end-time message that is further unpacked" by the angels in the fourteenth chapter. ${ }^{3}$

\section{"Eternal gospel"}

The first angel thus enters the scene to proclaim the "eternal gospel" at the final stage of earth's history. It pictures an escalated, powerful, universal proclamation of the Good News of salvation in Jesus Christ at that late hour and ties in with Jesus' prediction that "this gospel of the kingdom will be preached in the whole world as a testimony to all nations, and then the end will come" (Matt 24:14). Rev 10 and 14:6-12 thus describe the implementation of Jesus' prediction in Matt 24:14 and Mark 13:10.

This gospel which the angel brings must be the apostolic gospel summarized thus by Paul: "For what I received I also passed on to you ... that Christ died for our sins ... that he was buried, that he was raised on the third day" (1 Cor 15:3-5). Any other gospel would have called for passionate protest. But in the context of the closing events of

\footnotetext{
'Ellen G. White, Selected Messages, 3 vols. (Washington, DC: Review and Herald Pub. Assn., 1959), 2:107-108.

${ }^{2}$ Ibid., 108.

${ }^{3}$ LaRondelle, 328.
} 
human history a new grasp of the apostolic gospel creates a remnant people as the church carries out its final mission which is a repetition and an intensification of the appeal of Jesus: "Repent, for the kingdom of heaven is near" (Matt 4:17).

"Worship God as Creator"

The first angel calls with a "loud voice," underlining the urgency of his message, and calls all people to worship God as creator: "him who made the heavens, and the earth and the springs of water" (14:7).

This clearly reminds one of the reasoning presented in Exod 20:11 for the call of the Israelites to worship God on the weekly Sabbath: "For in six days the Lord made the heavens and the earth, the sea, and all that is in them, but he rested on the seventh day. Therefore the Lord blessed the Sabbath day and made it holy."

In Deuteronomy the reasoning for remembering and observing the Sabbath is the liberation of the nation from the enslavement in Egypt: "Remember that you were slaves in Egypt and that the Lord your God brought you out of there with a mighty hand and an outstretched arm" (Deut 5:15). But this redemptive, gracious initiative on God's part, must also be seen as a creative act as he forms his covenant people: "When Israel was a child, I loved him, and out of Egypt I called my son" (Hos 11:1).

Likewise the redemptive acts of God through Jesus Christ in raising up his Church are acts of creation and were thus understood by Paul:

Because of his great love for us, God, who is rich in mercy, made us alive with Christ even when we were dead in transgressions-it is by grace you have been saved. And God raised us up with Christ and seated us in heavenly realms in Christ Jesus (Eph 2:4-6).

For he has rescued us from the dominion of darkness and brought us into the kingdom of the Son he loves, in whom we have redemption, the forgiveness of sins (Col 1:13). So that, just as sin reigns in death, so also grace might reign through righteousness to 
bring eternal life through Jesus Christ our Lord (Rom 5:21, emphasis supplied).

The response to the call of the first angel to worship God as creator is thus "implied in the continuity if God's covenant between Israel and the Church: by honoring the seventh-day Sabbath as the 'blessed' memorial of the creative and redemptive work of the covenant God of Israel."

One may ask what practical implications the heeding of the angel's message will have for those who listen, and in what way his call does meet a present need. Or, in other words, why does the angel bring this matter to the attention of all nations at this point in time? Here, it seems, is something that always has been true and valid (a part of the eternal gospel), but which needs to be greatly emphasized in the light of the present situation.

This becomes clearer when these verses are contrasted with chap. 13 where the beast seeks to coerce humanity to worship him or else suffer persecution or death: "He exercised all the authority of the first beast on his behalf, and made the earth and its inhabitants worship the first beast, whose fatal wound had been healed. ... He was given power to give breath to the image of the first beast, so that it could speak and cause all who refused to worship the image to be killed" $(\operatorname{Rev} 13: 12,15)$.

As a contrast to this the gracious invitation to worship God is presented in the fourteenth chapter.

In light of this struggle it becomes clear that obedience to the call of the first angel becomes a test of loyalty: Whom will man follow, the true creator and sustainer of the universe or the arch deceiver and usurper?

'LaRondelle, 333. 
But another purpose, related to this, is accomplished by heeding the call. The great need for protection and divine intervention on behalf of those who choose to thwart the oppressive claims of Sätan is met here. Here protection is provided for those, who, during earth's final hour, will be the object of the full force of Satan's power to deceive and persecute.

Under these extreme circumstances the Sabbath will be the haven and refuge it was at the inception of human history. White wrote: "If man had always observed the Sabbath, there would never have been an unbeliever, and infidel, or an atheist in the world. If Adam and Eve ... had considered the reason that God had in giving them the Sabbath ... they would have been safe. . . If they had considered how he had made them the object of his overflowing love, they would not have fallen; but they forgot the presence of God."'

This call to worship and the identification of the true worshipers of God is regarded by many commentators as a central theme in the book of Revelation. This points to the fact that the purpose and function of this call is described in the fourteenth chapter in code only, so to speak. The full import of this call will be understood only through a study of the book in its entirety.

Concerning the general theme of the book of Revelation White comments:

[In the book of Revelation] Christ is spoken of as walking in the midst of the golden candlesticks. Thus is symbolized His relation to the churches. He is in constant communication with His people. He knows their true state. . . Christ is represented as holding the seven stars in His right hand. This assures us that no church faithful to its trust need fear coming to nought, for not a star that has the protection of Omnipotence can be plucked out of the hand of Christ. ... In comparison with the millions of the world, God's people will be, as they have ever been, a little flock; but if they stand for the truth as revealed in His word, God will be their refuge. They stand under the broad

'Ellen G. White, “The Test of Loyalty," Signs of the Times, February 13, 1896, 7. 
shield of Omnipotence. God is always a majority. ${ }^{1}$

It was through one who declared himself to be a "brother, and companion in tribulation" (Revelation 1:9), that Christ revealed to His church the things that they must suffer for His sake. Looking down through long centuries of darkness and superstition, the aged exile saw multitudes suffering martyrdom because of their love for the truth. But he saw also that He who sustained His early witnesses would not forsake His faithful followers during the centuries of persecution that they must pass through before the close of time. ${ }^{2}$

One thing will certainly be understood from the study of Revelation-that the connection between God and His people is close and decided. ${ }^{3}$

In Ellen White's mind, this theme of personal and assured relationship through the redemptive work of Christ is the central one in Revelation, and parallels the chief purpose of the Sabbath, as shown above. Further quotations will emphasize this: "The Sabbath is a golden clasp that unites God and His people."4 "To all who receive the Sabbath as a sign of Christ's creative and redeeming power, it will be a delight. The Sabbath points them to the works of creation as an evidence of His mighty power in redemption. While it calls to mind the lost peace of Eden, it tells of peace restored through the Saviour. And every object in nature repeats His invitation, 'Come unto Me, all ye that labor and are heavyladen, and I will give you rest.' Matt. 11:28."

Quite appropriately, then, the vision recorded in the book of Revelation was revealed to John on the Lord's Day, the Sabbath. Again White comments: "On the Sabbath the risen Saviour made His presence known to John. . . He was permitted again

${ }^{1}$ Ellen G. White, Acts of the Apostles (Mountain View, CA: Pacific Press, 1911), 586.

${ }^{2}$ lbid., 588 .

${ }^{3}$ Ellen G. White, The Faith I Live By (Washington, DC: Review and Herald, 1958), 345. $6: 351$.

${ }^{4}$ Ellen G. White, Testimonies for the Church, 9 vols. (Mountain View, CA: Pacific Press, 1948),

${ }^{5}$ Ellen G. White, Desire of Ages, 289. 
to behold his risen Lord, clothed with as much glory as a human being could behold, and live. What a Sabbath was that to the lonely exile, always precious in the sight of Christ, but now more than ever exalted!"’1

"The hour of His judgment has come"

LaRondelle describes how commentators have applied this statement in two ways. First, it aptly relates to the coming judgment described in the latter part of the chapter in terms of the twofold harvest, the gathering of the righteous, the wheat harvest, and the destruction of those who have rejected God's saving grace, the grape harvest. This would then be God's executive judgment: "In this view, the first angel announces the coming judgment at the second coming of Christ portrayed in the subsequent vision (14:14-20). This view interprets "the hour of God's judgment" as the execution of judgment at the second coming."2

A second view connects this vision with Dan 7 where a court session is described as taking place in heaven. At the conclusion of this court session "one like a son of man" would come "with the clouds" to receive the dominion over this world (Dan 7:13, 14). As a connecting link between these visions LaRondelle points out: "Even the phrase "One like a son of man' in Rev. 14:14 is adopted directly from Dan. 7:13 and not from the Gospels. This indicates that John specifically had Dan. 7 in mind when he wrote the judgment visions of Rev. 14."

This is a description of the Adventist doctrine of the so-called pre-advent judgment

\footnotetext{
1"Ellen G. White Comments-Revelation," 7:955.

${ }^{2}$ LaRondelle, 338.

${ }^{3}$ Ibid.
} 
in a heavenly court: "The saints maligned and condemned by the nefarious [little] horn, enter the judgment for vindication: "The Ancient of Days . . pronounced judgment in favor of the saints of the Most High, and the time came when they possessed the kingdom" (Dan. $7: 22$ ). How reassuring to the suffering saints is the prospect of this vindicating judgment!"'

In Adventism the meaning of the phrase "the hour of his judgment has come" Rev 14:7 announces the initiation of God's pre-advent judgment in the heavenly courtroom, and when in church history this message was activated it announced that the final phase of salvation history had arrived. "This new event in heaven must be proclaimed on earth!"2

\section{Verse 8: The Second Angel}

A second angel followed and said, "Fallen! Fallen is Babylon the Great, which made all the nations drink the maddening wine of her adulteries ( $\operatorname{Rev} 14: 8$ ).

\section{"Babylon the Great"}

Here is introduced a collapse of an entity described by a code which can only be understood by referring to Israel's history in the Old Testament. In the writings of the Old Testament prophets, Babylon is the great arch enemy and persecutor of Israel, the one who even sets herself up against God himself, and whose downfall is predicted (Isa 21; Jer 50, 51). This also is the case in Revelation where Babylon symbolizes a power of religious character which can be identified with the power described in Rev 13, and which also is identical with the "little horn" and the "king of the North" in the book of Daniel. Thus the name is chosen in order to show a connection with Israel's old enemy through type and

\footnotetext{
'Ibid., 339.

${ }^{2}$ Ibid.
} 
antitype during the old covenant. "So just as ancient Babylon was the persecutor of Israel, so "Babylon" in Revelation is the persecutor of Israel of God in the time of the end. ... From the start the essential characteristic of Babel (lit. "gate of the gods") has been to climb up to the heavens in order to usurp the place and the ruling power of God... [Its] basic intention is to represent God on earth "according to his own will" (Dan 11:36 KJV). This is the power that wages war against the Lamb and his saints and seeks to usurp the High Priest's position and power to forgive sins and decide about salvation. ${ }^{2}$

"The Maddening Wine"

Babylon's wine represents the spurious doctrine of her religious system: "The 'wine'of Babylon, by which all the nations of the earth have been intoxicated, apparently refers to Babylon's doctrinal teachings, by which she has corrupted the everlasting gospel and the commandments of God (see Rev 14:12)." When people drink this "wine," the fundamental distinction between the Creator and creation, between the holy and the profane, becomes blurred in the people's mind. The worshipers of the beast will honor the creature more than the Creator. This is the essence of idolatry. ${ }^{4}$

This is also the central issue in Satan's rebellion against God which through the Fall caused estrangement and breakdown of community between God and his creation. Thus the main purpose of the plan of salvation and the establishment of the church is the

'Ibid., 345, 346.

${ }^{2}$ J. B. Doukhan, Daniel: The Vision of the End (Berrien Springs, MI: Andrews University Press, 1987), 66; quoted in LaRondelle, 346.

${ }^{3}$ LaRondelle, 349.

${ }^{4}$ Ibid., 350 
restoration of community between God and his creation.

The three members of the Godhead-Father, Son, and Holy Spirit-are three separate persons but one in character, unity, and purpose. We do not understand the oneness of God apart from the plurality of that oneness. ... Adventists have sensed that God has called us to help restore people to the image of God. If that truly is our mission, then we must recognize that God's image cannot be restored unless humankind is relationally restored to live in community with each other just as do the Father, Son, and Holy Spirit.... That should place small groups that restore community at the very center of Adventist mission. ${ }^{1}$

"The essence of God is community. God Himself does not exist apart from community. At God's very heart and center is the whole idea of community. One cannot truly understand God apart from his existence in community."2

The Sabbath and community

The seventh-day Sabbath, instituted at creation, is the supreme symbol and causative agent of community between God and creation and between believers. "The original function of the Sabbath was not rest.... [Adam and Eve] were asked to cease from their work. Not for the sake of human rest, but for the purpose of entering into relationship with the infinite God of the universe." ${ }^{3}$

While fulfilling a need as a venue for personal relationship it also reminds us of Creator/creation and Savior/saved roles and is instrumental in individual salvation and the carrying out of saving acts. Thus Adventists have understood the successful attacks and removal of the observance of the Sabbath in the official church during the reign of Constantine in the fourth century to be a "babylonian" influence at work in church history.

'Russell Burrill, The Revolutionized Church of the $21^{\text {st }}$ Century (Fallbrook, CA: Hart Research Center, 1997), 20.

${ }^{2}$ Ibid.

${ }^{3}$ Ibid., 24, 25 . 
The institutional church

Second, the nationalization and gradual institutionalization of the church, also effectuated during Constantine's reign, had a dramatic influence in reducing the effectiveness of the church and must be seen as a beginning of its "Babylonian captivity." "With the conversion of Constantine in the early fourth century, Christianity began to be tolerated and then became the only religion of the empire. This was the turning point in the establishment of the institutional church and the demise of the small group church."1

The institutional church gradually blocked the direct access of the laity to God. A professional priesthood emerged who alone became responsible for the administration of the word, the sacraments, and the remission of sins while the laity were restricted from direct involvement in service. In this way the "Babylonian" power succeeded in tampering with the structure of the Body of Christ on earth and the official church changed from being a group of people who themselves were recipients of the indwelling Christ through the Spirit, which is the only necessary qualification and condition for a priestly role, "the priesthood of all believers," to an impersonal institution. This "Babylonian captivity" of the church spelled a gradual end to the small house, lay-led churches of the New Testament which had secured the nurture and participation of the whole membership: "Instead of the congregation being a small group that constituted the church in that place, the understanding of the congregation had been enlarged to include everything in the Empire. The congregation was the church, the church was the Empire." "Satam could not

$$
\text { 'Ibid., } 92 .
$$

${ }^{2}$ Gareth Icenogle, The Church in Ministry through Small Group Ministry: An Integrated Approach (Downers Grove, IL: Inter Varsity Press, 1993), 360-361 [includes quotation from Loren Mead, The Once and Future Church (New York, NY: Alban Institute, 1991), 15], quoted in Burrill, The Revolutionized Church of the $27^{\text {st }}$ Century, 93. 
have devised a more ingenious plan! First of all. He gave the church political sanction and social respectability. Then he set about to neutralize the church by attacking its small group structure. The church was thus limited in its ability to nurture new members, apply spiritual power, edify the body, train necessary leaders, deliver the gospel to the world, encounter the presence of the living Christ and walk in the gifts of the Spirit."

"Fallen, fallen is Babylon"

The main and abominable sin of Babylon, the usurper of the position of God, is that she has sought to obstruct people's access to the source of all life, God himself. The good news of the second angel is that this oppressive power has been defeated and its spell over God's people broken. A final obliteration of the enemy of God is in sight.

The great message of the fall of Babylon thus tells a story about the beginning release of God's people. The fall of the great oppressor of God's people signals the opening of the gate for the outpouring of the Spirit and great success in the building of God's kingdom, the spreading of the gospel message, and the preparation for the inauguration of the kingdom of glory.

The delivery of this message is a call to people "who will live in true community and thus demonstrate to the world the transforming nature of the community God has called into being." In this process the Sabbath is a key symbol and a causative agent of the worship called for by the first angel. The breaking loose of the power and purpose of

\footnotetext{
${ }^{1}$ William A. Beckham, The Second Reformation: Reshaping the Church for the $21^{\text {si }}$ Century (Houston, TX: Touch Publications, 1995), 43, 44.

${ }^{2}$ Burrill, The Revolutionized Church of the $21^{s t}$ Century, 156.
} 
God is tied up with the observance of this express command of God given in his holy law.

The prophet Isaiah describes true Sabbathkeeping in the chap. 58 as the secret of a close relationship with God:

Is not this the kind of fasting I have chosen: to loose the chains of injustice and untie the cords of the yoke, to set the oppressed free and break every yoke? Is it not to share your food with the hungry and to provide the poor wanderer with shelter-when you see the naked, to cloth him, and not turn away from your own flesh and blood? Then your light will break forth like the dawn, and your healing will quickly appear; then your righteousness will go before you, and the glory of the Lord will be your rear guard. Then you will call, and the Lord will answer; you will cry for help, and he will say: Here I am (Isa 58:6-9).

Thus true Sabbathkeeping will engage people in the task of being a blessing to their neighbor and also produce an encounter with the Lord of the church. Here in fact is a description of the true purpose of the church of Christ in the world. Ellen G. White comments on these verses: "The piety and advanced spiritual knowledge and growth of a church is proportional to the zeal, piety, and missionary intelligence that has been brought into it, and carried out of it to be a blessing to the very ones who need our assistance the most. . . I urge you to consider Isaiah 58 which opens a wide and extensive vineyard to be worked upon the lines which the Lord has pointed out."1

Here is a description of a church which engages in deep, personal relationship with those it encounters in the world, and which also encounters Christ in a personal, meaningful way. In order to engage in this work which is the work the Lord prescribed for his church on earth, we need to return to the church structure of the New Testament church of small, lay-led groups which maintained growth during the first centuries of Christendom even during the most difficult periods of severe persecution, and had secured

\footnotetext{
'."Ellen G. White Comments-Isaiah," SDA Bible Commentary, 4:1148.
} 
the nurture and participation of the whole membership:

To learn to trust, and to become trustworthy-to learn to live, and to become loving-we must become deeply involved in the lives of other, to whom we commit ourselves in Christ. To develop this kind of relationship, we need to share ourselves with others, and they need to share themselves with us. All of this demands time. More than this, it requires a face-to-face relationship. A relationship we can have only with a few others at one time. And thus a church is forced to move to a small group structure. ${ }^{1}$

\section{Verses 9-13: The Third Angel}

A third angel followed them and said in a loud voice: "If anyone worships the beast and his image and receives his mark on the forehead or on the hand, he, too, will drink of the wine of God's fury, which has been poured full strength into the cup of his wrath. He will be tormented with burning sulfur in the presence of the holy angels and the Lamb. And the smoke of their torment rises for ever and ever. There is no rest day or night for those that worship the beast and his image, or for anyone who receives the mark of his name." This calls for patient endurance on the part of the saints who obey God's commandments and remain faithful to Jesus. Then I heard a voice from heaven say, "Write: Blessed are the dead who die in the Lord from now on." "Yes," says the Spirit, "they will rest from their labors for their deeds will follow them" (Rev 14:9-13).

Here are spelled out terrible threats of retribution that will befall those who choose Babylon's poisonous wine instead of the pure water of life which Christ offers (John 4:10, 13,14). Only the partaking of the latter constitutes true worship "in spirit and in truth" (vs. 24).

The third angel informs us that those who consume Babylon's wine will have to drink the wine of God's wrath as well "which is poured out full strength" (vs. 10). "This cup of wrath is no longer mixed with mercy. It is poured out as the seven last plagues $(\operatorname{Rev} 15: 1) .{ }^{.2}$

LaRondelle further points out that this picture of the cup of God's wrath is central

'Lawrence Richards, quoted in John Mallison, Growing Christians in Small Groups (Sidney, Australia: Anzes Publishers, 1989), 9.

${ }^{2}$ LaRondelle, 352. 
to the gospel: "Jesus' acceptance of the cup of divine wrath from God's hand in Gethsemane belongs to the core of the gospel (Matt 20:22; 26:39, 42). E. W. Fudge states, "Because He accepted that cup, His people will not have to. The cup he leaves for us [the communion cup] is a constant reminder that He has taken our place" (Matt 26:27-29)."

\section{The Relationship Between the Great Commission and the Message of the Three Angels in Revelation 14}

The Missiological Questions Applied to Revelation 14:1-13

It is helpful, in order to examine the relationship between the mission emphasis of the gospel and the meaning of the verses being studied in Rev 14, to apply the five missiological questions of method, content, motivation, addressees, and subjects of mission to the text in Revelation.

\section{The Method of Mission}

If the method of mission in Matthew is discipleship this also is the method in Rev

14. Burrill comments: "Like Matthew's Great Commission, the object of the three angels' messages is to produce a people who keep the commandments of God". 2

Burrill then goes on to state that the 144,000 described in Rev.14:1-5 are true disciples who have, as a result of the proclamation of the messages of the three angels, stood the severe test of the attacks of Satan: "In Adventist understanding, the 144,000 ... represent the people who are ready to meet Jesus at the time of the Second Advent. They are the new spiritual Israel.... Adventists understand that the preaching of the thee ibid., 351-352.

'E. W. Fudge, The Fire That Consumes (Fallbrook, CA: Verdict Publications, 1982), 296, quoting

${ }^{2}$ Burrill, "Recovering an Adventist Approach to Life and Mission of the Local Church," 60. 
angels' messages is meant to produce the people who are described in these verses.

Therefore the goal of Adventist mission is to not just proclaim a message, but to produce these people whom the number 144,000 symbolize as complete."'

\section{The Content of Mission}

If the above is the case, the description of the 144,000 sealed ones standing on Mount Zion will describe also the content of the gospel proclaimed by the messengers in vss. 6-13.

Burrill ${ }^{2}$ summarizes their characteristics in the following way:

1. They wear their Father's name-They live in full commitment to God.

2. They have been redeemed-They have been purchased by the blood of Calvary.

3. They possess pure faith-They have rejected the poisonous wine of Babylon and have kept the pure faith of Jesus.

4. They follow Jesus all the way-Turning away from the beast and its image, these have not only been taught, but follow all that Jesus commanded. This also demonstrates the close and intimate relationship between these followers and Christ advocated by the first angel (see above), and it reminds us of the similar emphasis in John's Gospel, also noted above.

5. They stand without fault, they are blameless before God-These have been covered by Christ's righteousness, and have thus passed the judgment and are ready to meet Jesus and enter heaven.

These five characteristics of those who have heeded the gospel preached during the

${ }^{\mathrm{I}}$ Ibid., 62.

${ }^{2}$ Ibid. 
time of the three messengers' proclamation are reminiscent of the characteristics of true disciples as Jesus enumerated them in the Gospels. In fact, everything that the Great Commission specifies is here enumerated in greater detail.

\section{Motivation for Mission}

The main motivation for mission here is the great urgency also expressed in Matthew and Mark: "And this gospel of the kingdom will be preached in the whole world as a testimony to all nations, and then the end will come" (Matt 24:14). "And the gospel must first be preached to all nations" (Mark 13:10).

This special message of the eternal gospel must be proclaimed in view of the imminence of the parousia. A tremendous intensification of the message in the apocalyptic warnings of the third angel is used to give necessary urgency to the task of preparing a people who keep the commandments of God and remain faithful to Jesus.

\section{The Addressees of Mission}

While the addressees mentioned in Matthew and Luke are "all nations," and in Mark "all creation," the urgency of the proclamation of the three messengers is emphasized and elaborated by the use of the formula: "Every nation, tribe, language and people" (Rev 14:6). William Barclay comments: "The angel comes with the message of the gospel to all races and tribes and tongues and peoples. The earth is to be given a final opportunity to accept or to reject Jesus Christ."'

\footnotetext{
'William Barclay, Revelation of John, 2 vols. (Edinburgh: Saint Andrews Press, 1974), 2:143.
} 


\section{The Subjects of Mission}

As opposed to the human instrumentalities secured for the carrying out of the mission task in the giving of the Great Commission in the Gospels, the last warning message, it seems, is portrayed as being proclaimed by angelic beings. But Ellen G. White sees these as symbolic representation: "Christ is coming the second time, with power unto salvation. To prepare human beings for this event, He has sent the first, second, and third angels' messages. These angels represent those who receive the truth, and with power open the gospel to the world."

This indicates that the company described in Rev 14:1-5, who are the recipients of the final gospel proclamation and who have personally experienced Christ's "power unto salvation," are the ones who offer the world this final opportunity to accept Jesus' gracious gift of eternal life.

The Centrality of the Cross

It has been suggested in this study that the Great Commission in Matt 28:18-20 empowers the Christian church to continue Christ's mission to call people to full obedience to his teachings contained in the whole gospel account of Matthew. In this Gospel we are in a powerful way confronted with a message about the nearness of the kingdom of God and a call for humanity to take a stand for or against God's gracious initiative. It contains the whole account of the saving activity of God through Jesus Christ, his life and ministry, death, resurrection, ascension to heaven, and the judgment and his second coming.

1"Ellen G. White Comments-Revelation," 7:979. 
Further more, the Great Commission in Matthew, cradled as it is in the gospel account, places great emphasis on discipleship. Citizenship in the kingdom, as portrayed in the Sermon on the Mount, demands full commitment to a high spiritual and moral standard: “There is no room in Matthew's version of Jesus' teachings for soteriology, or eschatology for that matter, without ethics. No room for "cheap grace"! To announce a gospel that is not proclaiming and demanding this "higher justice" and that ignores or postpones the highest priority of love in God's action and human life is a serious departure from the "Great Commission," which sends us back to "everything Jesus commanded."

It is this same gospel that the angels in Rev 14:6-13 proclaim. Nothing can ever be added or subtracted from this gospel without distorting and perverting it. Thus Adventists, basing their mission on this passage, must understand it against the background of the Great Commission. Burrill comments: "Revelation 14 must be seen as an extension of John's commentary on the Great Commission as it is to be carried out in the last days of human history. The goal of the three angels' messages is identical to the goal of the Great Commission. That goal is the making of disciples who keep the commandments of God and remain faithful to Jesus."

But there exists a danger among Adventists in focusing unilaterally on the elements most conspicuous in this passage which have given rise to the unique doctrines in Adventism, the Sabbath, heavenly ministry of Christ and the pre-advent judgment and the second coming. There is no doubt that these doctrines are glorious jewels that must be presented as present truth for the end time. But the foundation must never be lost sight of:

\footnotetext{
${ }^{1}$ Arias and Johnson, 25.

${ }^{2}$ Burrill, "Recovering an Adventist Approach to Life and Mission of the Local Church," 60.
} 
The cross of Christ. There is a need for these doctrines to be kept in a creative tension with the fundamental truth of Christianity, the saving act of Jesus Christ on Calvary. David Newman sounds this note in the context of a discussion about Adventist worship: "While the unique doctrines of Adventism [the Sabbath, the heavenly ministry of Christ, and the second coming] do have their place, we must be careful not to replace the cross as the fulcrum on which worship rests. While Jesus' ministry in the heavenly sanctuary is important, it would have no significance if he had not died for us. Without the cross the Second Coming would be a hollow mockery, and without the cross, why would anyone want to keep the Sabbath?"'

Surely, the only valid foundation for the Adventist mission is the proclamation of salvation by faith in Jesus Christ and surely it is based on Christ's sacrifice and the ministry of the Holy Spirit who produces a people who keep the commandments of God and remain faithful to Jesus. But as great emphasis is placed on faithfulness in observance and preparedness for the summing up of human history, the constant danger exists that the church's focus starts to shift toward the guarding of its own achievements. The church must vigorously guard against the presentation of the mission of the church in a light that to some extent carries with it an emphasis on human preparedness for the second coming and subtracts from the only true source of readiness: The sanctifying work of Christ and God's covenant faithfulness towards his people.

Thus the end-time Adventist proclamation, with its richness in doctrinal insight, must never see the messages of the three angels as coming in lieu of, or even in addition to, but rather as a result of the gospel proclamation in its verity. It must never lose sight of

'J. David Newman, "The Cross, the Center of Worship," Ministry, October 1991, 4. 
the fact that it is the miracle of the gospel which performs the transformation of a sinner to a saint and prepares him or her for eternity. In the words of White: "Christ crucified-talk it, pray it, sing it, and it will break and win hearts. This is the power and wisdom of God to gather souls for Christ."

\section{The Missionary Role of the Church in Ephesians}

The best source of information on Paul's view on the church and its function is his letter to the Ephesians. It is here Paul has much to say about the place of the church in God's plan to bring about unity in the world. As Barclay comments: "It is here that Paul strikes out one of his greatest phrases. The Church is the Body of Christ. The Church is to be hands to do Christ's work, feet to run upon His errands, a mouth to speak for Him, an instrument, a body through which he can work.".2

In order to discern the meaning of Paul's message it is useful to analyze the principal statement he uses to describe the church, as Van Engen points out in his book God's Missionary People: "A careful analysis of the images of the Church in Ephesians can be particularly helpful for understanding Paul's view of the Church's mission." I will I now, in the following pages, seek to summarize Paul's teaching on the role and function of local church in mission on the basis of such and analysis. ${ }^{4}$

'Ellen G. White, Sons and Daughters of God (Washington, DC: Review and Herald, 1955), 221.

${ }^{2}$ William Barclay, The Letter to the Ephesians, The Daily Study Bible, vol. 10 (Edinburgh: Saint Andrews Press, 1974), 79.

${ }^{3}$ Charles Van Engen, God's Missionary People: Rethinking the Purpose of the Local Church (Grand Rapids, MI: Baker Book House, 1995), 48.

${ }^{4}$ In this analysis material is used from the third chapter of Van Engen's above mentioned book. 
The most prominent word for the church in the New Testament is ekklesia, ' with the connotation of an assembly-either a gathering or the individuals gathered-being called or summoned out ${ }^{2}$ but in Ephësians many other word images are used just as frequently to denote the church. This, concludes Van Engen, "should make us aware that Paul is here developing his thought with Hebrew-style pictorial representation or images, rather than with Greek logical propositions." ${ }^{3}$ Van Engen then presents a summary of the different terms used and the frequency with which they are used and finds that at least fifteen different word pictures are used. ${ }^{4}$

The fundamental confessional statements about the church: one, holy and universal, as expressed in the Apostolic confession can be traced back to Paul's treatment on the nature of the church in Ephesians. The following treatment relates Paul's discourse in Ephesians to these statements.

\section{The Oneness of the Body}

The principal image of Paul in Ephesians is that of the unity of the body: The church is one body, there is one Spirit, one hope, one Lord, one faith, one baptism, one God and Father over all, in all and through all (Eph 4:4-6).

${ }^{1}$ Used seventy-three times.

${ }^{2}$ William Barclay, New Testament Words (London: SCM Press, 1964) 70. Barclay points out that the use of the term does not carry with it exclusivity of a few chosen being 'picked out' but rather an inclusiveness of a body of people having been "summoned out' to come and meet with their God."

${ }^{3}$ Ibid.

${ }^{4}$ The most important ones being saints, body, soldier with armor (used 8 times), and wife (used 7 times). Other images further embellish these major conceptions: chosen people of God, and sons and family (used 4 times), workmanship, building, or temple (used 3 times), a song of praise or offering and a new man, or new self (used 2 times). Finally the following are used once: the breadth, length, height and depth of love, imitators of God, kingdom of Christ, children of light, wise men, and ambassadors. Ibid., 48, 49. 
Unity is here conceived of as received as a gift by faith in a broken and divided world. But as the church perceives that oneness it strives to achieve it in the exercise of its individual gifts in service to the world (Eph 4:1-3). But the overriding purpose of the strive toward unity is for the church to grow to be one in "the knowledge of the Son of God," to "grow up into Christ," and to "build itself up in love" (Eph 4:13, 15-16). This growth further issues forth in the incorporation of members (numerical growth), growth through spiritual development (organic and spiritual growth), growth through the increased impact of the body of Christ in the world (growth in diakonia), and growth through greater understanding of the lordship of Christ (theological growth). Thus mission and unity are essential to the purpose of the church in Paul's view.

\section{The Church's Mission in Holiness}

In Ephesians we see the image of the church as a gathering of saints to be a very dominant one (Eph 1:1-14) as Paul calls the church to holy living (5:1-21), to be light in a dark world (5:8-14), and to struggle against evil powers (6:10-18). But also this is an affirmation the church receives by faith and as a gift from God as it painfully senses its evident lack of holiness. But individually and corporately it strives to achieve the holiness which expresses the new self which is formed into the likeness of Christ himself (4:175:14). The purpose of the church is thus to become the children of light (5:8) who illuminate and transform society through transformed lives wherever they are and to do spiritual battle against evil in the world.

True holiness is thus growth in love and the transforming power is the power of the Spirit in the inner person as Christ dwells in the heart through faith and the believer is filled with the fullness of God (3:14-21). 
The Universality of the Mission of the Church

The striking thought in Ephesians is the close affinity presented between Christ and the church, the body. "In the first instarice it is not the community which is called the body, or compared to it, but Christ himself. He is a body. ... It is not that $\sigma \omega \mu \alpha$ is a good image for the community as such, but that Jesus Christ is by nature $\sigma \omega \mu \alpha . \ldots$ The community is not $\sigma \omega \mu \alpha$ because it is a social grouping which as such has something of the nature of organism, which reminds us of an organism.... It is $\sigma \omega \mu \alpha$ because it actually derives from Jesus Christ, because of Him it exists as His body."'

So when Paul presents in Eph 1:15-23 his most exalted representation of Christ (apart from that in Col 1), we must recognize that he also is expressing something about his body, the church. Christ has been raised from the dead; is seated at the right hand of the Father; placed far above all rule and authority; given the rule over every name; all things have been placed in subjection under his feet; he has been given to the church as ruler over all things; he is the head of the body, the church. In him all fullness is manifested. He fills all in all (1:20-24).

Applying this description to the church presents it with a vast universality. This perspective the church accepts in faith as it does not yet see it. But as this vision is confessed in Jesus Christ, the church strives to achieve it in the world (2:1-13). And because the church is for all people, it may never cease to gather everyone to the One who is its head. Thus the church is, in Paul's view, by nature missionary, sent to all people precisely because the head of the Church "fills all in all."

We have here been confronted with Paul's exalted view of the church and his

${ }^{1}$ Karl Barth, Church Dogmatics, vol. 4:2, trans. G. T. Thomson (Edinburgh: T and T Clark, 1958), quoted in ibid., 55. 
powerful vision of its role in mission. It is a vision which emphasizes the centrality and the living reality of the person of Jesus Christ in the life of the church and. This is the church that Christ initiated before his ascension and, empowered by his Spirit, commissioned to accomplish the world-wide reconciliation for which Christ appeared.

Paul was convinced of the urgency of building up of God's kingdom in the world but it was not to be executed by single propagators or by the dissemination of information alone. It was to be carried out existentially by the church, the body of Christ. Here Christ is to be presented as incarnated in human beings through the in-filling of the Spirit, not just through individuals but a community of believers who by faith are united with Christ, live in unity with each other, and work toward uniting the world with him. It is by and from the midst of this spirit empowered, Christ centered church that the final message will be brought to the world as described in Rev 14.

This portrayal of the essential role of the church as community in the accomplishment of mission presents a powerful challenge to the Adventist church which often has relied on single specialists in the carrying out of its mission outreach. The words of Van Engen apply to our situation: “A new missiological paradigm in ecclesiology is needed so that we might see the missionary Church as an "emerging" reality which, as it is built up in the world, becomes in fact what it is in faith. By grasping and internalizing this new paradigm we will find our thinking about the Church and its mission becoming highly contextual, radically transformational, and powerfully hopeful, exercised with eternity in view."'

It is with view to such strengthening of the role and function of the local church as

\footnotetext{
${ }^{1}$ Van Engen, 41.
} 
a powerful witness, a loving environment, and a serving community that this present project is carried out.

\section{Summary}

In this first half of this chapter I have sought to establish a theological foundation for the mission of the Adventist church from a study of the Great Commission in Matthew's Gospel and related texts. I have then compared this text with the message in Rev 14:1-11 which has been recognized by Adventists as the core and quintessence of their mission charge and, finally, surveyed Paul's view on the function of the local church in mission as portrayed in Ephesians.

We noticed that in Matthew's account the method of accomplishing the church's mission is to make disciples of all nations. Its content to be brought to the nations is all that Christ taught, the whole gospel of the kingdom of God as presented in the biblical Gospel accounts, and an invitation to enjoy a personal relationship with the living Lord and be recipients of the power of the gospel as exemplified in the lives of the proclaimers. Christ's followers become motivated to make it their business to do this work when they are filled with Christ's love for humanity and long to enjoy fellowship with Christ. The recipients of this gospel are all the nations, not the least the weak and the needy, and its proclaimers are all those who have received Christ as their Lord and Savior.

Rev 14 presents a scene of intense activity of evangelization of the whole world, but we noticed that no new commission is issued here. Rather, what we are witnessing is an intensification of the gospel proclamation that has been effective since Christ's ascension. It is now called out with a loud voice by a messenger flying in mid-air to every nation on earth in the context of the commencement of the final judgement (i.e., God is 
now active in carrying out the final liberation of his people on earth).

We also noticed in the chapter how the description of the messengers (vss. 1-5) curiously blends in with the description of the content of the message, and the description of this last world-wide effort to accomplish the command of Jesus to evangelize the world coincides with the announcements of the onset of end-time events (thus fulfilling the words of Jesus in Matt 24:14), placing heaven and the final victory in sight.

The announcement of the first angel of judgment, unsettling to some, is joined with a pronouncement of a means ordained by God for protection and close community between himself and his people during the final dark hours of earth's history. It contains the gist of the whole gospel presented in the context of worship as it reminds us of God's covenant faithfulness and gracious care and nearness, but also insists on loyalty towards God's initiative, all enclosed in God's everlasting ordinance, the Sabbath. The second angel further declares that the release of God's children is already evident and under way as the Babylonian power which has relentlessly wrecked havoc on God's ordinances, persecuted God's people, and sought to separate them from their Lord has been rendered powerless. And, finally, the third angel urgently calls all of humanity to make use of God's provisions in the gospel listed above or God cannot do anything further to rescue them.

Adventism, basing its proclamation in the world on the Rev 14 account, must see as the basis for its mission this gospel message and the legacy of the Great Commission which Christ gave his disciples at his ascension. The question may be asked then: If the account in Matthew's Gospel is fully complete and valid as the apostolic gospel commission throughout salvation history in spelling out the content of the Christian mission, why then this emphasis on the Revelation messages? The answer lies in God's 
love, foreknowledge, and care for his people. In the messages of the three angels of Rev 14 the Great Commission is further intensified, strengthened, and made more relevant. These messages must be understood in their context." 'They are a last solemn wake-up call for a dying world to receive of God's gracious provisions before it is too late. But at the same time they are a revelation and a reestablishment, presented in the spirit of intimacy and concern which characterize the whole book of Revelation, of the eternal and absolutely necessary provisions for the security of God's people in the end as they face terrible persecution and attacks by the arch enemy during the final scenes of earth's history.

Finally, we recognized the missionary nature of the church through the images presented by Paul in Ephesians were confronted with his powerful vision of the mission mandate to be carried out by and through the church. It is a community which receives holiness as a gift by faith, strives for individual and corporate holiness and the transformation of culture. And it is a community which confesses its universal obligation to all men in Jesus Christ and strives to accomplish it in the world until "Christ is all in all."

We will now turn our attention to Ellen G. White's portrayal of the nature and the role of the church and her rich practical counsel as to the operation of the church at the close of earth's history.

\section{Mission and Ministry of the Church in the Writings of Ellen G. White}

Introduction

In the latter part of this chapter I will seek to examine a representative selection of 
the practical counsel and admonitions of Ellen G. White to the chief factors in the carrying out of the mission of the Adventist Church. I will seek to gain an understanding of her view on the main priorities the church must have as a practical consequence of the theological understanding of the mission of the church. In this context I will inquire into her view of the nature and the authority of the Church, the nature of the commissioning of its pastors and their relationship to the laity, and the role of the laity in church operations.

The method used here to communicate a conception of the view of Mrs. White on these issues is to present a carefully selected collection of rather short quotations from her writings with comments that aim at crystalizing the central thought in her counsel. In spite of the limited scope of this paper I have sought to convey a fair perception of the intended meaning of Mrs. White's statements. This has in some instances required some quite lengthy quotes in order to convey the full impact.

\section{Contextual Factors Relating to the Counsel of Ellen G. White}

It is with the understanding that the counsel of Ellen G. White is God's special message to an emerging Adventist Church and his intervention in the setting of its course that we approach her writings in this chapter. But in order to gain a better appreciation of her treatment of the issues to be dealt with here, it is significant to be aware of the context in which these concepts were presented and in what environment this new denomination was being formed. The tradition of the churches out of which the Adventists had come-their strong mission emphasis, characteristic role of the clergy and especially the active involvement of lay people in the operation of the churches-would strongly affect their understanding of how churches were operated. Pastors in the Methodist and Baptist (and 
other) churches were, in the beginning of the nineteenth century, mostly itinerant preachers strongly involved in evangelism and the raising up of new churches, and each was in charge of many congregations which he visited from time to time. Much of the operation of the congregations was then in the hands of lay people. In this context the role of the well-known class meetings in Methodism, especially during the formative years of that church, was significant. ${ }^{1}$ Here the leaders were always lay people, more often women than men. The importance of this institution in the doctrinal instruction, nurture and counseling of the members in the growing phase of the Methodist movement in England and America was inestimable as it emphasized personal sanctification and accountability in the Christian life. The role of the pastor then was that of an overseer and an authority figure in the churches but first and foremost as a pioneer in pushing forward into new territory by raising up and fostering new groups and societies. From the beginning the Methodist church was very much a missionary movement in America like its pioneers in England had also been. The idea was strong to push west and conquer new territory for the gospel.

On the other hand it must also be remembered that by the mid- nineteenth century these churches were rapidly becoming highly centralized, and that the Adventists had systematically, both laymen and ministers, been expelled from the established churches following the Second Advent Awakening. ${ }^{2}$ This caused them, in Adventist terminology, to fill the category of spiritual Babylon. This was instrumental in making Adventists shun any form of organization to begin with as they equated firmly organized church structure

\footnotetext{
${ }^{1}$ Ellen White and her family who were devout Methodists were all members of classes held in private homes. See Ellen G. White, Life Sketches (Mountain View: Pacific Press, 1943), 165.

${ }^{2}$ Ellen Harmon and her family were disfellowshipped from the Methodist Episcopal Church in Portland, Main, in September 1843 after a formal church trial. Ibid., 43-53.
} 
with rigidity, unresponsiveness to the voice of God, and apostasy from true religion.

Against this background it is interesting to see how Ellen G. White sought to influence the formation and development of the workforce of the new church and the engagement of the laity in order that it be effective in accomplishing its mission.

\section{The Nature and the Role of the Church}

Ellen White's view of the nature and the role of the church in God's plan for humankind is a very high one. The church, "enfeebled and defective as it may be," is God's property on earth, "the only object on earth on which He bestows His supreme regard," and through it he intends to herald and demonstrate eternal salvation by grace to the world and even the whole universe through worship, proclamation, and transformation of human lives: "The Son of God identified Himself with the office and authority of His organized church. His blessings were to come through the agencies that He has ordained, thus connecting man with the channel through which His blessings come." ${ }^{2}$ The success of the church is crucial in God's plan and its failure would frustrate his purpose in the world: "His [God's] authority should be kept distinct and plain before the world, and no laws are to be acknowledged that come in collision with the laws of Jehovah. If in defiance of God's arrangements the world be allowed to influence our decisions or our actions, the purpose of God is defeated." ${ }^{3}$

But God's wonderful project with human beings through the church, empowered

IEllen G. White, Testimonies to Ministers (Mountain View, CA: Pacific Press, 1962), 15, 17.

${ }^{2}$ White, Testimonies for the Church, 3:432.

${ }^{3}$ Ellen G. White, Christian Experience and Teachings of Ellen G. White (Mountain View: Pacific Press, 1940), 207. 
the Holy Spirit, cannot be overthrown by outside forces: "The Lord Jesus is making experiments on human hearts through the exhibition of His mercy and abundant grace. He is effecting transformation so amazing that Satan, with all his triumpinant boasting, with all his confederacy of evil united against God and the laws of His government, stands viewing them as a fortress impregnable to his sophistries and delusions. They are to him an incomprehensible mystery."'

At his ascension Christ entrusted men with this treasure, to be "representatives of Christ, as Christ was a representative of the Father." It is not the duty of the clergy alone to shoulder this responsibility but all of Christ's followers on earth: “This work cannot be left to the ministers alone, or to a few leading men. Every member should feel that he has entered into a solemn covenant with the Lord to work for the best interests of his cause at all times and under all circumstances. Each should have some part to act, some burden to bear." "God's Spirit convicts sinners of the truth, and He places them in the arms of the church. The ministers may do their part, but they can never perform the work that the church should do. ${ }^{4}$

\section{The Authority of the Church}

If the church as Christ's possession has as its primary duty to represent him on earth then God has, according to Mrs. White, invested authority in the church that must not be disregarded: "Many have the idea that they are responsible to Christ alone for their

\footnotetext{
'Ibid., 209, 210.

${ }^{2}$ Ellen G. White, Reflecting Christ (Hagerstown, MD: Review and Herald, 1985), 213.

${ }^{3}$ Ellen G. White, Gospel Workers (Washington, DC: Review and Herald, 1948), 200.

${ }^{4}$ Ibid., 352.
} 
light and experience, independent of His acknowledged followers in the world. But this is condemned by Jesus in His teachings and in the examples, the facts, which He has given for our instruction.... It [the church] is Christ's organized body upon the earth, and respect is required to be paid to His ordinances." "The Redeemer of the world does not sanction experience and exercise in religious matters independent of His organized and acknowledged church, where He has a church."2

But this authority is not censorship by the ordained ministry over the church but means to secure unity in experience and purpose in the church. ${ }^{3}$ If the role of authority within the church rests particularly with the ministry, this is solely due to their election to a position of leadership and added responsibility within the church. But their authority can only ultimately be derived from their shared membership in the body of Christ with all those who believe in Christ.

\section{The Ordination of Ministers, the Gifts of the Spirit, and a Call for Church Unity}

In the context of the above-mentioned, it is enlightening to inquire into the nature of the selection of individuals for ministerial work and the ordination for ministry. But this must be observed in Mrs. White in the wider context of the varied gifts of the Spirit in the church and unity of the Spirit.

\section{Ordination of Ministers}

Ordination, the selection of individuals for a very significant position and sacred

${ }^{1}$ White, Testimony for the Church, 3:433.

${ }^{2}$ Ibid., 3:432.

${ }^{3}$ See White, Gospel Workers, 484, third paragraph. 
duty in the church, lies not with man but with God. The laying on of hands by the church on pastors, and on local church officers for that matter, is done as a public recognition of a selection which the Holy Spirit has already made: "Paul did not depend upori man for his ordination. He had received from the Lord his commission and ordination."

Mrs. White further points out that this "setting apart" is an appointment of individuals for a certain role of leadership and responsibility in the mission of the church and a stamp of authorization by the church to make its mission legitimate and more effective. ${ }^{2}$ Certainly the act does not confer on the individual any added or special ability as is the understanding in some churches. ${ }^{3}$

But to neglect to recognize the thus appointed leadership of the church is to reject a divine ordinance: "To neglect or despise those whom God has appointed to lead out and to bear the responsibilities connected with His work and with the advancement and spread of the truth is to reject the means which God has ordained for the help, encouragement, and strength of His people."

l"Ellen G. White Comments-1 Corinthians," SDA Bible Commentary, 6:1088. In another place White states: "Both Paul and Barnabas had already received their commission from God himself; and the ceremony or the laying on of hands added no new grace or virtual qualification. It was merely setting the seal of the church upon the work of God - an acknowledged form of designation to an appointed office." Idem, Sketches from the Life of Paul (Washington, DC: Review and Herald, 1974), 43, 44.

${ }^{2}$ "The Christian church was at this time entering upon an important era. The work of proclaiming the gospel message among the Gentiles was now to be prosecuted with vigor; and as a result the church was to be strengthened by a great ingathering of souls. . . God foresaw the difficulties that His servants would be called to meet, and, in order that their work should be above challenge, He insiructed the church by revelation to set them apart publicly to the work of the ministry. Their ordination was a public recognition of their divine appointment to bear to the Gentiles the glad tidings of the gospel." White, Acts of the Apostles (Mountain View: Pacific Press, 1911), 161.

${ }^{36}$ The ordination by the laying on of hands, was, at a later date, greatly abused; unwarrantable importance was attached to the act as though a power came at once upon those who received such ordination, which immediately qualified them for any and all ministerial work, as though virtue lay in the act of laying on of hands." White, Sketches from the Life of Paul, 43, 44.

${ }^{4}$ White, Testimonies for the Church, 3:418. 
Varied Gifts of the Spirit in the Church

The ordained ministers are then a divinely appointed leadership for the church, effected through the cail of the Holy Spirit and recognized by the church body. But the leaders of the church are not to rule with a heavy hand or in a dictatorial way but must recognize that the real owner of the church is Jesus Christ and that "God has placed in the church, as His appointed helpers, men of varied talents, that through the combined wisdom of many the mind of the Spirit may be met,"1 and without which the church would not function effectively. The individuality of the gift of each of God's servants adds to the richness and the versatility of the ministry of the church.

Every church needs all its gifted members to accomplish its mission while no one person possesses all the gifts. ${ }^{2}$ Thus the strength of the church lies in the discovery and the harmonious cooperation of this multiplicity of diverse gifts and abilities in the church. Even among the ministerial workers there are different abilities that must be recognized: "Men have varied gifts, and some are better adapted to one branch of the work than another. What one man would fail to do, his brother minister may be strong to accomplish. The work of each in his position is important. One man's mind is not to control that of another. If one man stands up, feeling that no one shall influence him, that he has judgment and ability to comprehend every branch of the work, that man will fail of the grace of God." ${ }^{33}$

But again White points out the importance of the role of the Spirit-filled and Spirit-

\footnotetext{
${ }^{1}$ See White, Acts of the Apostles, 279.

${ }^{2}$ See ibid., 274, 275; idem, Gospel Workers, 481, 483.

${ }^{3}$ White, Testimonies for the Church, 4:608, 609.
} 
led lay people who are, although outside the ranks of the ordained ministry, of critical importance to the successful accomplishment of the mission of the church of Christ:

While some with special talents are chosen to devote all their energies to the work of teaching and preaching the gospel, many others, upon whom human hands have never been laid in ordination, are called to act an important part in soulsaving. ... The self-sacrificing servant of God who labors untiringly in word and doctrine, carries on his heart a heavy burden. ... His wages do not influence him in his labor. ... From heaven he received his commission, and to heaven he looks for his recompense when the work entrusted to him is done.

In fact, there is no one in the church whom God has not endowed with some gift or ability which can be cultivated and used to his glory in the work and the advancement of the kingdom and all must feel they have an essential part to play: "To every person is committed some peculiar gift or talent which is to be used to advance the Redeemer's kingdom. All God's responsible agents, from the lowliest and most obscure to those in high positions in the church, are entrusted with the Lord's goods. It is not the minister alone who can work for the salvation of souls."

\section{The Call for Church Unity}

Mrs White sees unity as a requirement for the working of the Holy Spirit within the church, so diverse in spiritual gifts and abilities. This is an essential condition for it to accomplish its divinely appointed task. Only if there be true humility and divinely inspired love exhibited in the character of church leadership and permeating the church as a whole can there be a co-operation of the human with the divine. But then, difference of opinion does not have to lead to disunity:

"The Lord desires His chosen servants to learn how to unite in harmonious effort.

\footnotetext{
${ }^{1}$ Ellen G. White, Conflict and Courage (Washington, DC: Review and Herald, 1970), 342.

${ }^{2}$ White, Testimonies for the Church, 4:618.
} 
Their talents, however diverse, may all be under the control of the same Spirit. In every word and act, kindness and love will be revealed; and as each worker fills his appointed place faithfully, the prayer of Christ for the unity of His followers will be answered, and the world will know that these are His disciples." "Those who do labor together should seek to be in perfect harmony... . God has set in the church different gifts. These are precious in their proper places, and all may act a part in the work of preparing a people for Christ's soon coming."2

God has purposely chosen to work through a multiplicity of gifts and abilities but God's purpose will not succeed without cooperation and unity. "Let not one man feel that his gift alone is sufficient for the work of God; that he alone can carry through a series of meetings, and give perfection to the work. His methods may be good, and yet varied gifts are essential. ... Cooperation and unity are essential to a harmonious whole, each laborer doing his God-given work, filling his appropriate position, and supplying the deficiency of another. One worker left to labor alone is in danger of thinking that his talent is sufficient to make a complete whole."

The striving for unity is in fact the sign of true conversion and the presence of the Spirit of Jesus: "Those who are truly converted will press together in Christian unity. Let there be no division in the church of God, no unwise authority exercised over those who accept the truth. The meekness of Christ is to appear in all that is said and done... Let

\footnotetext{
'White, Gospel Workers, 483.

${ }^{2}$ Ibid., 481.

${ }^{3}$ Ellen G. White, Evangelism (Washington, DC: Review and Herald, 1946), 104.
} 
Christ appear; let self be hidden behind Him. This is self-sacrifice that is of worth."

Only by these means will true religion be exhibited as God unites with his people and they seek unity among themselves: "In loving sympathy and confidence God's workers are to unite with one another. He who says or does anything that tends to separate the members of Christ's church, is counterworking the Lord's purpose.... True religion unites hearts, not only with Christ, but with one another, in a most tender union. When we know what it means to be thus united with Christ, and with our brethren, a fragrant influence will attend our work wherever we go."

To accomplish this a decided effort must be made, a readiness developed to seek to understand the viewpoint of others and to yield personal opinions when needed and a readiness shown to be educated by God himself: "Not one moment of our precious time should be devoted to bringing others to conform to our personal ideas and opinions. God would educate men engaged as co-laborers in this great work, to the highest exercise of faith, and the development of a harmonious character."

This spirit of teachability, humility and the need for the wisdom of others is the condition for success in God's work, and as we unite in desire and purpose for growth in the work and in prayer to God he will answer and bestow his blessing on the work: "Our Saviour follows His lessons of instruction with a promise that if two or three should be united in asking anything of God it should be given them. Christ here shows that there must be union with others, even in our desires for a given object. Great importance is

\footnotetext{
${ }^{1}$ White, Testimonies for the Church, 9:147.

${ }^{2}$ White, Gospel Workers, 484.

${ }^{3}$ White, Testimonies for the Church, 4:608.
} 
attached to the united prayer, the union of purpose... There must be an agreement in the things which they desire and for which they pray ... earnest desire of several minds centered on the same point."

This is the outworking on earth of the divine unity in heaven which allows for the cooperation with the divine: "The Lord in His wisdom has arranged that by means of the close relationship that should be maintained by all believers, Christian shall be united to Christian, and church to church. Thus the human instrumentality will be enabled to cooperate with the divine."

Mrs. White often spoke against the independent or controlling spirit among ministers and administrators of the church, employing terms like "individual independence" ${ }^{3}$ or "kingly power"4 which she saw as being of the enemy and of great detriment to the church.

Thus in White's above exposition of church governance, based on the way Christ governs his church, a qualitative separation between "clergy" and "laity" in the church is absent as it becomes clear that it is only as "laity," as the people of God, that we have a mandate to act on God's behalf in this world. It becomes clear that all of God's people are in fact called and equipped to represent Christ in the world. The difference between the ministers of the church and its membership lies in their duty to represent Christ to the church itself and the added responsibility on their shoulders. To Ellen White's description

\footnotetext{
IIbid., 3:429.

${ }^{2}$ White, Gospel Workers, 444.

${ }^{3}$ Ibid., 443, 444.

${ }^{4}$ Ellen G. White, Spalding and Magan's Unpublished Manuscript Testimonies of Ellen G. White
} (Payson, AZ: Leaves-of-Autumn, 1980), 368. 
of this solemn task and daunting responsibility of the gospel minister we now turn.

\section{Descriptions of the Role of the Ministry}

\section{A Watchman}

According to Ellen White the minister is a representative of Christ in the church as the church is in the world and he must recognize his awesome responsibility of being a watchman and spiritual guardian, a steward, and a faithful shepherd of the church of Christ entrusted to his care in the world. His is thus the prophetic as well as the didactic role in the community. Mrs. White uses the description of Ezekiel the prophet of the watchman:

"Christ's ministers are the spiritual guardians of the people entrusted to their care. Their work has been likened to that of watchmen. . . Upon their faithfulness depended the safety of all within." With this guardianship goes the role of "administering the mysteries of God" and the vital duty to stay in an intimate relationship with God so as to be able to discern danger and to warn against temptation or else to assume the responsibility for the consequences, the straying away by some to their eternal loss:

To every minister the Lord declares: "O son of man, I have set thee a watchman unto the house of Israel." Ezekiel 33:7-9. . . . The words of the prophet declare the solemn responsibility of those who are appointed as guardians of the church of God, stewards of the mysteries of God. . . These watchmen represent the ministry, upon whose fidelity depends the salvation of souls. The stewards of the mysteries of God should stand as watchmen upon the walls of Zion; and if they see the sword coming, they should sound the note of warning. If they are sleepy sentinels, if their spiritual senses are so benumbed that they see and realize no danger, and the people perish, God will require their blood at the watchmen's hands. ${ }^{2}$

\footnotetext{
${ }^{1}$ White, Acts of the Apostles, 360, 361.

${ }^{2}$ Ibid., 361 .
} 


\section{Representatives of Christ}

The ministers of the gospel are called to represent Christ in the Church and, as leaders of it, to represent the church in the world. This Mrs. White signifies by her reference to the seven stars of Revelation 1 which Christ holds in his hand. Here the focus is on the servant-leadership role of the pastor as acting in Christ's stead. And yet also the interchangeability between the pastor and the church are emphasized as through his work in the church the pastor strives towards strengthening the church in its own representative role of Christ in the world as it brings light of true doctrine to the world, calls men and women to receive God's grace and new life and presents to the world the sweet Spirit of Christ's love: "When, in the midst of his blind error and prejudice, Saul was given a revelation of the Christ whom he was persecuting, he was placed in direct communication with the church, which is the light of the world. In this case Ananias represents Christ, and also represents Christ's ministers upon the earth, who are appointed to act in His stead."1 "The position of those who have been called of God to labor in word and doctrine for the upbuilding of His church, is one of grave responsibility. In Christ's stead they are to beseech men and women to be reconciled to God, and they can fulfill their mission only as they receive wisdom and power from above." "God's ministers are symbolized by the seven stars, which He who is the first and the last has under His special care and protection. The sweet influences that are to be abundant in the church are bound up with these ministers of God, who are to represent the love of Christ."

\footnotetext{
${ }^{1}$ Ibid., 122.

${ }^{2}$ Ibid., 360.

${ }^{3}$ Ibid., 13.
} 
Faithful Shepherds of the Flock

The method of pastoral labor in the churches advocated by Mrs. White is that of earnest personal engagement rather than sermonizing, and training and disciplining with unselfish love rather than intimidating dominance:

Those who occupy the position of undershepherds are to exercise a watchful diligence over the Lord's flock. This is not to be a dictatorial vigilance, but one that tends to encourage and strengthen and uplift. Ministry means more than sermonizing; it means earnest, personal labor. . . Pastors are needed-faithful shepherds-who will not flatter God's people, nor treat them harshly, but who will feed them with the bread of life - men who in their lives feel daily the converting power of the Holy Spirit and who cherish a strong, unselfish love toward those for whom they labor.'

\section{Charged to Tell of the Binding Claims of God's Law}

Finally, the ministers of the church must understand the unparalleled, solemn importance of their duty and prepare to face a final scrutiny of their work as to whether they have clearly presented the "binding claims of God's law" and rightfully displayed the attractiveness of the salvation in Jesus Christ to be found in God's word. But while the responsibility lies squarely on the shoulders of the pastors to maintain the standard of truth and practice in the church this does not excuse each church member who finally is personally accountable:

Upon the ministers of God rests a solemn, serious charge. They will be called to a strict account for the manner in which they have discharged their responsibility. If they do not tell the people of the binding claims of God's law, if they do not preach the Word with clearness, but confuse the minds of the people by their own interpretations, they are shepherds who feed themselves, but neglect to feed the flock. ... The blood of these souls will be upon their heads. God will call them to account for their unfaithfulness. ${ }^{2}$

\footnotetext{
'Ibid., 526.

${ }^{2}$ Ellen G. White, "Ellen G. White Comments-Ezekiel," SDA Bible Commentary, 4:1164.
} 


\section{The Priority of Evangelism}

\section{Ministers Called to Raise Up New Churches}

In Ellen White's mind the main purpose of the church on earth is evangelism, the spreading of the light of salvation to the whole world. Only through the efficient discharge of this task can it legitimize its existence. And to her the most efficient way to accomplish this is to raise up churches as lighthouses on as many hills of the world as possible as loving evangelistic communities exhibiting the character of Christ. The right division of labor to her is to free the pastors as much as possible for the work of the raising up of new companies while the existing churches look after the maintenance of the established church: "Instead of laboring among the churches, God designs that our ministers should spread abroad, and our missionary labor be extended over as much ground as we can possibly occupy to advantage, going in every direction to raise up new companies." "Our ministers are not to spend their time laboring for those who have already accepted the truth. With Christ's love burning in their hearts, they are to go forth to win sinners to the Saviour. Beside all waters they are to sow the seeds of truth. Place after place is to be visited; church after church is to be raised up. Those who take their stand for the truth are to be organized into churches, and then the minister is to pass on to other equally important fields."

\section{Ministers Not to Spend Too Much Time with the Converted}

This being the ideal Ellen White was perturbed by the tendency seen in many

${ }^{1}$ White, Testimonies for the Church, 3:210.

${ }^{2}$ Ibid., 7:19. 
churches grounded in the "truth" for settled pastors, a tendency which to her indicated a loss of evangelistic fervor: "Our people have received great light, yet much of the ministerial force has been spent on the churches, teaching those who should be teachers; enlightening those who should be "the light of the world;" watering those from whom should flow rivers of living water; enriching those who might be mines of precious truth."

In her mind the incessant call for greater care and service by settled pastors would lead to inactivity by the members themselves which in turn produced weakness on their part and a great setback for the church as a whole: "There should not be a call to have settled pastors over our churches, but let the life-giving power of the truth impress the individual members to act, leading them to labor interestedly to carry on efficient missionary work in each locality." "The Lord's great vineyard demands from men that which it has not yet received - earnest, persevering labor for souls. The ministry is becoming weak and feeble, and under their tame service the churches also are becoming weak.... Why are the ministers who should be laboring in special service earnestly to open new fields and raise up new churches, hovering over the churches which have already received great light and many advantages which they do not appreciate?"3

Ellen G. White was quite outspoken against this tendency within the church to absorb its ministerial staff more and more in pastoral duties of "setting the church right," serving those who had received the light and should in fact be light bearers to others. This she sees as a wrong development-professional, paid staff being taken from their most

\footnotetext{
${ }^{1}$ Ibid., 24.

${ }^{2}$ Ellen G. White, "The Work in Greater New York," Atlantic Union Gleaner, January 8, 1902, 9.

${ }^{3}$ Ellen G. White, Manuscript Releases (Silver Spring, MD: Ellen G. White Estate, 1993), 13:208,
} 209. 
pressing duties of evangelism. Still this should not be understood as if Ellen White did not see any need for spiritual nurture for members of the church. She most certainly did, as we will see later in this chapter. She only wanted to underline strongly the pre-eminent missionary calling of the church which should not be hampered by internal needs of the missionary community:

God has not given His ministers the work of setting the churches right. No sooner is this work done, apparently, than it has to be done over again. Church members that are thus looked after and labored for become religious weaklings. If nine tenths of the effort that has been put forth for those who know the truth had been put forth for those who have never heard the truth, how much greater would have been the advancement made! God has withheld His blessings because His people have not worked in harmony with His directions. ${ }^{1}$

The time you devote to imparting constantly to those who understand the message of warning will not give one tithe of the strength which they would receive in taking hold of the work to communicate life to save perishing souls. Angels are waiting to bless the consecrated workers. The parable of the lost sheep should be a lesson to every soul who has been rescued from the snare of Satan. We are not to hover over the ninety and nine, but to go forth to save the lost, hunting them up in the wilderness of the large cities and towns. ${ }^{2}$

The messages here follow a clear formula: The Church is about mission and the worship services of the church are for the preparation for mission. White even goes so far as to say that there is little point for members in coming for the service week after week if they never employ their time during the week to utilize the instruction given. But if members would in fact involve themselves in evangelism, their experience shared on Sabbath morning with others would be a tremendous blessing for all:

It weakens those who know the truth for our ministers to expend on them the time and talent that should be given to the unconverted. In many of our churches in the cities the minister preaches Sabbath after Sabbath, and Sabbath after Sabbath the church members come to the house of God with no words to tell of blessings received because

'Ibid.

${ }^{2}$ White, Testimonies to Ministers, 232. 
of blessings imparted. They have not worked during the week to carry out the instruction given them on the Sabbath. So long as church members make no effort to give to others the help given them, great spiritual feebleness must result. ${ }^{1}$

\section{Pastoral Work in the Churches}

Sharing the Burden

If in fact, as labored here above, the paid ministerial staff is not to devote its time taking care of the spiritual nurture of the members of established churches how should then that important work be cared for? Members from the church itself should take part in this work, and in fact God will "impress the individual member" to act and to do valuable work. But these people must then in turn be "educated and trained' by the church leadership for their work. People thus acquired for service will prove more effective for certain tasks than the ordained pastor: "As the hand of God, the church is to be educated and trained to do effective service. Its members are to be the Lord's devoted Christian workers. The church of today is too one-sided." "It is not the Lord's purpose that ministers should be left to do the greatest part of the work of sowing the seeds of truth. Men who are not called to the ministry are to be encouraged to labor for the Master according to their several ability. Hundreds of men and women now idle could do acceptable service."

\section{Preaching}

\section{Feeding the Flock}

Ellen White's counsel on the importance of pastoral duties for the church

I'Ibid.

${ }^{2}$ White, "The Work in Greater New York," 9.

${ }^{3}$ White, Testimonies for the Church, 7:21. 
members, covered in this chapter under the headings "Preaching" and "The Importance of Personal Work," should not be seen as contradictory to what we have been studying so far where the priority of evangelism has been stressed. The spreading of the gospel and the growth of the church must take place first, as conversion growth is the lifeline of the church, but the preaching of the word in the church and the nurture of its membership is also of critical importance but comes in second place as it derives its validity from its ability to maintain the evangelistic drive in the church.

In her counsel to the preachers of the church Ellen White urges them, first, to see themselves as the successors of Peter called to "feed the sheep" of Christ. Second, they are in their preaching "called to give to every man his portion of meat in due season," involving intimate knowledge of the congregation, and, third, they are called to turn the eyes of the congregation to behold Jesus: "The charge given to Peter should come home to nearly every minister. Again and again the voice of Christ is heard repeating the charge to His undershepherds, "Feed My lambs," "Feed My sheep.". . In the words addressed to Peter the responsibilities of the gospel minister who has charge of the flock of God are laid before him." "When men and women accept the truth, we are not to go away and leave them and have no further burden for them. They are to be looked after.... Then as you speak to the people, give to every man his portion of meat in due season, but you want to be in that position where you can give this food.". "My brethren in the gospel ministry, let us feed the flock of God. Let us bring encouragement and cheerfulness to every heart. Let us turn the eyes of our brethren and sisters away from the unlovely traits of character

\footnotetext{
${ }^{1}$ Ibid., 345, 346.

${ }^{2}$ White, Evangelism, 345.
} 
possessed by nearly everyone, and teach them to behold Christ, the One altogether lovely, the Chiefest among ten thousand."'

\section{Short Sermons}

In White's mind the sermon plays an important role in the church service but still its essentiality to the life of the church has been greatly overestimated. Especially when sermons become too long and they are presented at the expense of other often more effective pastoral work they are a liability in the work of the church. Thus she suggests the shortening of sermons by half and the doubling of individual work with the membership. This would enhance the effectiveness of the work of the minister. Also she points out that members need not expect a sermon every Sabbath: "There are times when it is fitting for our ministers to give on the Sabbath, in our churches, short discourses, full of the life and love of Christ. But the church members are not to expect a sermon every Sabbath."2

A minister is one who ministers. If you confine your work to sermonizing, the flock of God will suffer; for they need personal effort. Let your discourses be short. Long sermons wear out both you and the people. If ministers would make their sermons only half as long, they would do more good and would have strength left for personal work. Visit families, pray with them, converse with them, search the Scriptures with them, and you will do them good. Give them evidence that you seek their prosperity, and want them to be healthy Christians. ${ }^{3}$

"That which is spoken in the first hour is of far more value if the sermon closes then than the words that are spoken in an added half hour. There is a burying up of the matter that has been presented." "If one half of the sermonizing were done, and double the amount of

\footnotetext{
'Ibid.

${ }^{2}$ White, Testimonies for the Church, 7:19.

${ }^{3}$ White, Evangelism, 348.

${ }^{4}$ White, Testimonies to Ministers, 256.
} 
personal labor given to souls in their homes and in the congregations, a result would be seen that would be surprising."

\section{Not a Sermon Every Sabbath}

White suggests that a Bible Class is often appropriate instead of a sermon on Sabbath thus making a point in favor of personal involvement and profitability for every member:

It has often been presented to me that there should be less sermonizing by ministers acting merely as local pastors of churches, and that greater personal efforts should be put forth. Our people should not be made to think that they need to listen to a sermon every Sabbath. Many who listen frequently to sermons, even though the truth be presented in clear lines, learn but little. Often it would be more profitable if the Sabbath meetings were of the nature of a Bible class study. Bible truth should be presented in such a simple, interesting manner that all can easily understand and grasp the principles of salvation. ${ }^{2}$

\section{The Social Meeting}

Favoring personal involvement and practicality of religion Mrs. White frequently endorsed a lively, intelligent and meaningful worship service where a short sermon was followed by what was called a social meeting, an event where everyone was encouraged to testify about his or her experience with Jesus as a personal savior and even to make a public confession: "The preaching service should generally be short, so that an opportunity may be given to those who love God to express their gratitude and adoration. Prayer and praise offered to God by His believing children honors and glorifies His name."3

"Everyone has a part to act and something to do in the cause of God. None of you should

\footnotetext{
${ }^{1}$ White, Evangelism, 430.

${ }^{2}$ Ibid., 348.

${ }^{3}$ White, Manuscript Releases, 32a:2.
} 
keep silent in your meetings. Surely everyone who has tasted of the powers of the world to come can say something in honor of the lovely Jesus." "A few pointed words in relation to your progress in the divine life, spoken in a clear, audible voice, in an earnest manner, without any effort of speech, would be edifying to others and a blessing to your own soul."

The Importance of Personal Work

\section{Personal Work and Visitation}

This section discusses what White calls personal work, which she stresses very much in her counsel to ministers. This part of the work includes visitation and personal talks with members and attendees but covers more than that. What she opposes in these statements is the tendency by some ministers to concentrate their effort on preaching in their churches, often without much effect, while maintaining a distance between themselves and their listeners as to avoid personal involvement with them. Such work is inadequate and exhibits an attitude not in harmony with that of Christ: "Visiting from house to house forms an important part of the minister's labors. He should aim to converse with all the members of the family, whether they profess the truth or not. It is his duty to ascertain the spiritual condition of all." "Come close to the people; get into the families when you can; do not wait for the people to hunt up the shepherd. Bear with you the confidence and assurance of faith which evidences that you are not trusting in idle tales

\footnotetext{
${ }^{1}$ White, Manuscript Releases, Letter 30, 1850, p. 2.

${ }^{2}$ White, Testimonies to the Church, 4:123.

${ }^{3}$ Ibid., 2:338.
} 
but in a plain "Thus saith the Lord."' "This house-to-house labor, searching for souls, hunting for the lost sheep, is the most essential work that can be done." "The pastor should visit from house to house among his flock, teaching, conversing, and praying with each family, and looking out for the welfare of their souls. Those who have manifested a desire to become acquainted with the principles of our faith should not be neglected, but thoroughly instructed in the truth." "When the discourses are given in the desk, the work is just entered upon. Then the minister should, by personal effort if possible, become acquainted with every one of his hearers."

In a letter which Ellen White wrote in Australia in March 1892 she deals with these same issues in a remarkable way. Here she says in effect that the work done in preaching becomes of little or no avail to the listeners if not followed up by personal work and visitation by the pastor, and through his visitation he gains the knowledge he needs to be able to serve the people effectively in the pulpit and elsewhere. She sees this work in fact as "the most important of the shepherd's duty" and goes so far as to says that "if a man fails to do this part of the work, he can not be a minister after God's order" and is not fit for the job: "Better have one thorough shepherd who will care for the flock as a faithful shepherd should, than to have twenty sermonizers who will excuse themselves, saying, "It is not in my line to visit; I cannot visit the church in their families." Then let there not be a moment's hesitation in telling them, "We do not propose to accept you and give you

\footnotetext{
'Ibid., 158.

${ }^{2}$ Ibid.

${ }^{3}$ White, Testimonies for the Church, 4:266.

${ }^{4}$ White, Evangelism, 157.
} 
credentials. You cannot labor. But educate yourself to do a shepherd's work, to care for the sheep and lambs."

\section{The Importance of Getting Close to People}

I include here a few statements by White in order to discover a little further why she stresses so much this aspect of the pastoral work. By getting close to people the minister is given a golden opportunity to enter, not only the homes of his members, but also their lives and to get into touch with their feelings, to "come close to their hearts." Here, much more than in "sermonizing," he has the opportunity to "reveal the love of Christ in personal ministry" and enter into "real heart-to-heart work" as White expresses it. What could be more important than this and how could ministry be effectively carried out without including this dimension?: "Come close to your brethren; seek for them, help them; come close to their hearts as one touched with the feelings of their infirmities. Thus we may achieve victories that our small faith has not grasped." "In the work of many ministers there is too much sermonizing and too little real heart-to-heart work. There is need of more personal labor for souls. In Christlike sympathy the minister should come close to men individually, and seek to awaken their interest in the great things of eternal life. ${ }^{3}$

\section{The Importance of Understanding and} Adapting to People's Needs

Finally, on the issue of coming close to people in an evangelistic outreach of the

\footnotetext{
${ }^{1}$ lbid., 17, 18.

${ }^{2}$ White, Evangelism, 347.

${ }^{3}$ White, Gospel Workers, 185.
} 
church White advocated the adoption of the method of Christ where genuine love and a pure interest in the well-being of humanity was the driving force behind his service for the people: "Christ's method alone will give true success in reaching the people. The Saviour mingled with men as one who desired their good. He showed His sympathy for them, ministered to their needs, and won their confidence. Then He bade them, 'Follow me."' "There is need of coming close to the people by personal effort. If less time were given to sermonizing, and more time were spent in personal ministry, greater results would be seen. The poor are to be relieved, the sick cared for, the sorrowing and the bereaved comforted, the ignorant instructed, the inexperienced counseled, We are to weep with those that weep, and rejoice with those that rejoice. Accompanied by the power of persuasion, the power of prayer, the power of the love of God, this work will not, cannot, be without fruit." By keeping the interest of others in mind, effort will be made to understand those that the church seeks to work for, and narrow and time-honored plans and methods will be laid aside in favor of approaches that are adapted to every condition: "We are living in the midst of a crooked and perverse generation, and our nice and exact plans cannot always be carried out to the advantage of all. If we stand back upon our dignity we shall fail to help those who need help the most. The servants of Christ should accommodate themselves to the varied conditions of the people. They cannot carry out exact rules if they meet the cases of all. Labor will have to be varied to meet the people where they are."

\footnotetext{
${ }^{1}$ Ellen G. White, Ministry of Healing (Mountain View, CA: Pacific Press, 1937), 143.

${ }^{2}$ Ibid.

${ }^{3}$ White, Testimonies for the Church, 2:672.
} 


\section{The Role of the Laity in the Church}

The Necessity of Involving Lay People in Active Service

We have earlier noticed the importance Ellen White places on the division of labor to be maintained in the church, that the working of new fields and the raising up of new churches should be in the hands of the ministers, while the operation of the established church should be in the hands of the church members themselves, often relying on the sharing of their own spiritual experience during Sabbath gatherings (further developed in her promotion of the "social meeting" concept). In spite of statements underlining the critical importance of personal work for the real and lasting effect of the message preached which we have just been considering, this division of labor is still to be the general rule to be followed. This harmonizes with the arrangement in other successful denominations by whom Adventists were influenced as mentioned in the introduction to this section of the present chapter; there member-care was also in the hands of lay members and often the venue for their spiritual control and nurture was the small group. This was very much how the Adventist church was operated in America from 1870 to 1900 , a time of phenomenal growth in the church. ${ }^{1}$

What stands out in all of Ellen White's counsel on the operation of the church is her seeking to maintain its structure as finely tuned and effective as possible for obtaining success in evangelistic outreach, and she constantly encouraged that which facilitates growth and a sense of urgency with regard to the church propagating the gospel of Christ's Second Coming to the whole world as rapidly as possible. This was to be achieved by the proclamation of the gospel and by the raising up of mostly lay-run churches that were to be

\footnotetext{
'Russell Burrill, Rekindling a Lost Passion (Fallbrook, CA: Hart Research Center, 1999), 52, 53.
} 
loving communities where Christ-like characters were to be exhibited and developed in order that they in turn become evangelistic powerhouses.

Now we turn to some of Ellen White's statements where she explains how churches are to be developed that are an asset to the whole evangelistic enterprise of the Adventist mission in the world rather than churches in constant need of professional care and support by paid ministry, which would be more of a liability.

\section{Importance of the Work of the Church Members}

In every church there is to be established a strong sense of mission and an understanding that the whole mission enterprise of the church is a united responsibility of the pastor and all its members. The part to be played in the church by spiritually gifted members is to be seen as absolutely vital, a task which they in fact pledged to fulfill by their baptismal vow. Theirs is a role which the pastor should not and cannot fill: "God's Spirit convicts sinners of the truth, and He places them in the arms of the church. The ministers may do their part, but they can never perform the work that the church should do. God requires His church to nurse those who are young in faith and experience, to go to them, not for the purpose of gossiping with them, but to pray, to speak unto them words that are 'like apples of gold in pictures of silver."' "God's people are to feel a noble, generous sympathy for every line of work carried on in the great harvest field. By their baptismal vows they are pledged to make earnest, self-denying efforts to promote, in the hardest parts of the field, the work of soulsaving. God has placed on every believer the responsibility of striving to rescue the helpless and the oppressed. ${ }^{2}$

\footnotetext{
${ }^{1}$ White, Evangelism, 352.

${ }^{2}$ Ibid.
} 
Let every believer act his faith, and thus give a testimony to the unbelieving world that he does believe that the end of all things is at hand. "Ye are my witnesses, saith the Lord." ... Those little companies who know the truth, with one voice should bid their minister go to the lost sheep of the house of Israel. Each one should seek to do individual work for another. Not one who has tasted the goodness, the mercy, and the love of God, can be excused from working for the souls of others.'

God's people are called upon to rally without delay under the bloodstained banner of Christ Jesus. Unceasingly they are to continue their warfare against the enemy, pressing the battle even to the gates. And everyone who is added to the ranks by conversion is to be assigned his post of duty. Everyone should be willing to be or to do anything in this warfare. When church members put forth earnest efforts to advance the message, they will live in the joy of the Lord and will meet with success. Triumph always follows decided effort. ${ }^{2}$

\section{United Effort-Essential to Mission Success}

To discover and to facilitate this divinely appointed order of things in the operation of the church is of such vital importance as the successful completion of the task of the church rests on its application:

The leaders in God's cause, as wise generals, are to lay plans for advance moves all along the line. In their planning they are to give special study to the work that can be done by the laity for their friends and neighbors. The work of God in this earth can never be finished until the men and women comprising our church membership rally to the work, and unite their efforts with those of ministers and church officers. ${ }^{3}$

A serious and perhaps unsuspected hindrance to the success of the truth is to be found in our churches themselves. When an effort is made to present our faith to unbelievers, the members of the church too often stand back, as if they were not an interested party, and let all the burden rest upon the minister. For this reason the labor of our most able ministers has been at times productive of little good. The very best sermons may be preached, the message may be just what the people need, and yet no souls be gained as sheaves to present to Christ. ${ }^{4}$

\footnotetext{
'Ellen G. White, "Followers of Christ Will Be Missionaries," Review and Herald, January 8, 1895,1 .
}

\footnotetext{
${ }^{2}$ White, Testimonies for the Church, 7:30.

${ }^{3}$ Ibid., 351.

${ }^{4}$ White, Gospel Workers, 196.
} 


\section{Lay People to Be Allowed to Serve}

These principles of the role of the laity are of divine origin and pastors must step aside and let the real leader of the church, the Holy Spirit, accomplish great things through lay members whom he has empowered to perform divinely appointed duties. Thus a church of spiritually gifted members becomes a support system for the work of the ministers of the church.

God has given "to every man his work." Why is it that ministers and Conference officers do not recognize this fact? Why do they not manifest their appreciation of the help that individual members of the church could give? . . If ministers and men in positions of authority will get out of the way, and let the Holy Spirit move upon the minds of the lay brethren, God will direct them what to do for the honor of His name. Let men have freedom to carry out that which the Holy Spirit indicates.

Frequently the churches are in advance of the ministers who labor among them, and would be in a more prosperous condition if those ministers would keep out of their way, and give them an opportunity to work. The efforts of such ministers to build up the churches only tear them down. The theory of the truth is presented over and over again, but it is not accompanied by the vitalizing power of God. They manifest a listless indifference; the spirit is contagious, and the churches lose their interest and burden for the salvation of others. Thus by their preaching and example, the ministers lull the people to carnal security. If they would leave the churches, go out into new fields, and labor to raise up churches, they would understand their ability, and what it costs to bring souls out to take their position upon the truth. And they would then realize how careful they should be that their example and influence might never discourage or weaken those whom it had required so much hard, prayerful labor to convert to the truth. ${ }^{1}$

\section{The Beneficial Effect of Active Involvement}

Further, this participation in the sharing of the gospel message is a source of abundant spiritual blessing for every participant in that work as the members find encouragement and a help for themselves in helping others. It is in fact a wonderful cure for most of the ailments of the church: "The greatest help that can be given our people is

\footnotetext{
${ }^{1}$ White, Testimonies for the Church, 2:340.
} 
to teach them to work for God, and to depend on Him, not on the ministers. Let them learn to work as Christ worked. Let them join His army of workers and do faithful service for Him."”

A working church is a growing church. The members find a stimulus and a tonic in helping others. I have read of a man who, journeying on a winter's day through deep drifts of snow, became benumbed by the cold, which was almost imperceptibly freezing his vital powers. He was nearly chilled to death, and was about to give up the struggle for life, when he heard the moans of a fellow-traveler, who was also perishing with cold. His sympathy was aroused, and he determined to rescue him. He chafed the ice-cold limbs of the unfortunate man, and after considerable effort raised him to his feet. As the sufferer could not stand, he bore him in sympathizing arms through the very drifts he had thought he could never get through alone.

When he had carried his fellow-traveler to a place of safety, the truth flashed home to him that in saving his neighbor he had also saved himself. His earnest efforts to help another had quickened the blood that was freezing in his own veins, and sent a healthy warmth to the extremities of his body.

The lesson that in helping others we ourselves receive help, must be urged upon young believers continually, by precept and example, that in their Christian experience they may gain the best results....

Let church-members during the week act their part faithfully, and on the Sabbath tell their experiences. The meeting will then be as meat in due season, bringing to all present new life and fresh vigor. ${ }^{2}$

"It is by engaging in earnest work, by hard, painful experience, that we are enabled to reach the men and the women of our cities, to call them in from the highways and the byways of life. But many of our people ... have lost the sense of the value of human souls."” The best medicine you can give the church is not preaching or sermonizing, but planning work for them." ${ }^{.4}$

${ }^{1}$ Ibid., 7:19.

${ }^{2}$ White, Gospel Workers, 198, 199.

${ }^{3}$ Ellen G. White, "Go into All the World," Review and Herald, June 11, 1895, 1.

${ }^{4}$ White, Gospel Workers, 198, 199. 


\section{Must Put New Members to Work Immediately}

To the question when new members should be engaged in active missionary work, White's answer is "as soon as possible!" There is no time to lose as the newly converted have a vivid sense of the reality of God's power and have experienced his wonderful love which they are highly motivated to share with others "Just as soon as a church is organized, let the minister set the members at work. They will need to be taught how to labor successfully. Let the minister devote more of his time to educating than to preaching." "When souls are converted, set them to work at once. And as they labor according to their ability, they will grow stronger. It is by meeting opposing influences that we become confirmed in the faith."

Newly formed churches should quite soon in their experience be encouraged to form yet another new church, and rapid increase in strength and maturity of the members will take place as they engage in work for others: "We should ever leave upon the minds of new disciples an impression of the importance of our mission. As able men are converted to the truth, they should not require laborers to keep their flagging faith alive; but these men should be impressed with the necessity of laboring in the vineyard." "As churches are established, it should be set before them that it is even from among them that men must be taken to carry the truth to others, and raise up new churches; therefore they must all work, and cultivate to the utmost the talents that God has given them, and be

\footnotetext{
${ }^{1}$ White, Testimonies for the Church, 7:20.

${ }^{2}$ White, Evangelism, 355 .

${ }^{3}$ White, Testimonies for the Church, 3:210.
} 
training their minds to engage in the service of their Master."

Their method of sharing should never be argumentative but simply to share the powerful testimony about God's love in Jesus: "None should be forward to enter into controversy, but they should tell the simple story of the love of Jesus. All should constantly search the Scriptures for the reason of their faith, so that, if asked, they may give 'a reason of the hope that is in them, with meekness and fear."',

The Training of Lay People for Service

In order for the members of the church to do successful service they must be trained. To this work the minister must devote time and energy before he ventures into evangelism, and it would be well for him to prioritize this work even higher than his preaching: "In laboring where there are already some in the faith, the minister should at first seek not so much to convert unbelievers, as to train the church-members for acceptable co-operation." "Let the minister devote more of his time to educating than to preaching. Let him teach the people how to give to others the knowledge they have received. ${ }^{4}$ "In every church the members should be so trained that they will devote time to the winning of souls to Christ. ${ }^{5}$ "It is not enough to show how much needs to be done, and to urge the youth to act a part. They must be taught how to labor for the Master. They must be trained, disciplined, drilled, in the best methods of winning souls to Christ. Teach them

\footnotetext{
${ }^{1}$ White, Gospel Workers (1892), 50.

${ }^{2}$ Ibid., 356.

${ }^{3}$ Ibid.

${ }^{4}$ Ibid., 20.

${ }^{5}$ White, Testimonies to the Church, 6:436.
} 
to try in a quiet, unpretending way to help their young companions."”

White emphasizes an important point in how to transmit both skills and motivation to those being trained as she advocates the wise method of teaching and being active in evangelistic work at the same time. It is a matter of keeping the church alive and active and burning for the truth:The minister should not feel that it is his duty to do all the talking and all the laboring and all the praying; he should educate helpers in every church. Let different ones take turns in leading the meetings, and in giving Bible-readings; in so doing they will be calling into use the talents which God has given them, and at the same time be receiving a training as workers. ${ }^{.2}$

Those who are most actively employed in doing with interested fidelity their work to win souls to Jesus Christ, are the best developed in spirituality and devotion. Their very active working formed the means of their spirituality. There is danger of religion losing in depth that which it gains in breadth. This need not be, if, in the place of long sermons, there is wise education given to those newly come to the faith. Teach them by giving them something to do, in some line of spiritual work, that their first love will not die but increase in fervor. ${ }^{3}$

Finally, a statement that summarizes the whole thrust of Ellen White's vision for the church. This describes in fact a whole church-planting movement, the establishing of a center in a certain place and then moving on to repeat the process. But the new church is not to be left destitute but should be educated to be a beacon of light to attract converts to it all the time. Its main purpose is to lift up Christ before humanity. Then the power of the gospel is released in the lives of many who receive him and who in turn are fitted for service to be a blessing to others:

\footnotetext{
${ }^{1}$ White, Gospel Workers, 210.

${ }^{2}$ Ibid., 197.

${ }^{3}$ White, Evangelism, 356.
} 
Place after place is to be visited; church after church is to be raised up. Those who take their stand for the truth are to be organized into churches, and then the minister is to pass on to other equally important fields.

Just as soon as a church is organized, let the minister set the members at work. They will need to be taught how to labor successfully. Let the minister devote more of his time to educating than to preaching. Let him teach the people how to give to others the knowledge they have received. While the new converts should be taught to ask counsel from those more experienced in the work, they should also be taught not to put the minister in the place of God. ...

The power of the gospel is to come upon the companies raised up, fitting them for service. Some of the new converts will be so filled with the power of God that they will at once enter the work. ${ }^{1}$

\section{Summary}

We have studied Ellen G. White's counsel on the purpose and function of the Adventist church and seen that she understands it, in the light of Rev 14, to be the embodiment of God's faithful remnant in earth's final hour charged preeminently with the urgent task of completing world evangelization. What are then the main points of her counsel for the church at this time in history?

Ellen G. White has a very high view of the role of the church as God's channel of truth and grace on earth which she regards as its sacred trust. She also sees, much in line with the concept we have noticed in Matthew's Gospel and in Rev 14, the church to be a showcase on earth of the power of God's grace to transform lives.

White underlines the importance of solid and faithful church servant-leadership by the clergy but is forceful in her comments against dictatorial tendencies of leaders which stand in the way of the participation in the life and work of the church by all its members. All are to be allowed to contribute through their particular gifts of the Spirit which White emphatically believes all to possess. Thus the success of the church is determined by its

\footnotetext{
${ }^{1}$ White, Testimonies for the Church, 7:20.
} 
willingness to let the Spirit of unity prevail in the church and by letting all its members contribute in their divinely inspired way in order to accomplish the church's divine purpose.

Evangelism has a clear priority in the program of the church, as only by evangelizing does it obey the commission and charge of its founder. Only this legitimizes its existence. This calls for a division of labor in the church and White advocates that pastors, mindful of the primacy of evangelism, devote their time among the unconverted and to the raising up of new churches. Within the churches they should share the burden of spiritual nurture and the proving of care with the lay leaders and the membership as a whole. The flock needs to be fed, but still the proportions must be right. White's advice that sermons should be short and not even necessary every Sabbath is made in the interest of pastors who tend to use much of their time preparing long messages for those who should already be engaged in working for others. This they do at the expense of more effective shepherding in the visitation program where people are supported, feelings are touched, and real needs are dealt with.

Finally, White underlines that the worship services of the church must be useful and inspiring. They must motivate and equip the participants in their practical Christianity and witnessing for Christ, an objective that must influence every part of the service. To achieve this she advocates short sermons and to the point, great openness and spontaneity in the worship where lay people have an opportunity to take part and to bring a testimony. Also here the pressing need for the church is the active involvement of its lay people in the work, something which also aids their own spiritual development. The general rule seems to be that lay people work within the church while the pastoral staff concentrates on the 
unconverted. Thus new members should immediately be engaged in activities of the church according to their spiritual gifts, but in order for this to function, effective training must constantly take place.

Many of the elements thus emphasized by Ellen G. White were reiterated in literature in a forceful way a few decades later by the proponents of the Church Growth Movements. To the exploration of these we will now turn. 


\section{CHAPTER III}

\section{PRINCIPLES AND PRAXIS OF CHURCH GROWTH: A REVIEW OF LITERATURE}

\section{Introduction}

The aim of this project is to analyze and evaluate the progress of the Adventist church in Iceland from its inception at the end of the nineteenth century until the present and, while realizing it is God's church and its future is in his hands, to suggest ways in which to revitalize it so as to make it more effective in achieving its aim of evangelizing the people of Iceland. The purpose of this chapter is to consider the main contributions of the key adherents of church growth theory and praxis with view to assessing its relevance to the above task and to relate it to contemporary cultural developments.

\section{The Church Growth Movement}

\section{Beginnings of the Church Growth Concept-Donald McGavran}

Church Growth, as a modern-day phenomenon, was advanced through the work of Donald Anderson McGavran (1897-1991), largely deriving from his missionary experience, he having served as a third-generation missionary in India on behalf of the United Church Missionary Society for thirty-two years (1923-1955). ${ }^{1}$ McGavran, troubled

${ }^{1}$ For a detailed discussion of Donald McGavrans's missiology, especially viewed in relation to his own church affiliation with the Christian Church (Disciples of Christ) and missionary experience, see Sakari Pinola, Church Growth: Principles and Praxis of Donald McGavran's Missiology (Aabo, Sweden: Aabo Akademis Forlag, 1995). Pinola suggests that the Disciples' "theology without creeds" approach and McGavran's own pursuit of not seeking any clear commitment to a particular confessional theology have 
by discouraging evangelistic results of missionary work in India, and posing the question

"How do you account for growth and non-growth in identical situations where

presumably missionaries have been equally faithful?"1 became inspired by the work of

two men, an Anglican former missionary to China, Roland Allen, ${ }^{2}$ and Methodist bishop,

J. Waskom Pickett. ${ }^{3}$ Through the influence of these men the question of purpose and

praxis of mission took a new course in McGavran's mind and his first books, Bridges of

God (1955) and How Churches Grow (1957), brought his revolutionary concepts of

highly receptive people, ${ }^{4}$ people movements ${ }^{5}$ (group conversions), and "that people

aided him in being accepted by many theological traditions while this has also brought many charges of him being too theologically shallow. Pinola, 27, 33, 86, 259, 260. For further information on McGavran as a person see Thom S. Rainer, The Book on Church Growth: History, Theology, and Principles (Nashville, TN: Broadman Press, 1993), and C. Peter Wagner, "Donald A. McGavran: A Tribute to the Founder," in Church Growth: State of the Art, ed. C. Peter Wagner and others (Wheaton, IL: Tyndale House, 1986), 1519.

'A. R. Tippett, "Portrait of a Missiologist by His Colleagues," in God, Man, and Church Growth, ed. A. R. Tippett (Grand Rapids, MI: Eerdmans, 1973), 21, 22. "Pickett's survey showed that the 134 mission stations in Mid-India (where McGavran then served) grew only 12 percent in 10 years. Appalled at the slow growth and few conversions McGavern began researching into church growth in his area and looking at statistics as far back as 1918." Rainer, 20.

${ }^{2}$ Allen's major books were Missionary Methods: St. Paul's and Ours (1912), Pentecost and the World (1917) and The Spontaneous Growth of the Church (1927). McGavran claimed Missionary Methods to be "one of the most influential documents on mission methods ever written" (Donald McGavran, Understanding Church Growth [Grand Rapids, MI: Eerdmans, 1970], 339).

${ }^{3}$ Pickett's book, Christian Mass Movements in India (New York, NY: Abingdon Press, 1933), was a result of an extensive survey made in India, Burma, and Ceylon. In the foreword to the book John R. Mott states that half of the Roman Catholics and no less than 80 percent of Protestants in India were descendants and products of Christian mass movements (Pickett, 5, 313).

4"serhaps the dearest church growth principle that has emerged from Pickett to McGavran to modern church is the principle of receptivity. Receptive people are those who are most likely to hear the gospel message positively as a result of personal crisis, social dislocation and/or the internal working of the Holy Spirit." Rainer, 30.

${ }^{5}$ A concept closely related to Pickett's "mass movements." McGavran states his principle of people movements thus: "People become Christians as a wave of decision for Christ sweeps through the group mind involving many individual decisions but being far more than merely their sum. This may be called a chain reaction. Each decision sets off others and the sum total powerfully affects every individual. When conditions are right, not merely each sub-group, but the entire group concerned decides together" (Bridges of God [New York, NY: Friendship Press, 1955], 13). This thinking opposes the so-called "mission station approach" which called for conversions based on the Western individualistic view, and 
become Christian faster when the least change of race or clan is involved,"' the later homogeneous unit principle, ${ }^{2}$ to the attention of missiologists and church leaders worldwide.

In 1970 McGavran published his definitive work, Understanding Church Growth, ${ }^{3}$ where he shared his mature thinking on church growth theory. The essential elements of his legacy can be summarized in the following way: First, he possessed a strongly held conviction that "the Christian mission is twofold, first, the conversion of the lost; second, a strategy for discipleship,"4 thus his church-centered mission strategy. Second, he believed that by the neglect of biblical principles and due to unbiblical approach and methods resources were misused that could be better devoted to propagating the faith. Third, he urgently advocated the task of reaping the harvest and his optimistic pragmatism in accomplishing this commission by prioritizing, applying scientific as well as biblical methods, and measuring the results relentlessly which is reflected in the growth of the

produced extremely slow church growth, social dislocation of converts, and a perception of the mission station as being an end in itself rather than means to an end (Pinola, 239, 240).

${ }^{1}$ McGavran, Bridges of God, 23.

2"McGavran's [homogeneous] principle that "men like to become Christians without crossing racial, linguistic or class barriers" is related to his way of seeing mankind as a kaleidoscopic mosaic, with each piece, although having much in common with others, being in many ways unlike others. He calls the pieces of this vast mosaic homogeneous units and defines homogeneous units as 'a section of society in which all the members have some characteristic in common.' Homogeneous units can be defined either politically, geographically, culturally, ethnically, economically, educationally or linguistically." McGavran, Understanding Church Growth, 85, quoted by Pinola, 228.

${ }^{3}$ Understanding Church Growth was published again in 1980, revised by McGavran, and in a third edition, revised by C. Peter Wagner, in 1990.

${ }^{4}$ Rainer, 28. See "discipling and perfecting" (McGavran, Understanding Church Growth, 123- 
church. In 1961 he established his Institute for Church Growth ${ }^{1}$ in Eugene, Oregon, and reestablished it in 1965 at the Fuller Theological Seminary in Pasadena, California, and became the founding dean of the School of World Missions there. This remains the institutional center of the movement.

\section{Voices of Criticisms}

The church growth school of thought did from its inception meet substantial opposition due to its concept of numerical church growth, ${ }^{2}$ and its narrow conception of salvation as a vertical relationship ${ }^{3}$ and of mission as evangelism. This coincided with the heated, prolonged, so-called evangelical-conciliar debate, ${ }^{4}$ roughly between evangelical missiologists and theologians and their ecumenical counterparts in general and the staff of the World Council of Churches in particular where church growth promoters were quite

${ }^{1}$ McGavran sought by this enterprise to remedy what he called a "disastrous vacuum in knowledge and training [which] handicaps the entire missionary enterprise." Donald McGavran, "Institute of Church Growth," International Review of Missions 50 (1961): 431-432.

${ }^{2}$ The Church Growth Movement insists that evangelization is incomplete until the person has become a responsible disciple of Christ and looks at active church membership as evidence of responsible discipleship. Thus effective evangelism can be measured by numerical church growth. See McGavran, 24 . For criticism from the Reformed perspective see John M. L. Young, "The Place and Importance of Numerical Church Growth," in Theological Perspectives on Church Growth, ed. Harvie M. Conn (The den Dulk Foundation, 1976), 57-73. He correctly urges that "the goal of added numbers must not be absolutized. They are not the only valid measurement for growth." Church growth advocates point out "numbers stand for people." C. Wayne Zunkel, Church Growth Under Fire (Scottsdale, PA: Herald Press, 1987), 120-131, Paul W. Powell, The Nuts and Bolts of Church Growth (Nashville, TN: Broadman Press, 1982), 11, 12.

${ }^{3}$ Bosch points out that salvation is never salvation out of the world (salus e mundo) but always salvation of this world (salus mundi). Bosch, Transforming Mission, 398.

${ }^{4}$ This crucial, extensive debate dealt with the nature of mission, its evangelistic vs. its cultural mandate, the "vertical" vs. the "horizontal" dimensions of the gospel. In the minds of the ecumenical segment "mission was primarily concerned with the doing of God's justice in the world and not primarily with increasing the membership of the church. ... [They] accepted a definition of mission that identified it primarily with action for humanization in the secular life of the world." Lesslie Newbigin, The Open Secret, rev. ed. (Grand Rapids, MI: Eerdmans, 1995), 8, 9. For further and comprehensive treatment of this debate see Donald McGavran, ed., The Conciliar-Evangelical Debate: The Crucial Documents 1964-1976 (Pasadena, CA: William Cary Library, 1977). 
prominent participants. ${ }^{1}$ Further, church growth proponents were charged with insufficiently exact hermeneutics. ${ }^{2}$ Then McGavran was heavily criticized on ethical grounds for his thorough-going pragmatism, ${ }^{3}$ and on procedural and exegetical grounds for his "soft peddling" conversions by separating "discipling" and "perfecting" in the conversion process, ${ }^{4}$ and the sentiment has prevailed that the emphasis on growth in churches has led to compromise in areas of conservative spirituality. ${ }^{5}$ Also scholars took issue with the church growth school of thought on grounds of its use of anthropology with its inherent cultural relativism. ${ }^{6}$ Finally, some of the greatest criticism of church growth

${ }^{1}$ For a discussion on a crucial aspect of the debate, namely the church-centered emphasis of mission which characterized evangelical and church growth missiology over against the world-centered missiology characterizing ecumenical missiology, rising especially from such missiologists as J. C. Hoekendijk, see Charles van Engen, The Growth of the True Church (Amsterdam: Rodopi B.V., 1981), 305-323.

${ }^{2}$ Shenk warns against "a particularly casual attitude toward biblical materials." Wilbert R. Shenk, "Church Growth Study: A Bibliography Overview," in The Challenge of Church Growth: A Symposium (Elkhart: IN: Institute of Mennonite Studies, 1973), 22, quoted in Harvie M. Conn, "Looking for a Method: Backgrounds and Suggestions" in Exploring Church Growth, ed. Wilbert R. Shenk (Grand Rapids, MI: Eerdmans, 1983), 85. And van Engen states: "Too often the [Church Growth] Movement seems to use texts simply to shore up Church Growth theory" $(356,357)$.

${ }^{3}$ McGavren's literal acceptance of Christ's command to make disciples drove him to reject a mere "search theology" for "harvest theology" (McGavran, Understanding Church Growth, 23-30) where his watchword was accountability shown in evaluating numerical results. This, the critics complained, generated high pressure inclined to produce mere statistical victories (Rainer, 35). For further discussion see van Engen, 454-473.

${ }^{4}$ McGavran separated "discipling" (the charge "to make disciples" in the Great Commission, Matt 28:20) and "teaching them all things" which he called "perfecting" when the community as a whole began to live a thoroughly Christian way of life (McGavran, Understanding Church Growth, 123-130).

McGavran's priority of "discipling" over "perfecting" was criticized on procedural, exegetical and ethical grounds (Rainer, 35). See also Charles R. Taber, "Contextualization" in Exploring Church Growth, ed. Wilbert R Shenk (Grand Rapids, MI: Eerdmans, 1983), 126, 127.

${ }^{5}$ Hadaway verbalizes a common notion that growth requires sacrifices: "the spiritual well-being of members, sacrificing worship for entertainment, and substituting promotion for ministry." But he points out that in many surveys this has been disproved: "Adults in growing churches tend to indicate more growth in faith on average than do adults in churches which are not growing." C. Kirk Hadaway, Church Growth Principles: Separating Facts from Fiction (Nashville, TN: Broadman Press, 1991), 11, 12.

${ }^{6}$ Taber sees the Church Growth missionary methodology built on certain ideas derived from structural-functional anthropology which suggests that "cultural givens" take on permanence. This cannot but undermine the hope for transformation which is the hope of the gospel. Taber, 126, 127. 
theory by many authorities on missiology stemmed from the homogeneous unit principle ${ }^{1}$ which McGavran emphasized forcefully in Understanding Church Growth in 1970.

\section{Subsequent Developments}

While McGavran's church growth theories were mainly focused on the mission in the Third World, C. Peter Wagner, a disciple of McGavran and a senior lecturer at the Institute, emerged in the 1970s as an able and prolific propagator and applicator of church growth concepts in the Western setting. ${ }^{2}$ Delos Miles ${ }^{3}$ points out some factors that were instrumental in shaping the Church Growth Movement during this decade: (1) The development of evangelical ecumenicity, ${ }^{4}(2)$ the relationship between superchurches, large, aggressive and growing churches, and the movement, (3) the era coincided with the era of lay-witness training, (4) church growth emphasized the role of engaging all believers to do the work of ministry and thus the lay renewal movement found an ally in the Church Growth Movement, (5) the Neo-Pentecostal impact on church growth can be

\footnotetext{
${ }^{1}$ Padilla does not find any biblical grounds for the HUP. On the contrary, nowhere in the Acts account is "segregated missions strategy" to be found, which is an account of "breaking down barriers" and of a church that "grew across cultural barriers." This was not seen as an "optional blessing to be enjoyed whenever circumstances were favorable ... but as essential to Christian commitment." He thus sees the HUP as a result of a "failure to take biblical theology seriously" and "it has become a missiology tailor made for churches and institutions whose main function in society is to reinforce the status quo." $\mathrm{C}$. René Padilla, "The Unity of the Church and the Homogeneous Unite Principle," in Exploring Church Growth, 285-302.

${ }^{2}$ Rainer, 51-60; Wagner, Church Growth: State of the Art, 272. "C. Peter Wagner has published over 700 works since 1956, including almost 40 full length books." Rainer, 57 . Early influential books by Wagner on church growth are: Your Church Can Grow (1976), Your Church Can Be Healthy (1979), and Our Kind of People: Ethnic Dimensions of Church Growth in America (1979).

${ }^{3}$ Delos Miles, Church Growth: A Mighty River (Nashville, TN: Broadman, 1981), chapter 2.

${ }^{4}$ This evangelical ecumenicity is best exemplified in the International Congress on World Evangelization in 1974 in Lausanne, Switzerland, and its predecessor, the World Congress on Evangelization, Berlin, 1966. "Lausanne drew evangelicals together, including church growth leaders. ... Of particular importance to the Church Growth Movement in the new ecumenism was the easily accessible platform church growth leaders now had." Rainer, 42-43. Wagner took active part in forming the Lausanne Covenant and this process was instrumental in effecting a change in church growth theology.
} 
traced to this era, (6) and also the Sunday School Movement and (7) the Keswick

Movement which emphasized spiritual growth both impacted the development.

Wagner advocated the homogeneous unit principle, ${ }^{1}$ but a shift took place in the early 1980s with his publication of Church Growth and the Whole Gospel ${ }^{2}$ where he sought to respond to earlier criticism of the movement. It was written in a conciliatory spirit admitting some former theological and hermeneutical deficiencies in the presentation of church growth theory, now strongly affirming the cultural mandate in mission while still allowing the evangelistic mandate a clear priority, ${ }^{3}$ and reducing the role of the homogeneous unit principle in the presentation of church growth theory. ${ }^{4}$

\section{Theological Considerations}

According to McGavran "church growth is basically a theological stance." ${ }^{, 5}$ But in his mind the overshadowing and most important task of the church is to multiply itself

'See C. Peter Wagner, Our Kind of People: The Ethical Dimensions of Church Growth in America (Atlanta, GA: John Knox Press, 1979). The book is based on Wagner's doctoral dissertation from the University of Southern California. Tom Nees reviews Our Kind of People and says that church growth has a theology of evangelism "which reduces initial Christian commitment to an inoffensive appeal avoiding the suggesting that to become a Christian one must turn from a social order that perpetuates injustice." Sojourners, February 1980, 27.

${ }^{2}$ C. Peter Wagner, Church Growth and the Whole Gospel: A Biblical Mandate (San Francisco, CA: Harper and Row, 1981).

${ }^{3}$ Wagner still held to the primacy of the evangelistic mandate in spite of great protest from such South American theologians as Orlando Costas and René Padilla and also from Alfred Krass who called for a holistic approach. Wagner's arguments were both theological and pragmatic: (1) The biblical priority of soul over body (Matt 10:28), (2) Winning people he claimed was instrumental in massive social reform (referring to e.g., Rufus Anderson), (3) The reversing of priorities could lead to the collapse of the Christian movement, pointing to the fate of the Student Volunteer Movement: "The failure to grasp the priority of evangelism is a death blow to a Christian movement" (Rainer, 156).

${ }^{4}$ Wagner modified his earlier view by stating that "the homogeneous unit principle [is] a penultimate dynamic, not an ultimate ideal." Church Growth and the Whole Gospel, 166. See also Rainer, $58-59,155-159$.

\footnotetext{
${ }^{5}$ McGavran, Understanding Church Growth, 8.
} 
among all nations in order to accomplish what God has entrusted to it: "the task of taking the gospel of salvation through Christ across all cultural, racial and linguistic barriers to the peoples of this world." This must be done as an expression of obedience to the Gospel Commission of Matt 28:18-20. Or, as McGavran put it: "God's obedient servants seek church growth, not as an exercise to improve humanity, but because the extension of the church is pleasing to God. Church growth is faithfulness."

This all-important contribution of church growth, born in an interdenominational milieu, was not to be encumbered by shades of theological interpretations of different churches, thus the proponents of the Church Growth Movement have "avoided voicing their own theological convictions" with no direct bearing on church growth. ${ }^{3}$ This is not to say that the Church Growth Movement downplays its theological foundations, as is brought out by Wagner:

Although interdenominational in scope, this [the church growth] approach operates within a set of theological presuppositions that decisively influence its goals and methodologies. In broad brush strokes this can be described as an evangelical theology. It takes seriously the sovereignty of God, the lordship of Jesus Christ, the absolute authority of the scriptures, the reality of sin and eternal judgement, the divine will that all men and women be reconciled to God through Jesus Christ, the need for a born-again experience, and the requirement placed on all believers to share their faith. ${ }^{4}$

'Erich W. Baumgartner, "Towards a Model of Pastoral Leadership for Church Growth in GermanSpeaking Europe" (Ph.D. dissertation, Fuller Theological Seminary, 1990), 75, 76.

${ }^{2}$ McGavran, Understanding Church Growth, 6. This conviction is clear in McGavran's three main books, Bridges of God (New York, NY: Friendship Press, 1955), How Churches Grow (New York, NY: Friendship Press, 1957), and Understanding Church Growth (Grand Rapids, MI: Eerdmands, 1970, 1980, 1990).

${ }^{3}$ McGavran, Understanding Church Growth, 8.

${ }^{4}$ Wagner, "Church Growth Research: The Paradigm and Its Applications," in Understanding Church Growth and Decline 1950-1978, ed. Dean R. Hoge and David A. Roozen (New York, NY: The Pilgrim Press, 1979), 270. 
Faithfulness to this God-given task is not attained only by engagement in the delivering of the Christian message, but by obtaining actual results. "Search" for the lost is a good beginning but the job is not done until the lost have been found. ${ }^{1}$ Tangible, measurable growth must thus be the goal in missions. Thus McGavran defines mission as "an enterprise devoted to proclaiming the good news of Jesus Christ, and to persuading men and women to become his disciples and responsible members of his church." The intense emphasis on numerical growth has fostered the notion within the movement right from the start that it is permissible to consult non-religious disciplines of enquiry, such as the social and behavioral sciences, if those principles are not unbiblical and can contribute to growth. ${ }^{3}$ The movement does not lay claim on having come up with new conclusions but "the movement's particular contribution to the practical knowledge of ecclesiastical growth dynamics has been its systematization of bits and pieces of data from theology and the social sciences into a coherent whole that provides useful handles for church practitioners."

I"In McGavran's books, such as Bridges of God (1955), How Churches Grow (1959), and Understanding Church Growth (1970) he basically states that churches have one main job - to multiply themselves. In other words, the purpose of the church is evangelism and everything must be subordinated to it. Today Wagner's theology, which is representative of church growth ecclesiology, has departed from the narrow concept of the purpose of the church, although evangelism remains the primary purpose." Rainer, 149.

${ }^{2}$ McGavran, Understanding Church Growth, 24. "McGavran wanted evidence that salvation was taking place, that people were coming to Christ. ... Jesus said, "By their fruit you will recognize them" (Matt 7.16)... . McGavran took another but fallible approach. Salvation would be "numbered" by "responsible church membership." .. Thus the Church Growth Movement arose where salvation became quantifiable and churches became accountable." Rainer, 142, 143.

3،"The findings of social scientific research are used by the church growth movement when such findings are perceived to contribute to the task. To date, the discipline that has made the most direct contribution to the movement has been cultural anthropology. However, important input has also been received from social psychology, communications, and marketing research." C. Peter Wagner, Strategies for Church Growth (Ventura, CA: Regal Books, 1987), 271.

${ }^{4}$ Ibid. 
The movement is thus above all "task-oriented ... deeply rooted in theological traditions" but not "doing theology for theologies sake."1 Thus Wagner can define church growth approach to mission as "all that is involved in bringing men and women who do not have a personal relationship to Jesus Christ into fellowship with Him and into responsible church membership"2 (emphasis supplied).

\section{Church Growth Principles-Fundamental Concepts}

The main purpose of the Church Growth Movement is to discover and to promote growth-enhancing strategies for churches. Methods that have fostered numerical and qualitative increase or promoted the health of churches in certain locations are then analyzed and tested with the view to deducing from them some basic norm which might with further testing be elevated to the position of universal principle. "The church growth research paradigm does not operate in a vacuum. A decade of investigation has accumulated enough data to formulate principles that seem not to be culturally specific, but which have cross-cultural validity." ${ }^{3}$

Most church growth thinking and literature revolves around such principles of church growth, defined as: "worldwide truths which, when properly applied, along with other principles, contribute significantly to the growth of the church." ${ }^{.4}$ Many of these principles have emerged after many years of analytical work and arisen from the

${ }^{\mathrm{I}}$ Ibid.

${ }^{2}$ Wagner, Strategies for Church Growth, 114.

${ }^{3}$ Wagner, "Church Growth Research: The Paradigm and Its Applications," 275.

${ }^{4}$ Wagner, Church Growth: State of the Art, 284. On how to discover church growth principles, see Donald McGavran and Winfried Arn, Ten Steps for Church Growth (San Francisco, CA: Harper and Row, 1977), 15-23. 
inclination of church growth proponents to work in a manner as exact as possible. I will summarize the most essential principle here below but first seek to shed light on standardized procedures and terminology in church growth which have been developed by leading authorities in order to achieve clarity, exactness and uniformity in expression and in their endeavor to introduce scientific approach to their work.

\section{The Relationship of Evangelism and Church Growth}

Church Growth theory differentiates between church growth and evangelism where church growth is the broader discipline including the investigation of "the nature, expansion, planting, multiplication, function, and health"1 of churches while evangelism is confined to the presentation of the gospel toward the goal of making disciples of Jesus Christ. ${ }^{2}$ Three views of evangelism are recognized:

1. Presence Evangelism (P-1), the impact of the Christian witness is confined merely to the way of life of Christian people as they live the gospel before the lost, or are an "anonymous witness."

2. Proclamation Evangelism (P-2), a view where the evangelist is concerned with the announcement of the gospel in word and deed but does not take responsibility for the results.

3. Persuasion Evangelism (3) refers to an attitude in evangelism that "does not

${ }^{1}$ Wagner, Strategies for Church Growth, 114.

${ }^{2}$ The Lausanne covenant defines evangelism thus: "To evangelize is to spread the good news that Jesus Christ died for our sins and was raised from the dead according to the Scriptures . . . and that as the reigning Lord he now offers the forgiveness of sins and the liberating gift of the Spirit to all who repent and believe. Our Christian presence in the world is indispensable to evangelism, and so is that kind of dialogue whose purpose is to listen sensitively in order to understand. But evangelism itself is the proclamation of the historical, biblical Christ as Savior and Lord, with a view to persuading people to come to him personally and so be reconciled to God." J. D. Douglas, Let the Earth Hear His Voice (Minneapolis, MN: World Wide Publications 1975), 4. 
regard a person as evangelized unless and until he or she becomes a disciple of Jesus Christ and a responsible member of a local church"1

These three approaches are not mutually exclusive. Wagner sees them as parts of a composite whole of evangelism in laying a foundation (presence), erecting a structure (proclamation), and finally completing the project by the forming of responsible members (persuasion). ${ }^{2}$

\section{Sources of Growth}

Church Growth theory works with three forms of growth of the local church:

1. Biological growth, which is generated from within the families of the local church as children of members join the church.

2. Transfer growth, as believers withdraw their membership from one church and join another.

3. Conversion growth which is generated by sharing the gospel with unbelievers who then accept Christ and become members. Evangelism focuses primarily on conversion growth as this in a real sense achieves expansion of the kingdom or God.

\section{Classification of Evangelism}

Ralph Winter has suggested terminology to specify cultural distance to be crossed before the message had been received in order to form effective evangelistic strategies within different cultural contexts. Evangelism is thus basically of four different kinds:

Evangelism Zero (E-0), Leading people to a commitment to Jesus Christ who are

\footnotetext{
'Wagner, Strategies of Church Growth, 122.

${ }^{2}$ Ibid.
} 
already church members.

Evangelism One (E-1), Leading people to Christ who are members of the same cultural group.

Evangelism Two (E-2), Cross-cultural evangelism involving a cultural group similar to one's own.

Evangelism Three (E-3), Cross-cultural evangelism of a culture dissimilar from one's own culture.

\section{Types of Church Growth}

C. Peter Wagner has identified four types of numerical growth:

Internal Growth, growth in quality as members mature in spirituality and quality of their Christian life in the church. (Thus E-0 evangelism is included here as when unconverted church members are born again the quality of the church improves.)

Expansion Growth, growth of the local church as it increases in size by influx of people from the outside either by conversion or transfer.

Extension Growth, growth effected by a church involved in starting a new church within its own cultural context (i.e., applying E-1 evangelism); thus synonymous with church planting.

Bridging Growth, planting a church in a different culture from the one of the parent church involving E-2 and E-3 evangelism.

An Interpretive Framework for Understanding Patterns of Church Growth and Decline

Church growth is caused by a complex interplay of many factors. According to Wagner: "Simply put, church growth is complex. There is no way it can be reduced to a 
simple formula." Then Roozen and Carroll state: "Study after study reaches the same conclusion: There is no single cause or simple pattern of causes related to church growth or decline. Rather, growth or decline involves a complex pattern of multiple and often interacting factors."

The Hartford working group then introduce "a framework for organizing and interpreting the wide variety of factors that contribute to church growth or decline"3 as a result of the interplay of four basic sets of factors:

1. National contextual factors, functioning at a national level, and are thus external to the church over whom the church has little or no control.

2. National institutional factors, representing factors within the church but whose control is located at the national level.

3. Local contextual factors, representing characteristics of the local community of a particular church over which the congregation has little control.

4. Local institutional factors, representing factors internal to the local congregation, those characteristics and structures of a local church that attract or dissuade membership and participation.

Thus Roozen and Carroll point out that "the growth or decline of a local

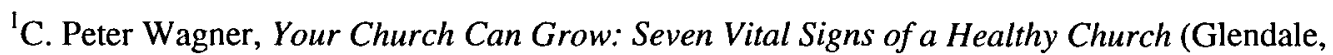
CA: Regal Books, 1976), 26, quoted in David A. Roozen and Jackson W. Carroll, "Recent Trends in Church Membership and Participation: An Introduction," in Understanding Church Growth and Decline: 1950-1978, ed. Dean R. Hoge and David A. Roozen (New York, NY: Pilgrim Press, 1979), 38, 39.

${ }^{2}$ Roozen and Carroll, 39.

${ }^{3}$ A group of academic and church researchers consulted from 1976-1978 at the initiative of the Hartford Theological Foundation with the purpose of understanding mainline and Protestant church membership and participation since 1950. This was done in reaction to a rather sudden halt in growth and a significant decrease in church attendance of most mainline churches in the 1960s and 1970s.

Understanding Church Growth and Decline: 1950-1978, edited by Dean R. Hoge and David A. Roozen, is a compilation of papers presented by members of the working group.
} 
congregation is dependent upon the impact of broad social and cultural forces, the impact of denominational resources and polity, and the impact of local contextual and local institutional factors." According to C. Peter Wagner the local institutional factors seem to be the most influential in the local church. ${ }^{1}$ Then he would add a fifth factor not included in the framework:

A fifth factor has not been discussed by the Hartford working group. ... This factor is the sovereign and nonsociological work of the Holy Spirit. The Holy Spirit uses sociological factors but is not restricted by them, at least according to the theological assumptions of the church growth movement. This, in itself, increases the complexity of understanding ecclesiastical growth trends. ${ }^{2}$

\title{
Church Growth Principles--Strategies for Growth
}

\author{
Signs of Church Health and Disease
}

According to C. Peter Wagner ${ }^{3}$ church health and church growth are closely associated. If a church is fully healthy, it will grow. Conversely, if a church is not growing in membership, there is probably something wrong with its health. He has identified the following "church diseases" that churches need to be able to detect and safeguard against if possible.

1. Ethnikitis is a problem caused by local contextual factors of changing

\footnotetext{
'When commenting on the framework of Roozen and Carroll, Wagner stated: "The above order appears to move from the least to the most significant growth factors." He further comments: "There is some debate among researchers as to the relative importance of institutional and contextual factors on the local level. I would rank local institutional factors higher, but only slightly higher, than local contextual factors as an influence in congregational growth or decline... . Many, probably the majority, of growth problems can be corrected by appropriate decisions and action on the part of the congregation." Wagner, "Church Growth Research: The Paradigm and Its Applications," 275, 276.

${ }^{2}$ Ibid., 276.

${ }^{3}$ See C. Peter Wagner, The Healthy Church (Ventura, CA: Regal Books, 1996); idem, "Church Growth Research: The Paradigm and Its Applications," 270-287.
} 
community in which the church finds itself which will prove fatal to the church. The cause is that the people of the neighborhood, who started the church, are moving to other locations and commute for services. And a new kind of people move in and the church more and more becomes an island of one people in the midst of another. The solution could be to face the facts by making a transition of congregation to the new people group and thus the old congregation dies with dignity.

2. Ghost Town (Old Age) Disease is terminal like ethnikitis and is caused by a disintegrating community. This is normally a rural problem which is not just due to a high age profile (though that often is the case at a late stage). The development often takes the form of population decline until schools close, businesses move out, and finally churches close. The church's best option is to accept the situation and close with dignity.

3. People Blindness is caused by lack of recognition of significant cultural difference that separates peoples into groups in the church. This happens when it is falsely assumed that a church can effectively attend to all kinds of people. In extreme cases a type of "sociological tissue rejection" occurs as a church chooses disintegration rather than receiving large groups perceived by the congregation as incompatible.

4. Hypercooperativism is arrested evangelism of a church based on a common misunderstanding that the more cooperation there is between denominations the more effective evangelism is going to occur. It often is the fact that when churches are engaged in a high level of interdenominational cooperation less evangelism happens. Thus areawide ecumenical efforts are not likely to create church growth.

5. Koinonitis is fellowship overdone ("spiritual navel-gazing") which will kill the church if it goes unrecognized. Wagner sees it in two forms: (a) "Fellowship 
inflammation"--members are so occupied in looking after each other that they lose the vision of outsiders yet to believe, thus developing an "evangelistic myopia," (b) "Fellowship saturation"-when the fellowship groups gets too large (100-150) which leads to plateau. Unless they are divided, growth is stunted.

6. Sociological Strangulation is a disease specific for growing churches mainly relating to the overfilling of the church hall or the parking space. If the church hall is 80 percent full, sociological strangulation sets in which will inhibit further growth.

7. Arrested Spiritual Development happens when church members fail to mature in their spiritual life. Church growth will ordinarily suffer in cases of low level of faith, prayer, doctrinal conviction, biblical knowledge, and morality within a church. Some churches may grow for a time as social clubs, but people are mostly attracted to churches with decisive teaching, high moral standards, and the felt presence of the Holy Spirit.

8. Saint John's Syndrome is named after John's description in Rev 2 and 3 of the churches, especially the one in Laodicea, a second-generation, lukewarm church experiencing material affluence but spiritual stagnation. The cycle within churches of rise, plateau, and decline is inevitable and no cure is known but to continually bring renewed first generation into the membership.

\section{Signs of Church Vitality-Survey of Baptist Churches in England}

Wagner published the following list of what he saw as the seven most important elements in the operation in each church for it to remain healthy. ${ }^{1}$ Paul Beasley-Murray and Alan Wilkinson put these principles to the test within the English context. I will first

\footnotetext{
'C. Peter Wagner, Your Church Can Be Healthy (Nashville, TN: Abingdon, 1979).
} 
review the list, and then summarize the findings of the English study.

\section{Seven Vital Signs}

1. The pastor. The Pastor should be a possibility thinker whose dynamic leadership must catalyze the entire church into action for growth.

2. The laity. The church should have a well-mobilized laity which has discovered, developed, and is using all the spiritual gifts for growth.

3. Church size. The church should be big enough to provide the range of services that meets the expectations of the members.

4. Structural balance. The three significant components of the infrastructure of a church-celebration (the membership group), the congregation (the fellowship group), and the cell (the spiritual kinship group)-should be present and active.

5. The homogeneous unit. The church must concentrate its work mainly for one kind of people.

6. Effective evangelistic methods. The church should be using evangelical methods that are known to work.

7. Properly arranged priorities. The church must realize that its most important function in the community is religious rather than social.

\section{Survey of Baptist Churches-Paul Beasley-Murray and Alan Wilkinson}

Paul Beasley-Murray and Alan Wilkinson' tested these vital signs on 330 Baptist churches in England which had a membership of over 50 as to whether they were growth

\footnotetext{
'Paul Beasley-Murray and Alan Wilkinson, Turning the Tide (London: Bible Society, 1981), especially chapter 4 .
} 
promoting in the English context. Their findings, though over twenty years old, are still valid and could be relevant and informative to the situation in Iceland. I will thus note shortly the main findings of the survey.

1. The minister. With regard to the attitude and role of the minister, inquiring both about the age of the minister and the length of his tenure, the survey showed that a minister in his thirties having served only about five to ten years in the ministry is the one most likely to experience growth. But on the other hand, long-time service in one church (5-10 years and 25+) produces bias towards growth. Second, inquiring into what particular strengths in a minister (preaching, pastoral care, administration, or vision/leadership) were most related to growth there was a bias in favor of churches growing where administration and leadership/vision were recognized as the prime gifts. Regarding theological position the survey showed strongly in favor of growing churches having ministers who are conservative evangelicals with some charismatic dimension.

Regarding delegation of responsibilities in pastoral care, a clear tendency towards growth was present where elders and deacons had specific pastoral care functions, but the greatest bias towards growth was where there was a specific pastoral care team.

Considering Sunday services, frequent participation by lay people, regular guest services, regular appeals after baptisms and weekly outreach services showed bias toward growth.

2. The mobilization of the laity. Apart from what appeared above concerning participation in pastoral care and church services, lay participation in small Bible study and prayer cell groups supported growth. Visiting newcomers was more effectively done by lay people than ministers. Further, the greater involvement of lay people in these areas, the 
greater the growth. The conclusion of the survey was that a committed laity is a vital factor in church growth, both influencing the numbers reached and the quality of lives of the members themselves.

3. Church size. In the British context the size of the congregation did not seem to affect the growth possibility of the churches.

4. Structural balance. According to Wagner the optimal size of the congregational group is about 120 which was difficult to relate to the British situation as the total membership of the churches was predominately about that size. The survey indicated two things clearly: The use of music other than piano or organ in church services was clearly inclined to increase the growth of the church and the more that small group activity increased in the total program of the church the greater was the probability for growth.

In general the survey supported Wagner's fourth vital sign that these three types of activity should be present in the church and in a proper balance. Concerning the clear outcome of the survey regarding small groups the authors say:

"We have come to see that work in cells is the best means by which deeper fellowship with God and with others who love the Lord can become a living and vital reality. As this reality grows and develops, so it will permeate the whole lifestyle of the fellowship."1

5. The homogeneous unit. Regarding this principle the authors of the survey were not able to find anything to support it.

6. Effective evangelistic methods. Not surprisingly, the survey found that the more evangelistic activity in the churches, the greater their growth. Also churches which had

\footnotetext{
${ }^{1}$ Beasley-Murray and Wilkinson, 46.
} 
special committees responsible for outreach were more likely to grow. There was some support for evangelistic coffee bars, literature distribution and telephone ministries and there was a strong correlation between the employment of a full-time youth worker and the probability of church growth. Regarding direct evangelism a surprising result appeared for which the authors conjectured a reason: "When it came to actual evangelism, normal pastoral care appeared to be more effective than Sunday School, special missions, or even so-called evangelistic programs. ... It is likely that the on-going pastoral activities are reaping what has been sown though the other aspects of church life."1

7. Properly arranged priorities. Here Beasley-Murray and Wilkinson found that churches that placed spiritual nurture of the members as the highest priority were not more likely to grow than the average, but "the churches that listed outreach as their first and second priority had a strong bias toward growth."2 At the same time the churches that had community service as their main priority had a "definite bias towards non-growth."

The survey thus supported broadly five of the seven of Wagner's Vital Signs in the English context where the definite high points, that in the strongest way influenced the growth of the churches, were lay participation in ministry and the small group work.

\section{Statistical Analysis of Church Growth Principles- C. Kirk Hadaway}

C. Kirk Hadaway, in his book Church Growth Principles: Separating Facts from

Fiction, attempts to answer the questions, What factors are associated with growth, and what

$$
\begin{aligned}
& { }^{1} \text { Ibid., } 50 . \\
& { }^{2} \text { Ibid., } 51 . \\
& { }^{3} \text { Ibid. }
\end{aligned}
$$


factors are associated with decline? And also, What growth-producing factors are of greatest importance? The purpose of the book is then to answer these questions "with the best objective, scientific research available." It is fruitful to summarize Hadaway's findings in the light of the Beasley-Murray and Wilkinson results.

The following concerns are dealt with by Hadaway: (1) Outreach and Evangelism; (2) Sunday School and Small Groups; (3) Worship and Church Growth; (4) The Pastor's Role and Church Growth; (5) The Role of the Laity and Church Growth; (6) Setting Goals and Making Plans; (7) Attracting Visitors; (8) Assimilating, Retaining and Reclaiming Members; (9) Innovation and Distinctiveness; (10) Spirituality and Ministry; (11) The Community Context.

In his last chapter, "The Primary Principles," Hadaway then summarizes his findings, listing them as factors of critical importance, factors that have substantial effect but are not essential to growth, and finally, factors that can be seen as supportive of growth and thus go along with the primary principles.

The factors of critical importance were evangelism and outreach and the age structure of the churches, commitment and interest, and the right type of pastor for the church.

\section{Evangelism and Outreach}

The research showed that a very strong relationship exists between evangelism and

\footnotetext{
${ }^{1}$ Hadaway, Church Growth Principles, 12. Hadaway's major sources of data are a survey among five hundred rapidly growing, plateaued and declining Southern Baptist churches in 1988; a survey among plateaued Southern Baptist churches in 1988 where characteristics of churches having grown off the plateau were compared with those which remained on statistical plateau in order to test various theories and hypothesis for how stagnant churches can reverse longstanding trends and begin to grow; an older study of United Presbyterian Church in 1975 as a part of a larger effort to understand membership losses, and a study of United Church of Christ congregations at a similar time. In addition to these large-scale studies, information was also drawn from more limited studies.
} 
outreach and church growth and that "evangelistic outreach and recruitment are the primary methods through which plateaued churches achieve breakout growth and are the primary ways that growing churches continue to grow."

But the "evangelistic orientation of a congregation does not only refer to programmed forms of evangelistic outreach" but instead, "it is an open orientation to the outside world which says 'we are interested in your needs, we want for you to know Christ as we have come to know Him, and we would like for you to join with us in our struggle to learn, grow, and serve'."2 Thus such churches radiate the feeling that "witnessing about one's faith is normal and that it can occur anywhere, that the church has something to offer and members want to tell others about it."

\section{The Age Structure of the Congregation}

This second primary factor has an impact almost as strong as that of evangelism. Hadaway's research shows that "growing churches have a healthy mix of ages among their memberships and tend to incorporate a large proportion of baby boomer families and young single adult." ${ }^{, 4} \mathrm{He}$ takes an example of a congregation that is dominated by elderly people which is shown to be much less likely to grow than churches not dominated by one age group. Such a congregation will be less likely to meet the needs of potential members who are younger than the current membership, there will be a lack of programs for younger

\footnotetext{
'Ibid., 193.

${ }^{2}$ Ibid., 193.

${ }^{3}$ Ibid.
} principle.

${ }^{4}$ Ibid. But Hadaway points out that this could be seen more as a health characteristic than a growth 
adults, few if any resources for children, no youth program, much less ministry for single adults. Such a group is also likely to have many long-term members who have a tendency to be less open to changes in the structure and to be less accepting of newcomers.

\section{Commitment and Interest}

A third evidently essential factor to church growth is a high level of commitment to and interest in the church expressed by a large proportion of the regularly attending membership. Hadaway analyzes what factors reflect commitment and interest within a church and finds them complex. "Typically, it is a combination of great meaning and great spirit found in the church." What then can boost the commitment and interest? "Generally it takes more than a "wonderful" worship service... Warm fellowship, concern for one another, opportunities for meaningful service, and a seriousness about learning all contribute to the sense that the church is a good place to be.... Something tangible must be there which members not only receive, but that they create themselves."

In this context Hadaway deals with the role and function of the pastor in relation to growth. His research shows that preaching ability is virtually unrelated to growth and a pastor who is mainly a caretaker-nurturer is unlikely to emphasize what churches need in order to grow. Thus he finds that most objective measures of pastoral performance and competency are unrelated to church growth. What sort of a pastor should a church that is interested in growth then call? The model pastor is a "catalytic leader," "a man with a vision, and who understands how to work with and lead people in a loving and encouraging way. This sort of pastor is interested in developing people and in allowing them and

${ }^{1}$ Ibid., 196. 
empowering them to use their gifts." Further, the catalytic ideal leader does not allow his or her church to drift aimlessly and has a great interest in evangelism.

\section{Other Factors Having Substantial Effect on Growth}

1. Attitude towards visitors. Growing churches are more likely to provide special parking and seating for visitors. Visitors are recognized in worship services in ways that makes them feel wanted, but not embarrassed.

2. Intentionality of church towards growth. Some special programs during the church service should be put in place and some organizational procedures established which encourage church growth. Participation in such a plan implies intentionality on the part of a church which is acting on its identity as an evangelical congregation trying to reach people for Christ.

3. Additional paid staff. There are limits to the amount of growth a church can sustain without adding staff. Churches that want to keep growing will not look at added staff as a luxury but rather recognize it a proven way to ensure continued growth, the lack of which may eventually lead to plateau or pastoral burnout.

\section{Supportive Factors to the Primary Principles and Contextual Factors}

Growing churches tend to have, first, strong, effective Sunday school programs supply essential teaching, fellowship and assimilation for all age groups, which are also geared for outreach. Second, growing churches tend to have quality worship, a necessary, but not sufficient, condition for growth, as evangelistic churches with highly committed

\footnotetext{
'Ibid., 197.
} 
members who are reaching their communities for Christ tend to have exciting worship services.

Other critical supportive factors to church growth are, in order of importance, planning and goal setting, lay leadership, willingness to change, new member assimilation, and emphasis on prayer and spirituality.

Contextual factors mentioned by Hadaway as having substantial impact on church growth are the demographic setting, new housing and racial transition, economic status, the effect of proximity of churches of the same denomination. Finally, younger churches tend to be more likely to grow than older congregations. ${ }^{1}$

With regard to the contextual factors Hadaway concludes that churches "must understand their context, their competition, and their character."2 But although these factors are of importance for church growth and should be considered in planning for change they should not be viewed as deterministic however: "Unchangeable factors can be exploited, overcome, or used to shape the development of a more realistic identity. The church which does any of these things, but especially the latter, will be stronger and more likely to succeed than the church which uses a tried and true formula for growth which supposedly is applicable to any church setting". ${ }^{3}$

\section{Cell Groups and Church Growth-The Class Meeting in Early Methodism}

In a recent report in his research project among one thousand churches on a world-

\footnotetext{
${ }^{\text {'} I b i d .,} 202$.

${ }^{2}$ Ibid.

${ }^{3}$ Ibid., 202, 203.
} 
wide basis, which attempted to determine factors contributing to church health and growth, Christian S. Schwarz stated: "If we were to identify any one principle [promoting church health and growth] as the 'most important' ... without doubt it would be the multiplication of small groups." In the light of this and the general importance that has been placed in small group ministry recently in the cultivation of church life, it is of interest to the contemporary student of church growth to contemplate the very successful cell group ministry in early Methodism. In this study I seek to present an understanding of the role of the Methodist class meeting in the formation of the Methodist church in England and America, its role in the discipling process of the members, the engagement of the laity and the evangelistic outreach of the church.

\section{Origins and Significance of the Class Meeting}

Methodism, transplanted from Europe, started to form roots in American soil about the time of the birth of the United States of America. The movement soon experienced phenomenal growth, and by the third decade of the nineteenth century it was the largest denomination in America. In a remarkable way this new movement showed staying power and tenacity in withstanding opposition and difficulties in a new and harsh environment. It thus proved it was not a fleeting phenomenon soon to pass away but a movement that would become a decisive factor in the formation of the new nation.

The emphasis on cell group ministry was a unique feature in Methodism, in fact a hierarchy of groups was operated within its ranks of which the class meeting was the most

\footnotetext{
${ }^{1}$ Schwarz, Natural Church Development, 33.
} 
prominent and to which membership was required of all society members. ${ }^{1}$

\section{Background to the Rise of the Class Meeting in Methodism}

John Wesley's personal experience

The theological and structural developments of the Methodist movement under the leadership of John Wesley, including the formation of the class meeting, may be seen as having been influenced by his own theological pilgrimage and spiritual experience preceding the rise of Methodism.

Wesley himself began early in his life to search for spiritual assurance. His exercises in rigorous holiness and quest for perfection during his stay at Oxford are well known. His missionary journey to Georgia may also be seen as an abortive seeking of fulfillment. But his acquaintance with the Moravian Brethren on his way to Georgia and his subsequent interaction with them constituted a turning point in his life. The emphasis of the Moravians on experiential religion and sanctified life through close interpersonal encounter appealed very strongly to Wesley. "The communal piety of the Moravians was a great influence [on Wesley]. In them he saw the qahal, the Hebrew term for people called out for a special purpose, and the ecclesia, the similar Greek term which generally is translated as church. More specifically, these societies were what German pietism referred to as the "ecclesiola in ecclesia," the little church in the big church."2

The Moravian influence led Wesley to his own experience of "inward witness" in his

\footnotetext{
${ }^{1}$ David Lowes Watson, The Early Methodist Class Meeting: Its Origin and Significance, rev. ed. (Nashville, TN: Discipleship Resources, 1987), 118-20.

${ }^{2}$ Charles Robert Bruce, "Testing a Modified Wesleyan Model of Class Meetings in a Modern Setting as a Means of Integrating Lay Activity and Participation" (Ph.D. dissertation, Drew University, 1985), 11.
} 
famous Aldersgate experience in 1738 which was in fact a consummation of his prolonged conscious search. "This revelation of 'Christ in our hearts,' this 'divine evidence or conviction of his love,' had been an integral part of Wesley's earlier Oxford theology. His 1733 sermon, 'The Circumcision of the Heart,' made clear that his quest for personal holiness at that time was a searching for the same "distinguishing mark of the true follower of Christ ... renewed after the image of Him that created it."'

This striving found in Wesley while still in Oxford indicates in fact a rich heritage of the English Puritanism of the seventeenth century. "The true agenda of Puritanism was ... an experiential yearning for assurance, and in this the central doctrine was the indwelling Spirit. It was a doctrine well served by covenant theology, which stressed an experience of forgiveness and faith as a prerequisite for a covenant relationship, and which stipulated communion with God as a means of sustaining it."

Wesley's acquaintance with the Puritan literature is well established, ${ }^{3}$ and also his possibility of personal exposure through his remarkable mother, Susannah, and his father-inlaw, "a famous Presbyterian divine, Dr. Samuel Annesly of London.".4

The doctrine of distinct justification

Through his own personal experience and reflection Wesley arrived at an understanding of the distinctive doctrine of justification. In Oxford his quest had been for

\footnotetext{
'Watson, 47.

${ }^{2}$ Ibid., 24 .

${ }^{3}$ Ibid., 36 .

${ }^{4}$ Horton Davies, Worship and Theology in England, vol. 3, 2d ed. From Watts and Wesley to Martineau, 1690-1900 (Grand Rapids: Eerdmans, 1996), 186-187.
} 
holiness through "right intentions and earnest endeavor." What was lacking was the dimension of grace. What Wesley found compelling in the Moravian encounter was the expectancy of divine initiative. But the question was not only about the objective doctrine of justification but also the inward regeneration and of the new birth. Wesley emphasized that justification was by faith alone and that good works could only follow it, not precede it. ${ }^{2}$ But with this gift, which is what God does for us, came the gift of regeneration, which is what God does in us, enabling us to partake of the process of sanctification, an outward holiness springing from inward holiness of heart. ${ }^{3}$

The distinction of the elements of this process, though being inseparable, "was the touchstone of [Wesley's] theology, and more than anything else provided the shape of early Methodist discipleship." ${ }^{\prime 4}$

Wesley saw the work of sanctifying grace as empowering the will for an accountable discipleship and thought the aim of the Christian to be to press on in the process until the relationship of justifying faith was no longer interrupted by the wayward will thus reaching the mark of the mature Christian, a state of perfection-or as it appears in Methodist terminology, the "second blessing."

Here we have reached an important point for this study of Methodist discipleship as this distinctive doctrine of justification sheds important light on this question which is the main focus of study. This is well described by Watson and merits the following citation:

\footnotetext{
${ }^{1}$ Watson, 44.

${ }^{2}$ Ibid., 53 .

${ }^{3}$ Ibid.

${ }^{4}$ Ibid., 52.
} 
By restricting justification to a moment-by-moment sense of pardon, experienced by faith, Wesley infused a divine immediacy into the whole of Christian life. As he took the gospel the length and breadth of the land, he saw a wide outpouring of grace. $\mathrm{He}$ found, in richness of Methodist religious experience, a spiritual growth that was analogous to birth, childhood, and coming of age. He saw people brought to the critical point of surrender, their lives changed by justifying grace received through faith. When this was maintained in loving obedience, he saw the development of religious maturity - a Christian perfection which he came to regard as the "second blessing." When this second blessing was taken for granted, however, there was a falling away—even by the most mature. Obedience could not for a moment be neglected.'

Wesley saw thus a matter of highest expediency for Christian discipleship to provide conditions that would permit the constant flow of God's grace and thus foster maturity of constant obedience so that sanctifying grace might have unimpeded access to God's people.

It was Wesley's theological understanding of this question which led him to adopt what seemed an unbelievably simple solution: a weekly meeting of like-minded persons who would exercise a mutual accountability for their discipleship. This "prudential means of grace" was as profound as it was simple... The dynamic of the early Methodist discipleship was established at the very beginning of the movement on the solid theological principle of distinctive justification-how not to resist the immediacy of God's gracious initiatives. It remains the most important contribution made by Wesley, and by Methodism, to the Christian tradition. ${ }^{2}$

\section{The Rise of the Class Meeting}

Although we have seen the theological and practical bedrock upon which a system of small group could be erected in Wesley's movement, and seen ample precedent to it in Puritan, Anglican and Moravian tradition, this organizational structure seems to have come up entirely by chance within Methodism. Wesley was engaged in resolving a building debt in the first chapel building in Bristol in 1742 when the idea emerged from one of the members that each one pay a penny a week and if some where not able to meet that

\footnotetext{
I'Ibid., 64.

2Ibid., 65.
} 
requirement that membership be broken into groups of twelve with leaders over them who could contribute a penny for each of the eleven under his care who could not contribute. Each leader would make rounds of his class every week.

Very soon the class-leaders came to notice irregularities and moral problems among their class members which they discussed between themselves and with Wesley. Wesley immediately saw the validity of what was emerging: “"This is the very thing we have wanted so long.' I called together all the Leaders of the Classes ... and desired that each would make a particular inquiry into the behavior of those whom he saw weekly. They did so. Many disorderly walkers were detected. Some turned from the evil of their ways. Some were put away from us. Many saw it with fear, and rejoiced unto God with reverence. ${ }^{1}$

Only a year after this beginning in Bristol, the London society was organized at the Foundry with sixty-six leaders. ${ }^{2}$ Elsewhere this became a pattern that wherever Methodists commenced work, classes would be started at once by itinerant workers as the unit responsible for providing immediate care and spiritual nurture to the forming society: "Both in England and in America the Society, (and sometimes the Class before the Society) was the cell which the itinerant evangelist planted in the community where he preached." ${ }^{3}$

This method showed itself capable of adapting to the most diverse of circumstances. It also provided necessary stability as a building block in the progress of the work. "The stability and reproductive power of the Class and the Society accounted for the swiftness of

\footnotetext{
'Rupert Davies, ed., The Works of John Wesley, vol. 9 (Nashville: Abingdon Press, 1989), 254.

${ }^{2}$ C. R. Bruce, 13 .

${ }^{3}$ Ibid.
} 
the spread of the Methodist Movement and its success in thrusting roots into new soil."1

\section{Form and Dynamics of the Class Meeting}

Class meetings were held once a week and membership was required of all who would belong to the society. "Just as the class meeting was the occasion of membership, it was also the condition. As the "sinew" of Methodism the formation of the first class was the immediate priority when a new society was established... . The general, though unwritten rule was that three consecutive absences constituted self-expulsion from the class. ${ }^{2}$

Membership in classes was often required for some time before full membership in society was granted and new members were admitted to the class on a trial basis only. Permanent membership was established as a contract of devotion, and loyalty to the rules and objectives of the class and society was agreed on. ${ }^{3}$

Three basic rules governed the work of the classes, what we today would call their "mission statement": First, members committed themselves to "do no harm " and to avoid "evil in every kind." Second, they were to do good "of every possible sort and as far as possible to all men." Third, they were to attend upon "all the ordinances of God: Such as the publick worship of God; the Ministry of the Word, either read or expounded; The Supper of the Lord; Private Prayer; Searching of the Scriptures, and Fasting or Abstinence."

The proceedings of the meetings emphasized personal expression and the exercise of

\footnotetext{
${ }^{1}$ Ibid., 14.

${ }^{2}$ Watson, 107.

${ }^{3}$ Ibid., 106.

${ }^{4}$ Ibid., 108.
} 
mutual accountability: "The process was one of question and answer with the leader articulating what was felt to be the point which would most profitably be shared with the other members-a method which served to emphasize that the initial purpose of the meeting was for each person to give an account to the others of his or her discipleship."1

Wesley himself said the following about the proceedings:

[In the class] advice or reprove was given as need required, quarrels made up, [and] misunderstandings removed." Sometimes examinations revealed carelessness or even open sin. In these cases, Wesley tells us: "Evil men were detected, and reproved. They were born with for a season. If they forsook their sin, we received them gladly; if they obstinately persisted therein, it was openly declared that they were not of us. The rest mourned and prayed for them, and yet rejoiced, that as far as in us lay, the scandal was rolled away from the society. ${ }^{2}$

Finally, the role of the class leaders was one of utmost significance. Their position has variously been described as "sub-pastors," "non-commissioned officers," and even "spiritual police," but there is little question that they "became as skilled a group of spiritual mentors as the church has ever produced."

High standard was required of these lay-leaders. Their own lives had to be exemplary and they had to possess some obvious people skills in order to carry out their delicate function. Even though criticism sometimes arose, especially in later years, concerning unqualified and ill-educated class leaders, generally care was taken to choose worthy individuals to this key task. It was recommended that "the [class leader] should aim to make himself a master of theology, well acquainted with the sacred Scriptures, having lucid views

$$
{ }^{1} \text { Ibid., } 115 .
$$

${ }^{2}$ Charles Edward White, “John Wesley's Use of Discipline," Methodist History 29 (January 1991): 116 .

\footnotetext{
${ }^{3}$ Watson, 101.
} 
of doctrinal truth, of Christian experience, and of moral and religious duties. In order to teach, he must learn; to attain this he should study well the Bible and such works of human authority as throw light upon the work of grace in man's heart." ${ }^{1}$ Further, the class leader should discipline him or herself to be a spiritual assessor of people in order to be of help in their spiritual formation.

The leader should if at all possible see his members once a week, and if, due to any problems or neglect, the member was absent, he should without delay visit this person. Every week the leader should fill in the class book indicating the spiritual condition of his members, thus also allowing the local or itinerant preacher to make an evaluation at his visits. The class leader should promote growth and urge the members to unite with him in efforts to increase the class. Finally, he should make it a point of conscience to attend the class leaders meeting weekly, a meeting where all the class leaders would meet with the local preacher and give a report of their work.

\section{The Significance of the Class Meeting}

When examining this institution, the class meeting, one cannot but admire its efficient potentiality within the local societies. Within the context of the class meeting effective pastoral care and spiritual nurture was provided causing internal as well as external growth:

The class meeting was an institutional expression of Wesley's assumptions concerning pastoral care and general Christian duty. Convinced he would be required to give personal account to Christ for those who looked to him for personal, pastoral guidance, Wesley devised a system that emphasized supervision and the shaping of behavior as well as provision for general spiritual, emotional and physical needs "that it

\footnotetext{
${ }^{1}$ Ibid., 102-103.
} 
may the more easily be discerned, whether they [the members] are indeed working out their own salvation."

In our assessment of this institution today we might tend to place too much emphasis on the fellowship function of the meetings. Watson even goes to the extent to say: "It is a serious, though common error to assume that they were primarily intended for fellowship. Nothing could be further from the truth." ${ }^{2}$ He urges that the essence and the purpose of the meetings is to be found in Wesley's insisting on "holy people or no people" and the primary task of mutual accountability. Their task was to watch over each other in love; advising, exhorting, admonishing, and praying with the brother and sister. This and this alone is Christian fellowship. “The genius of Wesley's organization of the Methodist societies lay in his recognition that Christian discipleship was first and foremost a response to God's grace, and not a striving for virtue, nor yet an expectation of instant salvation."3 Finally, in the layled class meeting was found an effective way of recruiting lay leadership to positions in the societies which was of no small consequence to the future of the work. As we will see later, most notable leaders within the connection started their career as class leader.

The Effects of the Class Meeting in Methodism

\section{The Testimony of George Whitefield}

The mission endeavor of the Wesley brothers in Georgia did not, as is well known, bring success. George Whitefield, a fellow Methodist and successor of theirs in Georgia and

\footnotetext{
${ }^{1}$ David Francis Holsclaw, "The Demise of Discipline and Church Fellowship in Nineteenth Century America" (Ph.D. dissertation, University of California, Davis, 1979), vi.

${ }^{2}$ Watson, 116.

${ }^{3}$ Ibid., 87.
} 
close companion from the days of the Holy Club in Oxford, enjoyed much more immediate success during his many years of labor in America.

Whitefield extended his preaching beyond the South and itinerated extensively throughout the Atlantic seaboard. "He journeyed incessantly through the colonies, passing and repassing from Georgia to Maine like a "flame of fire."' Such was his fame and the effect of his preaching that "when he passed through ... his coming meant the end of all other business."

In this way Whitefield "quickened [the] continent,"3 but he was not instrumental in creating a lasting movement as he placed little or no emphasis on joining his converts in societies and classes as his colleagues in England did. "Had Mr. Whitefield acted in concert with Mr. Wesley; had the one ... established the discipline in America, which the other did in Europe; how different would have been the result." As is clear from his famous statement, Whitefield recognized the shortcomings of his work: "My brother Wesley acted wisely .... The souls that were awakened under his ministry he joined in societies and thus preserved the fruit of his labor. This I neglected, and my people are ropes of sand." ${ }^{1}$ Abel Stevens, A Compendious History of American Methodism (New York, NY: Eaton and
Mains, 1868), 31.

${ }^{2}$ Halford E. Luccock, Paul Hutchinson, and Robert W Goodloe, The Story of Methodism (New York, NY: Abingdon Press, 1949), 135.

${ }^{3}$ Stuart C. Henry, "The Colonial Period: 1736-1784-85," in The History of American Methodism, ed. E. S. Bucke (New York, NY: Abingson Press, 1964), 1:72.

${ }^{4}$ Richard Reece, "A Eighth Letter from Rev. Richard Reece on the Subject of His Late Visit to America," Wesleyan-Methodist Magazine, December 1825, 841, quoted in Henry, 1:72.

${ }^{5}$ Luccock, Hutchinson, and Goodloe, 134. 


\section{The Class Meeting and the Christian Witness on the Frontier}

We have noted Whitefield's lack of success in his preaching endeavors in America. But on his heels came the Wesleyan Methodist itinerants and a new era of Methodist work in America.

The inception coincided roughly with the achievement of American independence and the formation of the United States. This meant a new outlook and a fresh emphasis for the American people. Up to this time the established churches had concentrated on support for the quest for independence. This goal achieved, they found themselves stagnant and having little so say to a nation turning its sights toward new horizons and new challenges. The adaptability and mobility of the Methodist methods of outreach and nurture, especially its highly organized itinerant program and the class meeting, were features eminently suited for these new challenges.

The class meeting, which had proved so useful in England for new converts who had found themselves "standing in sharp contrast to their environment," was now the answer both in the established towns and cities and at the growing edge of America. In the sparsely populated areas an itinerant would find a few people who wished to become members, and he would form a class. At his departure he would not have to leave the believers on their own, so to speak. They had the means of remaining steadfast, combined in a unit where they could regularly support each others' faith and grow in grace. "In strictness, regularity, continuity, and cohesion, the class meeting was unlike any arrangement made by any other

\footnotetext{
${ }^{1}$ Richard R. Borholm, "The Evangelizing Community and Social Transformation," Foundations 20 (January-March 1977): 354.
} 
denomination in the frontier. It bottled and preserved zeal that, considering the emotionalism of the preachers, might otherwise have been scattered to the winds or dumped into the rivers." This institution also offered regular opportunities for neighborliness in an economy which welcomed such occasions. It offered the lonely and distraught a refuge, promoted close fellowship, and helped develop community in public life.

Itinerants met with the classes as they visited their circuit in order to get acquainted with their members and to promote a unified standard throughout their circuit. But the class leader, a lay person who met with the class weekly, carried the main resposibility for the spiritual formation of the group.

The class meeting prompted that religion be taken seriously where brothers and sisters in the faith took part in each other's successes and failures and exercised mutual spiritual accountability for each other. Here was "demonstrated the Methodist conviction that serious Christianity cannot be produced in a casual way, but only by discipline, good organization and purposeful witness." ${ }^{2}$ This institution kept Methodism, in spite of all the statistics of growth it piled up in its formative years, from becoming a mass movement. "Rather, it was a movement sustained at the community level by groups of small constituent bodies which helped to relate the individuals to the mass."

\section{The Class Meeting and Christian Discipline}

Wesley wrote: "The soul and body make a man, the Spirit and Discipline make a

'Luccock, Hutchinson, and Goodloe, 70.

${ }^{2}$ E. R Wickham, Church and People in an Industrial City (London: Lutterworth Press, 1957), 270.

${ }^{3}$ Charles Ferguson, Organizing to Beat the Devil: The Methodists and the Making of America (Garden City, NY: Doubleday, 1971), 74. 
Christian." He himself made no effort to accommodate his societies with those whose theology did not meet his criteria.

Numbers of converts were never a goal in itself in early Methodism. The leadership never flinched from expelling members. Wesley trimmed sixty-four members for different reasons from his society in Newcastle in March of 1743 and likewise cut the Gatehead society in half: from eight hundred to about four hundred! ${ }^{2}$ He was firmly of the opinion that where there was no church discipline, there would be no real Christianity.

The class meeting was the primary locus for discipleship and formation of the Methodist members. "Through [the] weekly meetings, the class leader would keep track of how the people were doing spiritually. Victorious members were encouraged, defeated members were helped, and stubborn members were disciplined. ${ }^{3}$

Bruce underlines that "the primary function of the class meeting ... was to teach new Christians and beginner Methodists the proper mode of conduct and the behavior expected of a Christian. ... Its greatest contribution was to disciple adherents to the sociotheological concept of the parent organization, the Methodist movement."4

Seeing how effective this practice was convinced Wesley that the work of God could not prosper without discipline. "With church discipline, however, early Methodism prospered, reaching almost a million before Wesley's death."

${ }^{1}$ Jon Telford, ed., The Letters of Rev. John Wesley, A.M., vol. 6, A Letter to William Church, October 13, 1778 (London: Epworth Press, 1931), 324.

${ }^{2}$ C. R. Bruce. 19, 20.

${ }^{3}$ C. E. White, “John Wesley's Use of Church Discipline," 122.

${ }^{4}$ C. R. Bruce, 16.

${ }^{5}$ C. E. White, “John Wesley's Use of Church Discipline," 122. 


\section{The Class Meeting and the Engagement of the Laity}

As we have already noticed, lay people held key positions in Wesley's movement. "Given the time and circumstances of his ministry and his personal heretage, it is absolutely remarkable that Wesley held such an uncommonly high view of the importance and capability of lay persons. In fact, almost against all his clerical instincts, Wesley seemed to recognize that it is the laity who are the church."1

By the middle of the nineteenth century there were probably about fifteen thousand lay members engaged by the Methodists in England in visitation and preaching and about twenty-five thousand class leaders ${ }^{2}$ and the extent of this lay initiative was in marked distinction to other denominations, and associated with an itinerant ministry it made Methodism, at base, a lay movement. ${ }^{3}$

What was the source of these numbers of able and articulate lay members among the Methodists? Wickham answers thus: "In fact the class-meeting became the strong groundfloor structure of the Methodist societies, accomplishing ends that were never envisaged not only religious and pastoral but also creating vital centers of responsible community life, often set in the midst of misery and debauchery. They produced active and articulate laity-at least great numbers of them-such as no other denomination has produced." ${ }^{4}$

What did Coke and Asbury, the great bishops of early Methodism in America have to say about the effectiveness of the class meeting: "Our classes form the pollars of our

\footnotetext{
${ }^{1}$ Borholm, 357.

${ }^{2}$ Wickham, 269.

${ }^{3}$ Ibid.

${ }^{4}$ Ibid., 268.
} 
work, and ... are in a considerable degree our universities for the ministry."

\section{The Class Meeting and Evangelistic Outreach}

Finally, we will consider the role of the class meeting in the evangelistic program of Methodism. John Wesley was, above everything else, an evangelist whose heart burned for the task of saving souls for Jesus Christ which is revealed by his astonishing life record: “John Wesley traveled by horse some 225,000 miles preached 40,000 sermons, and . . his achievements [were] perhaps 140,000 converts in his lifetime."

This near superhuman productiveness was not an isolated phenomenon in Wesley but rather a common character trait in the early Methodists, not the least among the American pioneers. And Wesley's philosophy of evangelism outlined here also characterized those of his followers during the great evangelistic thrust in late eighteenthand early nineteenth-century America.

Preaching was the accepted method of evangelism at the time. But Wesley recognized the validity of the small group as an additional tool. Hunter states, that Wesley "was driven to multiply "classes," for these served best as recruiting groups, as ports of entry for new people, and for involving awakened people with the gospel and its power."

Wesley's rationale for working in this way, according to Hunter, is rooted in his understanding of how people become Christians, upon which Wesley based his whole practice of evangelism. Awakening to lostness and need for God, which was accomplished

\footnotetext{
${ }^{1}$ Holsclaw, vi.
}

${ }^{2}$ George G. Hunter III, To Spread the Power: Church Growth in the Wesleyan Spirit (Nashville, TN: Abingdon Press, 1987), 40.

${ }^{3}$ Ibid., 56. 
by preaching, must necessarily be followed by class enrollment where people are taught to expect to experience their justification and, in turn, their sanctification in this life. ${ }^{1}$

Wesley observed that awakening people without folding them into redemptive cells does more harm than good. In a journal entry of 1743 he declared: "The devil himself desires nothing more than that the people should be half awakened and then left to fall asleep again. Therefore, I determine by the grace of God not to strike one stroke in any place where I cannot follow the blow." "

And a few years later he wrote: "I was more convinced than ever that the preaching like an apostle without joining together those that are awakened and training them up in the ways of God is only begetting children for the murderer."3

\section{Summary}

I have in my short survey sketched a picture of an emerging institutionalized cell movement in early Methodism, observing briefly its theological as well as its practical rationale, and also focused on its central performance in a movement that placed tremendous emphasis on evangelism and practical, disciplined Christianity.

It seems clear that the class meeting played a key role in the emerging Methodist movement serving as the building blocks as well as the cement within the societies. The class meeting played a key role in the life of the Methodist society with respect to pastoral nurture, discipline, and evangelistic outreach, and the opportunities this institution opened

${ }^{1}$ Ibid., 57.

${ }^{2}$ W. Reginald Ward and Richard P. Heilzenrater, eds., The Works of John Wesley, Journal and Diaries (Nashville, TN: Abingdon Press, 1990), 9:318.

${ }^{3}$ Ibid., $21: 424$. 
growing lay leadership, participation, and recruitment made it an inestimably important factor in making early Methodism the lay-operated movement it was.

\section{Church Growth in Contemporary Culture-Preaching Christ to the Postmodern Mind}

As a final section of this chapter I must include an analysis of the cultural shift that has taken place in the world and its ramifications with regard to the work of the church, especially its evangelistic outreach. I will focus on two main books: A Primer on Postmodernism by Stanley Grenz' where the author presents a general background for and outlines the essence of postmodernism, and Church Next: Quantum Changes in How We Do Ministry, by Eddie Gibbs, ${ }^{2}$ where Gibbs analyzes how this cultural shift challenges the Christian church and suggests possible ways in which it must respond.

There is a widespread claim among scholars that at present the world may be in the midst of a cultural transition equaling the changes that marked the birth of modernity out of the decay of the Middle Ages. The well-known authority within Christian circles, Stanley Grenz believes churches of today do not escape the effects of this transition: "Many churches today lie in the throes of an identity-crisis. The current malaise extends to mainline Protestant bodies, to hierarchical traditions such as the Roman Catholic Church, and to the worldwide coalition of theologically conservative and pietistically oriented groups we commonly call "evangelicals.". . . The current dissatisfaction within the church is, I

\footnotetext{
${ }^{1}$ Stanly Grenz, A Primer on Postmodernism (Grand Rapids: Eerdmans, 1996).

${ }^{2}$ Eddie Gibbs, Church Next: Quantum Changes in How We Do Ministry (Downers Grove, lL: InterVarsity Press, 2000).
} 
believe, part of a larger cultural shift transpiring around us."

Eddie Gibbs, a well-known church growth analyst, expresses it thus: "The transition from modernity to postmodernity represents a seismic shift that can result in churches becoming paralyzed in the midst of the shock waves. The changes are deep-rooted, comprehensive, complex, unpredictable and global in their ramifications."

The radical and pervasive changes taking place during this new era of "postmodernity" are being felt in most intellectual disciplines and society in general and are causing an erosion of the fundamental doctrines of modernity and the traditional way of perceiving reality. "Whatever it may eventually become, postmodernism has begun as a rejection of the modern mind-set launched under the conditions of modernity."

Many Christians, puzzled and disquieted by the mere term, eye postmodernism with much suspicion and retreat in disgust when confronted with the teachings of some of its most radical proponents. But established churches can no longer afford to ignore the advent of postmodernism and continue as nothing had happened, a development in fact considered by many as a liberation from under the oppression of the modernistic, anti-Christian outlook.

If the Christian church in general and the Adventist church in particular is charged with the task of communicating to the world the most vital messages of all times it must contemplate seriously the present change in the intellectual climate. It must engage in an analysis of the postmodern critique of modernity, draw some conclusions as to its effect on

\footnotetext{
28 (June 1992): 19.

${ }^{2}$ Gibbs, Church Next, 19.

${ }^{3}$ Grenz, A Primer on Potsmodernism, 162.
}

'Stanly Grenz, "The Community of God: A Vision of the Church on the Postmodern Age," Crux 
the Christian proclamation of the gospel, and pose the question in particular whether this new environment is to be viewed as a setback and a hindrance for the proclamation of the third angel's message or if the postmodern rejection of modernity opens a window of opportunity for the Seventh-day Adventist church's proclamation of its prophetic message and in what way this church can best accomplish its task in the postmodern environment at the very end of earth's history.

I will here raise a few questions that need to be addressed also by the Church in Iceland that takes its charge seriously in the present cultural climate and point out a possible course that may be adopted as a response.

\section{From Modernism to Postmodernism}

\section{The Modern Mind}

The modern era was born from the ashes of a war-torn Europe when the Enlightenment suggested hope in a hopeless world by turning peoples' eyes away from "all sorts of classical and medieval structures, social, ecclesiastical, and governmental,"' towards human reason and thought. "The bloodshed and chaos that followed upon seventeenth century differences of belief lent urgency to the quest for universal agreement. ... So from Descartes' time, the idea of human knowledge focused on the general, the universal, the timeless, the theoretical. . . Basing all knowledge on indubitable foundations would compel assent from all rational people."2

${ }^{1}$ Millard J. Erickson, The Word Became Flesh (Grand Rapids: Baker Books, 1991), 311.

${ }^{2}$ Nancey Murphy, Philosophical Resources for Postmodern Evangelical Theology (New York: Macmillan, 1990), 5-6, quoted in Mike Regele, Death of the Church (Grand Rapids: Zondervan, 1995), 62. 
The particular need that presented itself at this time was perceived to be a liberation of the human spirit from under the repressive institutions of religious and intellectual authoritarianism, that is the medieval church which had ruled the intellectual world for a thousand years. The church claimed its authority to be a divine endowment, transmitted supernaturally through divine revelation. It became the achievement of the Enlightenment thinkers, perhaps inadvertently at the time, to break this spell of the church. Authority, and especially the authority of revelation, was no longer accepted as the sure source of knowledge. "Truth had now to be justified at the individual bar of suspicion." In the words of Regele: "Human reason alone, through the careful observation of the sensible world, would establish one singular, universal story that would serve as the foundation of all reality, in a manner that was to be unassailable. The goal was to develop a "bombproof certainty" of knowledge."2

Neuhaus describes the seemingly contradictory consequence of the skepticism of the Enlightenment thinking of radical individualism and at the same time radical universalism. That is:

What can be known for sure (epistemology), and what ought to be done about it (ethics), can be discovered only by the autonomous and rational individual "unencumbered" by the particularities of his historical placement. This naked or unencumbered individual is, paradoxically, no recognizable individual in real life. Precisely because he is nobody in particular, however, the claim is made that his truth stands good for everybody in general; such truth is categorical and universal. That claim is at the heart of what the thinkers we have in mind mean by modernity. ${ }^{3}$

Characteristic for this new outlook which elevated humankind and the individual

\footnotetext{
'Murphy, 6.

${ }^{2}$ Regele, 62-63.

${ }^{3}$ Ibid., 1-2.
} 
self to the center of reality was Francis Bacon's (1561-1626) vison of humans exercising power over nature by the discovery of nature's secrets. René Descartes (1596-1650), laying the philosophical foundation for modernity, defined human nature as a thinking substance and the human person as an autonomous rational subject. Isaac Newton (16421727) provided the scientific framework for modernity, picturing the physical world as a machine the laws and regularity of which could be discerned by the human mind. The modern human can thus appropriately be characterized as Descartes's autonomous, rational substance encountering Newton's mechanistic world. ${ }^{1}$

As a consequence of this thinking the correspondence theory arose, ${ }^{2}$ enabling the mind to discern the structures inherent in the external world through reason. It became thus the quest of Enlightenment thinkers to discover the laws of nature in a self-contained universe. These beliefs led to the Enlightenment's declaration of autonomy and rejection of external authority. Censequently biblical authority and Christian dogma were increasingly put to the test of reason. Furthermore, Enlightenment thinkers maintained that the world was orderly, including humankind into the harmony of the cosmos, thereby downplaying the Christian emphasis on the depravity of man. This principle of harmony should also function as an ethical principle governing man's actions. Finally, the Enlightenment firmly believed in inevitable progress. In an orderly, knowable universe,

'Grenz, A Primer on Postmodernism, 2-3. "As the crowning act of the construction of modernism the problems encountered as a consequence of the Cartesian dictum of the thinking self, culminating in the skepticism of David Hume (1711-1776), were resolved by Emanuel Kant's (1724-1804) doctrine of 'the active mind' and the affirmation of 'transcendental categories' as the foundation of knowledge, which elevated the autonomous self to the center of the intellectual agenda," 85 .

${ }^{2}$ The correspondence theory assumes the correspondence between the structure of the human mind and the structure of the universe. 
proper methods would lead to true knowledge, the discovery and application of which would make humans happy, rational and free. Knowledge was thus inherently good.

\section{Rejection of Modernism}

Postmodernism embodies a rejection of the Enlightenment project and the foundational tenets on which it was built. Its demise did not come suddenly. During the nineteenth century German romantic philosophers were increasingly troubled by the "fiction" in the reigning Cartesian-Kantian epistemological legacy of an objective world existing in its own right beyond the self, which related to the concept of the autonomous thinking self existing transcendently over and above the person itself. Thinkers stumbled over the inevitable dualism within the human person of material and nonmaterial substances which became the consequences of this thinking.

The most devastating criticism of the modernistic philosophy was leveled by Friedrich Nietzsche (1844-1900) who heralded the complete demise of the Enlightenment epistemology thus paving the way for postmodernism. To him a universal, transcendent frame of reality does not exist, everything is a "perspective appearance" the origin of which lies within us. In the mind of Nietzche there is no reality behind or beyond this web of illusion. Neither are nature's "laws" anything but constructs, human impositions upon the world which in its individuality, creativity, and richness transcends our intellectual constructions. No two things are the same. Thus the inherent conceptualizing in the modernistic view robs reality of its multiplicity and destroys the variety of human reality, rather than mediating real knowledge.

This led Nietzsche to initiate a trend that developed into the so-called "aesthetic 
metacritique" of the understanding of truth viewing the work of art, texts, or language as providing the grounds for truth's own possibility. This is what postmoderns have developed and made a fundamental pillar in their program.

In tracing the development further through the nineteenth and twentieth centuries, one must mention the emergence of modern hermeneutics with Friedrich Schleiermacher (1768-1834), the "father of modern theology," who suggested that in order to understand a written work we must reconstruct the process by which it was created. Further along the lines of hermeneutics Wilhelm Dilthey (1833-1911) complicated the interpretive task by referring to the "hermeneutical circle," maintaining that the understanding of texts requires familiarity with its parts and its whole. But the whole cannot be discerned without a knowledge of the parts and the parts not without a grasp of the whole. This undercuts all hope of finding a self-evident, transcendent certainty of unconditioned knowledge.

Martin Heidegger (1889-1979) comes along and levels yet another attack at the Cartesian-Kantian concept of self which engages in cognitive act, attempting to rid it of the besetting dualistic notion of the subject as an independent substance, existing above time and human society. He claims that we are above all else beings-in-the-world, enmeshed in social networks, his famous Dasein concept.

Hans-Georg Gadamer (1900-2002) seeks the seeming impossibility of avoiding the two "heresies": objectivism of the Enlightenment and relativism of perspectivist thinkers claiming that meaning emerges as the interpreter engages in dialogue with the text of the world thus giving rise to a "fusion of horizons" between the interpreter and the world. 
Also Ludwig Wittgenstein (1889-1951) and Ferdinand de Saussure (1857-1913) come along with an attempt to reconstruct language in the wake of Nietzsche's attack on modernity, resulting in the assertion that language is a social construct.

After relentless attacks by one thinker after another, the modern worldview began to break down during the twentieth century. Regele points to three factors contributing to its demise: "Failure of epistemology to develop an unassailable (bombproof) certainty. Failure to develop a 'grand narrative,' the 'super story' that gives meaning to all other stories. The emergence of the global village, which brought ideas from other places and belief systems together at the time modern epistemology began to fail."

As we have seen Nietzsche had leveled some stinging criticism towards the grand quest of modernity to secure the certainty of knowledge. Early in the twentieth century most philosophers and scientists would agree that this quest had been a failure.

\section{Postmodern Philosophers}

As representational contemporary postmodern philosophers the following three should be mentioned:

Michel Foucault (1926-1984), a disciple of Nietzsche, rejected the Enlightenment concept of the self, the autonomous knowing subject, who views the world as an object accessible to human knowledge, and he holds that every interpretation of reality or assertion of knowledge is an assertion of power. Following Nietzsche he elevates the

\footnotetext{
${ }^{1}$ Ferdinand de Saussure, a Swiss linguist, is considered to be the founder of modern linguistics in its attempts to describe the structure of language rather than the history of particular languages and language forms (structuralism).

${ }^{2}$ Regele, 66.
} 
specific and special above the general.

Jacques Derrida (1930), philosopher and literary critic, is concerned with the nature of language and seeks to open up the "hermeneutical" possibilities of the written word in the engaging in an ongoing conversation with the text. Derrida claims that the self does not exist apart from its context and that "there is no self standing beneath or preceding linguistic activity." In his mind the experience of the singular, objective present is an illusion. Through language and concepts we impose the sense of objective meaning on the flux of experience. Through deconstruction Derrida assaults logocentricism, understood as the assumption that something lies beyond the system of linguistic signs to which a written work can refer to substantiate its claim to be an authentic statement.

Richard Rorty (1931), an American philosopher, presents postmodern pragmatism in the vein of John Dewey. He thus holds a nonrealist view of truth as being a matter of human convention therefore denying the correspondence theory of truth. He is also a nonessentialist, focusing on relational properties rather than on what things are "in themselves."

\section{Description of the Postmodern Worldview}

James Sire suggests five different fundamental values that make up the mind-set of postmodernism. These are:

1. Things and events do not have intrinsic meaning. There is only continuous interpretation of the world.

2. Continuous examination of the world requires a contextual examination; we

\footnotetext{
${ }^{1}$ Ibid., 144.
} 
ourselves are a part of the context.

3. Interpretation depends not on the external text or its author, but on the relative viewpoint and particular values of the interpreter.

4. Language is not neutral but relative and value-laden.

5. Language conveys ideology. ${ }^{1}$

\section{Deconstruction}

One of the main concepts of the postmodern worldview is deconstruction. Its roots lie in communication and literary criticism. In fact it arose as an extension of the theory in literature called "structuralism." Deconstructionalists do not believe that words have objective content. They hold that meaning is not inherent in a text itself, but emerges only as the interpreter enters into dialogue with the text. ${ }^{3}$ This means that the reader does not only extract meaning from the text, but in the course of reading actually must infuse his own experience and values into the text. Thus "reality is only that which we create in our minds through language. Knowledge is not so much found as it is made."4

It follows that words do not have objective meaning. Everything depends on not

\footnotetext{
'James Sire, "Logocentricism and Postmodern Apologetics," Calvin Theological Journal 26
} (1991): 412, quoted in Gary Zustiak, The Next Generation: Understanding and Meeting the Needs of Generation X (Joplin, MO: College Press Publishing Company, 1996), 132-133.

${ }^{2}$ Perhaps the best introduction to deconstruction in literature is a point Richard Rorty made in discussing epistemology. He tells of a cosmologist who held, as many ancients did, that the world rests upon the back of an elephant. When asked what the elephant stood on, he replied, "It's elephants all the way down." Reality, says Rorty, should now be understood in a similar fashion- "It's words all the way down." Richard Rorty, Consequences of Pragmatism: Essays 1972-1980 (Minneapolis: University of Minnesota Press, 1982), xxxv, quoted in Erickson, 308-309.

${ }^{3}$ Grenz, A Primer on Postmodernism, 6.

${ }^{4}$ Zustiak, 137. 
only who is speaking, but also who is listening and in what context they are spoken, heard, or read. ${ }^{1}$ An extension of this concept is that every interpretation of a text is equally valid and the readiness to accept even contradicting interpretations, seeing that there does not exist an external absolute point of reference. "This means there is no one meaning of the world, no transcendent center to reality as a whole, but only individual interpretations of it." What, according to the postmodern way of thinking, applies to the interpretations of texts must necessarily in their system also apply to all other fields of inquiry, including science, reason, and theology.

\section{From Modern to Postmodern Theology}

\section{Modern Theology}

Erickson summarizes the effects of modernity on theology. ${ }^{3}$ He refers to David Griffin's division of modern theology into early and late periods. The early period "was characterized by an attempt to accommodate theology to the modern worldview by reducing its content." ${ }^{\prime 4}$ This was probably most clearly represented by deism in the late eighteenth century. The fundamental aim was to form some sort of a universal religion out of all the positive qualities found to be common in the different religions. This project, however, proved to be a failure and late modern theology gave up the concept of

\footnotetext{
${ }^{\text {l }}$ "To interpret the meaning of a given text is to impose meaning on it. To say "This is what it means' is to misread it." Kevin Graham Ford, Jesus for a New Generation: Putting the Gospel in the Language of Xers (Downers Grove, IL: InterVarsity Press, 1995), 120.

${ }^{2}$ Zustiak, 137.

${ }^{3}$ Erickson, 305-306.

${ }^{4}$ lbid.
} 
universality and accepted pluralism. Erickson then points out two further adjustments made. In contrast to the public verifiability that science and science-based philosophy demanded, theology started to rely more on subjective truth and personal piety.

The several postmodern theologies that have emerged agree in their understanding of modernism, that this period is over, but that the modern world has produced some outstanding contributions which must not be lost sight of. So they seek to advance from where modern contributions end rather than to return to the premodern era.

\section{Types of Postmodern Theology}

Erickson identifies four basic types of postmodern theologies that have emerged.' Notwithstanding their agreement on the nature and inadequacies of modern theology they exhibit quite a diversity. First, constructive or revisionary postmodern theology seeks relevance in a rapidly changing Western culture which is accepting a postmodern worldview. Second, deconstructive or eliminative postmodern theology maintains that the objective approach of constructivism leads to the paradoxical conclusion that an objective approach is not possible. This eliminates all worldviews and leads to relativistic schemes. Third, liberationist postmodern theology emphasizes the need to transform society, and, fourth, restorationist or conservative postmodern theology, only appearing in Roman Catholicism, seeks to go beyond postmodernism while at the same time holding on to elements of premodern theology.

\footnotetext{
I'Ibid., 307-308.
} 


\section{Preaching Christ in a Postmodern Age}

\section{The Postmodern Generation}

The philosophical and scientific currents in Western society and their implications may not have been the object of study of the general public. Still the sentiments have thoroughly shaped the way of thought of the present generation. Ford comments: "The implications of these various influences have slowly filtered from the scientific community and the intelligentsia to the arts, the entertainment media and the news media. Over a period of sixty or more years these implications have gradually solidified into the present framework for the way our culture thinks and perceives reality."1

Ford claims that these sentiments have saturated the present generation's view of ethics, morality, philosophy, and religion to the extent that it no longer feels that an absolute, objective point of view in matters of morality or religion is defensible. Further, the present generation claims that subjective experience supercedes logic and objective facts, it claims a right to believe according to what feels comfortable, and does not want to be confused with the "facts" of the matter. Consequently, the present generation also views truth and the nature of God as relative concepts where every individual is free to formulate his own private version of the Supreme Being.

\section{The World of the Postmodern Generation}

What also characterizes the postmodern generation are unprecedented social and environmental problems of the post-industrial information age. "Modernity began to crumble and topple when it became increasingly evident that ... human progress bore 
within it the prospect of a self-destruction. There were unseen consequences that threatened to render the planet uninhabitable.... New technologies designed to free the human spirit and remove physical drudgery created new dependencies and enslavement."1

This generation has experienced the struggle for free abortion leading to the termination of millions of pregnancies each year occasioning the terms "Survivors" or "Baby Busters" for this generation. This is the generation that experienced a flood of mothers entering the job market, the age of the "latch kids," the age of unprecedented overt dysfunction of families, and soaring divorce rates, all contributing to the sense of child-unfriendliness of the age. It is the generation of unparalleled reported sexual abuse, drug and alcohol addiction, and disastrous decline in educational performance.

This environment has created a feeling of hopelessness and pessimism for the future and resulted in an avalanche of behavioral problems such as decreased respect for authority, steep rise in criminal activity among the increasingly young, and the ignoring of warnings about the danger of drug abuse and promiscuous sex. Finally, this is an age of stress, rising suicide levels, and mental problems.

\section{Window of Opportunity}

As has become abundantly clear in this discussion, postmodernism poses a formidable challenge to Christian evangelism. How can we then carry the story of ultimate truth to this generation that sees words as having no meaning, faith a matter of perspective and interpretation, and mission a flagrant expression of intolerance? In a world where there is no correspondence between words and absolutes the Ten

${ }^{1}$ Gibbs, Church Next, 23. 
Commandments become Ten Suggestions. To the deconstructionist mind Jesus' words in his High Priestly prayer in John 17:17, that the words of God-God's logos-are truth, are pathetically absurd. ${ }^{1}$ Obviously the generation thus described is not going to respond to new truth claims of Christianity.

But postmodernism may well be, if properly understood, an opportunity in disguise. It would be ironic if Christians were to brace themselves as modernism's last defenders, especially in view of the fact that the true nature of modernism is in fact hostile to the Christian worldview. ${ }^{2}$ The most conspicuous monument of the Enlightenment project of modernism is after all the "radical scientific belief system that has waged such a successful war against Christianity in the twentieth century. It is the modern rationalistic, materialistic, scientific mindset that claims nothing exists if it cannot be quantified and examined within a scientific framework."

On the contrary, in spite of its dismissal of absolute truth, the postmodern mindset allows for the existence of realities that science cannot measure - the supernatural, the transrational, the spiritual, the eternal, the ineffable, the numinous realities that are central to the biblical story. Consenting to such notions the postmodern worldview has provided an invaluable link of communication with the Christian gospel.

\section{The Healing Community}

In an age that rejects the modern paradigm with its focus on the self-reflective,

\footnotetext{
${ }^{1}$ Ford, 118.

${ }^{2}$ Grenz, A Primer on Postmodernism, 10.

${ }^{3}$ Zustiak, 123.
} 
self-determining, autonomous subject who stands outside any tradition or community, the communitarian emphasis carries a strong appeal. This is especially so for a generation which to an unrivaled degree lacks the fulfillment of the need for community, as family and society in general have failed them in this respect. As a response to this need the gospel must be presented in the context of a healing relationship and the church is, in fact, functioning according to the biblical ideal, the deepest and best form of community possible, reflecting the divine ideal so powerfully portrayed in the Sabbath institution. This is the communal reality that postmodern pre-Christian people hunger for.

This entails that the church as a locale and as a body of believers becomes the main avenue of evangelistic activity rather than a large impersonal, lecture-type meeting.

In order for the church to become such an environment it must manifest loving care as a prevailing, perceptible attitude, exhibited between church members, towards visitors, and towards the unbelieving community in which the church is located. Authentic expressions of love and care, springing from a true conversion experience, should become a conscious campaign within the faith community as well as a part of the outreach of the church under the principle that one exemplary loving relationship will stimulate another, creating a chain reaction and thus promote the growth of the church.

\section{Experiential Religion: The Interactive Method of Presenting the Gospel}

In spite of the post-rationalistic mind-set of postmodernism of the age, the Christian church "must continue to acknowledge the fundamental importance of rational discourse, but our understanding of the faith must not remain fixated on the propositionalist approach that views Christian truth as nothing more than correct doctrine 
or doctrinal truth." The heart of the Christian experience is a personal encounter with the living God in Christ that shapes us and molds us.

The double importance of the propositional statements of Christianity must remain in vogue as these both assist in initiating and making sense out of life by recounting the story of transformative experiences. They thus both facilitate and express the encounter with God in Christ, they serve the conversion experience, and arise out of the new status as a believer. ${ }^{2}$

But the propositional expressions must also be culturally sensitive and dynamic. In other words, in its entrusted administration of the gospel in the world the church must operate according to the incarnational principles of Christ's own ministry as he took on himself "the very nature of a servant, being made in human likeness" (Phil 2:17), and as exhibited in the ministry of Paul, who strove towards "becoming all things to all men" (1 Cor 9:22). According to this principle the early church, during the Jerusalem council (see Acts 15), sought to distill the distinctly Christian view of ultimate reality from outer culturally conditioned forms which are negotiable. The authentic presentation of the gospel thus calls for a constant search for a dynamic application of eternal truth in a changing world. The church can never be content with repeating the methods of presenting the everlasting gospel inherited from earlier generations but must itself mine it from the sources available.

As Adventists today we must constantly apply these sources, coupled with and immersed in the inspired counsel of Ellen G. White, and thus in an interactive way apply

'Grenz, A Primer on Postmodernism, 170.

${ }^{2}$ Ibid., 171. 
the body of truth available to us to the present under the indwelling influence of the Holy Spirit. In this way, in the words of Jon Dybdahl, we must "undertake the imperative task of creating and articulating a clear, positive vision of our mission."

\section{A Holistic Gospel}

To the postmodern mind that denies the mind-matter dualism of modernism the church must present true biblical holism as this generation is increasingly interested in the unified human being.

Christianity has long primarily been interested in the spiritual aspect of human beings. Only secondarily has it shown interest in the physical aspect as this had no eternal importance. The Adventist Church, although considering itself well prepared to minister to this need as it has always acceded to the biblical holistic view of the human being, must consider the full extent of this challenge.

While focusing on the physical, mental, and emotional aspect of human beings as well as the spiritual one ministered to by traditional Adventist health evangelism, holism is a wider concept dealing with the human being in its socioeconomic, political, and environmental context, areas frequently neglected by the Adventist church. The present thinking urges us as Christians to reexamine the Scriptural message and the counsels of Ellen G. White to discover the rich emphasis placed on concern for the present realities under which human beings live and our duty as the followers of Christ to show compassion and to seek relief for them from oppression in whatever form. Ministries such as alleviation of racial injustice and sexual discrimination, concern for the gay and lesbian 
population, one of the most severely persecuted minorities in our societies, and practical concern for the AIDS stricken, the hungry and the homeless, and concern for environmental issues must be on the agenda of the church.

The question in the postmodern arena is not so much: "Can Christians prove what they believe?" as "Can Christians practice what they believe?" As Grenz has put is: 'If you step into the pulpit and say, 'I'm going to give you five reasons to believe in God,' and the reasons you give are all intellectual, evidential and cosmological, you'll have little or no impact. The impact comes when you can say with authenticity, 'I've been knocked around by life, but through the pain of it all I've experienced that God is there.' That's an embodied apologetic, and that counts withThirteeners."

\section{The Gospel of Power}

Lastly, we must consider the special motivation that characterizes the postmodern generation. This is a generation of great need as we have seen. It is a generation in the paradoxical situation of being surrounded by, or even possessing, unparalleled wealth and witnesses unbelievable scientific advances, but still suffers from poverty in the form of insecurity, lack of affection, and by living under darkened horizons offering no hope for the future. This is a generation that it highly motivated to accept spiritual things. It is a generation with a survival mind-set that is seeking a faith that "works" in the real world. People need something that will make a practical difference in their everyday lives, and a faith that does not tangibly improve their life will very quickly be discarded. Here is generation that is motivated to be used by the Holy Spirit in a mighty way, ready, because

\footnotetext{
${ }^{1}$ Stanley Grenz, quoted in Ford, 174-175.
} 
of its sense of need and its openness to the spiritual dimension, to become a mighty instrument in the hands of God at this last hour of human history. May it be that God's hand is presently engaged in the raising of a receptive generation having access to unique and unequaled possibilities of communication and molded by the postmodern sentiment influencing both the Western world as well as the rapidly urbanizing two-thirds world?

\author{
The Church's Reaction to \\ the Challenge of Postmodernism'
}

The main purpose of Eddie Gibbs's book, Church Next: Quantum Change in How We Do Ministry, is to help church leaders come to realize the consequences of this as in the postmodern environment "the church finds itself pushed out to the wings of the social stage" and that "secular society only allows the church's representatives on stage on its own terms." Thus the church will ignore the present changes in cultural trends only at its own peril and the risk of "becoming paralyzed in the midst of the shock waves" and experience a great setback. Gibbs especially seeks to arouse church leaders to a realization of the fact that the recent successes of the so-called seeker-sensitive approach to church growth must not create a basis for future strategy and planning as this method is in fact merely "a media-hyped response to modernity," attracting mainly the baby boomer generation but not the postmodern Generation X:

In contemporary society, which is increasingly permeated by postmodern thinking, maintenance-minded churches need to be transformed into missional mindedness, which will entail decentralizing their operation. Church leaders will need to facilitate this transition by giving higher priority to working outside the institution, functioning as teams of believers located in a highly polarized and pluralistic world. From a

\footnotetext{
${ }^{1}$ A review of Eddie Gibbs, Church Next: Quantum Change in How We Do Ministry (Downers Grove, IL: InterVarsity Press, 2000).
} 
strategy of invitation to one of infiltration, to being the subversive and transforming presence of Jesus. ${ }^{1}$

In pointing out the changes in the thinking and the methodology that need to take place in the church Gibbs works with transitional topics in his book. I will shortly summarize the main points of his argument under the following headings: From Market Driven to Mission Oriented; From Following Celebrities to Encountering Saints; From Dead Orthodoxy to Nurturing Living Faith; From Attracting a Crowd to Seeking the Lost, and The Missiological Challenge.

\section{From Market Driven to Mission Oriented}

While Gibbs concedes that valuable lessons can be learned from marketing he points out some serious problems with making marketing and the filling of felt needs the basis of the program of a church or its evangelism.

1. The market-driven strategy distorts the Christians' view of unbelievers as weli as the process of telling others the gospel with the allure of success (the bottom line in marketing is numbers) as a church may be completely devoid of spiritual life and still be increasing in numbers and influence.

2. Further, marketing makes the audience sovereign and propagates the attitude that "the customer is always right." Such an attitude might provide an impressive boost to sales but is disastrous when applied outside of the realm of commerce. This eliminates the core element of the gospel, humility, and the breaking of a rebellious spirit. We must attract people as fellow sinners not as customers, confessing that we have only one answer

\footnotetext{
${ }^{1}$ Ibid., 218.
} 
to our common need, our risen savior, Jesus Christ.

3. Finally, this approach bases our message on meeting human needs. There is a serious danger then that the message will be distorted, edited and compromised in the interest of relevancy and immediacy. The entire gospel enterprise will thus be shaped by consumer needs which in fact creates an addictive situation.

The church must be engaged in mission and the missional orientation counters the marketing approach as mission means sending. Churches cannot stand apart from society and invite people to come to them on their terms. Rather, churches must go to people where they are and communicate in terms that will make sense to them, addressing the issues that shape their lives and speaking their language. The motivation for mission is the Great Commission and doxological motif of bringing glory to God's name. And if evangelism means that those who know Christ introduce him to those who do not, then those who are seeking to make him known must themselves reflect an intimate relationship with the Lord. Otherwise the introductions are likely to prove abortive.

\section{From Following Celebrities to Encountering Saints}

In Gibbs's mind the success of the church in the postmodern age will depend more on renewed spirituality than skills, more on authenticity as a follower of Christ than ability to develop charisma, communication genius and management acumen of pastors leading super churches. There will be a quest for authenticity as Gen Xers are not interested in listening to people who presume to have all the answers but will rather associate with those who have a transforming relationship with God. They are suspicious of bigness, of advertising and ego trips but want churches that are down-to-earth and unpretentious. Gen 
Xers respect God-inspired service to their fellow human beings and people who speak the truth whatever the personal cost. They respect honest people who are prepared to admit there are things they do not understand and own up to shortcomings. Gen Xers yearn for hope for the future which is not based on human abilities, and they are prepared to live with ambiguity and question marks. It is the prospect of an unfinished sentence marking the moment of oblivion that scares them.

\section{From Dead Orthodoxy to Nurturing Living Faith}

Gibbs then turns to appraise the so-called seeker-sensitive approach to church growth and evangelism in light of the present development. He recognizes this method as a serious attempt to engage the cultural setting in which the local church is endeavoring to bear witness and must not be lumped with the market-driven churches that tailor their message and employ any gimmick in order to attract a crowd. At its best, the seekersensitive approach attempts an incarnational presence in the community it seeks to reach in the name of Christ and must be commended when they operate with theological integrity, evangelistic passion and pastoral sensitivity: "In any attempt to reach those who are not yet Christians or who have become disillusioned with institutionalized Christianity, every obstacle erected by people needs to be removed. The only 'offense' that must remain is that of the cross of Christ, where all roads to the Father must eventually converge."'

But Gibbs reminds us of the need for discernment and accountability in the application of authentic incarnation and that it must lead to significant transformation in the lives of those who are converted due to the counter-cultural effect of the gospel: "What

\footnotetext{
${ }^{1}$ Ibid., 148.
} 
is true of God's dealings with his people throughout history also holds true for the way the gospel relates to culture. It is indeed "good news" in bad times. But this does not imply that it is a panacea, baptizing culture with a heaven-poured whitewash."1

While the gospel may affirm some elements in a culture and fulfill some unrealized cultural aspirations, it also addresses the demonic element present in every culture. Therefore, contextualization is from a critical, not a naive standpoint.

In critiquing the work of the seeker-sensitive churches Gibbs points out that

1. They have not been very successful in reaching their primary target, the unchurched ("never-churched"), but mainly attracted formerly churched boomers.

2. More seriously, much of their crowd are transferred members from smaller churches.

3. Further, there is growing evidence that a significant percentage of boomers who returned are now leaving in disillusionment.

4. Gibbs ascribes this to boredom that eventually sets in when worship degenerates into "spectatorism." The inherent problem is that the seeker-sensitive model requires a continuous flow of creativity in order to sustain the entertainment factor.

5. Here Gibbs sees a fundamental problem: "In true worship, God is the audience, not the congregation, and those who lead worship are not the center-stage performers but the off-stage prompters and facilitators."2 Then the whole enterprise may to some extent be misguided as "people are not looking so much for worship that is relevant as they are

\footnotetext{
${ }^{1}$ Ibid., 149.

${ }^{2}$ Ibid., 146.
} 
for worship that is real." And many people tire quickly of celebrity-based religion where one gifted person is the center of attraction. They go to a church where God is the center of the worship.

\section{From Attracting a Crowd to Seeking the Lost}

Turning now to the applicability of the seeker-sensitive method to the postmodern culture Gibbs sees this approach as proving to be an inadequate response to the most recent challenges confronting the church and concedes that 'the 'megachurch' concept, the 'seeker church,' and the new 'Cell' church, are but well thought out attempts to breath new life into old structures."”

Gibbs's argument is that what the unchurched, especially the Gen Xers, are in fact seeking is genuine worship as their quest is more spiritual than intellectual and thus it is a mistake to underestimate the significance of authentic worship for the seeker. Then the way forward is not simply a matter of developing better marketing strategies or presenting an updated image but rather "a transforming experience of God and a deeper engagement with Scripture, both in fashioning the internal life of the church and in defining its mission in the world. Churches will need to become genuinely apostolic congregations committed to living out their faith in the world."

Gibbs then evaluates the significance of worship in evangelism and underlines that we must constantly remind ourselves that the essential focus of worship is God himself. It

\footnotetext{
'Ibid., 155.

${ }^{2}$ Ibid., 172.

${ }^{3}$ Ibid., 178, 179.
} 
is not primarily entertainment or instruction, a morale booster or an exercise in selfrealization and it must not be subverted to serve other ends as "our highest calling here on earth is to give glory to God in the praise offering of our lips and of our dedicated lives."1 In its witness the church must enter into genuine worship as "it is difficult to witness convincingly about a God we do not know and love in our inmost being," and when it comes to worship, seekers are not interested in "watching us go through the motions."

The seeker-sensitive program does not engage seekers in worship on the premise that this would be meaningless to nonbelievers. They are thus just passively present as observers. Here there needs to be a shift from anonymous observer to relational participant especially as this also represents a change in learning styles between many boomers and Gen Xers. And the worship needs to contain all the essential elements: (1) Reconciliation with God and with one another, (2) inspiration through the awareness of God with us in word, sacrament and saving signs, and (3) transformation that results from the encounter with the Divine. Lifeless, meaningless worship will inevitably put off the newcomer who is not yet a believer.

Gibbs observes that much contemporary worship is lacking in content. Morgenthaler says it "fails not only to appeal to seekers in our midst, but it also fails to be a transforming experience for many church members. More and more of us are leaving our worship centers and sanctuaries without even so much as a mar on our glossy finish! We are going out the same way we came in. We may have had an entertainment fix, a self-

\footnotetext{
${ }^{1}$ Ibid., 179, 180.

${ }^{2}$ Ibid., 180.
} 
esteem fix, a self-righteousness fix or a self-help fix, but we have not been changed".'

In fact, high liturgy can pulsate with life and increasing number of churches are reinstating traditional hymns with slightly updated texts and modernized accompaniment.

In conclusion Gibbs remarks: "As I reflect on the application of Donald McGavran's insights to the situation in the United States, I am concerned that we may have substituted marketing for mission and thereby seriously compromised the churchgrowth paradigm. A market driven approach can lead to superficial responses to deep issues. It can lead to promotion of a distorted form of the gospel that appears to meet needs yet does not challenge priorities and assumptions."

\section{The Missiological Challenge}

Finally, we must include Gibbs's description of those who respond to the missiological challenge of today. They need missiological training as if engaging in crosscultural mission. They must be committed to listen and to accept unconditionally. Their confidence must be in Christ alone and not any religious institution. They must be ready to be questioned at any point and to have their position scrutinized at close quarters. They must act out their beliefs: orthodoxy must become orthopraxis, and, rather than defensively assuming a denunciatory stance, they must be ready to notice the advantages of the postmodern thinking which, despite its ultimately self-destructive tendencies and nihilism, makes a valuable contribution in criticizing modernism.

'Sally Morgenthaler, Worship Evangelism: Inviting unbelievers into the Presence of God (Grand Rapids, MI: Zondervan, 1995), 135, quoted in ibid., 185.

${ }^{2}$ Ibid., 190. 


\section{Summary}

This chapter began by examining the contributions of the church growth school of thought that originated with Donald McGavran (1897-1991) and listed some fundamental principles and strategies of growth that have been endorsed by it.

We noticed that McGavran's introduction of this new approach to missions around the middle of last century took place at a time when the church, embattled in the unfriendly environment of modernity, was settling for little or no growth as an inevitable condition. Further, liberal theology, the rule of the day in most theological seminaries, had caused an erosion of the acceptance of biblical authority and a blurring of the church's concept of mission.

Thus, based on a recognition of full biblical authority, of the church as a divine institution and an absolutely essential and integral part of God's plan of salvation for mankind, and of mission as being the carrying out of the Gospel Commission, a divine enterprise, a finding of the lost, with its chief and irreplaceable purpose being church growth, McGavran's contribution to missions can hardly be overestimated or viewed as anything short of providential at this pivotal point in history.

Some may fear that the church growth movement has become so locked in the success orientation of the modern mentality that it will inevitably become a casualty of this cultural shift caused by the emergence of postmodernism. But as we have seen, this does not have to be the case. The church growth concept may have been strongly connected to methodology, to the fostering of purely numerical increase in the church, and to the advocacy of certain dearly cherished principles. But the roots of the church growth concept go deeper than this and have been shown not to be irrevocably tied to any methods or 
pragmatic strategies as many alterations and corrections of emphasis have taken place in the course of its existence without it losing credibility or momentum.

In this chapter I have also sought to evaluate some central principles of the theory of church growth by reviewing some well-documented studies in order to ascertain the validity of these principles and methodology and found them to be credible and of value.

I have then inserted a study of a cell movement in early Methodism, the class meeting program, that has been an inspiration for many to engage in small group programs. We noticed the effect of the class meeting in Methodism in spiritual formation and accountability of members and its contribution to the phenomenal growth of the denomination in the eighteenth and the nineteenth centuries.

At the close of the chapter we noted the monumental transition that has taken place in the latter part of the last century as the postmodern worldview has increasingly taken över that of modernism. Further we noticed that this new paradigm demands a new approach on behalf of the church if it is going to be successful in its enterprise of seeking to communicate the gospel at the present time. 


\section{CHAPTER IV}

\section{THE ADVENTIST MISSION IN ICELAND: THE INDIGENOUS MILIEU}

\section{AT ITS ARRIVAL AND ITS GROWTH AND DEVELOPMENT}

\section{Introduction}

The Advent mission entered Iceland at the turn of the twentieth century and has thus operated here for a little more than a century. But the Advent mission did obviously not enter a void at its time of arrival in Iceland. The purpose of this chapter is, first, to present a picture of the political, social, and religious milieu into which the preaching of the three angels' message entered and then, second, to summarize the historical development of the missionary activity of the Adventist Church in Iceland from its inception to the present. I will attempt to answer such basic questions as: In what way did the conditions in Iceland at the time of the arrival of the mission affect its success? What was the fundamental strategy of mission, its aims and objective, and to what extent have these been successfully carried out? To what extend was the mission sensitive to the culture in which it operated and how did it adapt to the conditions and needs of society? What were the responses and reactions of the objects of mission to the activity of the missionaries To what extent was the mission able to engage local workers and lay people in church and mission work? and, What were the results in terms of membership growth, establishment of viable, reproductive churches, and influence within society? Finally, we will briefly examine the reasons for lack of church growth in Iceland during the period 
1950-1980 as presented in a D.Min. dissertation by Steinpór Pórðarson. ${ }^{1}$

\title{
Iceland at the Time of the Arrival of the Advent Mission
}

\author{
Winds of Change--The Struggle for Independence
}

The Advent mission did not enter a void at its time of arrival in Iceland.

Adventism arrived in Iceland at the very end of the nineteenth century when the Icelandic people were in the process of being formed as a political nation after a long struggle for independence from under Danish rule. The motivating force behind this process, which got underway in the 1830s as a group of young Icelandic intellectuals and students at the university in Copenhagen became politically active, can be ascribed to the influence of currents of thought and events in Europe at the time, such as Romantic nationalism and the French revolutions. This encouraged this group of intellectuals, as they reacted against the Rationalistic Establishment, to aspire for a revival among their countrymen of national consciousness based on appreciation of their past history, tradition and language rather than this leading to religious revivals as was the case in the neighboring countries. ${ }^{2}$ This group of nationalists in Copenhagen, under the very able leadership of Jón

Sigurðsson, communicated well with the general public in Iceland through letters and magazines which they published and disseminated among the public in Iceland, very

\footnotetext{
${ }^{1}$ Steinpór Pórðarsson, "A Study of Factors Related to the Numerical Growth of the Seventh-day Adventist Church in Iceland 1950-1980" (D.Min. dissertation, Andrews University, 1985).

${ }^{2}$ Pétur Pétursson, Church and Social Change: A Study of the Secularization Process in Iceland 1830-1930 (Vanersborg: Plus Ultra, 1983), 96. Pétursson points out that similar reaction to Rationalism in the other Nordic countries took the form of religious revivals which never took place in Iceland: "During the first phase of the political nation building process in Iceland, from 1830 to 1850, the Nationalistic revival had certain social and political functions similar to the religious movements in Scandinavia. Both movements were reactions to the Rationalistic Establishment and both mobilized a broader strata of people into what might be referred to as the prelude to a democratic nation building process. The Icelandic revival was dominated by nationalistic and political overtones whereas the dominant theme in the other Nordic countries was centered around religious and theological issues." Pétursson states further: "National identity [in Iceland] was based on the historical heritage of language and literature and not on religion." Ibid., 108.
} 
often through the local pastors of the Lutheran State Church. ${ }^{1}$

Significant events during the nineteenth century which signaled important progress in the struggle for Icelandic independence were the re-establishment in 1845 of the ancient Icelandic parliament, the Alping, the symbol of past greatness, in Reykjavik, as an advisory assembly, the opening of the Theological Seminary in 1847 , and the acquisition of a new constitution at the millennial celebration in 1874 of the settlement in Iceland, handed over by the Danish king Christian IX in person. ${ }^{2}$

In almost every area of life, the nineteenth century was a period of gradual awakening of the Icelandic people as a nation from the earlier condition of social and political apathy. Enormous growth in thought and intellectual output took place as the people threw off the shackles of the past and experienced freedom of thought and expression and motivation to re-discover especially their national literary heritage and participated in a revival of the fertile vernacular.

Very rapidly, as society was opening up to new vistas and challenges, old ways and values underwent re-assessment, and rapid change in the basic structure of society started to gain momentum.

In this process of awakening of the national identity the Church certainly took an active part, but not by enhancing the Christian gospel, but rather by strengthening the

\footnotetext{
'Pétursson describes how the pastors of the State Church played a unique role in the process of Icelandic independence. The local pastor identified with the leaders of the farming community, most of them being farmers themselves, and often also represented the people in the Alping (the Icelandic parliament) and thus were not identified with the reactionary establishment, while the Bishop was linked to the Danish government. Thus the Church, its pastors and its higher officials, bridged the gap between the general public and the Danish government. Ibid., 81-98.

${ }^{2}$ These events then prepared the way for self-government granted in 1904, autonomous sovereignty and equal status to Denmark under the Danish Crown in 1918, and then full independence in 1944.
} 
national spirit in identifying closely with the people.

\section{Influence of Urbanization on Religious Life}

Radical social and economic changes also took place in Icelandic society at the close of the nineteenth century as urbanization, which had almost totally been absent in the country, started to occur. We will in the following section very briefly state some of the causes and consequences of this development.

\section{Economic Changes}

At the close of the nineteenth century farming, which had, in practically unchanged form, been the mainstay of the socio-economic structure of the country from the beginning, was no longer capable of sustaining the nation. In the beginning of the century the population started to increase after an earlier decline' but soon a limit was reached as, according to estimates, farming techniques in use at the time could not sustain more than 50,000 in the 1860 s and $1870 \mathrm{~s}$, provided all arable land was in use which seems to have been the case. But the majority of the farmers were extremely poor which meant that their operation was very sensitive to "bad years," meaning loss of livestock. and subsequent starvation.

This situation, which caused a wave of emigration to North America in the 1870s, was only to be accentuated by renewed natural disasters and ensuing crop failure in the $1880 \mathrm{~s}^{2}$ All this resulted in severe strain on the economic structure of society.

\footnotetext{
${ }^{\mathrm{I}}$ The country had gone through a series of natural catastrophes in the eighteenth century reducing its population to about 47,000 . The population had been about 51,000 a century earlier and has been estimated to have been about 70,000 the year 1100. Ibid., 22 .
}

${ }^{2}$ About 10,000 Icelanders emigrated to the United States and Canada 1870-1890. Ibid., 32. 
Furthermore, and as a consequence of what has been described above, measures used by farmers to monopolize the labor market were starting to fail. As farmers were in need of cheap labor certain restrictions had been in force for centuries regulating the class of farm laborers. ${ }^{1}$ The official reason for these measures was the prevention of overburdening of the social support system, but they served also to maintain the existing structure of society.

Fishing along the Icelandic shores, which had been very ineffective, unreliable and hazardous as it was exclusively carried out in open boats on a day-to-day basis, was by the end of the nineteenth century becoming a viable occupational alternative due to the introduction of larger, improved vessels. Traditionally fishing and farming had not been differentiated between, as fishing would only be engaged in as an additional seasonal source of income for seashore farmers or farm laborers sent to fishing sites at certain times of the year. The improved access to the resources of the sea eventually meant a movement of population from the rural areas to new costal settlements. This new development was suppressed by farmers and landowners who saw in fishing independent of farming a threat to their position and to the ordered structure of society.

As a further incentive to increased migration from the farming districts were the lifestyle and opportunities offered in the new settlements to obtain a higher standard of living where money circulated and could be earned as new employment opportunities arose: "The new towns to which the rural population was now migrating brought not only

\footnotetext{
'The main measures were the following: All laborers were obliged to make a yearly contract with a farmer. This was to prevent farm laborers, male or female, from migrating from farm to farm, negotiating higher wages at labor intensive seasons. The dependence by free laborers on additional seasonal income from fishing was frowned upon. Farm laborers could not marry without having access to land or property. Ibid., 64.
} 
new means of livelihood, but also new amusements, new interests, new associations, new divisions of the population into economic classes."

In 1860 Reykjavik, with its 1,500 inhabitants, was the only township with borough status and the only urban settlement in the country. The most intensive period of urbanization occurred in 1897-1908 and in 1910 the population of Reykjavik had reached 11,600 and there were by then four other townships with borough status. ${ }^{2}$

\section{The Influence on the Religious Life of the Nation}

As a consequence to these developments, apart from economic growth, fundamental changes took place with respect to the role and relevance of the Church and religion. First, the household, which had served as a cornerstone of the social order of the farming society, lost some of its central role. A special feature of Icelandic religious life was the traditional household devotions maintained at most farms. ${ }^{3}$ Isolation of many farms and difficult weather conditions, which frequently prevented church attendance during the long winters, may have contributed to the formation of this tradition. But in spite of its crucial role in the religious socialization of the people and maintenance of the

${ }^{1}$ Michael Fell, And Some Fell into Good Soil: A History of Christianity in Iceland (New York: Peter Lang Publishing, 1999), 226, 227. An indigenous bourgeoises of merchants had never before existed in the country as trade and commerce had almost exclusively been in the hands of foreigners who did not integrate with the social structure of society.

${ }^{2}$ Pétursson, 30.

${ }^{3}$ Pétursson includes the following revealing description of the traditional 'evening vigil' on an Icelandic farm: "In fact, the household devotions, which usually included the reading of a sermon, perhaps something from the Bible, the singing of hymns and prayer, was part of the national custom of the "wintereve gatherings" (Kvöldvaka). On these occasions the entire household gathered on winter evenings in the largest room (sometime the only livingroom) on the farmhouse, for various indoor activities including the telling of stories, folk sagas and fairy tales. Ballads, the so-called rimur, were also recited on these occasions. Narratives of Old Nordic heros and the sagas often had a part in the entertainment, mostly in popularized version. They were, for instance, often converted into popular ballads which were memorized. The evenings always ended with the short religious service as described above." Ibid., 56. 
pattern of the religious life, this tradition started to get out of fashion at the latter end of the nineteenth century and had almost disappeared in the 1930s. This development began in the new urban settlements and later spread to the whole country. ${ }^{1}$

Second, pastoral visitation, which for long was an important part in traditional religious and social structure of society, was also lost during the same time period. For long it had been the duty of the local pastor to visit each household at least twice yearly in order to check up on the basic education of children and the religious education in general and to supervise the domestic discipline. A decrease in emphasis on this practice was already noticed before the turn of the century in conjunction with decreased direct responsibility of clergy for primary education of children. This development was accentuated in the urban environment.

One could have imagined that the population, which in the rural setting through household devotions and pastoral surveillance had been so highly integrated and involved in the official religious framework, would find other ways to fulfill their religious need in the urban environment, but this seems not to have been the case. Pétursson comments: "The household devotion hours were discontinued and ... this process began in the towns and villages. The decline of the traditional form of devotions in the $19^{\text {th }}$ century was not replaced by other forms of religious involvement. On the contrary, it seems that there was a simultaneous decline in church attendance as well."2 Fell adds: "The National Church was unfortunately unable to respond promptly to the need of these resettled people for spiritual ministration in their own villages.... It is not surprising, then, that a growing

\footnotetext{
${ }^{1}$ Ibid., 58.

${ }^{2}$ Ibid., 71 .
} 
alienation took place between the new classes of townsmen and the Church. The Church was losing its central position in society, and becoming isolated from large segments of the population."1

\section{Secularization of Society}

The progressive change in society and the simultaneous decrease of the centrality of the Church's role in people's lives has been discussed above. But this was not, as also has been mentioned, caused by the identification of the Church by the common people with the oppressing foreign power. As Fell points out:

In the nineteenth-century struggle for self-government, the priests and the bishops of the Church stood shoulder to shoulder with the common people. Many priests served as members of the Alping, working for Icelandic self-government to the best of their ability. Here was one more bond between priest and laity... . The concern of the people at large shifted away from an interest in the Church for its own sake. In so far as people broadened their vision beyond their own immediate personal and family affairs, it was primarily the independence movement that claimed their attention. The support and affection felt for the Church was strongly colored, in the minds of a majority of the people, by the support that the priests and bishops of the Church gave to the movement for self-government. Church affairs for their own sake came to arouse only a peripheral interest. ${ }^{2}$

The estrangement between Church and society occurred as institutions which earlier were under the control of the Church and the clergy became secular (e.g., the educational system and local government, due to increased differentiation of society). From being the most dominating single factor in the maintenance of its social structure the Church increasingly became less central to the socio-political development of the emerging nation, a common tale in the Western world. Let it suffice to mention shortly the development with regard to primary education and local government.

\footnotetext{
${ }^{1}$ Fell, 228.

${ }^{2}$ Ibid., 227, 228.
} 


\section{Primary Education}

Until 1880 primary education was entirely under the supervision of the clergy, and only reading and thorough knowledge of the catechism by the age of fourteen (i.e., prior to confirmation) was required by law. The instruction was quite often carried out by the pastor himself. In 1880 mandatory education was extended to include writing and elementary arithmetic. The responsibility for primary education was then gradually transferred to the communal councils with the pastor serving as the chairman of the board of the soon emerging primary schools.

\section{Local Government}

This process of transferral of the engagement of the clergy in education coincided with the establishment of new forms of local government of which the church and the clergy were no longer automatically a part. The local pastors had, as a rule, been either regular members of or consultants of the local communal committees and councils. A change took place at the latter part of the nineteenth century as communal councils were being formed through democratic elections where clergy could be elected but were not automatically members. This process of departure from clergy involvement in local government was most rapid in urban settlements.

This took place at the same time as clergy were increasingly being displaced in other civil functions which, due to their general knowledge, they had fulfilled as other specialized personnel were not available, such as the practice of medicine. ${ }^{1}$

1"In discussing the various non-ecclesiastical activities of the clergy, one leading clergyman ... wrote that the medical advisory activity was warranted by the lack of professional physicians. Furthermore, he considered it compatible with the role of the clergy in 'following Jesus' footsteps.' He maintained that the clergy were more qualified than other lay-physicians because they were less tempted to overestimate their own capacity." Ibid., 69, 70. 
In summarizing the effect of these developments, Pétursson states: “The disengagement of the various social functions from the role of the clergy and the desacralization of education and social control was associated with decreased involvement in the traditional form of religion.... As for the parishioners, the situation could be defined in no other way than the church was losing its control over the people."”

\title{
Dawn of Religious Pluralism in Iceland
}

\author{
Dissatisfaction with the Church and the Emergence \\ of Religious Pluralism
}

At the turn of the twentieth century a growing dissatisfaction with the role and the performance of the established Church becomes prevalent. This may have been caused partly by the inability of the Church to meet the spiritual need of the rapidly changing society as has been described above. But other factors were also at work, such as the intellectual spirit of the time. Intellectual winds from abroad were affecting the nation, and increased demands for freedom met by changes in legislation finally led to religious pluralism in the country.

Students at the university in Copenhagen during the last decades of the ninteenth century came into contact with the liberal thought patterns of the age, such as radical antichurch Realism and religious Liberalism together with anti-officialism and the spirit of democracy that flourished at the time. ${ }^{2}$ A flood of liberalistic, even atheistic ideas were spread in Iceland through a host of papers, many of which were published from

\section{${ }^{1}$ Ibid., 75.}

${ }^{2}$ The watchwords of the Icelandic students in Copenhagen, under the influence of radical realists such as Georg Brandes (1842-1927), were self-respect and self-assertion, whereas the watchwords of the Church had been humility and loyalty to the Christian tradition. Fell, 229. 
Copenhagen or edited by former students of the university of Copenhagen. ${ }^{1}$ The general response to this influence was varied. Fell describes it thus:

Many, especially among the intellectuals and governing classes, became indifferent to religious matters; they now felt more justified than ever in not bothering their heads with the deeper issues of life. On the other hand there was also a widespread response of indignation and even grief. It was widely held that the national morality and piety were on the verge of collapse; and there was a deep sense of dissatisfaction with the National Church because of its apparent inability to satisfy the religious needs of the people. ${ }^{2}$

Many thinking individuals who felt deeply about the issue sensed an impending national religious crisis in Iceland at this time which led to an earnest search for a solution. Pétursson points out that "the opposition to the State Church and the official religious model in Iceland was not theologically motivated; rather it was directed against the hegemony of the leadership and the authoritarian government of the Church." An indication of this, he feels, is the emergence of the "Free-Church" ideology which must be seen as a sincere attempt by its instigators to present a solution at a critical time. To this movement we must now turn our attention, which again became an opening wedge to religious pluralism.

\section{The Free-Church Movement and Religious Pluralism}

Inevitably the development I have been describing above led to the loss by the State Church of its position of monopoly of religion in Iceland. But the first attempt of non-Lutheran religious groups (Roman Catholicism and Mormons) to set root in Iceland

\footnotetext{
'In the 1880 s, six papers were founded all of which forwarded liberalist critique of the official religious model in one form or another. These were Fjallkonan, Suðri, Fróði, Norðurljósið, Austri and pjódviljinn. Some of the articles were from time to time associated with the attitudes of free-thinkers and dealt with "religious truths" from the point of view of comparative religion (especially Fjallkonan from 1884). Pétursson, 111.
}

${ }^{2}$ Fell, 234, 235. 
by the mid-nineteenth century had certainly met with strong opposition both by political and ecclesiastical authorities, ${ }^{1}$ despite the fact that the Danish constitution, which strictly speaking also was in force in Iceland, allowed for freedom of religion. ${ }^{2}$

In the 1880s a very different development took place in the east of the country (in Hólma parish in Reyðarfjörður) which eventually opened the way for democratization of the Church and at the same time the breaking of religious monopoly in the country. The issue concerned controversy over the matter of pastoral election which led to the withdrawal of membership by a group of parishioners from the State Church (thus exerting their constitutional right from 1874 granting freedom of religion) and the forming of their own governing committee. The difficult matter of finding a pastor for the congregation was solved as a Lutheran pastor, Rev. Lárus Halldórsson, who had recently left his office as dean of the State Church, became available. ${ }^{3}$ The discussion concerning the rights of the members of this and other ensuing Free-Church congregations in the Alping eventually led to a bill being passed in 1886 granting a right to civil marriage in the case where one or both parties were outside the State Church, the legality of services rendered by pastors of independent congregations and a relief for members of

\footnotetext{
${ }^{\mathrm{I}}$ The mood of the generality of Icelanders in regard to religious pluralism in the 1860 s was well expressed by the nationalistic Justice Benedikt Sveinsson (1827-1899) when he declared that it was "unlawful for an Icelander to cast off his Evangelical Lutheran faith, and, furthermore, illegal for anyone to urge an Icelander to do so. Icelandic converts would automatically lose their right of inheritance and even their right to remain in the country. They were to leave immediately, with police force if necessary, never to return." Pétursson, 144.

${ }^{2}$ Freedom of religion was granted by the Danish constitution in 1849 and should in a sense have applied throughout the realm but according to the Icelandic officials the law was not in force in Iceland. Religious freedom was thus first introduced in Iceland with the new constitution of 1874.

${ }^{3}$ Pétursson, 115-117. See further discussion about pastor Halldórsson, as he would later work closely with the first Adventist missionary, David Östlund.
} 
independent congregations from payment of taxes and fees to the State Church. ${ }^{1}$

These laws meant a radical change in the formal position of the Church and its relation to the State. Pétursson emphasizes the significance of this legislature in the following: "The monopoly claims of the official religious model in areas of theology and social order were de facto rejected. Its dogma was no longer granted an absolute status in the country; the state could approve other religious bodies. In theory, this legislature meant the desacralization of some of the most vital mechanisms of the social order."2 Among the members of the Alping to pass this bill was none other than Rev. Lárus Halldórsson himself, who served for five years (1886-1891) as a representative of the district of Suður Múlasýsla at the parliament. He thus played a key role in these important developments of such singular importance to the future of the religious life in Iceland. To this man of intellect, vision and character we will now turn our attention, as a short overview of his ambitions and accomplishments in life will help us gain an insight into the peculiar situation in Icelandic religious life at the turn of the century.

\section{Rev. Lárus Halldórsson}

Lárus Halldórsson (1851-1908) received a Cand Theol from the seminary in Iceland in 1873 and started his career by serving as secretary of the bishop (1874-1877). He then became a pastor of the Valpjófsdal benefice in the East of Iceland in 1877 and was appointed dean of the area in 1878 . Then a sudden change occurred in his successful career as parishioners forwarded a complaint to the bishop concerning his conduct: "For some time Rev. L. Halldórsson had been in conflict with some of his parishioners and the

\footnotetext{
${ }^{1}$ Ibid., 117, 118.

${ }^{2}$ Ibid., 118.
} 
Church authorities over Church ritual and ceremony. He opposed the use of mass

vestment and alter service. According to him these were remnants of Catholicism and 'Danish superstition'."'

Rev. Halldórsson had the choice of terminating his service for the State Church or to disavow his convictions. At a similar time the need arose, as mentioned earlier, for a new pastor for an independent congregation at Hólma parish, a golden opportunity which Rev. Halldórsson seized. ${ }^{2}$ But the interests of the parishioners and the pastor did only partially overlap. Theirs was the issue of a democratic right to determine their own pastor but soon it became apparent that he had a much more comprehensive program in mind. Rev. Halldórsson had come to know the Free-Church movement in Scandinavia ${ }^{3}$ but he was particularly well acquainted with the way churches operated in North America and had connections with two significant church leaders among the Icelandic population in North America, Rev. Jón Bjarnason and Rev. Friðrik Bergmann. His relationship with Rev. Bjarnason was especially close. ${ }^{4}$ Fell says about Rev. Bjarnason:

The foremost and most influential churchman among the emigrants was Séra Jón Bjarnason (1845-1914), a strong and determined leader who had been ordained to the priesthood in Iceland before emigrating, and in 1885 became the first president of the

\footnotetext{
${ }^{1}$ Pétursson, 145. It is interesting to note on what points Rev. Halldórsson took issue with the established Church, namely vestments, baptism and the Lord's Supper, points that suggest that he may have been significantly at variance with the theological understanding of the church. See Guðjón S. Björgvinsson, "Vér undirskrifaðir," Saga Frikirkjunnar i Reykjavík, Reykjavik, 1999, unpublished paper, 28.

${ }^{2}$ Authorities are of the opinion that even though Rev. Halldórsson's arrival at his convictions was entirely unrelated to the events at the Hólma parish his determination to carry them through in spite of impending dismissal from the State Church was likely to be influenced by the prospects of employment by the independent group. See Pétursson, 146; Björgvinsson, 29; Karl Sigurbjörnsson, Fyrsta Frikirkjan á Íslandi, Reykjavik, 1973, unpublished paper, 66. Iceland, 1982, 33.

${ }^{3}$ Jónas Gíslason, Stutt ágrip af sögu íslensku kirkjunnar á fyrri hluta 20. aldar, University of

${ }^{4}$ Their wives were sisters.
} 
newly-founded Icelandic Lutheran Church Association in North America. His dearest wish was to keep alive the ties of language, culture, and religion binding the "west Icelanders" [Icelandic emigrants in North-America] to their mother country; and in the process he mercilessly criticized the shortcomings of the mother Church in Iceland. The major development in Iceland to which his criticisms contributed was the Free Church movement. ${ }^{1}$

These men worked together on what they were convinced would be a solution for the church in Iceland. ${ }^{2}$

Close to the turn of the century a growing discontent arose in Reykjavik with state control over the Cathedral Church. Björgvinsson summarizes the key elements of criticism: The Cathedral Church, the only church in Reykjavík at the time, was not providing the spiritual nurture needed for its parishioners; class distinction in the Church was obvious, this being the only social contact between the ruling class of government officials and wealthy merchants still controlled by Danes and the common class; well to do craftsmen and tradesmen of the emerging Icelandic middle class voiced their resentment to foreign control and the sluggishness and lethargy of the Church and wanted to create a new congregation, an Icelandic Church of vibrant religion; further, they protested against increased church taxation of 1899 and lastly but not the least, Rev. Halldórsson had shown himself to be a dynamic and enthusiastic leader of strong faith, a man of experience having pioneered the church in Reyðarfjörður. Doubtless the activities

${ }^{1}$ Fell, 280. Rev. Bjarnason actually moved back to Iceland pastoring churches in Seyðis- and Mjóifjörður 1879-1884, neighboring towns of Hólma parish in Reyðarfjörður where Rev. Halldórsson pastored the first Free-Church in Iceland from 1884. In 1884 Rev. Bjarnason transferred back to Winnipeg, Canada. See Björgvinsson, 33.

${ }^{2}$ It has been shown that there was striking similarity between the constitution and bylaws for the Free-Church in Reyðarfjörður and a proposed Icelandic Church Association to be organized in North America in 1877, most likely under the influence of Rev. Bjarnason, which did not materialize until 1885 as mentioned above. Then again the constitution and bylaws of the Free-Church which Rev. Halldórsson established in Reykjavik 1899 were almost identical to the those in Reyðarfjörður. Björgvinsson, 33. 
of emerging new religious bodies in the country at the time ${ }^{1}$ were instrumental in fueling the discontent with the performance of the State Church. ${ }^{2}$

These developments eventually led to the launching of a Free Church congregation in Reykjavik in 1899. In late September that year, shortly prior to its organization, a general meeting was called in Reykjavik by the initiative of the leaders of the State Church where the general public was invited to air their opinions and grievances concerning the state of church affairs in Reykjavik at the time. Many prominent people attended, among them the pastor of the Cathedral Church and Rev. Lárus Halldórsson, but the main speaker at the meeting was Rev. Jón Bjarnason who had arrived, together with Rev. Friðrik J. Bergmann, from America to forward his views on matters of the Church. It may partly be traced to the effect of this meeting that a Free Church was formed just a few weeks later. But from there it becomes apparent that the ideological leaders of this "uprising," as this whole enterprise of establishing the new church was called, envisioned something much more radical than just the resolution of grievances perceived by the Cathedral congregation. They were seeking a solution for the Church in Iceland in general by, in fact, calling for a complete separation of Church and state. They held the leadership of the Icelandic Church accountable for the degeneration of Christianity in Iceland and were convinced that much of the problems of the religious life in Iceland could be blamed on the state church dichotomy. ${ }^{3}$ Rev. Lárus Halldórsson makes this plain in the opening issue of the Free Church periodical Frikirkjan (The Free-

\footnotetext{
'Such as the Salvation Army (1895), the Catholics' renewed missionary effort (1896), the Adventists (1897), Plymouth Brethren (1898), and the YMCA and YWCA (1899).

${ }^{2}$ Gislason, 33.

${ }^{3}$ Pétursson, 128, 129.
} 
Church) and even touches on the sensitive issue of finances stating that the true spirit of

Christianity cannot flourish in a Church that is controlled and supported by the state:

All those who prize Christian faith will agree in aspiring after as abundant a growth in faith as possible. But there is one factor that, even by itself, strengthens one's faith considerably-and that is the awareness of not being dependent on the support of the state, either individually or as a congregation. With such an awareness one's heart turns much more fully toward him who has promised to be with his own unto the very end. Then one places all one's trust in him. ${ }^{1}$

In order to fully comprehend the radical nature of such a statement at the time one must contrast it with a discussion that had taken place in Iceland just a few years earlier where a prominent individual within the Church had defended the traditional StateChurch relations by referring to the influential Danish theologian, bishop H. L. Martensen $(1808-1884),{ }^{2}$ who he claimed that the moral order of society was based on the cooperation of church and state, and that those demanding separation were either heretics or atheists. ${ }^{3}$

Thus the spirit of religious freedom was very much at the core of the program of Rev. Halldórsson, a sentiment also very prominent in Adventism, and in fact there was close cooperation on this and other issues between the first Adventist missionary, David Östlund, and Rev. Halldórsson as will be discussed later.

\footnotetext{
${ }^{1}$ Rev. Lárus Halldórsson, quoted in Fell, 281.
}

${ }^{2}$ Hans L. Martensen was a bishop of Seeland and a very influential theologian in Denmark around the middle of the $19^{\text {th }}$ century. His theological program of Neo-Orthodoxy aimed to set forth a complete reconciliation of faith and knowledge, his basic principle being taken from Hegelian dialectics, assuming the final unity of all things as determined by the eternal will of God. His influence in Denmark (called the Third Church Policy Program, the others being Grundtvigianism and Inner-Mission) diminished due to criticism of Kierkegård and others but it was actually the only church policy in Iceland during the secondhalf of the $19^{\text {th }}$ century. See Pétursson, 111, 112; Fell, 207, 218, 219.

${ }^{3}$ Rev. Pórarinn Böðvarsson (member of the Alping 1869-1894) presented this claim in an article in the magazine Kirkjutíðindi in 1883 in connection with a debate arising from the increasing critique of the official religious model. Among the participants was Jón Ólafsson, a member of the Free-Church in Reyðarfjörður. Pétursson, 128. 
Furthermore, Rev. Halldórsson was a seeker after truth who endeavored to bring about revival of personal faith in the Free Church congregation at a time of spiritual dearth in Iceland. He was a firm believer in the full inspiration of the Bible which became apparent in his participation in a public debate at that time concerning the inspiration of the Old Testament and its role in Christian theology, and he was an ardent student of God's word in search of truth. His acceptance of some Adventist doctrines was well known, such as the observance of the seventh-day Sabbath. ${ }^{1}$ This open attitude had originally caused his dismissal from the State Church benefice as already mentioned and it probably also caused his dismissal from the Free Church after little more than three years of service.

The vision of Rev. Halldórsson never materialized in the Free Church in Reykjavik, being a man ahead of his time. It was a case of conflicting expectations between the congregation and himself. His congregational church constitution of a fully independent Evangelical Lutheran congregation and earnest spiritual emphasis never caught the imagination of the majority of the members who were fully satisfied having achieved the right to elect their own pastor but otherwise to remain fully within the liturgical and theological tradition of the State Church. It is said that when Rev. Halldórsson wanted to conduct church services without vestments and to have the alter removed from the church that the members turned against him. ${ }^{2}$

\footnotetext{
${ }^{1}$ When Rev. Lárus Halldórsson and his family moved from the East of Iceland to Reykjavik they started to attend a Bible study group in the home of the Adventist missionary, David Östlund. Rev. Halldórsson and all his family kept the Sabbath faithfully all their life in spite of considerable opposition. Björgvin Snorrason, “The Three Angels' Messages Reach Iceland” (research paper, Seventh-day Adventist Theological Seminary, Andrews University, 1986), 31.

${ }^{2}$ Gíslason, 33, 34.
} 
A man of great ability was elected as pastor for the Free Church in Reykjavik as Rev. Halldórsson's successor, and the congregation grew during the coming years to the point of overtaking the Cathedral Church in size. Its proclamation and liturgy have always been fully in line with that of the State Church but it has shown more tolerance towards diverging viewpoints than other Lutheran Churches, for example it was the forum where spiritualism was first systematically proclaimed in Iceland by Rev. Haraldur Níelson, the most fervent proclaimer of those views.

\section{Liberal Theology-The Church's Bid for Renewal \\ The Defense of the National Church}

As we have seen the Church in Iceland at the time centering around 1900 was at a very low ebb and was being attacked from all sides. The very rapid social and political changes and developments that were taking place in Iceland had insulated the church and left it out of touch with society. This did not diminish religious interest in the country. The Christian religion had always been a significant factor in the life of the nation, and people could not imagine life without its involvement. But there was an outcry from all sides for congruity by the Church to the present need: "What we observe as we move towards the end of the $19^{\text {th }}$ century and the beginning of the $20^{\text {th }}$ is an increase in interest for religious matters, an interest synchronous with the increasing religious pluralism. This interest was not anti-Christian even though it was alienated to a great extent from the established religious institution."1

The general public sought for a relevant Church that would provide meaning and

'Pétursson, 158. 
give comfort in a rapidly changing society of explosive urbanization and ensuing rootlessness and social problems and uncertainty in the midst of a confusing influx of foreign religious groups that started to solicit people's attention after the removal of the monopoly on religion by the Evangelical Lutheran Church.

One of those who were concerned about the dismal state of the Church was a Seminary professor in Reykjavík, a young man rising to leadership within the Church at the time, Jón Helgason (1866-1942), who was to become one of the most influential architects of the Church in Iceland in the new century. Rev. Helgason was well aware of the sentiments in Copenhagen as he had received his education there. He had also studied for a short time in 1894 in Germany in preparation for his teaching job at the Seminary. There he got acquainted with the views of German liberal theology and the hermeneutical method of Higher Criticism. Those sorts of sentiments were not permissible at the conservative Theological Faculty in Copenhagen but as it turned out, Rev. Helgason started to introduce these crucial theological issues in Iceland, maintaining the stand of the liberal theologians and applying their historical critical methods.

In retrospect, even though the first release of Rev. Helgason of these ideas came unexpectedly, one must see this as an honest attempt on his part to radically reshape a Church in the throes of woe by making it shed its old and, in his opinion, outdated notions thus enabling it to answer the questions of and to speak meaningfully to a new age of scientific materialism and realism. This entailed the elimination of the doctrines which the liberals considered most objectionable and elements in the biblical narrative and Christian theology in the light of newest scientific research and philosophical discussion of the day. But, according in Rev. Helgason and his associates of similar 
sentiment, this was a matter of rescuing an otherwise doomed enterprise. But by making the Church speak a new language he thought it just might be adapted to adequately meet whatever critique it was being bombarded with and answer with authority the cacophonous voices of religious plurality.

Jón Helgason and David Östlund

As it happened, it was the message of the newly arrived Adventist missionary, David Östlund (1870-1931), that sparked this process. ${ }^{1}$ Östlund, arriving in the country in November 1897 , was a man of extraordinary ability in many respects, an outstanding orator and a brilliant linguist and very quickly he had acquired remarkable command of the Icelandic language. His lectures became very popular in Reykjavik and the novelty of his message caused wide attention. ${ }^{2}$ In the fall of 1898 Östlund also published a small book on the Sabbath entitled Hvidardagur Drottins og helgihald hans fyrr og nú (The Lord's Sabbath and Its Observance in Earlier Times and at Present). ${ }^{3}$ Rev. Helgason decided to answer his polemic on the Sabbath question publicly in his magazine Verði ljós

\footnotetext{
${ }^{1}$ Due to its bearing on the present discussion I will include here an account of Östlund's interchange with Rev. Helgason while all further mention of his contribution will be reserved for the next chapter.

${ }^{2}$ The following excerpts from the newspapers in Reykjavik at the time are quoted in Björgvin Snorrason, "Pastor David Östlund and the Beginnings of the Seventh-day Adventist Church in Iceland," (Andrews University, School of Graduate Studies, 1975), 14, 15. "Mr. Östlund must be exeptionally brilliant at learning foreign languages. He arrived here late in November last year. He had then learned a little in the Icelandic Bible, without any instruction, and without having any clue as to how to pronounce a single word in Icelandic. Now he lectures in Icelandic, not only so clearly and distinctly that every Icelander understands him, but also incredibly faultless, both with regard to idioms and phraseology. He speaks kindly, composedly and dispassionately. The meetings which he has held here this winter have been so frequenated that housing accommodation has been a problem." Editorial, Ísafold, February 12, 1898, p. 31. "David Östlund ... is an excellent orator ... a young man, well educated and a true gentleman. If his doctrine was not so unacceptable and peculiar as it is, then men of Mr. Östlund's character would be successful in soul-hunting." Editorial, pjóðólfur, Jan. 22, 1898, p. 20.

${ }^{3}$ Snorrason, "Pastor David Östlund and the Beginnings of the Seventh-day Adventist Church in Iceland," 22.
} 
(Let There Be Light). He may have felt, first, that it was high time that the Church answer some of the attacks leveled against her, second, that the curious doctrines of the Adventists would be easily refuted.

Certainly it looked to be an unequal match: The most brilliant scholar of the Icelandic Church, a professor at the Theological Seminary, taking on a young foreigner of limited formal theological training still in his twenties. But quickly Rev. Helgason discovered that he had misjudged the situation. Östlund exhibited great knowledge of Scripture which seems to have startled Helgason. Then most of his arguments on the Sabbath issue were by necessity gathered in the Old Testament, the study of which Icelandic theologians had not devoted much time, as that was not even an obligatory subject in the Seminary until $1895 .^{\prime}$

Then events took an unexpected turn as Rev. Helgason, in order to silence Östlund's skillful arguments based on Scripture, in the words of Pétursson, "reached for arguments in the arsenal of Biblical Criticism." At any rate it seems as if this confrontation of Rev. Helgason with Östlund did incite him to further commitment to the study and the adoption of the methods of liberal theology. Gíslason says about this (in an approximate translation from Icelandic):

[After the debate with Östlund in the papers] Jón Helgason now committed himself wholeheartedly and in the scrupulous way so characteristic of him to the study of most recent Lutheran publications on the interpretation of the Old Testament. There he encountered the radical approach said to have originated in Tubingen in Germany.

\section{'Gíslason, 30.}

${ }^{2}$ Pétursson, 159. Pétursson seeks to put the ramifications of the polemic between Rev. Helgason and Östlund regarding the emergence and consequent acceptance of liberal theology in Iceland into perspective by stating further: "Even if the skilful arguments of the Adventist D. Östlund (there were some who maintained that he was in the right even though the issue was not judged to be very important: see Nýja Öldin II, 15, 1899) might be considered the precipitating factor, the origin and development of Liberal Theology in Iceland cannot be understood unless one takes a wider perspective in the issue." 
There Rev. Jón [Helgason] was introduced to Liberal Theology and her main teachings and adapted them. Apparently he had little knowledge of these teachings before this as during his school years in Copenhagen conservative theology dominated the Theological Faculty there.'

The arguments used by Rev. Helgason obviously necessitated the undermining of the full inspirational authority of Scripture, favoring rather to bring the issues in question to the court of reason and science thus attempting to deal a fatal blow to Östlund's argumentation which was built entirely on the testimony of the Bible and history.

A rather extensive polemic ensued which caused quite a stir. Shortly after this, Rev. Helgason started a series on Liberal Theology in his magazine, or in the beginning of 1899, and he also presented the matter at Pastors' Conventions of the Church (1899 and 1900). A heated debate arose in the Church where among others Rev. Lárus Halldórsson ${ }^{2}$ and David Östlund took part, but very few came to the support of Rev. Helgason to begin with. ${ }^{3}$ That would change, as within a relative short time the leading personalities of the Icelandic Church had accepted Liberal Theology. Among them was Rev. Haraldur Nílsson (1868-1928). By 1906 Rev. Helgason together with the President of the Theological Seminary, Pórhallur Bjarnason (1855-1916), later bishop (1908-1916), published a magazine together (Nýtt kirkjublað) "which was clearly edited in the spirit of Liberal Theology." ${ }^{4}$ Soon after this Liberal Theology was the order of the day at the Theological Seminary, later the Theological Faculty of the University (established 1911)

\footnotetext{
${ }^{1}$ Gíslason, 30.

${ }^{2}$ Björgvinsson, 29.

${ }^{3}$ Gíslason, 31 .

${ }^{4}$ Pétursson, 159.
} 
with Rev. Haraldur Níelsson as professor. This remained so until the 1940s. ${ }^{1}$

\section{Haraldur Níelsson and Spiritualism in Iceland}

Haraldur Níelsson (1868-1928) was one of the first theologians to accept Liberal

Theology but he was never comfortable with the rejection of the miraculous and the supernatural in the name of rationalism that strict adherence to it entailed. But as the Bible had become in his mind, after he had adopted Liberal Theology, only an imperfect human document and as he now questioned various traditional dogmas of the Church, there was a way open for him to embrace Spiritualism when he at this time became acquainted with it. ${ }^{2}$ This was to him "a beam of light." Here was the long-sought-for key to introduce Christianity to the scientific mind; it was to him the link between Liberal Theology and the supernatural:

Both of these movements, spiritualism and liberal theology, were at rock bottom parts of an enterprise that was very fashionable at the turn of the century - to make religion scientific, to find new avenues for presenting it so that it would appeal to modern scientifically-minded people who were becoming alienated from the traditional Church.... Since the reality of life after death was one of the keystones of Christian belief, would not a scientific proof of the survival of bodily death increase immensely the credibility of the Christian religion? $?^{3}$

Rev. Nílsson and the spiritualists could now maintain their belief in the supernatural aspects of the biblical account and still adhere to "scientific religion" as, according to them, "the miracles and supernatural events of the Bible were much the same

${ }^{1}$ Ibid., 161 .

${ }^{2}$ The main instigator of spiritualism in Iceland was Einar Hjörleifsson Kvaran after having studied the 1400 page work of F. W. H. Mayers, The Human Personality and its Survival of Bodily Death. He was an excellent writer and magazine editor (Norðurland, Fjallkonan). He, Rev. Haraldur Níelsson, and Björn Jónsson, also a prominent writer and the editor of the magazine Ísafold, dominated the initial core group who establish the Experimental Society around 1904. Gíslason, 40.

${ }^{3}$ Fell, 245, 246. 
kind of phenomena as those observed in their seances." "The conclusions of their research were, that "true faith was not contrary to science," hence their claim to being both psychic researchers and Liberal Theologians. ${ }^{2}$

Rev. Nílsson and others established the so-called Experimental Society (ES) where spiritualistic seances were held (see note on previous page). The emphasis was said to be on the worship of God, but is was a novel way of worshiping God

in which, through the agency of the medium, the living and the departed were joined together in a worshipful communion. In this way men and women were to be freed from the tyranny of materialism. A departed spirit, once it had taken possession of the medium, would serve as a kind of liturgical director, leading the devotional service that followed, deciding what prayers and hymns should be said and sung, and also preaching to the congregation through the medium. If spiritual healing were needed, the spirit leader would summon a deceased "spirit doctor."

The ES and the spiritualistic movement very early on were much more than scientific research endeavors. Their work took on much more the character of a revivalist sect. The ES was discontinued in 1912 but in 1914 Rev. Níelsson was allowed to start a bi-weekly preaching program in the Free Church building in Reykjavik. The content of these lectures was based on the spiritualistic message and they became immensely popular in Reykjavík as Rev. Níelsson was an outstanding orator. This preaching program continued till his death in 1928.

In 1918, as interest in spiritualism was increasing, an Iceland Society for Psychic Research (ISPR) was founded. The influence of the lectures in the Free Church and the activity of the Society was spread throughout the entire country. Collections of sermons by

\footnotetext{
${ }^{1}$ Pétursson, 178.

${ }^{2}$ Ibid., 179.

${ }^{3}$ Fell, 248.
} 
Rev. Níelsson were even used in traditional household worships in some rural areas. The basic source of inspiration for these sermons was spiritualism. It has in fact been maintained that Nielsson was the initiator of the only popular nation-wide religious revival in Iceland. ${ }^{1}$

Somehow this program struck a cord with many in the nation even though they never became members of the ES or the ISPR. Among the reasons for widespread support was that Rev. Nielsson, as earlier mentioned, became theology professor at the Seminary and later the Theological Faculty, and two of his graduates, both convinced spiritualists, became in turn also Theological Faculty members. This message was thus disseminated throughout the country as the theological graduates of spiritualistic persuasion were ordained and employed by the Church.

Many were to protest against this development of spiritualism in Iceland, especially to begin with. One of its most vigorous opponents was David Östlund, the Adventist missionary, as also were the leaders of the YMCA/YWCA and the Inner Mission. Rev. Jón Helgason always opposed the Spiritualistic movement. Being a teacher at the Seminary and later at the University and finally becoming bishop (1917-1938) he tried to make his influence felt but to little avail..$^{2}$ In fact he was not able to stand against

'Pétursson, 179; Fell, 249.

${ }^{2}$ During a lecture at an international conference of psychic researchers in Denmark Rev. Nielsson mentioned the positive attitude of the former bishop of Iceland, Hallgrimur Sveinsson, to spiritualism. Due to a misunderstanding, the newspapers omitted the name of the bishop so many took this to mean the present bishop, Rev. Jón Helgason. His immediate reaction was a scathing article where he corrected the mistake and denounced the whole movement, saying among other things: "The truth is that from the first time I read about spiritualism, this distasteful phenomenon of our time, I have been wholly opposed to it and to everything its followers engage in. In my eyes spiritualism is a surrogate religion of the poorest kind and the so-called knowledge it purports to bring to us from the other side pure nonsense and of no value to men as God has through his Spirit let his 'knowledge of God's glory shine in their hearts in the face of Jesus Christ.' All the claims of spiritualism to be scientific and produce scientific proofs seems to me pure absurdity." Gíslason, 47. 
its growth and even infiltration of the Church. Now it became clear that the only solid base on which to denounce and condemn Spiritualism was the foundation and at the same time the weapon which Rev. Helgason had voluntarily and fatefully disarmed himself of in his contest with Östlund earlier in dealing with the Sabbath question, namely the authority and the full inspiration of Scripture.

\section{The YMCA/YWCA and the Inner Mission}

We must mention shortly the contribution to the religious life made by Rev. Friðrik Frioriksson (1868-1961) and the YMCA/YWCA which was really an outgrowth of the Inner Mission work in Denmark.

As a reaction to the sad state of affairs with regard to work for children and youth in Reykjavik before the turn of the century Rev. Pórhallur Bjarnason, then the president of the Theological Seminary, sent a letter to a young Icelander, Friðrik Friðriksson, then studying in Copenhagen and at the same time very much engaged in youth work with the YMCA there. ${ }^{1}$ Friðriksson responded to the call and the YMCA/YWCA was established in Iceland in 1899 in close connection with the National Church. So much so that it could be looked upon as the youth branch of the Church. ${ }^{2}$ Friðriksson's work in Reykjavik met with immediate success so much so that "within one year the youth society included more than two-thirds of all the boys in Reykjavík between the ages of 12 and 16 years."3

\footnotetext{
1، The man who successfully transplanted to Iceland the liberal approach of the Danish YMCA was Friðrik Friðriksson (1868-1961). As a young University student in Copenhagen he met Olfert Richard and became captivated by and deeply involved in the work of the YMCA there." Fell, 258.

2“"Most Christian work among the childern and teenagers of Reykjavík was thus conducted under the auspices of the YMCA in close cooperation with the parish government of the city. Since then, the YMCA Sunday school and the youth divisions of the society were regarded more or less as a part of the National Church and belonged to the parish work in Reykjavik." Pétursson, 172.

${ }^{3}$ Ibid., 164.
} 
Pétursson suggests several reasons for this success. One was the method of recruiting members below seventeen years of age and that Friðriksson was endowed with outstanding charismatic leader qualities. Friðriksson, being a Seminary student, was also associated with the clergy of the Church whom the population traditionally trusted with the education and the supervision of the upbringing of the youth. Further, the movement was an Icelandic one. Even though the YMCA in Iceland had close ties to the Inner Mission leadership in Denmark, this fact was not made public so as not to throw negative light on the movement, as everything Danish was regarded with suspicion at the time. The YMCA/YWCA never worked closely with any of the new non-Lutheran Christian groups that were entering the country. The success experienced by the movement in Reykjavik was a social and religious revival among the youth, many of whom became successful leading individuals in society. ${ }^{1}$

Finally, the theological base of the YMCA/YWCA was an orthodox one and thus it opposed strongly the introduction of Liberal Theology and later it sought to combat Spiritualism. This movement had in fact much in common with church leaders in North America who for years sought to reform the Icelandic Church. Pétursson states:

In many ways this ideology was similar to that of the Icelandic clergymen in $\mathrm{N}$. America who, since the $1880 \mathrm{~s}$, had been critical of church life in Iceland. They too had propagated active mission work and religious revival and in theological disputes the leaders of the Icelandic Lutheran Church in N. America joined this front in its critique of Liberal Theology and the Church leadership in Iceland. During the first two decades of the century, this front occasionally suggested separation of church and state as

\footnotetext{
I'In his teachings, Friðriksson placed heavy emphasis on moral upgrading of 'his boys', the teenagers of Reykjavík. He wanted them to be the model of proper conduct, orderliness, obedience, abstinence, thriftiness and cooperation. His work was much appreciated by the parents and business leaders of Reykjavik, and Friðriksson was generally looked upon as the "moral reformer of the youth."” Pétursson, 170.
} 
means of improving the Christian life of the nation. ${ }^{1}$

It is safe to say that the influence of the work of the YMCA/YWCA in conserving the position of the National Church, and its stabilizing effect on all religious life in the country during these tumultuous times was immense.

\section{Summary}

The last decade of the nineteenth century and the first of the twentieth, the time when the third angel's message was introduced into Iceland, was a time when Icelandic society was undergoing radical changes in most areas as I have tried to describe so far in this chapter. The nation was being subjected to an influx of new concepts and ideas, gaining renewed national optimism and engaging in an all-encompassing quest for independence. This led to social and economical progress and urbanization which was causing a revolution in the daily life of many people. It was a time of insatiable thirst for information and growing confidence in scientific knowledge. But all this coincided with the National Church becoming weaker, its role awaiting a radical redefinition in an increasingly secularized society.

This process may have brought with it economical, social and spiritual liberation from earlier stupor and stagnation but was also instrumental in altering fundamentally people's view of life and their spiritual reality. The onslaught of a proliferation of new philosophical and religious concepts hit the nation at the core of its being, not the least as the introduction of scientific materialism had lured the Lutheran State Church to seek revitalization and renewed relevance in Liberal Theology and later Spiritualism. This was 
a time of great uncertainty for many, a time of yearning for something better and still

firmly connected with the truth of old. Snorrason sums up the situation well:

Christians had ... to seek refuge in confessional statements of Christian truth. This meant a valiant struggle against humanistic and rationalistic thoughts now tending to rejecting [sic.] the former conservative and evangelical conceptions. The tide of popular approval of these innovations caused an alternating movement of ebb and flow in spiritual life. This was what made up a fullness of time for the advent message to enter. Many longed for a religion that could satisfy the heart. Many felt the light of truth was departing from them, because the new theology filled them with perplexity and sorrow. They were thirsting for a knowledge of the living God, for some assurance of a life beyond the grave.

Into this framework and setting the first missionary of the Adventist Church started to preach his message.

\section{The Arrival of the Adventist Mission in Iceland}

I will now present a picture of the entry of the Adventist Mission into this above described context and try to sum up the main trends within the work of the church from what sources are available. No direct statement of aims and objectives of mission exists as it may not have been thought necessary to formulate such statements. But notices and comments gleaned from letters from the missionaries or short news-statements in church publications and reports at mission conferences or sessions or to higher church organizations give some indication of goals, objectives, and the progress of the work. Much information has been gathered from two papers written about the history of the Adventist church in Iceland, one by Björgvin Snorrason on the contribution of Östlund, to which I have referred already, and one on the work of the second missionary, O. J. Olsen

\footnotetext{
'Snorrason, "Pastor David Östlund and the Beginnings of the Seventh-day Adventist Church in Iceland," 6.
} 
from 1911-1933, by Guðni Kristjánsson. ' Also Steinpór Pórðarson’s dissertation mentioned above contains valuable information. These and other sources will frequently be referred to in this latter part of the chapter.

\section{David Östlund, the First Missionary In Iceland Expedient Message at an Appropriate Time}

David Östlund (1870-1931), who was introduced in the previous chapter as the first Adventist missionary in Iceland, arrived in November 1897 at a critical and decisive time in the nation's history. With the National Church still in a state of inertia it could be described as the time of calm before the storm, a storm which Östlund, as we have seen, was in a way instrumental in setting in motion. What Östlund had to contend with almost immediately in his work was a broadside attack against him on core issues of the Christian faith, arguments that in fact especially undermined belief in his very message, the three angels' messages of Rev 14, an attempt to overthrow belief in the infallibility of the Bible and the creation story. These attacks, based on rationalistic biblical criticism and evolutionary science, Östlund met ably and his contribution did not go unnoticed in Iceland as we will see later.

\section{Östlund's Mission Strategy}

Through a remarkable incidence during Östlund's voyage to Iceland where he unexpectedly met up with fellow believers who would support him in his work, we learn

\footnotetext{
${ }^{1}$ Guðni Kristjánsson, "Early History and Development of the Seventh-day Adventist Church in Iceland,"( Term paper, Andrews University School of Graduate Studies, 1977, which deals with the work of the second missionary in Iceland, O. J. Olsen, and the time period 1911-1933.
} 
something about his intended emphasis in his pioneering missionary effort. ${ }^{1}$ In a response to this divine intervention Östlund's discloses his initial aim: "Now I have friends and fellow believers as I come to Reykjavík. Now I have help to learn the language and perhaps also some help to circulate writings among those who speak Icelandic. If anything in the world is of the direction of God - then certainly this is it. It gives me boldness and strength to begin in faith."2 (Emphasis mine)

This in fact became characteristic of his strategy. Even during his voyage and immediately after his arrival Östlund set to work to learn the Icelandic language and he preached his first sermon in January 1898 , only five weeks after his arrival in a remarkably faultless Icelandic, and the people of Reykjavík came to hear him in great numbers. ${ }^{3}$ Second, publishing became a great and very effective tool in his hands and his first publication, a small book on the Sabbath which he wrote himself, ${ }^{4}$ was produced already in the fall of 1898 .

This first Adventist missionary is recognized as having forcefully opposed forces

'By what Östlund recognized as a supernatural intervention and confirmation of God's approval of his calling he happened to meet up with an Icelandic Adventist couple on board his ship to Iceland. This couple had emigrated to America some time earlier but had heard of the plan of the Nordic Union to send a missionary to Iceland. They then decided to sell their farm and travel to Iceland in order to be of assistance to the first missionary. Snorrason, "Pastor David Östlund and the Beginnings of the Seventh-day Adventist Church in Iceland,"10, quoting a letter by Östlund written in the Faroe Islands, November 21, 1897. The letter is quoted by L. Johnson, "Efterretninger fra Missionsmarken, Island," Trostermanden, January 1898, 27. Iceland," 10.

${ }^{2}$ Snorrason, "Pastor David Östlund and the Beginnings of the Seventh-day Adventist Church in

3"Pastor Östlund's outburst of activity in Iceland was met with greater following than any lecturer had yet enjoyed. His preaching appeared principally to be by lecture. Referring to his first sermon in Icelandic he said: 'But when the time for the commencement of the meeting had come I realized with sadness that my locality was far too small. It seated about 350 to 400 people, but about twice that number wanted to hear, so several hundreds had to return to their homes without being able to enter."' David Östlund, "Reykjavik, Island," Trostermanden, April 1898, 127, quoted in Snorrason, "Pastor David Östlund and the Beginnings of the Seventh-day Adventist Church in Iceland," 12.

${ }^{4}$ See reference to this publication in the previous chapter. 
that according to his conviction were destructive to Christianity in Iceland. And in his polemic he succeeded in gaining the public ear as he objectively and logically presented the Adventist doctrines firmly based on Scriptural evidence thus endorsing its full inspiration and authenticity. This was particularly evident during his debates with Rev. Jón Helgason (see above) and the ensuing controversy concerning Liberal Theology. Into that debate soon entered the question of Church and State relationship in connection with the Free Church discussion where Östlund supported his friend's Rev. Lárus Halldórsson's cause (see discussion on Rev. Halldórsson), both of them being "inspired by ideas of religious freedom."" Furthermore, Östlund was one of the "main antagonists to spiritualism in the country"2 as stated above.

During 1898, Östlund held public meetings in Reykjavík. He also visited the east coast, ${ }^{3}$ and he held meetings in Hafnarfjörður, a neighboring town to Reykjavik, but without converts reported. Every year Östlund ran public meetings in Reykjavík and in 1904 he is reported to having preached in the villages of Eyrarbakki and Stokkseyri, $70 \mathrm{~km}$ from Reykjavík. $^{4}$

\footnotetext{
l'“Östlund, in his magazine Frakorn voiced his criticism of the National Church in much the same manner as Rev. Halldórsson and many others had since the $1880 \mathrm{~s} . .$. The Adventists and the Lutheran Free-Church Movement, inspired by ideas of religious freedom, mobilized the people dissatisfied with the National Church." Pétursson, 153, 154. "Rev. Lárus [Halldórsson] involved himself quite extensively in the paper controversy between Jón Helgason and Östlund, since the Church and State issue was soon brought into the discussion." Gíslason, 34.

${ }^{2}$ Gíslason, 42 .

${ }^{3}$ Twice Östlund is reported to have visited the east coast of Iceland but there is no report of any converts even though his meetings were well attended. Snorrason, "Pastor David Östlund and the Beginnings of the Seventh-day Adventist Church in Iceland," 34, 35. ibid., 35 .

${ }^{4}$ David Östlund, "Reykjavík, Island," Evangeliets Sendebud, December 1904, 399, quoted in
} 
The Frakorn Magazine and Other Publishing Work

As suggested above Östlund demonstrated outstanding capabilities in his work. Right from the outset of his tenure there was an outburst of activity. His linguistic and oratory talents have been mentioned which quickly attracted the attention of the people of Reykjavík. But his achievements in the publishing work were no less outstanding. A skilled printer, he soon set up a printing press, of which for a time he shared ownership with Rev. Lárus Halldórsson. Here in 1900 Östlund started to publish his magazine Frakorn (Seeds). This paper was remarkable for its high editorial quality which soon secured it a wide circulation: "Frækorn, the magazine which David had begun to publish in 1900 was by . . 1905 by far the largest paper in Iceland. It was a whole library of information dealing with such items as religious and cultural matters, foreign and local news, health, temperance, stories for children, travelogues and even touching on economic problems. It was well-proportioned in its emphasis and vigorous and popularly written."1 Linguistically, an important issue at this time of growing national identity and interest for the purity of the Icelandic language, his style was impeccable: "Iceland's leading poet at this time, Matthías Jochumsson, ${ }^{2}$ with whom David corresponded, although they did not wholly agree on all religious matters, had this to say about David's flourishing monthly paper: "May God bless you for them [the "Frækorn" or "Seeds"] and pay you without measure. You are a remarkable sending. Nowhere can it be seen any more

\footnotetext{
${ }^{1}$ Snorrason, "Pastor David Östlund and the Beginnings of the Seventh-day Adventist Church in Iceland," 38.

${ }^{2}$ Rev. Matthías Jochumsson was a well-known Lutheran pastor and one of the greatest Icelandic poets. He has composed some of Iceland's best loved hymns even though he was critical of the Church at the time and not satisfied with the Lutheran Orthodoxy. David Östlund printed his poetry collection in his printing press.
} 
that a non-native has composed a single paragraph of the paper."1

The circulation of this magazine reached its peak in 1906 when it became a weekly paper with 4,450 copies printed and 4,000 subscribers. ${ }^{2}$ This continued until 1909.

Östlund was also publishing many books at this time (1905-1906), all in Icelandic.

Snorrason mentions eight titles by such authors as Ellen and James White, J. G. Matteson, A. F. Ballenger, E. J. Ahren, and also smaller works written by Östlund himself. ${ }^{3}$ The distribution of all of this literature was carried out by a dedicated colporteur, Niels Andersson, a Swede. The tremendous circulation of the Frakorn and other literature at this time was entirely due to the work of this man who "was in charge of the colporteur department being himself the only colporteur." ${ }^{\prime 4}$

By this time Östlund was also operating a school with three teachers ${ }^{5}$ and he had built a church, a project initially privately funded. ${ }^{6}$ This must be acknowledged as an outstanding achievement by Östlund and his coworkers, people working under difficult circumstances and financial strain.

${ }^{1}$ Matthías Jochumsson, Bréf Matthiasar Jochumssonar (Reykjavík: Bókadeild Menningarsjóðs, 1935), 643, quoted in Snorrason, "Pastor David Östlund and the Beginnings of the Seventh-day Adventist Church in Iceland," 38.

${ }^{2}$ Ibid., 36. Snorrason points out that the second largest publication at the time had 2,633 subscribers. The population of the country at this time was less than 80,000 with an average houshold-size of 5 to 6 people (see Pétursson, 17,60). This would seem to indicate that about a third of the population was receiving the magazine in their homes at this time.

$$
\begin{aligned}
& { }^{3} \text { Ibid., } 35 . \\
& { }^{4} \text { Ibid., } 38 . \\
& { }^{5} \text { Ibid., } 33 . \\
& { }^{6} \text { Ibid. }
\end{aligned}
$$




\section{Growth in Membership}

Through Östlund's impressive amount of work in lecturing, publishing and schoolwork which was, as we have seen, well appreciated by the public, he had established a church in 1906 in Reykjavík which by 1909 had 40 baptized members according to Union President J. C. Raft's report at the General Conference Session. In addition 14 Sabbath keepers met with that group on Sabbaths, comprising a group of 55 all together. Thirty-eight of these were baptized between 1905-1908, fourteen of whom were baptized in $1908 .{ }^{1}$ This indicates that growth which had been slow to start with had begun to materialize. Lack of growth the earlier years may have been partly caused by close contact with the Evangelical Lutheran Free Church as some people, awakened by Östlund's early preaching, may have joined that Church. $^{2}$

\section{Involvement of Lay Members in Missions Operations}

It is clear from the records that Östlund and Andersson carried the main load of leadership and the work of the mission in general. Still there is mention of very able lay people who were taking active part, even in public speaking. Then Östlund had engaged three very capable teachers for the school in 1906, probably from within the membership, who served there as long as the school operated. ${ }^{3}$ It thus seems clear that Östlund had local

'J. C. Raft, "Iceland," General Conference Bulletin, May 1909, p. 127, cited in Snorrason, "Pastor David Östlund and the Beginnings of the Seventh-day Adventist Church in Iceland," 40.

2"It is likely that many who had first attended the lectures of the Adventist missionary were among those who joined the Lutheran Free-Church congregation founded in the fall of 1899." Pétursson, 153.

3"'There were three teachers instructing at the school. They had all had prior experience in teaching. They were all well-qualified academically and had to their advantage taught in more than one subjectmatter area and more than one grade level." Snorrason, "Pastor David Östlund and the Beginnings of the Seventh-day Adventist Church in Iceland," 37. 
lay-involvement in mind and would without doubt have developed this further had his time of leadership not ended so untimely and abruptly.

\section{The Cultural Sensitivity of David Östlund's Approach}

What stands out when Östlund's early career in Iceland is studied is an approach characterized by striking inclusiveness and being attuned to existing society, not a compromise necessarily in terms of reduction in doctrinal or ethical standard, ${ }^{1}$ but in the sense of seeking to reach and serve the Icelandic society on its own terms and through its values and institutions. His approach and the basic attitude of his enterprise seem thus not to have been characterized by separatism and exclusiveness seeking to detach his converts from society. The latter approach would probably have been more what one could have expected considering his denominational background.

The above described outlook was evident in several ways in Östlund's work: First, his very rapid integration with Icelandic language and culture and the attitude exhibited in his lecturing which was described as "courteous and polite" while compelling. Second, his immediate engagement in the public debate in Reykjavik at his time of arrival where he showed concern and very soon an intimate knowledge of local affairs. Third, he had close relations with leading individuals within other Churches, such as Lárus Halldórsson of the

\footnotetext{
${ }^{1}$ Kristjánsson does state, citing an interview with O. J. Olsen, that Östlund's church practices were not completely in line with mainstream Adventism: "Östlund never conducted Sabbath School; his Sabbath observance was from six o'clock Friday to six o'clock Saturday; and he had not taught tithing, nor belief in Ellen G. White as a modern-day prophet." Kristjánsson, 9. Whether this had been Östlund's practice throughout his ministry in Iceland or a gradual development after his leadership had been rejected by the Union in 1909 is not entirely clear. Snorrason seems to favor the latter view. See Snorrason, "Pastor David Östlund and the Beginnings of the Seventh-day Adventist Church in Iceland," 66.
} 
Free-Church, ${ }^{1}$ Matthías Jochumsson and others. Fourth, and the prime example, was then his much loved magazine which must have required countless hours of work on his part. It served a plurality of purposes, assuming a role of a public service medium for general information and education of the whole of society rather than just attending to a purpose of soul-winning, or that of only edifying sympathizers or members. And, finally, he set up a school, as it seems, long before there was a need for such an institution for the children of Adventist believers, thus striving for the betterment of society in general.

Even though some could question whether in Christian witness it can be justified thus to prioritize the improvement of society within which it operates, it still is true that the spirit of isolationism has all too often characterized the mission endeavors of the Church.

\section{David Östlund's Downfall}

In spite of Östlund thus being a significant participant in the present exigent debate at the time as the defender of truth and the upholder of what was right, his sun was soon to set as he became involved in a financial scandal in 1909 and decided to evade legal prosecution and police involvement by fleeing the country for America. After having been cleared of debt by the Nordic Union, he was desirous of taking on the leadership of the church in Iceland again but this was turned down by the Union. Östlund, then still in America and entirely frustrated by the state of affairs, displayed a near inconceivable lack of judgment and spirit of defiance as he, in great doubt as to what to do, but contrary to his earlier insistent warnings based on Scripture, decided to consult a spiritualistic medium in

\footnotetext{
${ }^{1}$ Some cooperation and contact was also between these two men and the leaders of the
} Salvation Army as they regularly assembled for a joint prayer group at each other's headquarters. Gíslason, 29. 
America. Consequently Östlund moved back to Iceland, but after controversy with the Nordic Union leadership that even became public in the leading newspaper in Reykjavík, he was replaced in 1911 as the leader of the Adventist cause in Iceland by pastor O. J. Olsen from Norway.

\section{Östlund's Contribution, a Summary}

In spite of the very unfortunate turn of events at the close of Östlund's tenure, one's view of him and his work must not be colored only by this and thus lose sight of what in fact was an outstanding achievement. His contribution was an answer to a very present need in Icelandic society and an impressive start of the work of the Adventist mission in Iceland. His work in Iceland, certainly prompted by God, was initiated at a crucial time when the country was, as often has been pointed out, in a state of social turmoil, spiritual dearth and privation, when the light of the Word of God was fast departing as the nation was being engulfed in the darkness of Liberal Theology, spiritualism and secularism. Östlund's ability to emphasize the singularly important aspects of the contribution of Adventism in this context - the authority and relevance of the Bible and faith in God as the Creator and Sustainer of all - was certainly a provision of God at a crucial time. And by the grace of God Östlund was able to present this truth in a way that was recognized, respected and appreciated by nearly all who heard him.

Even the attack of evil powers at the very end of his time of service did not eclipse what had been thus established and Elder Raft's statement at the General Conference session in 1909, which he certainly would not have issued had he known what lay in wait just around the corner in Iceland, still became a most appropriate evaluation of what had passed and what lay ahead: "Now that the foundation has been laid, we may be justified in 
expecting still greater advancement." To that greater advancement we will now turn.

\section{Olaf Johan Olsen, the Second Missionary in Iceland \\ In the Shadow of David Östlund}

In some ways one can speak of a fresh start of the Adventist Church in Iceland at the arrival in August 1911 of the Norwegian missionary Olaf Johan Olsen (1887-1978), Östlund's replacement. What had looked as a very promising start of the mission work of Östlund ended in an unfortunate way as most of what he had built throughout his tenure seemed in 1910 to have been dismantled. Only about half a year after Elder Raft's report at the General Conference in May 1909, referred to above, where he reported favorably on growth and prosperity of a church in Iceland of 40 members and 15 in addition who were keeping the Sabbath, we find the missionary in Iceland dismissed due to financial fraudulence, the flourishing church paper discontinued, the church building burnt to the ground (January 22, 1910), and the church membership in disarray. ${ }^{2}$

Not willing to step down when the Union intended to replace him with another representative, Östlund took the initiative in making the whole controversy public in the Reykjavík newspapers (he printed the main newspaper in his own printing shop at that time) and a "paper war" raged for some time between him and Olsen in which Union representatives also took part, much to the dismay and embarrassment of the church members and other sympathizers of the cause.

After some delay Olsen was granted the Royal Commission as the authorized

'Raft, "Iceland," quoted in ibid., 48.

${ }^{2}$ Snorrason gives a detailed account of this extraordinary turn of events leading to the replacement of Östlund by Olsen. Ibid., 43-67. 
leader of the Adventist church in Iceland in the summer of 1912 but the "war" between the two leaders was still not over. Of the 40 baptized church members, 23 had in fact already separated themselves from Östlund's church in 1910 when his business blunder and his dispute with the Nordic Union had become clear to them. ${ }^{1}$ These people voted Olsen as their leader on his arrival. The remaining membership still supported Östlund and for three years, 1911-1914, two Seventh-day Adventist churches existed in Reykjavík.

Both of them placed their sickle to the harvest. Mr. Oestlund found no following. His audience decreased to nil. This did neither, however, upset the structure nor the growth of the true Seventh-day Adventist Church in Iceland. Although Mr. Oestlund more or less preached on the same topics as Pastor Olsen, and had the advantage of knowing Icelandic thoroughly and being an experienced orator, his hall of preaching quickly became empty and remained so. . . During these same three years from 1911 to 1914 the hall in which Pastor Olsen preached was always full to the utmost. ${ }^{2}$

\section{O. J. Olsen's Mission Strategy and Cultural Sensitivity}

Olaf Olsen, only twenty-four years of age on his arrival in Iceland with his then pregnant wife Alina, set immediately to work in spite of the difficult circumstances I have briefly described. It was obvious from the start that Olsen had bold plans in mind for his mission project in spite of his youth and inexperience. Already in the summer of 1911 he laid plans with the Union representative for the immediate rebuilding of the church, Betel (the new Betel stood ready in the beginning of 1912), and plans were made to revive the colporteur work (a considerable stock of several titles that Östlund had printed had been destroyed in the church fire of 1910). Olsen hoped to have the book Christ Our Savior by Ellen G. White translated and published. (The book was ready in the fall of 1912.)

\footnotetext{
'Kristjánsson, 6. A few more seem to have joined Olsen's church later as the Church records include names of 35 baptized by Östlund.

${ }^{2}$ Ibid., 65, 66.
} 
Olsen was also determined from the beginning to identify himself fully with the Icelandic people and learn their language quickly. Knowledge of the German language helped him with the Icelandic grammar, and pronunciation he found easiest to learn from the children. With regard to his preaching he decided never to speak through a translator: "From the beginning [Olsen] insisted on being an Icelander, never preaching through a translator. While learning the language, he asked a lady in the church ... to sit on the front row and write down his mistakes. When the meeting was over they compared notes, and progress was made."1

These elements became pillars in Olsen's strategy to conquer Iceland with and for the gospel. First, he wanted to develop a strong colporteur ministry and to spread Adventist literature far and wide in order to prepare and open up interest among the people in the message. He also realized the impossibility of orally reaching the population of 85,000 spread out in small communities and in farming areas around the 103,000 square $\mathrm{km}$ island where roads were nearly nonexistent. Here the printed page must be the first way of advance. ${ }^{2}$ Second, he would then run public meetings in selected areas, and very often churches were formed as a result. This program he extended to many areas of the country and became quite successful in forming groups of believers and raising up churches in many different parts.

Olsen became an outstanding speaker who during his lectures presented even the most complex issues without notes, even quoting at length from the Bible from memory.

\footnotetext{
${ }^{\text {l} K r i s t j a ́ n s s o n, ~ 11 . ~ K r i s t j a ́ n s s o n ~ a l s o ~ r e l a t e s ~ t h a t ~ i n ~} 1914$ an article appeared in Vísir, a daily newspaper in Reykjavík in which Olsen was praised personally for credibility, friendliness, respectability and intelligence and for having learned the Icelandic tongue. Vísir, 20 August 1914, quoted in ibid., 27.

“"Beretninger fra O. J. Olsen ved Unions mödet i sommer," Evangeliets Sendebud, 9 September 1914,540 , quoted in ibid.
} 
This impressed his listeners who were not used to this form of delivery from their State Church pastors. Olsen's type of presentation was a typical Adventist prophetic preaching approach, where he interpreted current events in the light of biblical prophecy, an approach to religion that Icelanders had never encountered before. ${ }^{1}$ This contributed to the general popularity of Olsen's meetings and the halls where he preached were usually filled every night.

But in addition to these factors we find much of the secret to Olsen's success in his ready identification with the people whom he worked for, and the care and concern he showed in his association with them. In two separate incidences Olsen is reported to have postponed his campaign due to epidemics where he instead organized a public health effort to assist the health authorities. The first time this happened was in Hafnarfjörður in the fall of 1918 when a influenza epidemic caused the death of hundreds of people and whole families became bedridden. Olsen was due to start a series of meetings there but instead offered his help to the people. Kristjánsson tells the story: "In Hafnarfjörður, Olsen's volunteered help was welcome. He visited rich and poor alike, caring for their medical needs. Olsen suggested that a town meeting be held to discuss the situation. Teams were organized to collect money in order to purchase food for needy families.... Many people reevaluated their opinion of Adventism as they witnessed Olsen's unselfish attitude. Thus, in December when it was considered safe to start the evangelistic meetings, Olsen had a full house."2

The second incidence happened during a typhoid epidemic in the Vestmannaeyjar,

\footnotetext{
${ }^{1}$ Reynir Guðsteinsson, “Aðventistasöfnuðurinn í Vestmannaeyjum 40 ára,” Blik, 1965, 87, quoted in ibid., 48.

${ }^{2}$ Kristjánsson, 34.
} 
an island off the south coast of Iceland, in the spring of 1923. Olsen had been running a campaign in the town but before the close of the series the epidemic broke out and all public gatherings were prohibited by the authorities. People in the town were struck with terror and no one wanted to touch the sick people for fear of catching the disease. Olsen, Katy Henriksen, a hydrotherapist from Denmark who had come to start a clinic in Vestmannaeyjar in conjunction with Olsen's effort, and some other associates of Olsen then volunteered to help. "With permission from the medical authorities [they] went from house to house and carried the sick people to the temperance hall. There they where isolated and taken care of by other volunteers. By mid-summer 1923, the disease was under control. For this courageous, self sacrificing work, Olsen, Henriksen, and their fellow-believers were praised and respected throughout the community."1

Apart from being an indication of the zeal and determination with which Olsen and his co-workers carried out their mission work, these incidents became a powerful testimony to the general public that here was a group of Christians who cared for the community they lived in. They were not only interested in securing converts for their church, but were ready to let action speak when the need arose.

\section{The Flourishing Publishing Work}

Olsen, as we have seen, placed emphasis on the publishing ministry right from the start. In this area he leaned heavily on the experience of Niels Andersson who had worked in this field with Östlund since $1903 .{ }^{2}$ It is safe to say that Andersson, who had traveled the country extensively and possessed first-hand, practical knowledge about the people,

\footnotetext{
${ }^{1}$ Ibid., 49.
}

${ }^{2}$ SDA Encyclopedia, 1975 ed., s.v. "Iceland." 
their conditions and preferences, was Olsen's key to success in this work.

Andersson was confident and optimistic from the start and suggested an edition of 3,000 copies for the first book, Christ Our Savior.' Olsen was reluctant at first. He wanted to go for 2,000 copies, but after listening to Andersson he settled for 2,500 copies. ${ }^{2}$ The book was ready in the fall of 1912 with the Icelandic title Kristur frelsari vor, and was very favorably received. Andersson reports to have sold a book in every house in Reykjavik, often more than one. ${ }^{3}$ The new team was off to a good start and the prospects were promising.

But Olsen and Andersson were not satisfied with the present state of affairs. The success convinced them that the colporteur work must be expanded and they ventured to entrust this ministry into the hands of local members, reluctantly at first. Björn Sumarliði Jónsson, a fisherman by trade who had been baptized by Östlund in 1908 , was the first one they tried. "For three days Andersson went with him to orient him to his new work. On the third day, which was a Sabbath, Jónsson was colporteuring by himself after sunset. The first hour he sold twelve books, the following two days, fifty books, and in forty days, he had sold 800 books." $^{4}$

This successful experiment led the men to enter into a colporteur training program for which Andersson was responsible. Another Icelander, Einar Sigurðsson, was engaged

\footnotetext{
${ }^{1}$ This book was originally produced in 1896 by Edson White as an easy-to-read story of the life of Jesus (156 pages) by adapting material from The Desire of Ages by his mother, Ellen G. White. The book was amplified in 1900 to 182 pages. It was published in Norwegian in 1910 under the title Kristus vor frelser. 21.

${ }^{2}$ N. Andersson, "Fra Island," Missionsefterretninger, January 1913, 3, quoted in Kristjánsson,

${ }^{3}$ N. Andersson, "Fra Island," Missionsefterretninger, July 1913, 50, quoted in ibid., 22.

4،"Beretning fra O. J. Olsen," Evangeliets Sendebud, September 1914, 540, quoted in ibid..
} 
in the work and the three men sold out the entire edition of 2,500 books in four months in Reykjavík alone. Based on this success another 4,500 copies were ordered for use in the rest of the country. ${ }^{1}$

The next summer (1913) a systematic coverage of the country was begun by the team of colporteurs and, in 1914, after a third edition of Kristur frelsari vor had been printed (3,000 copies), a total of 10,000 copies of the book had been sold to the about 85,000 inhabitants of Iceland. Close to every household in Iceland had by now access to this book with its simple but powerful message about the fundamental truth of Christianity, the story of Jesus. ${ }^{2}$

Already in 1914 another book was being prepared and was ready in the fall with 8,000 copies. This number reflects obviously the spirit of optimism that the tremendous success with the first book had generated and evidently Andersson's enthusiasm had enticed Olsen into this record-breaking venture. However world events would interfere here in remote Iceland, as World War I broke out. No actual warfare took place in Iceland but the economic impact was felt there. "Under normal conditions, I would never have dared hope for more than one thousand orders in Reykjavik and Hafnarfjörður; and when the war dragged on, and unemployment became widespread, my courage started to go

$$
{ }^{1} \text { Ibid., } 23 .
$$

${ }^{2}$ Ibid., 27. Kristjánsson refers to minutes of the first Mission Conference in Iceland in 1914 where Olsen reports that colporteurs had visited nearly every home in the country with the new book (minutes from meeting of August 18). It is significant that Olsen and his associates chose to introduce Adventism in the country at this time by this publication which deals with such a central and fundamental truth of Christianity on which most Christians would agree. This book presents a clear, non-controversial message about Jesus Christ, a welcome expression of the heart religion which was being obscured at the time due to developments on the national religious scene to which I have alluded earlier, the loss of which was mourned by many. This may to a degree explain the tremendous sales of this book. A publication dealing with such topics as the Sabbath or prophetic issues might not have struck a cord with the nation in the same way at this stage. These issues were dealt with in the second book Tákn tímanna (A Look at Our Times). 
downhill. Even N. Andersson predicted difficulty in selling the 8,000 copies printed."'

But the colporteurs began their work in faith and immediately there was success.

Within Reykjavík one of them sold 200 books in one week. Their courage was boosted and again the whole country was visited by these faithful men. Next summer a second edition had to be produced making the total copies printed close to 10,000 . This book (Tákn tímanna) contained an analysis of current world events in the light of biblical prophecy. ${ }^{2}$ What could be more relevant at this time than affirming the certainty of God's leading hand in world events and proclaiming the assurance of his victory at last? At the same time core elements of the Adventist message were introduced to a sizeable portion of the population.

In the period 1918-1922, a post-war economic recession affected the sales of books. ${ }^{3}$ In the meantime Andersson left the country after many years of outstanding pioneer work. With his departure an era in the history of the Adventist church in Iceland came to a close. The tremendous effort of this faithful man, mostly working behind the scene, had meant much in the early groundbreaking phase of the church in Iceland. As we have seen, he was an important driving force behind Östlund's success in his publishing work, not the least with regard to the magazine Frakorn which reached by far the greatest distribution of any publication in the country at the time. The singularity of this

\footnotetext{
'O. J. Olsen, "Island," Missionsefterretninger, April 1915, quoted in ibid., 28.
}

${ }^{2}$ The original title of the book in Danish was Et blik paa vor tid, 1. bind (A Look at Our Time, vol. l), and was authored by Erik Arnesen, a Misson School principal and the secretary of the Nordic Union. The Icelandic titled was Tákn tímanna, or Signs of the Times.

${ }^{3}$ In this period only two books were produced, Lifsferill pjóðanna (The Rise and Fall of Nations) by Arnesen (1918) and Sigur karleikans (The Marked Bible) by Charles L. Taylor (1922). But the books Deilan Mikla and Vegurinn til Krists (Great Controversy and Steps to Christ) by Ellen G. White and Profsteinn aldanna (The Touchstone of the Ages) were also acquired from the Icelandic-speaking church in Canada in exchange for the book Sigur karleikans, which was not selling much in Iceland. 
achievement in a country sparsely populated, mountainous and near roadless we may only faintly begin to appreciate today. Andersson's role as a source of inspiration, support, and information to Olsen in his initial difficult period was decisive for the latter's early success. At the end of his service Andersson is reported to have conducted an evangelistic campaign by himself in Akranes in the west of the country. This may not have been a unique incident even though no records exist to indicate otherwise.

During the very difficult period for the colporteurs after the war some evangelistic magazines were produced such as Tákn tímanna (Signs of the Times) and Ljósvakinn (Rays of Light) and the same strategy was used as before, to conduct evangelistic campaigns in areas that had been saturated with literature. This was the case for instance in Vestmannaeyjar in 1921 where a colporteur (Guðmundur Pálsson) was surprised to find great interest and where he sold a large amount of Tákn tímanna. This inspired Olsen a year later to conduct meetings in that place where he encountered one of his greatest successes throughout his entire career in Iceland (see below).

In 1924 the sale of books started to pick up again and in 1928 two books were produced, ${ }^{1}$ both of which were published with about 10,000 copies.

\section{Systematic Evangelism}

Olsen very quickly became a popular and effective evangelist as noted above. From 1912 he conducted public meetings in Reykjavík which nearly immediately produced results in members baptized. During the first Mission Conference held in August 1914 the Union president, Elder J. C. Raft, reported optimistically: "Now we have

${ }^{1}$ These books were Pattir ür dagbók lifsins (Lifes of Great Men) and Frá raðustóli nátturunnar (Thoughts from the Mount of Blessing) by Ellen G. White. 
fifty members, about 9,000 copies of Kristur frelsari vor have been sold, thousands of tracts have been sold and plans are being laid for the printing of 8,000 copies of a new book."1

Though Olsen confined his work to Reykjavík during the first few years it soon became clear that he would not remain satisfied there for long. In 1914 he started work in Hafnarfjörður, a town fifteen km southwest of Reykjavík, establishing his first church there a year later. By then Pétur Sigurðsson ${ }^{2}$ had joined Olsen as a licenced minister for the church. Olsen left him in charge of the Reykjavík church and to run a campaign there while he himself set up residence in Hafnarfjörður. Olsen also ventured further west, running meetings in Keflavík and Garður fifty km southwest of Hafnarfjörður.

In the fall of 1916 new territory was again entered as Sigurðsson was assigned to work further afield, in Eyrarbakki, sixty km southeast of Reykjavík. In the spring of 1917 Sigurðsson reports nine people ready for baptism after his campaign there whom Olsen then baptized on May 13. A congregation could then be organized of seventeen or eighteen members in this place, the surplus number presumably being accounted for by members living in the area from before (even from the time of Östlund) and the evangelist's family. ${ }^{3}$ Sigurðsson was directed to continue in the same place for another year but, then, in the fall of 1918 new field was again broken as he and his wife and their three-month-old baby were sent to Ísafjörður on the west coast, $500 \mathrm{~km}$ northwest of

\footnotetext{
${ }^{1}$ Icelandic Mission, Minutes of Meetings of the Mission Committee, 1914-1933, meeting of 18 August 1914, quoted in ibid., 26.

${ }^{2}$ Pétur Sigurðsson was converted in Norway and came to Iceland in 1914 and served as a licenced minister and evangelist. In 1920 he left for Canada to work for the Adventists among the Icelandic settlers in Winnipeg.

${ }^{3}$ P. Sigurðsson, "Fra Island," Missionsefterretninger, June 1917, 42, quoted in ibid., 32.
} 
Reykjavík. ' Sigurðsson's work in Ísafjörður and the neighboring towns (Hnífsdalur and Bolungarvík) became successful and before he left in 1920 he had established a church in Bolungarvík of twnety-two belivers. ${ }^{2}$ During this same time Andersson and his new wife had been working in Akranes, seventy km north-west of Reykjavík, as already mentioned, where a few members joined the church.

In 1921 Guðmundur Pálsson, ${ }^{3}$ a colporteur who turned to ministerial work, stayed in Ísafjörður for a few months and followed up on Sigurðsson's interests. Olsen joined him and they encountered an outstanding interest among the people of the area. Olsen reports: "In this area the people are seeking the truth, more than any place I have previously witnessed. A storekeeper expressed to me his amazement, saying that in his estimation, half of the population in the area were very interested in the Adventist teaching. It worried him that soon it might become difficult to hire a worker on Saturdays." 4

Pálsson relates a similar experience: "Where I have been on the west coast during the winter, I have seen interest developing like never before." Clearly the population there was receptive at this time in an extraordinary way.

This discovery of remarkable receptivity and interest in the message was not to be

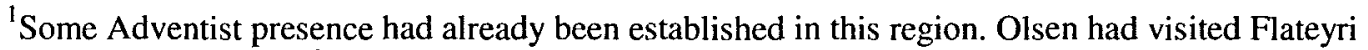
in Önundarfjörður (20 km from Ísafjörður) already in 1913 and baptized a few people who had been introduced to the message through Adventist connections in Denmark.

${ }^{2}$ P. Sigurðsson, "Bolungarvík," Missionsefterretninger, May 1920, 60, quoted in ibid., 39.

${ }^{3}$ Guðmundur Pálsson was baptized into the Hafnarfjörður Church in 1915 . He soon became engaged in the colporteur work and later in pastoral work and evangelism as a licensed minister and served faithfully for many years.

${ }^{4}$ O. J. Olsen, "Island," Missionsefterretninger, June 1921, 57, quoted in ibid., 40.

${ }^{5}$ G. Pálsson, "Fra Island," Missionsefterretninger, August 1921, 77, quoted in ibid. 
a local occurrence but rather a foretaste of even greater things to come in evangelism.

\section{The Close of a Time of Sowing}

In a way one can speak of an end of the initial phase in Olsen's mission period in Iceland and the beginning of another around the year 1922-an end of the time of sowing, which in reality began with the arrival of Östlund-and the beginning of a time of reaping. As we have seen Olsen started his work by intensifying the colporteur work significantly, a venture leading to the outstanding results of about 33,000 copies of different books and thousands of evangelistic papers sold and tracts distributed to the Icelandic population of about 90,000 and nearly every home visited at least once. ${ }^{1}$ Unfortunately, due to the effects of the depression, the sale of literature had in 1923 almost come to a standstill. ${ }^{2}$ Public meetings had been conducted in Reykjavík and its neighboring towns within a radius of about sixty-seventy $\mathrm{km}$. Also there had been the campaign by Sigurðsson on the west coast as the interest there, which had been generated from abroad, called for immediate attention. Through this work 190 had been added to the church in this period. The additional 35 members from the time of Östlund who had joined Oslen's church made in all 225 acquisitions from the beginning (excluding those of Östlund's followers who did not continue with Olsen). Three churches had been established in addition to the one in Reykjavik. Certainly all this was a remarkable achievement, but in fact yet greater things loomed ahead. The time of sowing was now coming to a close in which Niels Andersson had taken such an outstanding part. Ahead

'O. J. Olsen, Minutes, meeting 16 May 1924, quoted in ibid., 51.

${ }^{2}$ The colporteur work had practically come to a complete halt. Occasionally one or two colporteurs went out, but sales were very small. W. E. Read, "Island," Missionsefterretninger, February 1924, 13, quoted in ibid., 52. 
was a time of reaping of souls for God's kingdom.

\section{A Time of Reaping}

The following period saw explosive growth to begin with, but soon conditions changed, and towards the end of Olsen's active period in Iceland in the thirties there was a time of dwindling growth.

\section{Vestmannaeyjar 1922-26}

Olsen's experience in the Vestmanneyjar from 1922 to 1924 was one of the highpoints in his time of service in Iceland. Vestmannaeyjar was at this time a very rapidly growing fishing town with a population of $2,600 .{ }^{1}$ Much of its population originated from the nearby farming community in the south of Iceland ${ }^{2}$ who moved to the islands in search of work. During the fishing seasons there was an influx of workers from many places in Iceland, even Faroese sailors who from the Faroes as the Faroese regularly engaged in fishing along the Icelandic east coast.

In the year before Olsen's arrival, Vestmannaeyjar were visited by a Norwegian Pentecostal missionary, Erik Åsbø, who, on behalf of a Swedish Pentecostal congregation, had carried out missionary work in Iceland (Reykjavík) since 1920 but without any significant results. In Vestmannaeyjar, however, he succeeded, in spite of strong resistance from many in the community, to gain results as sixty people in the

${ }^{1}$ From 1910 to 1920 the population of Vestmannaeyjar grew from 1,329 to 2,426 , or by $45.6 \%$. The next decade the growth rate was $28.5 \%$ while from 1930 to 1950 it fell to $4.5 \%$. Statistical Yearbook of Iceland (Reykjavík: Statistical Bureau of Iceland, 1998), CD-Rom.

${ }^{2}$ Pétur Pétursson, "Religiösa minoriteter på Island,” Kykohistorisk Aarsskrift, vol. (1989): 153. Pétursson points out that according to communion attendance records from the time it is clear that the people of the rural southern districts of Iceland were some of the most faithful in support of the church and some of the least affected by the secularization influences that had started in Iceland in the 1880s. 
summer of 1921, particularly women, the wives and daughters of the fishermen, had shown interest in his message, or in his own words: "bore witness that they had experienced salvation in the biood of Christ and wished to follow Him and honor God." At Åsbø’s meetings faithhealings were attempted, which attracted a great deal of attention and agitation. There was commotion at his meetings and he and his assistants felt they were persecuted, and even feared there might be violence. Due to this his public meetings were discontinued for a time. ${ }^{2}$

In the wake of these events Olsen arrived in Vestmannaeyjar in November 1922 and advertized meetings that were extraordinarily well received. ${ }^{3}$ His campaign continued till the following spring, filling the largest hall in town at every meeting, until he was forced to stop due to the outbreak of typhoid fever (see above). Olsen visited those interested in his message in their homes and by March 1923 Olsen reports to have requests from one hundred families for visits. "[This is] the hardest work I have ever done. To visit with ten or fifteen families every day, study the Bible with them, and

'Erik Åsbø, Evangelii Harold, 6 October 1921, quoted by Pétur Pétursson, "Revivalism and Lay Religions Movements on Iceland: A Survey and Account of the Current State of Research," Scandinavian Journal of History 11 (1986): 342. This was the time of the arrival in Vestmannaeyjar of the Adventist colporteur, Pálsson, who sold a large amount of the Tákn timanna magazine (see above).

${ }^{2}$ lbid. The antagonism to Åsbø's activity seems to have come to a head during the spring and summer of 1922, just months before the arrival of the Adventist representative.

${ }^{3}$ Olsen, aware of Åsbø's experience, sought to avoid the pitfalls he had encountered in Vestmannaeyjar. The story is told that when Olsen arrived at the first meeting he found every seat taken but noticed that the men on the front row all sat with their hats on. Olsen realized that these were the troublemakers who had caused $\AA$ sbø much distress by showing him contempt in this way. Recognizing that a mistake at this first meeting could mean the loss of Vestmannaeyjar he quietly asked the Lord to somehow remove those hats but keep the congregation calm as well. At the set time to start the meeting Olsen rose and announced the opening hymn - one of the old Icelandic passion hymns-"Son Guðs ertu með sanni." Two songs every Icelander with respect for himself is obliged to sing reverently, standing, and with his hat off, this one and the national anthem. This Olsen knew and as he started to sing with his strong baritone voice "every hat came off . . . and the people listened intently during the meeting," O. J. Olsen, interview, May 1976, Kristjánsson, 46. 
answer their many questions, is serious business, and demands much physical endurance. ${ }^{1}$

Olsen wished it to be recognized that he was planning on a long-term Adventist presence in Vestmannaeyjar and they were there in order to be of help to the community and by January 1923, on his initiative, a hydrotherapist, a Danish lady, had come and set up a clinic. Olsen also moved his residence to the island in the beginning of 1923 and, he being a skilled carpenter, embarked on the construction of a house intended as living quarters for himself and his family, as a meeting house for the yet unbaptized believers, and a facility for the clinic. The house was completed in the fall of 1923 and became known as "Baðhúsið," (the "bath-house.") ${ }^{2}$

Through these and other initiatives Olsen is recognized for having sought to improve the general standard of life in Vestmannaeyjar. The hydrotherapy clinic, which remained in operation for decades and was primarily intended as a therapeutic institution, also set in motion a badly needed reform in hygienic standards in the community. Through his building projects Olsen introduced building techniques previously unknown to the islanders, and even in the unrelated field of vegetable growing he is credited for having been an innovator in the community. ${ }^{3}$ But Olsen made the greatest impression on the people by his manner of presenting his message as he in a striking way interpreted historic events in the light of biblical prophecy, a connection unheard of by the islanders. It would be reasonable to suppose that the recent World War was fresh in people's minds 47.

'O. J. Olsen, "Vestmannoerne, Island," Missionsefterretninger, May 1923, 45, quoted in ibid.,

${ }^{2}$ R. Guðsteinsson, “Aðventista söfnuðurinn î Vestmannaeyjum 40 ára,” 87, quoted in ibid.

${ }^{3}$ Óskar Gíslason, interview 1987, quoted in Pétur Pétursson, Från väckelse til samfund-Svensk pingstmission i öerna $i$ Nordatlanten (Lund, Bibliotheca Historico-Ecclesiastica Lundensis 22: Lund University Press, 1990), 69. 
and that its terrors and the subsequent depression lent force to Olsen's arguments.'

The first baptism in Vestmanneyjar of twenty-seven people took place on 26

January 1924; next Sabbath three more were added and a church was established with thirty members. The next three years seven more baptisms were conducted so by the end of 1927 the church had doubled its membership. ${ }^{2}$ In 1925 the members built, entirely by their own means and under Olsen's leadership, a church building seating 175 people and in 1928 a church school was opened. ${ }^{3}$

\section{Reasons for Success in Vestmannaeyjar}

The sudden success of the Pentecostal mission in Vestmannaeyjar in the 1920s is remarkable seeing that such a reaction to a religious proclamation was very atypical in Iceland. Pétursson goes as far as to call it the first and most significant religious revival to take place in Iceland. ${ }^{4}$

It is necessary to analyze this sudden growth in the Pentecostal mission in Vestmannaeyjar as it may shed light on religious life in the rapidly growing seaside towns and villages in general at the time and may help to explain the success of Adventist activity in these towns, a success, however, that was short lived in many places

\footnotetext{
'Kristjánsson, 48. He points out that the believers in Vestmannaeyjar deny the idea of a crisisoriented conversion to Adventism.

${ }^{2}$ By October 1927 the Vestmanneyjar church had 62 members, 22 men and 40 women. By comparison among Aasbö's first baptized members ( 19 February 1924, 19 candidates and 2 a week later, 21 in all), 19 were women and 2 men.

${ }^{3} \mathrm{~A}$ building was added later in order to extend the school. In 1941 the school was reported to have 83 pupils and two full-time teachers. Július Gưmundsson, Minnigarpattir ür starf Aðventsafnaðarins á Íslandi (Reykjavík: Frækornið, 1994), 22.

${ }^{4}$ Pétur Pétursson, "Revivalism and Lay Religious Movements on Iceland: A Survey and an Account of the Current State of Reserarch," Scandinavian Journal of History, 11 (19XX): 342.
} 
due to rapid change in the socio-economic conditions.

Pétursson seeks to explain this occurrence in sociological terms, and he sees a plausible rationale for the success of the Pentecostal mission in applying the deprivation theory described by Glock and Stark who in their work speak of organizational, social, ethical and spiritual deprivation. ${ }^{1}$ In short it is Pétursson's theory that there existed organizational, spiritual and social deprivation among the wives of the fishermen in Vestmannaeyjar at the time that could not be relieved by the existing institutions or organizations of society. Péturson describes a development of urbanization (see discussion above) affecting the social and religious structure of people's lives as not only certain pillars of spiritual and social life ${ }^{2}$ dwindled and disappeared, but also the traditional structure of domestic life was altered extensively. ${ }^{3}$

Pétursson further describes how the new middle class that was rapidly forming in the urban centers did nothing to alleviate this situation. In fact the clergy who in the rural areas had lived and worked alongside the population as a farmer among farmers, albeit in a leading role, as most of them operated a farm along with their pastoral duties, now

${ }^{1}$ Pétursson, "Religiösa minoriteter på Island," 149-156. He refers to the work of Charles Y. Glock and Rodney Stark, Religion and Society in Tension (Chicago, IL: Rand McNally, 1965).

${ }^{2}$ Such as the very important evening worships on the farms where the Bible and collections of sermons were read, hymns were sung and prayers said.

"It was now no longer the case that farm workers shared the house with the farmer and his family; the farmer was no longer the undisputed central figure of a household that in turn worked as a closely knit unit at production and was the foundation to people's livelihood. The husband, the son or the brother, or all of them, were now engaged in earning a living on some small fishing boat out on the perilous sea. Thus there did no longer appear to be in the same way a head of household embodying the security and orderliness of life in a dual sense as the master of daily affairs and as the one responsible to administer God's word on behalf of both the family and the household as a whole. Now the women were "home alone" both spiritually and temporally speaking. The women had lost their connection with the traditional form of religion and church life. But they had received a Christian upbringing and had been indoctrinated in a religious outlook on life which they now could not harmonize with present social reality. This situation gave rise to a spiritual deprivation which could not be alleviated by the existing social or political structures or institutions." Pétursson, "Religiösa minoriteter på Island," 153 [my translation]. 
belonged to the urbanized middle class, a segment in society more distant from the commion people. Thus the established church itself was unable to meet the spiritual needs of to these women as it was wholly inadequate in offering them and the workers sufficient religious nurture outside the regular Sunday services. In the church's program there existed no women's, youth, or mission society and the church operated no house-call service. It still performed in the same way as in the old rural context where the farms themselves had provided the setting for personal spirituality and nurture:

Here in the town setting the clergyman was a civil servant who represented to the women a world altogether different from their own. The complete lack of a lay oriented program on behalf of the church confirmed a gulf between the spiritual needs of the fishing population and the established church. The women had to seek relief for their spiritual needs of security and fellowship somewhere else... Their spiritual and emotional deprivation could in no way be relieved within the established religious structure. $^{1}$

In Pétursson's opinion the Pentecostal revival (1921) then filled this present void as it offered religious fellowship and kerygma that appealed directly to the situation and needs of these women.

The success of the Adventist mission endeavor in the form of the canvassing work of Pálsson (1921) and the subsequent campaign of Olsen (1922-1924) may have enjoyed favorable conditions in Vestmannaeyjar on similar grounds as the Pentecostal movement. Furthermore, it seems plausible that similar dynamics were operational in other places along the Icelandic coast in the west, north, and east where fishing villages were very rapidly growing. This could then account for the ready acceptance of religious literature and interest in lectures about religious matters at the time and, further, may also account for the rather short-lived receptivity of these centers of population as conditions changed.

\footnotetext{
${ }^{\mathrm{I}}$ Ibid., (my translation).
} 


\section{Reykjavík 1925-1927}

While Olsen resided in Vestmannaeyjar from 1923 to 1926 very little progress was made in Reykjavík.' The church there of about 150 members suffered from inadequate housing facilities for their activities and already in 1921 plans had been made to erect a church building to accommodate the activities of the church ${ }^{2}$ at that time and which should stand ready in 1923. To accomplish this financially, numerous measures were suggested. Apart from the sale of the present building the church building, Salem, in Hafnarfjörður, was to be sold. ${ }^{3}$ But these plans were delayed until 1925 due to post-war economic difficulties. The church building, situated near the center of Reykjavík with a seating capacity of 275 people (and an overflow hall with space for another 100) was dedicated on January 24,1926 with 1,000 people present. ${ }^{4}$

At the time of the completion of the church new life was infused into the Reykjavík church, partly due to the relief from physical restraints and also as Olsen now moved back to the capital from Vestmannaeyjar. As soon as the church was dedicated he launched evangelistic meetings there with a full house every night. Already in May there was a baptism of 20 people and during the remainder of that year and the next an

${ }^{1}$ According to the Conference records the number of members with an address in Reykjavik who were baptized during 1920-1925 are as follows: 1920, 19; 1921 and 1922, 12 each year; in 1923, 1; 1924, 5 , and in 1925, 2.

${ }^{2}$ This building should, apart from being the home of the congregation in Reykjavík, be large enough to comprise the gatherings of all the churches. It should further house a health clinic and provide office and administrative space for the central base of the Mission in Iceland. Kristjánsson, 42.

${ }^{3}$ This led eventually to the dissolving of the Hafnarfjörður church and a merger of it with the one in Reykjavik. As further ways to raise funds for the building project a special collection among the members was planned, the special issue of Tákn tímanna was to be sold, and a request was to be made to the General Conference for assistance. Ibid.

${ }^{4}$ O. J. Olsen, "Kirkjuvígsla," Bræðrabandið, February 1926, quoted in ibid., 55. 
additional 41 were baptized-61 in all. During these years Olsen also had public meetings in the new church in Vestmannaeyjar as indicated earlier. During these years then from 1924 when the first baptism took place in Vestmannaeyjar, to the end of 1927,130 people were added to the church in these two places. But Olsen and his coworkers were not satisfied. They now prepared plans to reap the harvest among those in other parts of the country who had so willingly received the colporteurs.

\section{Olsen's Comprehensive Plan of Mission}

In 1926 Olsen and his coworkers developed a bold plan to spread the Advent message to all the major inhabited areas of Iceland that had not been reached by public efforts. "He planned to evangelize all the major towns of the northern coast, move eastward, and slowly go around the entire coast of Iceland. Places such as Vestmannaeyjar and Fáskrúđsfjörður (in the east) were exceptions to this plan, and other exceptions were made where a special interest had developed."

During these years the colporteur work was becoming successful again (see above), which prompted Olsen to write in a news item in 1929: "There can now hardly be found a single home in the whole of Iceland that has not received some of our literature; and the seed now begins to show some results."2

His first place of concentration was Siglufjörður, a town in the extreme north of the country, where Olsen worked on and off for two years, 1928 and 1929. This place had grown even more rapidly than other fishing settlements in Iceland due to enormously rich

\footnotetext{
${ }^{1}$ Ibid., 58.

${ }^{2}$ O. J. Olsen, "Island," Missionsefterretninger, January 1929, 4, quoted in ibid.
} 
fishing years, especially in herring, in the nearby waters. ${ }^{1}$ In 1929 a church was formed in Siglufjörður with about fifteen believers and a small house built where they could assemble. In 1930 Olsen then started work in the nearby town of Akureyri, then a town of about four thousand people, ${ }^{2}$ the second largest urban settlement in Iceland at the time and recognized as the central and most important town in the northern part of the country. Even though Olsen "considered Akureyri the most difficult town in Iceland to evangelize he gathered a group of ten or twelve individuals to form a Sabbath School there early in 1930." ${ }^{\prime 3}$ A church was formed in Akureyri in 1933 after Olaf Frenning, a Norwegian man who had joined the worker force in 1930, had labored there during the winter 1932-1933, with six people baptized, and a building was erected the same year. ${ }^{4}$

In 1931 Guðmundur Pálsson started work in the eastern section of the country where no real impact had yet been made. During the thirties a few individuals were baptized there, the largest group of eight people in 1939 in the small town of Fáskrúðsfjörður. Five more joined in 1941 and 1942 when a church was formed there of about fifteen people.

${ }^{1}$ In 1910, 654 people lived in Siglufjörour, 1,159 in 1920, and 2,022 in 1930, an average annual growth rate of almost $40 \%$. Statistical Yearbook of Iceland. During the herring season in the twenties and thirties the population of Siglufjörður grew to 15-20,000 with people from all over the country working in the processing plants or on the fishing boats. Boats from many foreign countries also landed their catch in Siglufjörður during those "Klondike" years.

${ }^{2}$ The population composition of Akureyri was much different from Siglufjörður and Vestmannaeyjar. Traditionally it was a town much influenced by the long-standing presence of Danish traders and government officials and even though it enjoyed about 40\% growth from 1920-1930 (from 2,699 to 4,583 inhabitants) the atmosphere there was much more settled and conservative than in the other towns I have discussed.

$$
\begin{aligned}
& { }^{3} \text { Thordarson, } 78 . \\
& { }^{4} \text { Ibid., } 79 .
\end{aligned}
$$




\section{Olsen's Contribution, a Summary}

In 1933, after Olsen had worked valiantly in Iceland for twenty-two years, he was called back to Norway where he served as leader of the Onsrud Mission School until 1936. ${ }^{1}$ This seems to have caught Olsen by surprise and caused dismay with him and among the members in Iceland. W. T. Bratlett reports it thus in the Review and Herald: "It was with heartfelt grief that leader and people responded to such a call." Olsen's own response was as follows: “'The Lord's ways are not our ways.' There is no Bible passage that is sometimes as difficult to understand as this one.... When I stood on the ship and saw those last white mountaintops disappear on the horizon, I couldn't help asking "Why?" In Iceland I have fought my battles hardest, ... but also won my greatest victories."3

These are the words of a man who had lost his heart to the cause for which he had devoted his life. They betray also a complete loyalty to his church, causing him to accept the call rather than him questioning the wisdom thereof. Olsen's sentiments are understandable in view of the recent developments in the church in Iceland and the great unfinished business he was leaving behind.

During this first period Olsen and his associates had through hard work and God's grace, but against considerable odds, succeeded in establishing a church in Iceland that without doubt had come to stay. Under his leadership the mission had survived the near

'Olsen served a second period in Iceland from 1936 til 1947 when he was called to the post of Field Secretary at the Northern European Division. 60.

${ }^{2}$ W. T. Bratlett, "Iceland," Review and Herald, 23 November 1933, 24, quoted in Kristjánsson, 61.

\footnotetext{
${ }^{3}$ O. J. Olsen, "Island-Onsrud," Braðrabandið, September-November, 1933, 81, quoted in ibid.,
} 
fatal catastrophe of the dismissal of its first very able and popular proponent, David Östlund, and his ensuing public encounter with the Union representatives, which well could have spelled the sudden end of the Adventist mission in Iceland. Then Olsen had been able to become familiar with the national spirit in Icelandic and to communicate with the present needs in society through extensive colporteur activity and evangelistic campaigns so as to significantly impact the population at the time and cause considerable growth in membership. Thus, at his departure, Olsen left behind in the country two relatively strong churches and a number of smaller companies and a general awareness within the population as to the identity and objectives of the Adventist cause.

\section{A Period of Reduced Growth}

The Challenging of Diminished Results

Following Olsen's departure in 1933 the leadership was in the hands of Olaf Frenning who served as vice president of the Iceland-Faeroe Islands Conference. ${ }^{1} \mathrm{He}$ and Guðmundur Pálsson kept up a similar emphasis as Olsen had done, but much of their time now went into maintaining the churches that had been established and to seek to sustain and consolidate the rapid growth that had taken place in Vestmannaeyjar and Reykjavík. Further pressure on them was caused by the responsibility to supervise the

\footnotetext{
${ }^{1}$ In 1930 Iceland and the Faroe Island field had been united in a Conference, the Iceland-Faroe Islands Conference under the Nordic Union (from 1931 West Nordic Union). Iceland mission was initially supported by the General Conference. After the reorganization in 1901 it came under the General European Division (later European Division), then in 1904 it was placed under the Nordic Union, and in 1923 again under European Division (1928 Northern European Division), until 1930. O. J. Olsen served as president of the Conference until 1947. For 3 years (1933-1936) O. Frenning served as vice president. SDA Encyclopedia, 1975 ed., s.v. "Iceland."
} 
work in the Faeroe Islands which called for regular visits. ${ }^{1}$ In spite of this growing strain on the workers they still continued to give attention to the ambitious plan of expanding the work, both in the north and the east, work that was to yield some fruit a few years later.

But it is clear that the number of people responding to the proclamation during this period was much smaller than just five to ten years earlier. In fig. 1 where the number of baptisms in the country as a whole is shown at five-years intervals, it is clear that a marked decline in growth sets in the 1930s, a decline that continues well into the next decade as well. Several possible reasons for this decline in growth may be suggested. One has been alluded to as being the inability of the few workers to keep up the momentum due to the spreading out of churches and companies that had been raised up. Thus the fundamental tenet of Olsen's strategy: to reach the whole country and raise up companies and churches in all major urban settlements, may have become a major weakness of his project due to the unsustainability of the work in many of the places. This was inherent in the smallness of the population in each place leading to mostly very small groups of believers who were dependent on frequent visits and were often maintained in their early phases by the presence of one or two dominant individuals or families. Thus these groups were very sensitive to the migration of supportive people from the community, something that frequently happened in a highly mobile and rapidly changing society.

\footnotetext{
${ }^{1}$ The baptismal records of the Conference show some significant activity there as baptisms were taking place nearly twice a year during 1934-1938 calling for visits by the Conference officials.
} 


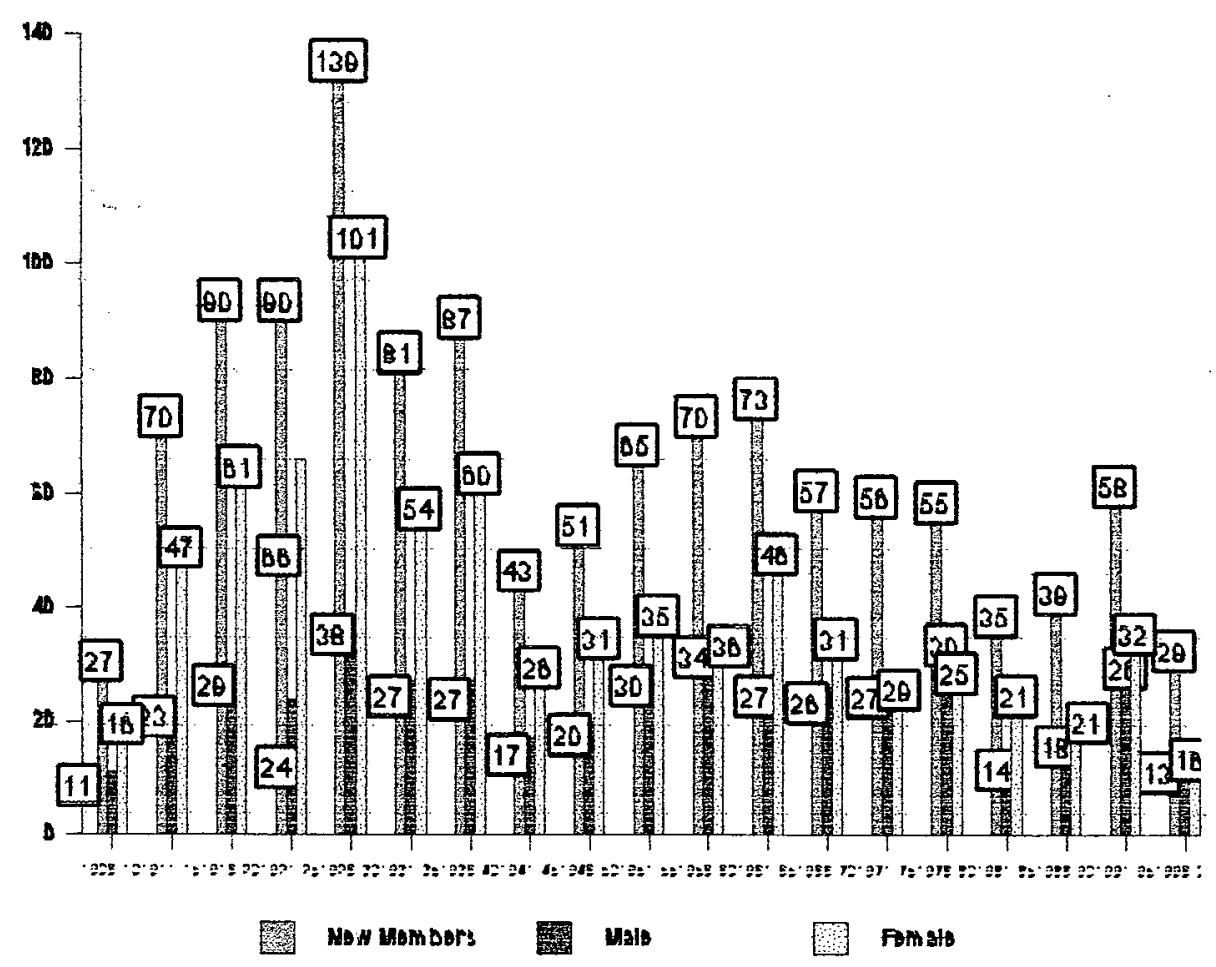

Figure 1. All new members, 1906-2000.

Further difficulty in maintaining the program was caused by finances and geography as long distances, expensive and unreliable means of transportation due to poor roads and unpredictable weather, made travel difficult. This was compounded by the length of the evangelistic campaigns thought necessary at the time, frequently three to four months, absorbing the evangelist almost fully for that period. ${ }^{1}$ Further, a more fundamental problem existed in the lack of independence of even the bigger churches. The Reykjavik church, being the central church and the administrative center of the Conference, was in need of constant attention of church workers in connection with its operation but especially with regard to evangelism. Also the church in Vestmannaeyjar, 
in spite of the fact that it soon enjoyed a vibrant church program and rich resources in youth and able lay-leaders, did not maintain evangelistic projects without Olsen (or another evangelist) being the prime focus of the event. Clearly, and understandably so, the great ability and reputation of Olsen as the eminent evangelist created an image in people's minds, not only in Vestmannaeyjar, of evangelism as a highly specialized area of expertise necessarily mastered in order to present Adventism to the public. Clearly Olsen did not succeed in downplaying this notion and did not emphasize the training of the members for their active involvement in evangelism. ${ }^{1}$ Thus the program that was operated by the conference both with regard to member care and nurture and evangelism was a recipe for the creation of dependent churches, which probably was particularly unfortunate in the Icelandic setting as I have pointed out. Regrettably, the inherent difficulty in maintaining the many small churches described here was becoming very evident as they were dissolved almost at the same rate as they were established. ${ }^{2}$

Even though these factors that I have mentioned had their effect, it still does not account fully for the decreasing success of the evangelistic campaigns in the latter part of the 1930s and onwards. In spite of the fact that the work in far corners of the country occupied the men, meetings were still run in Reykjavik and Vestmannaeyjar, but with

\footnotetext{
${ }^{1}$ But it must be pointed out that the very prominent role of a single evangelist was not uncommon in Adventist evangelism at the time. It was probably the rule rather than the exception.

${ }^{2}$ The Hafnarfjördur church, established in 1915, sold its building in 1922. (In 1992 a church was again established in this town as a result of successful evangelism run by Pórðarsson.) The Eyrarbakki church seems to have ceased to meet quite quickly after its organisation. In Bolungarvik (church established in 1920) it was not deemed necessary to keep the church building in 1934/5, presumably as it was not in use. The church may have been dissolved about a decade later. This became subsequently also the fate of the churches in Siglufjörður, Akureyri (even though a company operates there now), Fáskrúðsfjörður, and Skagastönd.
} 
diminished results. In 1936 Olsen returned to Iceland where he served till 1947 as mentioned above. Even his campaigns in both these places and elsewhere were neither drawing the crowds nor producing the results earlier experienced. Lack of biological growth was also affecting the churches in the 1930s as children of church members were not joining the church at a satisfactory rate as revealed in fig. 2 .

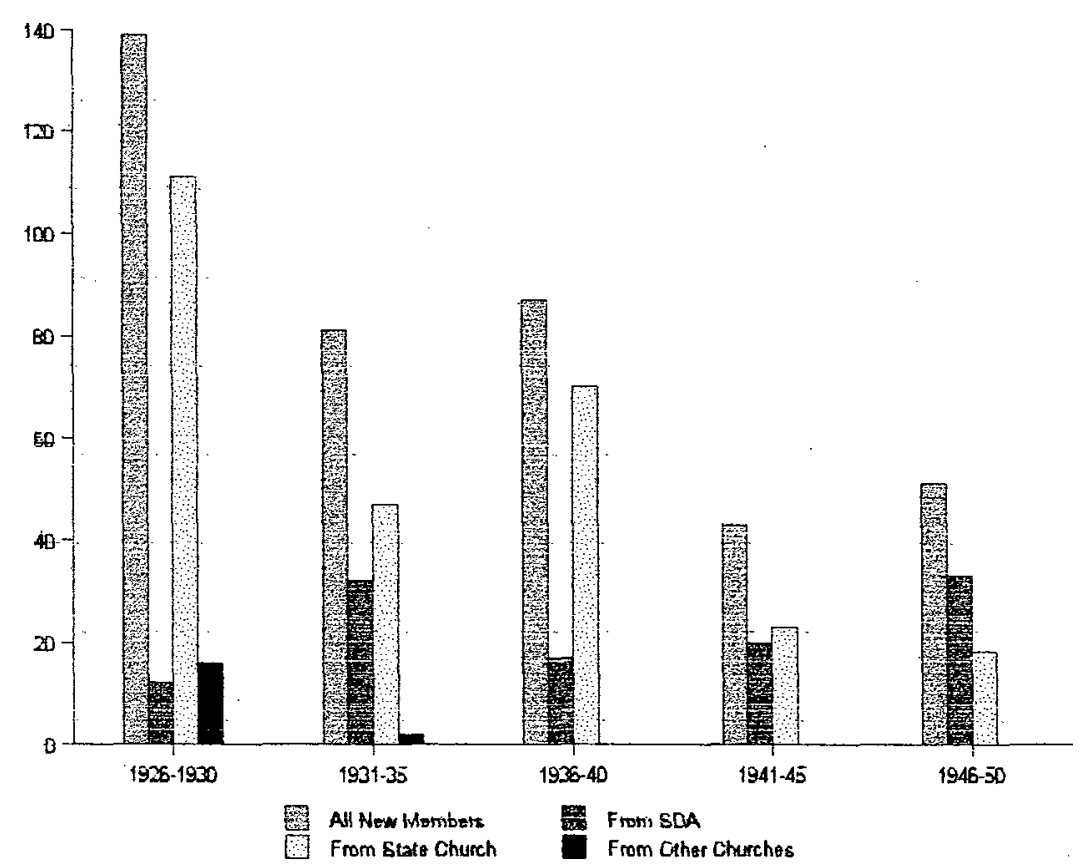

Figure 2. Denominational background of new members, 1926-50.

Steinpór Póröarsson's $\mathrm{s}^{1}$ theory is that the start of decline in growth and the collapse of the many smaller churches at this time was due to emerging institutionalization of the church in Iceland, specifically due to the rise of a phenomena

${ }^{1}$ Steinpor Fórðarsson, “A Study of Factors Related to the Numerical Growth of the Seventh-day Adventist Church in Iceland 1950-1980," (D.Min. dissertation, Andrews University, 1985). 
akin to the "school approach" to church growth described by McGavran. ${ }^{1}$ Pórðarson sees this as having set in already by the end of the 1920 s when the two main churches established church schools. ${ }^{2}$ I will devote a section later in this chapter to this discussion. It seems more likely to the present writer that the establishment of church schools was simply done to provide Christian education for the children of members and to boost internal church growth. The establishment of a youth department, which I will now describe, was another move to strengthen the church internally.

The Establishment of Conference Youth Department

As a reaction to the described need in the churches in Iceland a worker was called to serve the youth in Iceland in 1938 . The Division representative at the Conference Session in Reykjavik that year advised the leadership to call Júlíus Guðmundsson, an Icelander who had prepared himself in Denmark and England for ministerial service to cater for the youth work. ${ }^{3}$ Guomundsson, the first native of the Adventist church in Iceland to receive training and ordination for ministry, served as Youth Director until 1947, residing in Vestmannaeyjar from 1941, where he also taught in the church school. The work for the youth during this period included the introduction of the Junior Missionary Volunteer program in four divisions which was then being implemented in

${ }^{1}$ McGavran, Understanding Church Growth, 12-14.

${ }^{2}$ Church school was established in 1928 by the Vestmannaeyjar church (see Kristjánsson, 59) and the same year by the Reykjavik church.

${ }^{3}$ Guoxmundsson, a farmer's son from southern Iceland, was baptized in Vestmannaeyjar 1928. After earning his way by colporteuring he left for Denmark the following year where he studied at Vejlefjord Mission School and then one year at Newbold College, England. From there he was recruited as ministerial intern in Denmark working as assistant to such evangelists as E. C. Westman and A. Guldhammer for three years until he was assigned to a ministerial post in the Faroe Islands in 1938 . He attended the Conference Session in Iceland before taking up his duties there which led to his redirection to Iceland. The Division representative at this Session was T. T. Babienco. 
Scandinavia. ${ }^{\prime}$ Summer youth camps also became a part of this program; they enjoyed great popularity and soon turned into family camps. Attendance rose every year soon to become above $200,{ }^{2}$ Further, the Youth Department became responsible for the monthly youth magazine Viljinn, which initially had been issued by the youth society of the Reykjavik church. The work for the youth increased the baptismal ratio of the children of church members as indicated in fig. 2 where the number of baptized individuals from an Adventist background is shown to have risen steadily in the period 1936-1950, while the number of baptisms from a non-Adventist background is decreasing significantly. With view to the increasing number of youth within the church it was at this time thought necessary to establish a secondary school in Iceland. The fulfillment of this aspiration, an impressive undertaking for a small constituency, became the overriding goal of the church in the late 1940 s.

\section{The Contribution of Hliðardalsskóli}

At its constituency meeting in 1947 the Iceland Conference voted to establish a boarding school at a location already purchased in the countryside $50 \mathrm{~km}$ east of Reykjavik. In this action the objective of the institution was clearly stated which was the traditional one in Adventism: To offer state-required education advised by Adventist educational philosophy to the youth of the church within the church's sphere of influence in order to preserve them and to orient them towards missionary service at home and

\footnotetext{
${ }^{1}$ During this period 71 individuals took part in this program, 22 in Reykjavik and 49 in Vestmannaeyjar. In addition to regular JMV program and frequent youth meetings in the church a variety of evening courses were offered that were well received also by older people. Gudmundsson, 21 .

${ }^{2}$ Ibid., 18
} 
abroad. ${ }^{1}$ The school was built and ready to receive the first students in the fall of 1950 under the leadership of Guðmundsson. Guðmundsson served at the same time as conference president. ${ }^{2}$ The establishment of the school was the largest and most ambitious project the church in Iceland had embarked on, costing much concentration of

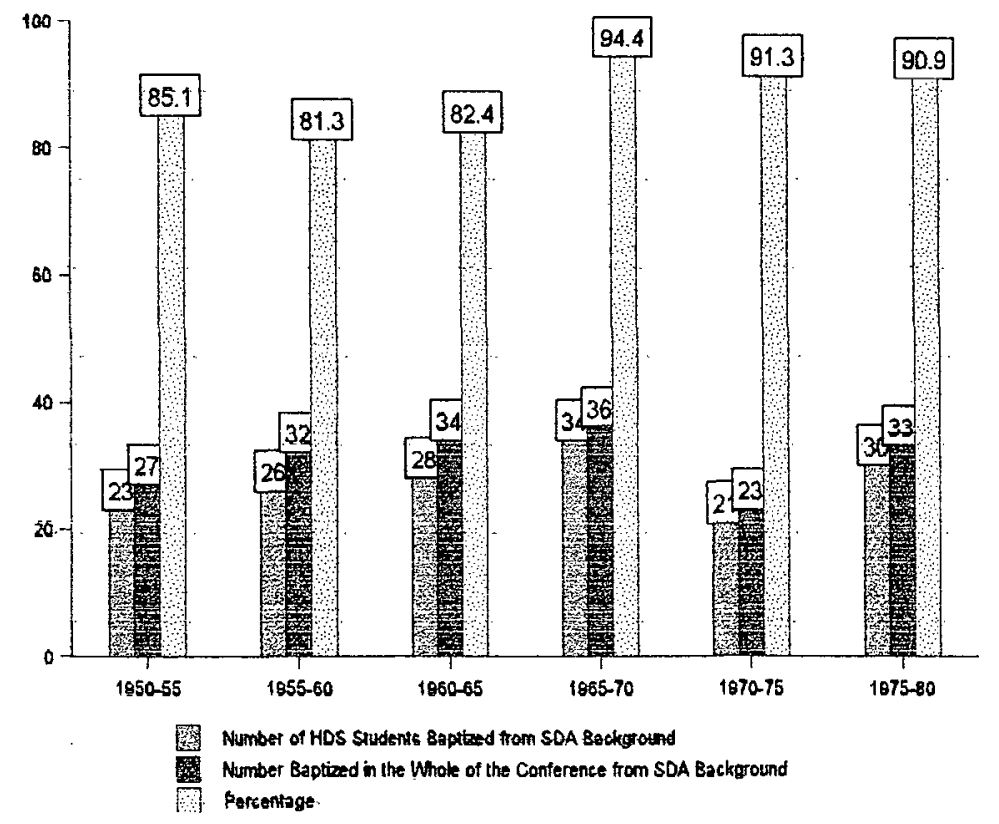

Figure 3. Baptisms of individuals from SDA background, 1950-60.

${ }^{\text {lat }}$ Since we are instructed by the Word of God and the Spirit of Prophecy that the young are to receive in our own schools the education they need for their daily life and to do the work of redeeming souls in other countries, it is resolved: that a mission school be established in Iceland on the land which the conference committee has bought this year; that the aim of the school be to educate the young to become missionary workers, and to give instruction which enables them to take up the various tasks of life and strengthens them against the many temptations of modern times, and also prepare them for 'Gagnfræðaprof' (General Certificate if Education)." Iceland Conference of Seventh-day Adventists (Reykjavík, Iceland), Minutes of meetings of the Conference Committee, May 1947, quoted in Bórðarson, 85.

${ }^{2}$ From 1947-1949 GuJmundsson led the newly begun Bible Correspondence School. In 1949 he. became the conference president, succeeding Johannes Jensen (from Denmark) who had taken over when Olsen left in 1947 for a position as field secretary of the Northern European Division. Guormundsson was. president until 1968, the 10 first years also serving as the principal of the new school. 


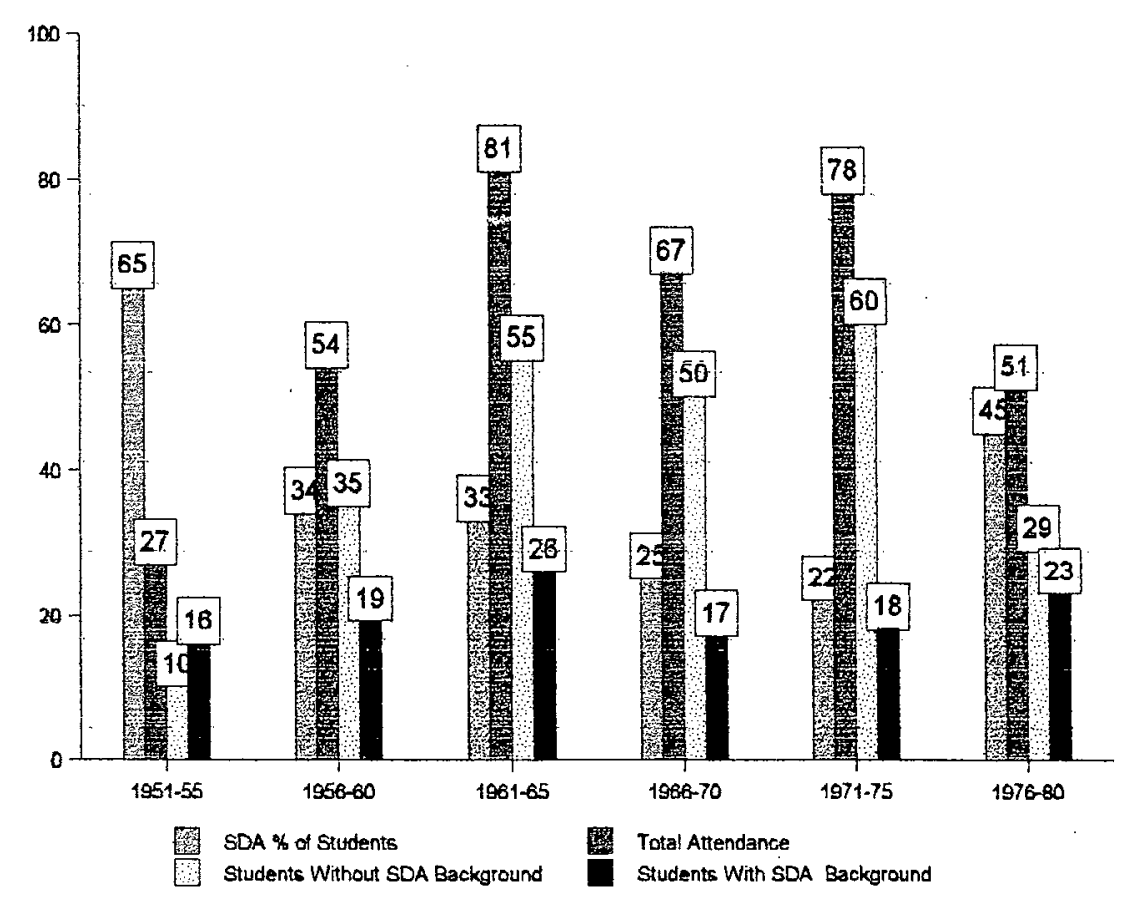

Figure 4. Average per year student attendance at HDS, 195180.

effort. But from the beginning it was successful. Many students from an Adventist background were baptized during the years 1951-1980, which is shown in fig. $3{ }^{1}$ It also shows that on average in the same period close to 90 percent of all those who made a decision for baptism from an Adventist background did so under the influence of the school. The high quality of the school program was very quickly noticed in Iceland and attendance of non-Adventist students rose steadily until students from an Adventist background were a clear minority of the student body (see fig. 4). Still, for many years, the Adventist flavor of the institution was kept intact and some of the students from nonAdventist homes joined the church while attending, some of whom became leading

${ }^{1}$ Figures 3 and 4 are based on a chart that appears in Póroarson, 232. The chart was prepared in 1982 by Guðmundur Ólafsson, a former teacher and principal at Hliðardalsskoli. 
individuals within the church in later years.

Figures 4 and 5 portray this development. Figure 5 shows that altogether fortyeight students of Hliðardalsskóli from a non-Adventist background were baptized from 1951-80, which constituted 26.3 percent of all baptisms from non-SDA background in the Conference in that period. From figure 6 can be gathered that about 56 percent of the total number of baptized individuals in this period were influenced by the school.

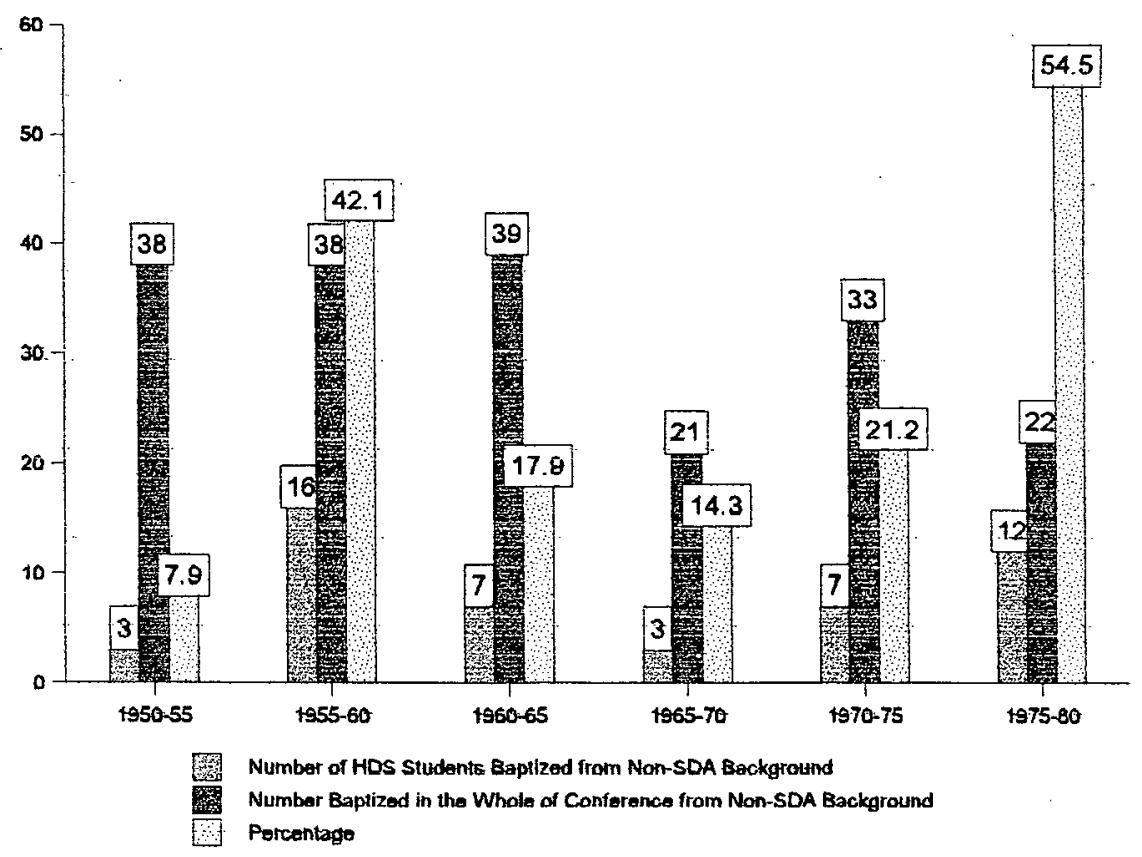

Figure 5. Baptisms of individuals from non-SDA background, 1951-80.

The impact of this rapidly growing institution on the whole project of the church in Iceland is difficult to estimate fully, but may perhaps be summarized in relation to its effect on the following groups: The youth of the church; The youth among the general 


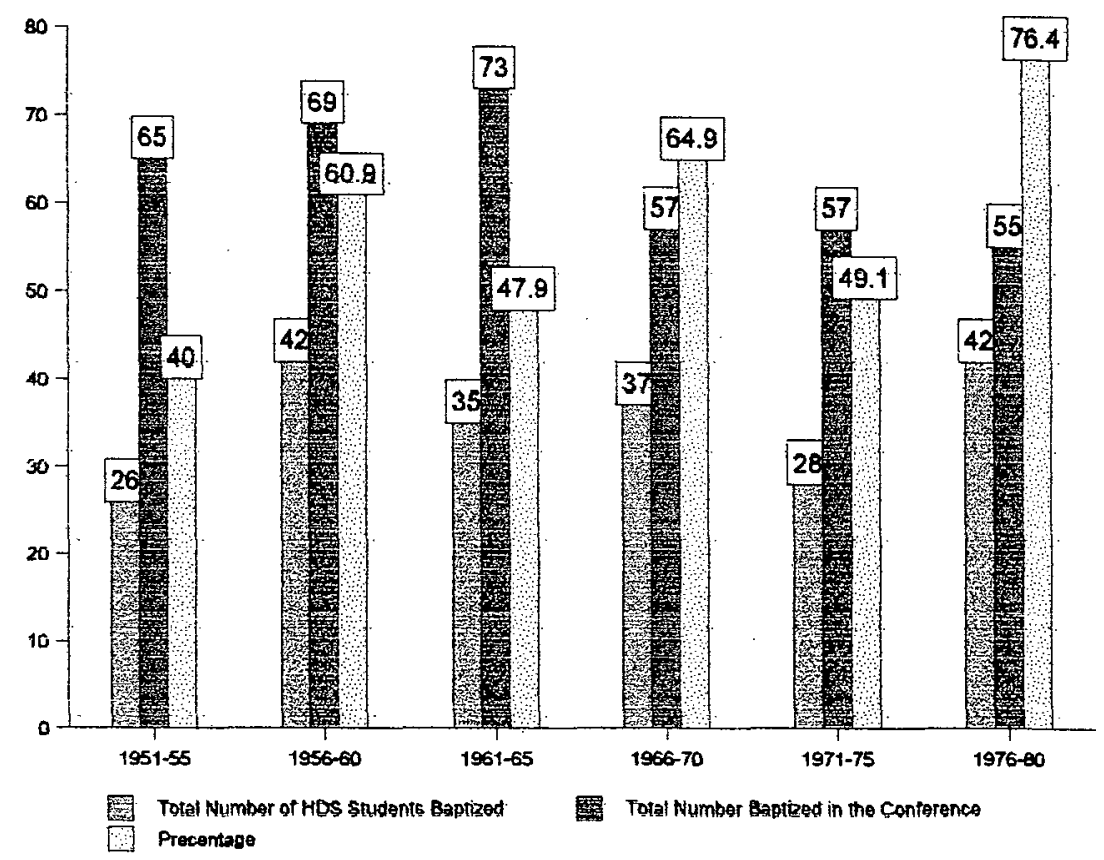

Figure 6. Total number of individuals baptized, 1951-80.

public; The public image of Adventism in Iceland, and the Adventist church in Iceland as a whole.

The Impact of Hlíoardalsskóli on the Youth of the Church

During its first three decades of its operation the school must be said to have fulfilled its main objectives of preserving and instructing the youth of the church albeit in a somewhat different format from originally intended due to the influx of students from the general public. Due to effective management Adventist ideology and spiritual values still controlled the program of the institution, and an environment was maintained where to identify with the church was not unattractive either to the youth with an Adventist background or to some students from the general public. This milieu may have become particularly favorable for the transmission of faith from one generation to another where 
an expression of personal position of faith was often required with non-Adventists present but still most often in a sympathetic environment.

\section{The Impact of Hlíðardalsskóli on Young People from the General Public}

As mentioned above the effect of the program of Hliðardalsskóli academically speaking as well as with regard to general upbringing was considered to be excellent. Students attended the school from far and wide in Iceland and took home with them a rich and maturing experience of their encounter with Christian education philosophy, concentrated effort towards academic improvement and, in some instances, a living relationship with Jesus Christ as their Lord and Savior.

\section{The Impact of Hlíðardalsskóli on the Public Image of Adventism in Iceland}

The activity and reputation of Hliðardalsskóli had a substantial impact on the public image of the Adventist church in Iceland. Apart from the report brought home by students, quite often favorable articles appeared in newspapers about the school. Furthermore, a summer sanitarium was run at the school during the summer holidays from 1954-1964 offering wholesome food, physical therapy and hydrotherapy treatment in peaceful surroundings. This became quite popular at the time. ${ }^{1}$ Also the teachers of the school as a team visited all the towns and villages in Iceland in the annual Ingathering Campaign as for a time Hliðardalsskóli received an appropriation from the funds

${ }^{1}$ Gudmundsson, 35-69. A chapter in this little booklet contains a collection of newspaper articles and letters by prominent people in Icelandic society where they comment favorably on the program of the school and the summer sanitarium. 
collected in exchange for regular appropriations from the Division due to restrictions on currency exchange in the country at the time. All this contributed to making Hliðardalsskóli known in the mind of the people in the country, and its philanthropic program helped to create an image of the Adventist church as one which sought to propagate practical, society-enhancing Christianity.

\section{The Impact of Hlíðardalsskóli on the Adventist} Church in Iceland

As mentioned above the churches in the 1930s and 1940s started to encounter diminished effect of their evangelistic programs and even difficulty in maintaining their own young people within the church. This led to increased emphasis on the internal program of the church such as the operation of church schools and emphasis on youth work. This tendency was reflected within the church in Vestmannaeyjar where the members, for obvious reasons, sought self-sufficiency in so many ways that they had diminished contact with the surrounding society (see discussion above). An inclination may have been developing within the church that was more inward looking, protectionist and isolationist than had been the case earlier when colporteur work and effective and successful public campaigns had been the order of the day. The setting up of the Mission School at Hliðardalsskóli had also been in the interest of maintaining the church by keeping the youth within it and protecting it from the corrupt influence of the world (see above statement of purpose of the school). It then so happened that the implementation and development of the school program was led, perhaps inadvertently so, on a different course as students from the general public soon flocked to the school. This, however, 
may have been a providential means of breaking out of the separationist course to a healthier and more constructive one, both for the Adventist youth and the whole mission project of the church.

\section{Reasons for Changes in Growth Pattern}

It is of major interest in this study to understand what caused the changes in the growth pattern of the church in Iceland during the first decades of the work, especially the rapid growth taking place roughly from the beginning of World War I until the end of the 1920 s and then the reduced results in the 1930s of public evangelism in the main centers (Reykjavik and Vestmannaeyjar) and a slowly grinding to a halt of the bold strategy of spreading the "Advent message to all the major towns ... of Iceland." I have tried in this chapter to provide necessary information to come to an understanding of the reasons for growth and non-growth at this time as this may be of great value to us when seeking to map out future strategy.

\section{Institutionalization of the Church}

Steinpór Pórðarsson has understood this and has made the discussion of this pivotal period in the history of the church central in his paper. A short summary of his view of the development might be the following: During the most successful period of Olsen's tenure the evangelization of the whole of Iceland was well under way through a systematic work strategy referred to above. The work was effective, as a division of labor was maintained between Olsen and his coworkers: colporteurs, missionaty evangelists

\footnotetext{
${ }^{1}$ Kristjánsson, 57.
} 
and Bible workers. Often they would work in a particular town to prepare the ground and then Olsen would arrive on the scene, baptize those who were ready to join the church, and form a church if conditions were ripe. Then the team would move on to another place. "This was a wise strategy," Pórðarson comments, "as it steadily added to the membership of the new, fledgling church." A gradual breakdown of this pattern then occurs as less growth takes place and even a disintegration of the small churches along the coastline sets in as some of the churches were dissolved and their houses of worship sold. ${ }^{2}$ Pórðarson seeks to come to terms with this tragic turn of events and he sees as a possible reason for this the lack of nurture and follow-up of the smaller churches, but is convinced that the main reason is "the leaders' pre-occupation with Christian education, for these absorbed the energies and resources of the church. The successful operation of the Vestmannaeyjar church school (opened in 1928) and of Reykjavík church school (reopened in 1946) increasingly occupied church leaders with matters of Christian education. Evidently, the gradual switch in emphasis in church activities from public evangelism towards schools and Christian education was made at the expense of church growth."3

pórðarson further sees this change of fundamental philosophy come to full fruition in the establishment of the secondary school as an opinion was gradually shaped among church leaders to "consider it the chief instrument for achieving church growth."4

\footnotetext{
'Bórðarson, 92.

${ }^{2}$ Ibid., 94.

${ }^{3}$ Ibid., 93.

${ }^{4}$ Ibid, 172.
} 
This pórðason sees as the primary reason for decline of progress in the church: "After Christian education became the dominant outreach program in Iceland conference, from 1950 , the rate of growth diminished markedly. Organization of a new congregation has not taken place since $1952 . " 1$

Pórðarson then continues to elaborate how this institution had absorbed manpower and financial resources for decades and drawing the attention of administrators from the weightier things of direct evangelism. Finally, he seeks to correct what he finds to be a common misconception in the mind of many church members-that this institution has been an effective evangelistic avenue-pointing out that more people joined the church from the community in the period 1951-1980 through other means. "Contrary to common opinion among Adventists in Iceland, Hliðardalsskóli has not been the greatest contributor to church growth. According to the survey, the school tied for fourth place - together with SDA books and pamphlets."

Pórðarson finds support for his argumentation in Donald McGavran's description of the "school approach" as having delayed growth in the churches in East-Africa. ${ }^{3}$

All this seems on the surface to paint a plausible picture of the turn of events and the reason for the downward trend with regard to growth of the church in Iceland at the time in question. I would suggest however that Pórðarson has neglected to take account of the historical facts in several ways, which has led to a superficial analysis of the problems.

\footnotetext{
${ }^{1}$ Ibid., 113.

${ }^{2}$ Ibid., 172.

${ }^{3}$ McGavran, Understanding Church Growth, 12-14, qouted in ibid., 25-27.
} 


\section{Other Reasons-The Theory of Receptivity}

In this chapter I have sought to describe the cultural climate in Iceland at the turn of the twentieth century into which the Adventist mission entered, which, I have suggested, made segments of the nation receptive to the message of the church in the way described by McGavran.' By way of summary he states: "The experience of the church indicates that immigrants in a new country, mi-grants to a city, society suffering from deprivation or shock, and the oppressed hear and obey the gospel more readily than contented beneficiaries of the social order."2

The duration of this condition in society is unpredictable: "How long does receptivity last? It is impossible to foretell. One thing is clear-receptivity wanes as often as it waxes. Like the tide, it comes in and goes out. Un-like the tide, no one can guarantee when it goes out that it will soon come back in."3

The conditions in Iceland at the turn of the century were, as we have seen, extraordinary. Suffice it to recapitulate a few influencing factors: Nationalism, intellectual renewal and the struggle for independence and the transition from a colony to a nation produced social, political and economic turmoil. This coincided with a rapid secularization process of society and the near spiritual bankruptcy of the State Church and its misguided, disastrous bid for renewal through liberal theology and spiritualism,

'McGavran, Understanding Church Growth, 179. Receptivity McGavran defines as "the varying ability of individuals and societies to hear and obey the gospel."

${ }^{2}$ Ibid., 131. See also 179-192, a chapter entitled "The Receptivity of Individuals and Societies," where McGavran deals with this concept in greater detail.

${ }^{3}$ Ibid., 181 . 
creating a spiritual vacuum into which religious pluralism was introduced. Further, the enormous social spiritual and economic repercussions of sudden, rapid urbanization from rural farmsteads to towns contributed to a state of transition for sizeable segments of society.

It is my theory that these conditions made segments of the nation receptive to the message of the church's representatives during the first decades of the century and that this receptivity waned as time went on and conditions in society changed. As we noticed, Iceland gained an important milestone in its struggle for independence in 1904, 1918 and finally 1944 . The population growth of many of the new urban settlements had become stable by the second decade, people's social and spiritual needs were being met and increasing economic independence within society was achieved. In other words, in the 1930s conditions that had made success stories in the mission of the church like that of Hafnarfjörður in 1914, Ísafjörður, Hnifsdalur and Bolungarvík in 1920, and Vestmannaeyjar in 1923 were no longer present. ${ }^{2}$ And then during and after the second World War quite a radical social change took place with increased economical affluence for the nation.

Still it must be recognized that the growth of the church in the period in question did not come without a valiant effort and a careful, deliberate strategy on behalf of the representatives of the church. The sequence of the components of the strategy was

\footnotetext{
${ }^{1}$ It seems likely that similar conditions of deprivation that were described above as evident in Vestmannaeyjar in the 1920 s creating a very receptive environment there may have been present in varied degrees in other urbanized areas in Iceland during this period. ${ }^{2}$ The success in Siglufjörour 1928-30 was an exception as conditions were unique there as
described above. ${ }^{2}$ The success in Siglufjörour 1928-30 was an exception as conditions were unique there as
described above.
} 
undoubtedly significant. First, the emphasis on the publishing work: Initially the ground was broken with the phenomenally successful and culturally sensitive church paper/evangelistic magazine Frakorn, and then, with the arrival of Olsen, the whole country was covered with appropriate literature. Then evangelistic campaigns were successfully conducted and churches raised up. Also, as we have noticed, in their approach these men demonstrated amazing foresight, wisdom and cultural sensitivity which certainly also affected the end result.

\section{Lack of Manpower and Introversion}

As the work fell on harder times in the late 1920 s and the 1930 s due to decreased response to public evangelism, other difficulties compounded the situation. I pointed out that the maintaining of the small and scattered churches and companies and the responsibility for the work in the Faroes became difficult, especially in the mid-1920s and onwards as economic recession caused financial restraints which also led to the practical stand-still of the colporteur work for a period. The combined effect of these conditions made it difficult for the churches to maintain earlier growth, especially by pursuing earlier methods.

As a further negative trend it was proving increasingly difficult for church members to keep their children within the church. The decision then to open schools should not be seen as a deliberate change of evangelistic strategy by Olsen and the leaders of the churches, as if schools were now to be the doorway to the church, but as an awareness of a need to provide Christian education for their children and an attempt to keep them within the church. 
As a further measure to ensure this, a worker was hired by the Conference whose main responsibility it was to work for the youth of the churches. This must be seen as a significant event in the history of the church as until then all paid personnel of the church had mainly been engaged in activity related directly to soul-winning. What was taking place here may be an expression of what McGavran talks about as a common turn of events in churches that have experienced rapid growth:

It often happens that after a period of rapid growth, a church in a responsive area will slow down and become introverted, or turn its attention to cultural advance. ... It enters a static stage of its existence. Sometimes growth stops because the kind of converts who constituted the first source of growth are no longer available, and the church does not seek a second source. Often, however, the same kind of converts are available but the emphasis has changed - new pastors or missionaries have come who are busy perfecting the existing Christians and the absence of growth continues.

It seems that a more consolidating, introverted attitude was created but out of a need rather than as a deliberate change of program. Still the colporteur tradition was continued vigorously every year when conditions improved ${ }^{2}$ and evangelistic programs were run every year but with diminished results. It must be remembered that six churches and companies were formed in a period of twenty-two years after 1928 when the schools were started.

\section{Appraisal of Early Period of the Mission in Iceland}

I have spent time on the analysis of this early period of the work in Iceland as it seems that the groundwork laid by the 1930 s to 1940 s has characterized the church ever

\footnotetext{
${ }^{1}$ McGavran, Understanding Church Growth, 99.

${ }^{2}$ Books were again produced in 1927 and the colporteur program was revived after a period of slow activity. Kristjansson, 58, 59.
} 
since. The church grew very rapidly and then entered a phase of slower growth and even dissolution of churches, and soon a significant number of new members were to make the decision for Christ under the influence of the secondary school, Hliðardalsskóli, rather than through public evangelism.

But this development was not inevitable. Growth and the planting of new churches could have continued without straining the supporting structure of the mission to its limits. ${ }^{1}$ A weakness in the program of the mission, seemingly present from its inception, became especially apparent at the change of climate after the initial period of rapid growth which led to difficulty of sustaining earlier levels of evangelism and nurture.

First, the churches were characterized by pastor dependency. The leadership failed to create an environment of recruiting and equipping local leaders so as to make them become independent and self-sufficient. This may sound contradictory as many of the smaller churches were isolated and pastoral attention was irregular. Still local leadership lacked endorsement and qualification to carry out necessary spiritual nurture in the churches, and especially they felt wholly inadequate to carry out any major evangelistic work which was looked upon as a highly specialized venture. This led to the highly reduced ability of the churches to unfold as fully operational evangelistic entities within their own areas and thus also to reproduce themselves. It is not that the members were not intensely serious and faithful Christians or longed for growth in their churches, but the above flaws in the program did not permit the implanting of the full vision of a

\footnotetext{
${ }^{1}$ See discussion above. At his departure in 1933 O. J. Olsen was suffering from a near physical breakdown as he had overtaxed himself in trying to care for the work in Iceland and the Faroes.
} 
self-sustained church. ${ }^{1}$ A group, then, that has as its main objective to maintain its own spiritual nurture and distinctness and to keep the company together, tends to become insular and wary of worldly influence and consequently limits itself further in its ability to recruit new members.

\section{Subsequent Developments}

Let us now examine subsequent development and growth figures for the Iceland Conference as a whole on the one hand and then bring this chapter to a close by looking closer at each individual church and analyze their growth from 1995 to 2004.

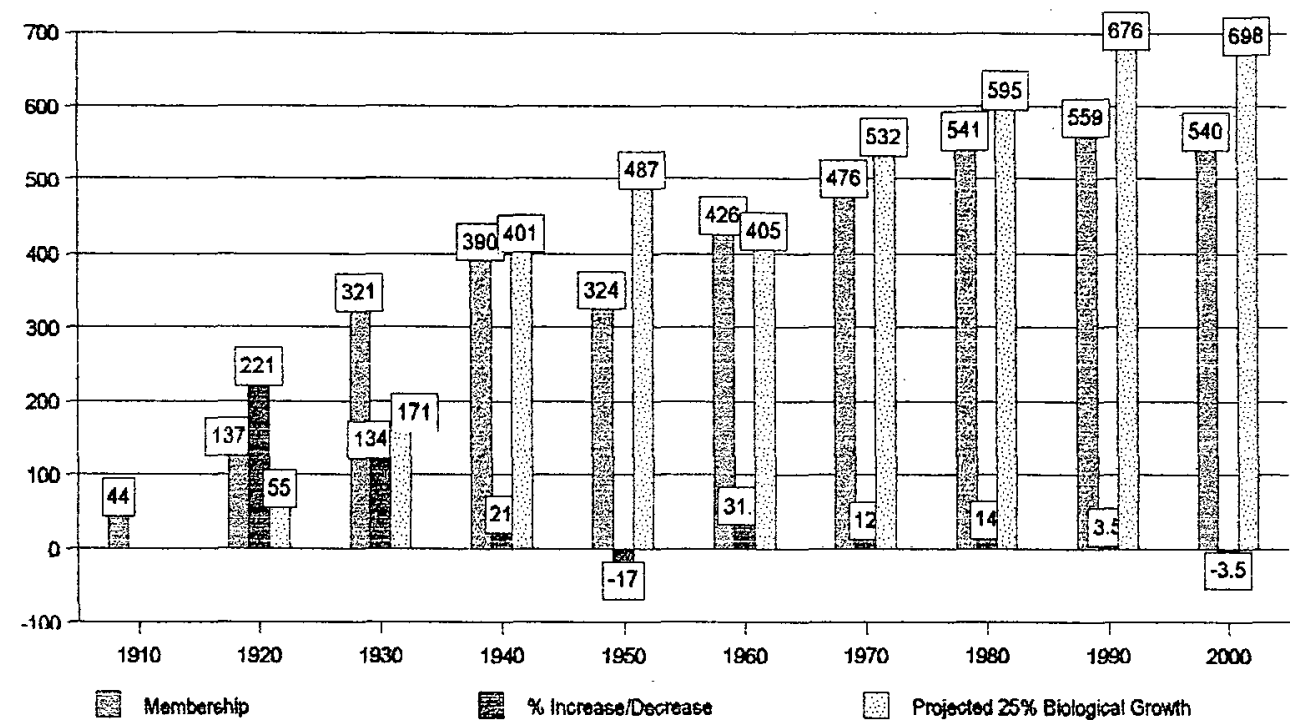

Figure 7. DGR of total membership, 1910-2000.

${ }^{1}$ It should be pointed out, in spite of what has been said, that on the whole the church members were worthy representatives of the Adventist cause, participating faithfully in internal church activities and in charity work such as the Dorcas Society and the Ingathering program, and from many of them godly influence emanated to the society so as to give great honor to God's cause. 


\section{Development within the Iceland Conference}

From the study of the growth figures of the churches (see fig. 7) we see that after a period of rapid decline in growth ${ }^{1}$ there is a short period of growth following the establishment of the secondary school in 1950 . Then the church experiences slight growth until a plateau is reached in the $1980 \mathrm{~s}^{2}$ Then the last decade of the century shows an actual decrease of membership. But the membership records do not tell the whole story. During this period the Iceland Conference operated an impressive program considering its relatively few members and small pastoral workforce: ${ }^{3}$ It ran a publishing house issuing Sabbath School quarterlies and new book titles in Icelandic regularly for church and public consumption and employing a team of full-time, part-time and student colporteurs (especially during the summer months) who covered the whole country with the literature ${ }^{4}$ A store was for a period operated adjacent to the conference headquarters in the center of Reykjavík carrying health food and literature. On the education front there was the boarding school, Hlióardalsskóli, offering 8th-10th-grade education to up to 90 students and then four church schools were in function while the program was at its peak. A very active temperance department ran for some time anti-smoking clinics all over the country and smoking, alcohol and drug prevention promotion in schools. Also

\footnotetext{
${ }^{1}$ A marked decrease in membership $(1946,1947)$ was caused by a campaign to clear the church records of apostatized and inactive members.

${ }^{2}$ If the rule of thumb is applied that $25 \%$ biological growth can be expected as suggested in the Gerber Manual the churches had already failed to live up to those demands in the 1960s (fig. 7). Gerber, 50.

${ }^{3}$ Until 1946 there was only one ordained minister at a time. Then 2 , until 1979, when they became 3 as is the case at the present time. For shorter periods up to 6 ordained ministers served the conference but at times the principal at Hliðardalsskóli was one of them.

${ }^{4}$ Full-time, part-time, and student colporteurs were much more numerous for a few summers in the mid-sixties, reaching a peak of 28 in 1966. Brażrabandid, December 1966, 11.
} 
there was a successful Ingathering campaign every year that reached even the remotest parts of the country, and active Dorcas Societies were operated within the churches. In addition to this a camp meeting for the churches, a separate youth camp, and a Vacation Bible School, which also drew children from the general public, were run yearly.

But it becomes apparent that the church was not evangelistically successful during this period. Public campaigns were held regularly and a Correspondance School operated, but with very limited results. The campaigns were held by local ministers as well as foreign speakers, often provided by the Division. Then in 1988 a special effort was made as a Conference Evangelist was employed, an Icelander, who was to concentrate his efforts on public evangelism. The conference had then translated and was in the process of producing a user-friendly Revelation Seminar especially with the purpose of placing it in the hands of trained lay people who would run it for small groups in homes. As it turned out the Conference Evangelist became the near sole user of the material. His work from 1989-1998 produced some results and a church was reestablished in Hafnarfjörður, a neighboring town to Reykjavík in 1992, with about twenty-five members.

But by the mid-1990s the whole membership of the conference reached a critical point which has affected it in a decisive way. Two events were especially crucial. First, the operation of the boarding school, Hliðardalsskóli, was proving more and more difficult due to a series of contextual factors affecting it. This resulted in fewer applications and then public funding which the school had enjoyed for some years was no longer available. Also the attendance of Adventist students decreased steadily until 
none attended. This, finally leading to the closure of the school in 1995, proved emotionally traumatic for many of the church members as the school was very dear to them and it had also served as a symbol and a venue for the service the church was rendering in society. ${ }^{1}$

Second, three years after the closure of the school a difficulty arose among the workers of the conference which finally brought about the termination of one of the pastors. He consequently decided to establish his own church outside the Adventist denomination while still maintaining an identical doctrinal base, taking with him some of the members of his newly formed church in Hafnarfjörður. This schismatic event may have obstructed the church in its vision and reduced its performance in many areas.

If we look at the membership growth figures for 1993-2003 for the conference as a whole we see in figs. 8 and 9 a steady decline of membership of 0.3 percent $t^{2}$ on average per year, and fig. 10 reveals that the sixty-six newly baptized in this period are almost equally shared between SDA (52\%) and non-SDA (48\%) background.

${ }^{1}$ Five years earlier a new housing facility was built for the Reykjavík church school allowing it to expand its operation to cover grades 1-10. This institution, Suðurhliðarskoli, now the responsibility of all the churches in the Conference, has, after the closure of Hliðardalsskoli and the other church schools, become the only school operated by the church.

${ }^{2}$ Thus the decadal growth rate (DGR) is $-3 \%$. 


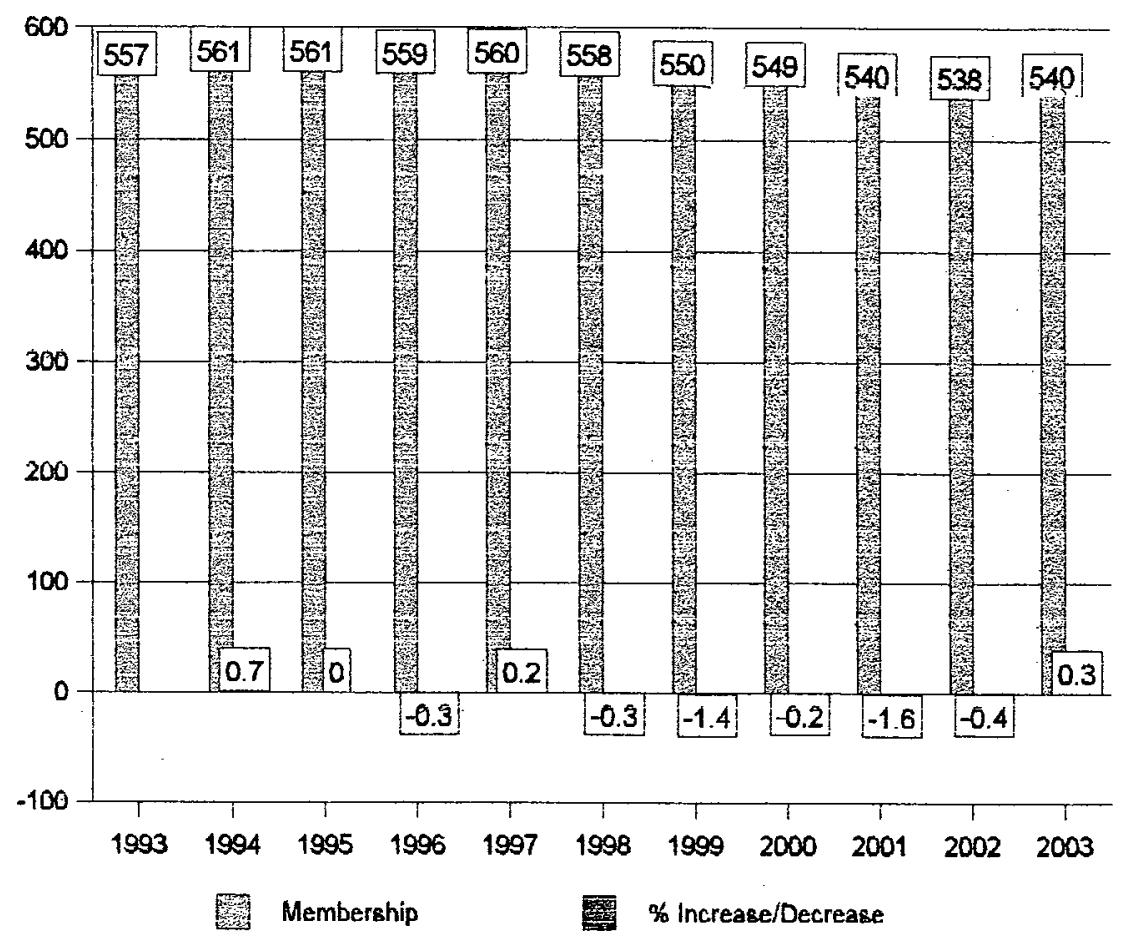

Figure 8. Total membership, 1993-2000.

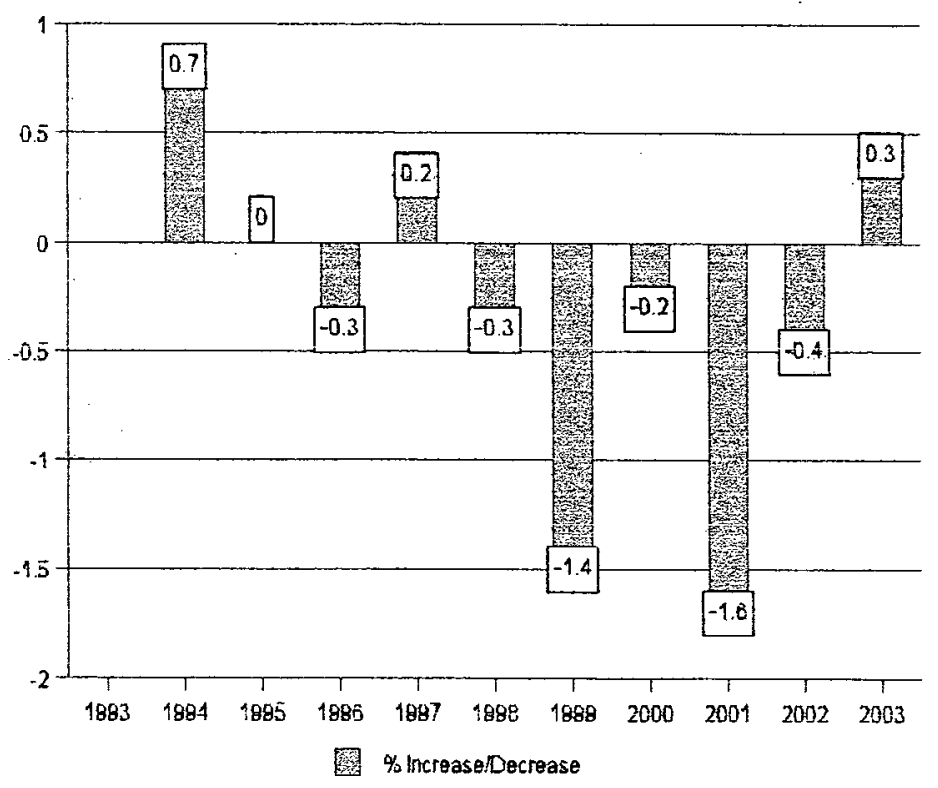

Figure 9. Yearly growth rate of total membership, 1993-2003. 


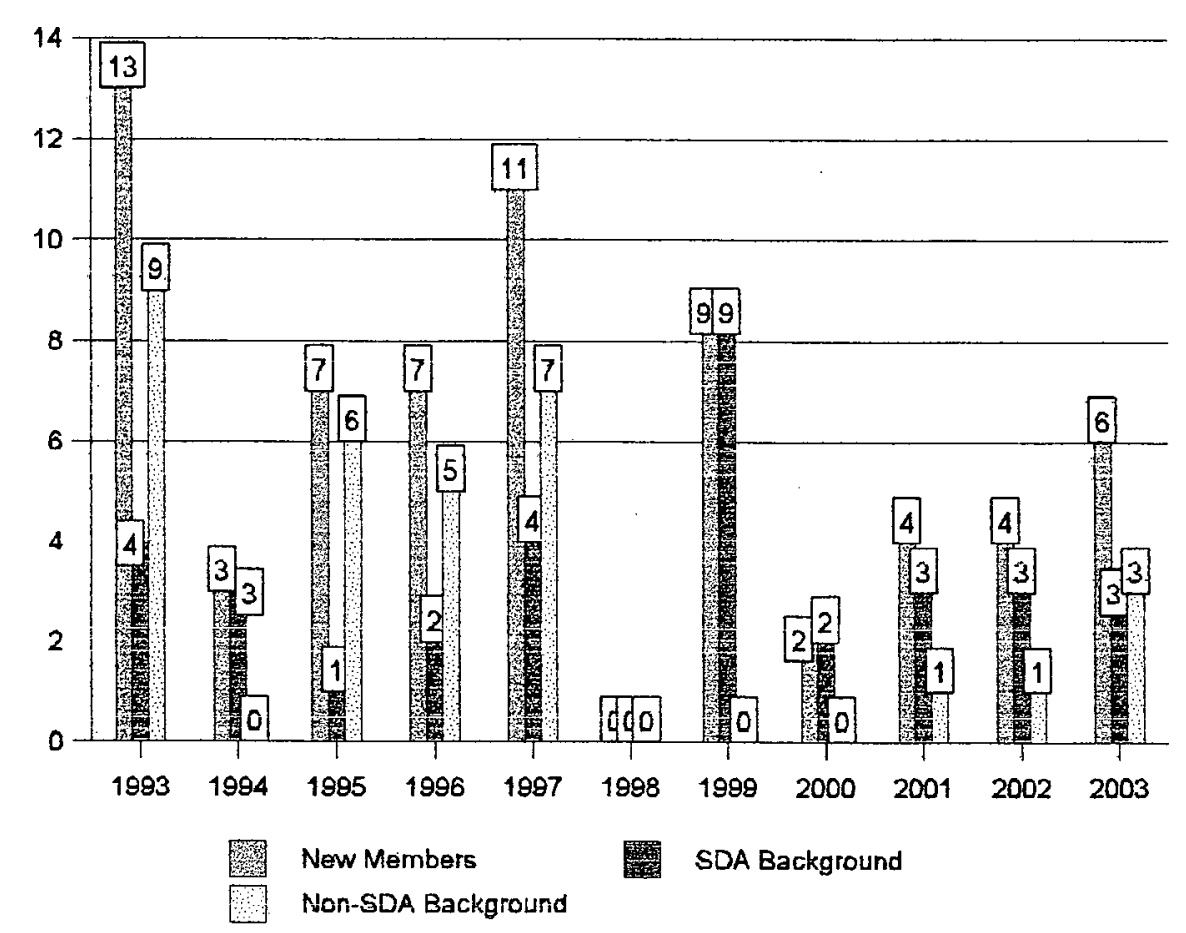

Figure 10. New members, 1993-2003.

\section{Analysis of the Individual Churches}

The Reykjavik church is by far the largest of the churches with over two hundred members on the church books of whom less than one hundred are active. The church was organized in 1906 as the first church in the country. It meets in a church building in the center of Reykjavik, erected 1925. Until recently it ran a church school in a new building which was designed jointly for the school and as an evangelistic center, financed by the conference. ${ }^{1}$ The population of the capital is about 113,000 but a circle of satellite towns within a radius of ten miles are traditionally also served by this church, except for Hafnarfjörður and Garðabær. This increases the population by approximately 37,000 .

\footnotetext{
${ }^{1}$ The school, Suðurhlídarskóli, is now the operational responsibility of all the churches.
} 
Thus half the population of the country resides within the area of this one church. Figs. 11 and 12 show a steady decline in the membership in Reykjavík church for this ten-year period as thirty-one were baptized (twenty from Adventist background) and seven were transferred to the church, while thirty-eight individuals died and fourteen were

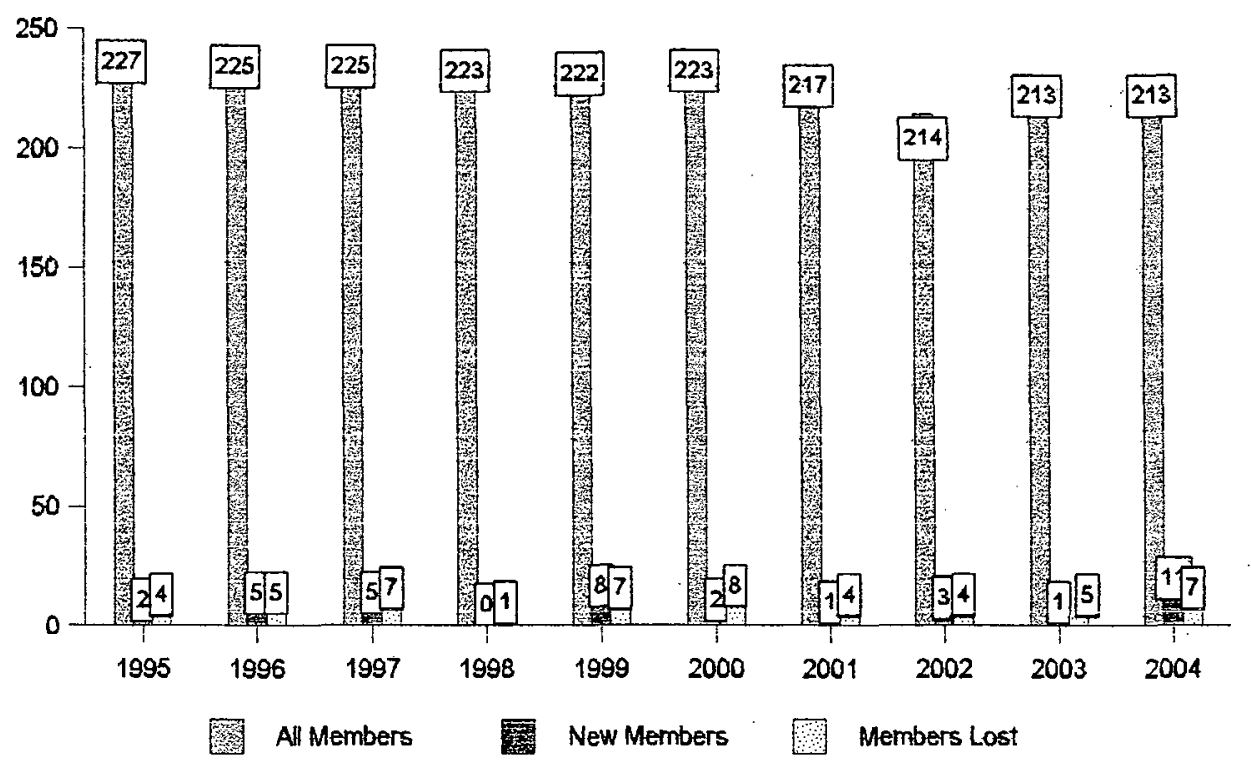

Figure 11. Reykjavik Church - Total membership, 1995-2004.

transferred to other churches, producing a net loss of fifteen people. Thus the DGR for the Reykjavik church for this period is -6.5 percent as shown in fig. 13. The Hafnarfjörður church is the newest church, organized in 1992 after evangelistic meetings were held in the area. Some of its charter members transferred from Reykjavik Church to Hafnarfjörour to assist in getting the church going. The membership is about 60 and regular attendance is also close to that number each Sabbath. It meets in a facility of its own in the township of Hafnarfjörður about ten miles from the Reykjavik Church. Its 


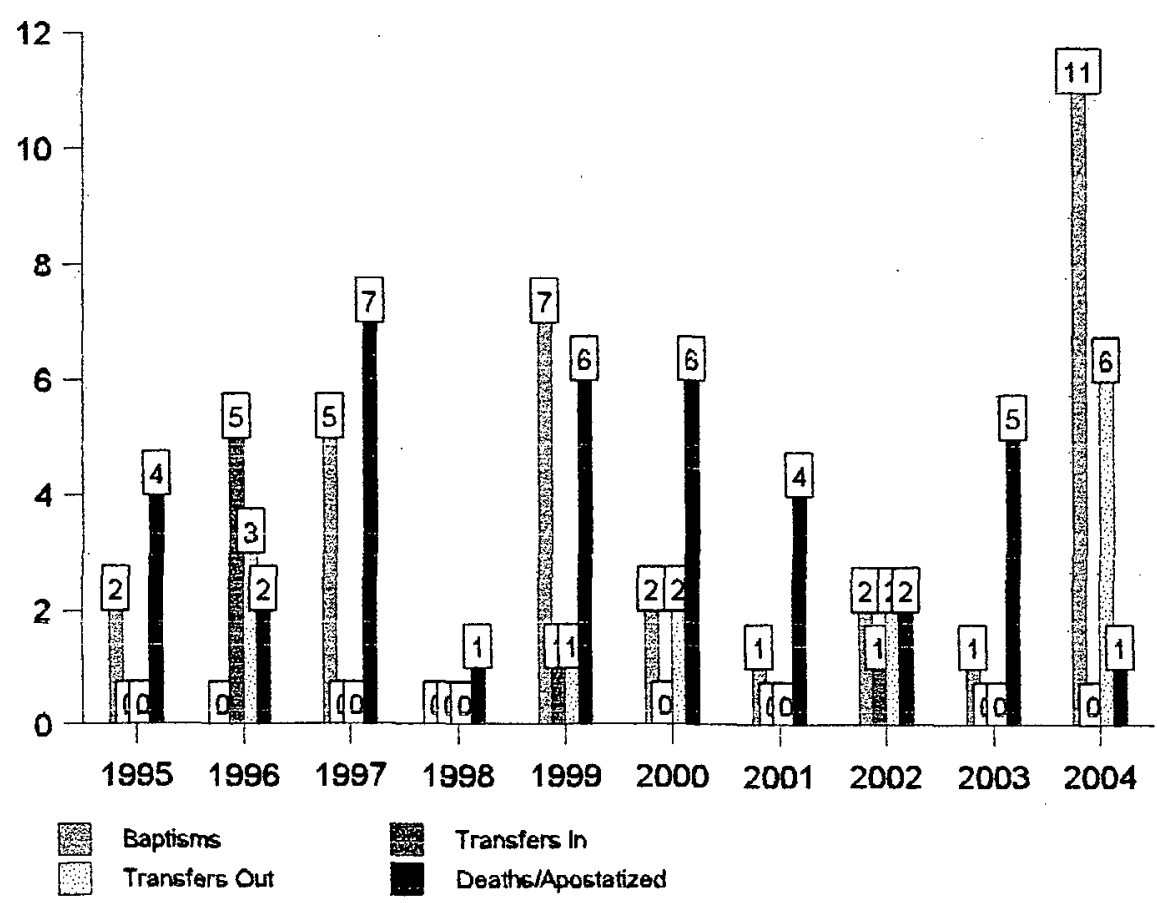

Figure 12. Reykjavik Church - Acquisitions and losses, 19952004.

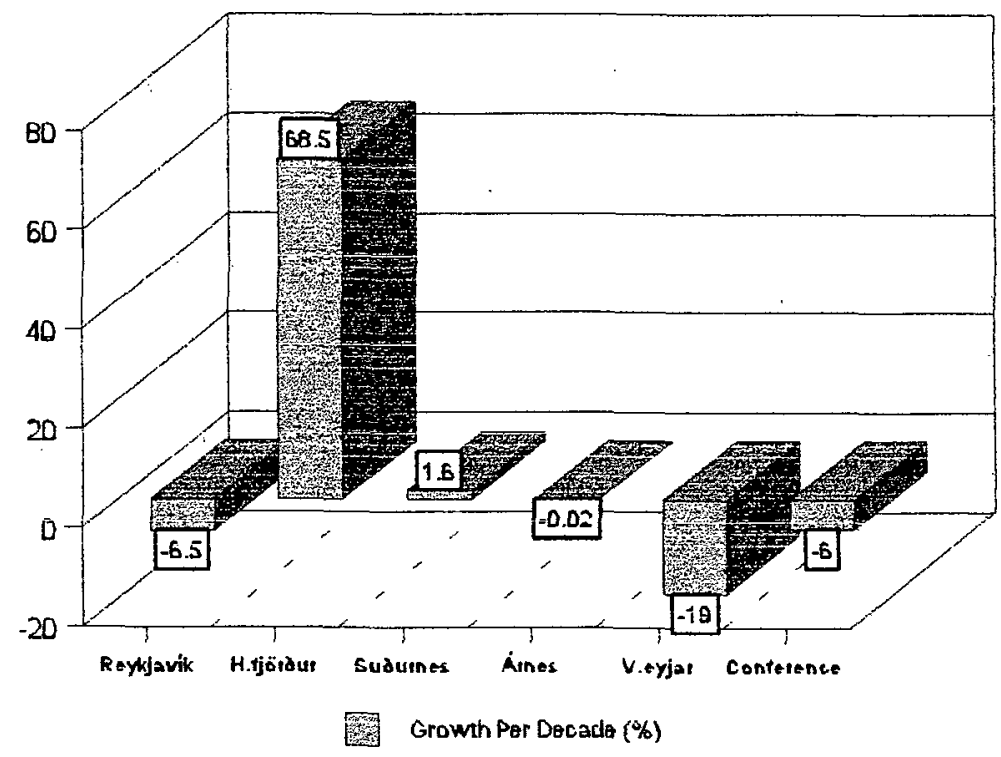

Figure 13. DGR of Icelandic Churches, 1995-2004. 
membership mostly comes from Hafnarfjörður, a town of about 22,000 and Garðabær with 9,000 inhabitants. The fishing industry is strong there as well as other industries and it benefits from close proximity to the capital. It is generally a medium to high income area.

Figs. 14 and 15 show some growth of this church except for the years 1998 and 1999 coinciding with the traumatic events of the dismissal of the pastor of the church mentioned earlier in this chapter. The growth consists of seventeen newly baptized individuals (ten from an Adventist background) and twelve transferred members, nine of whom have come from the Reykjavik church. Only five were lost percent as shown in fig. 13.

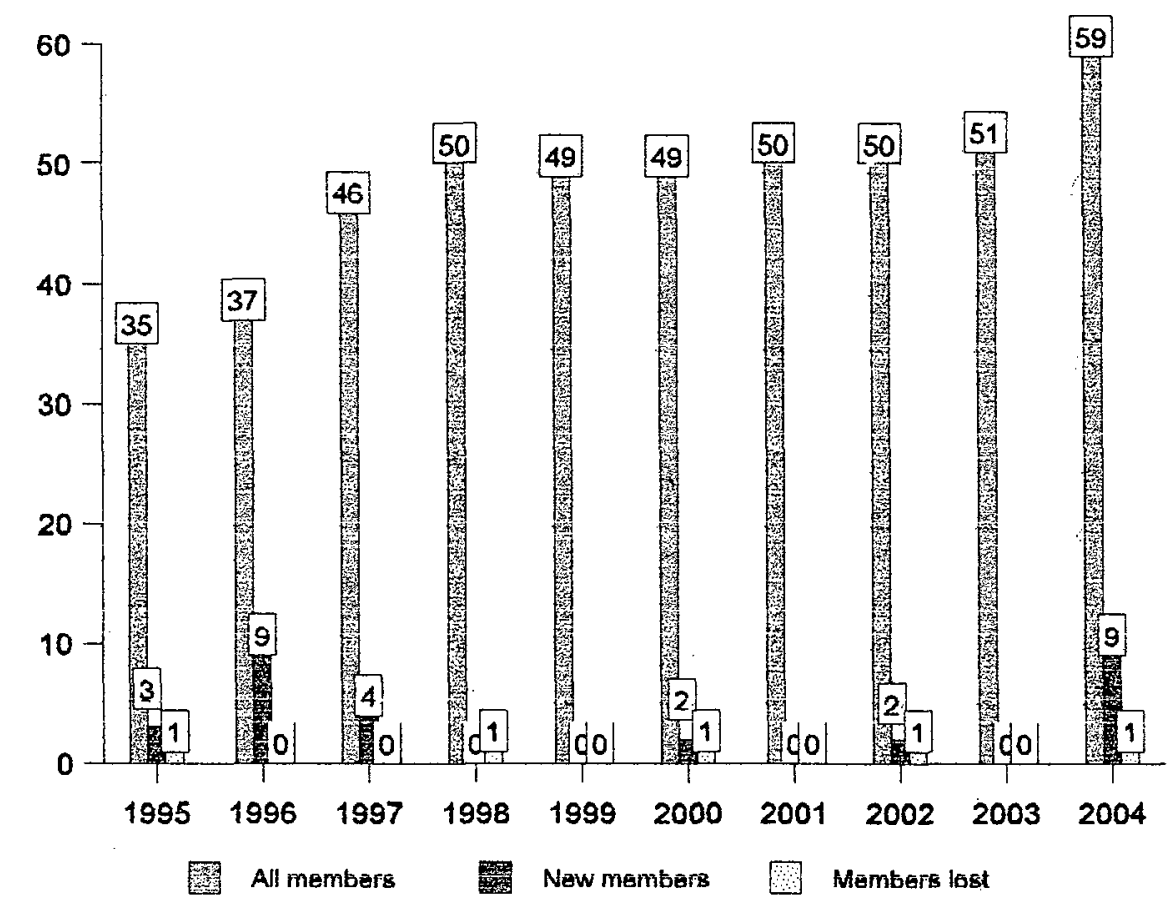

Figure 14. Hafnarfjörður Church - Total membership, 19952004. 


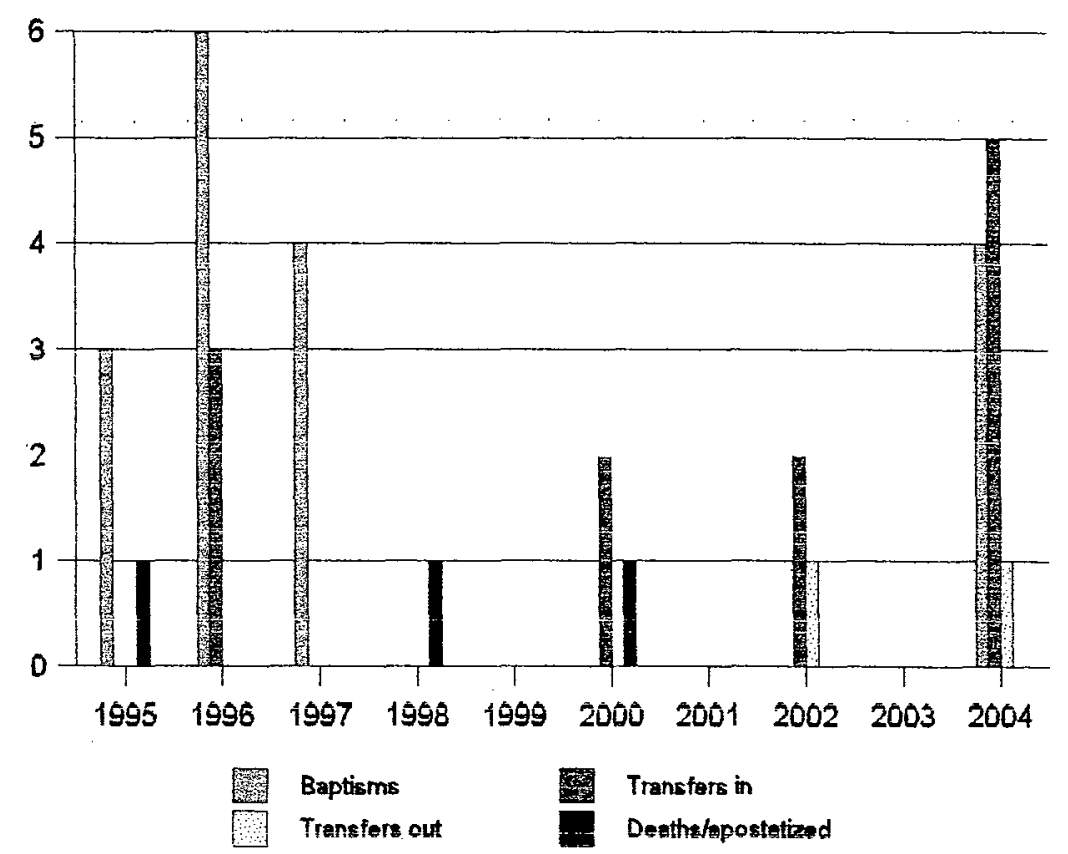

Figure 15. Hafnarfjörour Church - Acquisitions and losses, 1995-2004.

Figs. 16 and 17 reveal a slight growth in the Suðurnes church which is located thirty-five miles away from Reykjavik towards the southwest. Six baptisms have taken place during the period, all of whom were from an Adventist background and one transfer to the church. But six members deceased so the net growth is only one person. This church, which was organized in the 40 s, has sixty some registered members but only one third of these attend regularly. It meets in a church facility of its own in the township of Keflavik but also serves a cluster of small towns within a radius of ten miles (total population 17,000 ) partly sustained by fishing or other industry, partly by jobs provided by the NATO base and the international airport. 


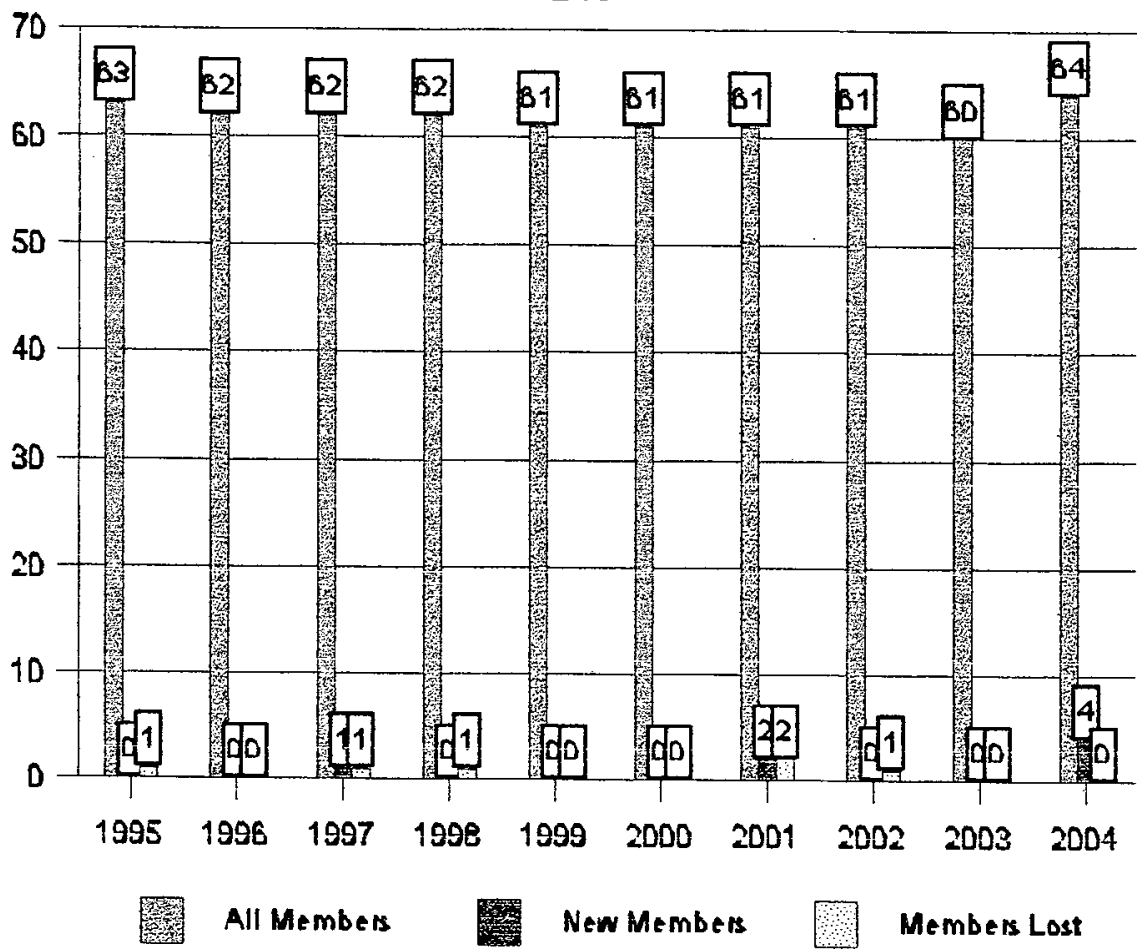

Figure 16. Suðurnes Church -

Total membership, 1995-2004.

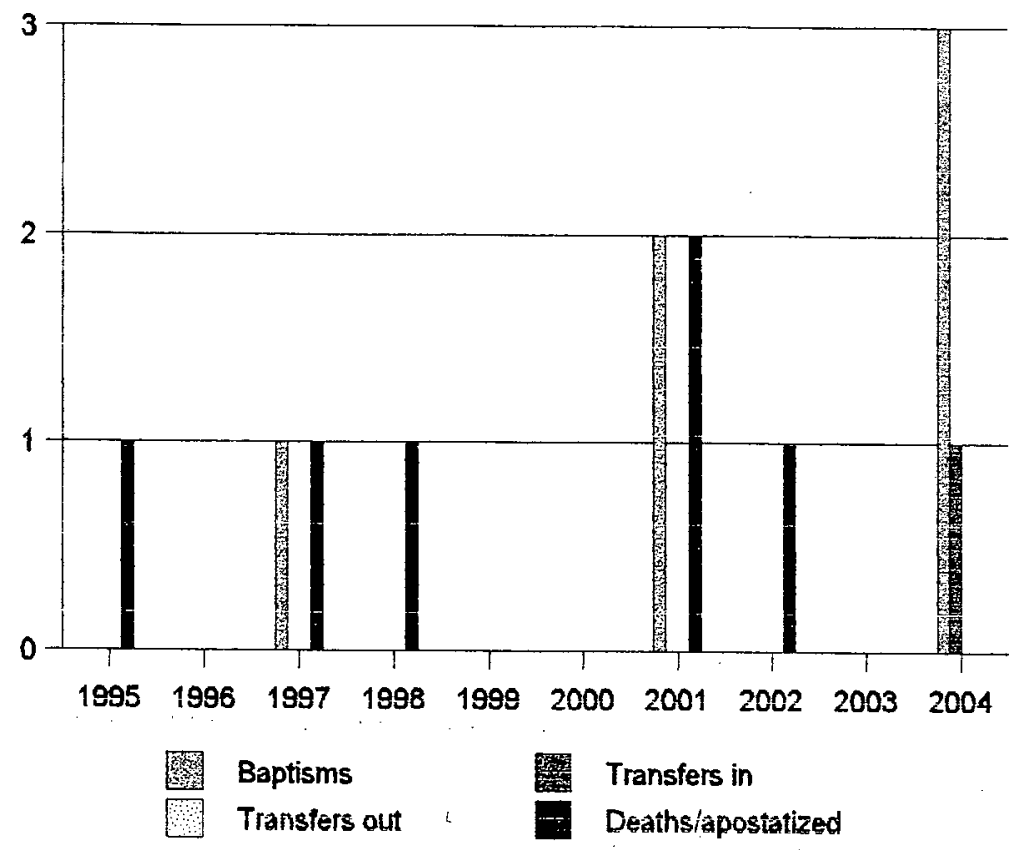

Figure 17. Suðurnes Chureh Acquisitions and losses, 1995-2004. 
The Árnes church is situated about thirty miles from Reykjavik across the mountains towards the south-east. It consists of about sixty members on the books, of whom about 30 attend the church meetings regularly. The church was organized in the 50s especially by people involved in the operation of the boarding school. It meets in a facility of its own in the township of Selfoss which is a 30-minute drive from the former boarding school. ${ }^{1}$ Selfoss has a population of about 5,000 and is surrounded by four other smaller towns within a radius of ten miles (total population of area about $10,000)$. Jobs are generated by food production, small industries or service-oriented enterprises for the surrounding farming community providing stable, moderately high incomes. Many people living in the area commute for work in the capital.

Figs. 18 and 19 tell a very similar story as with Suðurnes church. Four people have joined the church through baptism and transfer but five have died. The Vestmannaeyjar church is located on an island off the south coast of Iceland accessible by a ferry (three hours sailing time from borlákshöfn) or by plane. It was organized in 1924 after outstandingly successful evangelistic campaigns on the island. It was the second largest church for many years with well over 100 members and ran a church school since 1928. But after a volcanic eruption in 1973 when the island had to be evacuated, only a limited number of the members returned and the school was soon closed after that. The present population in the island is 4,200 but the church now counts just over thirty members of whom less than twenty come regularly.

\footnotetext{
${ }^{1}$ The school buildings are now used by the conference or the churches for camp meetings or seminars, or are rented out.
} 


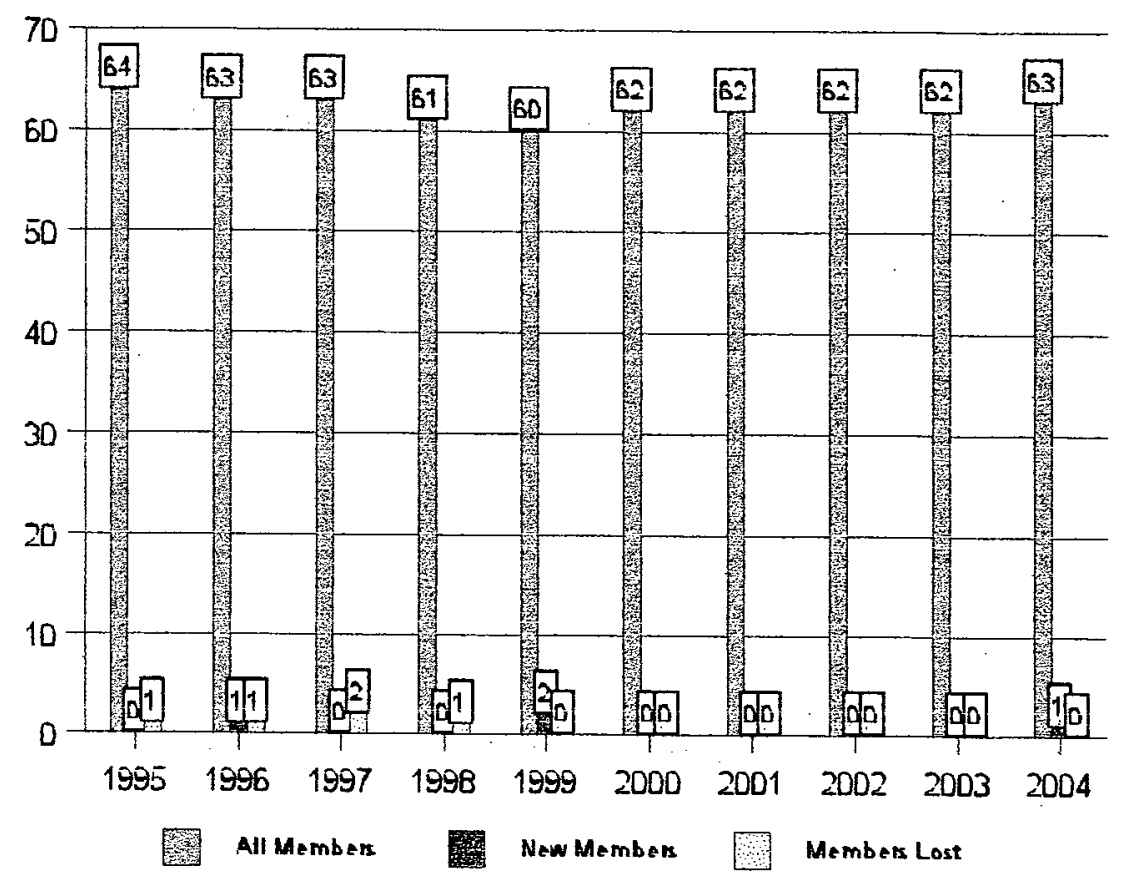

Figure 18. Árnes Church -

Total membership, 1995-2004.

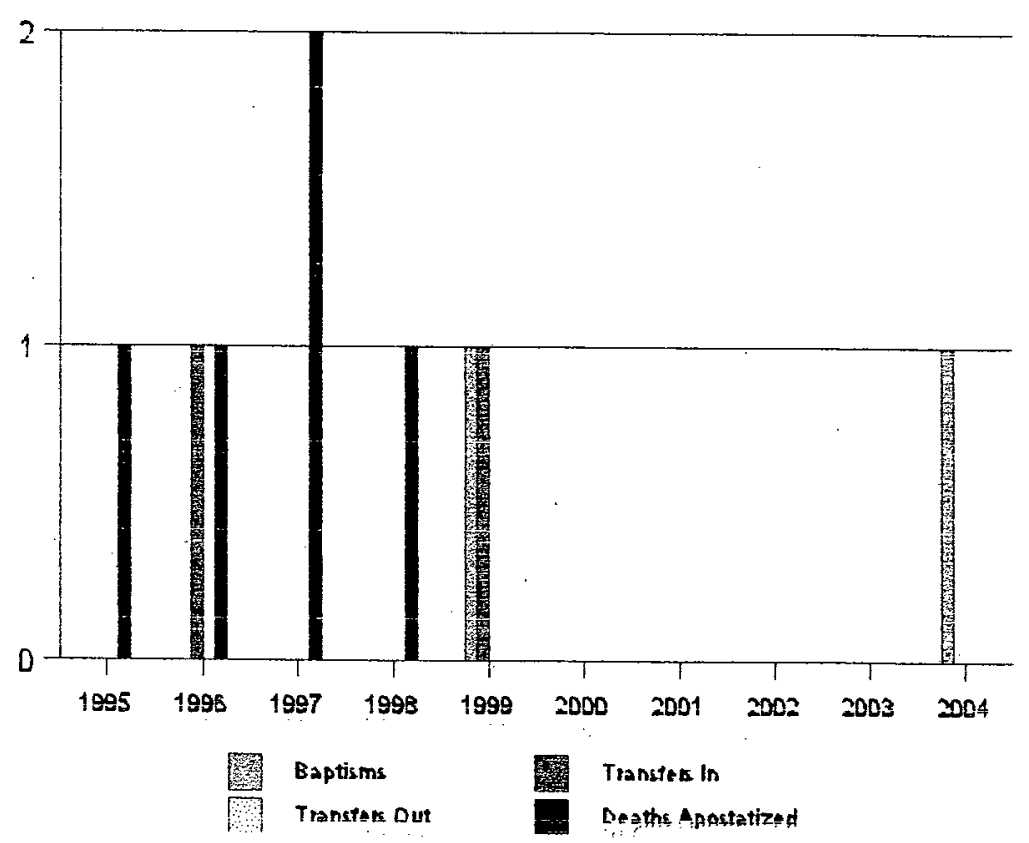

Figure 19. Árnes Church Acquisitions and losses, 1995-2004. 
Figs. 20 and 21 tell a clear story of decline in Vestmannaeyjar. During the period there has been a loss of eight members which means a DGR of -19 (fig. 13).

Finally, the Conference church (figs. 22 and 23) consists mainly of the members

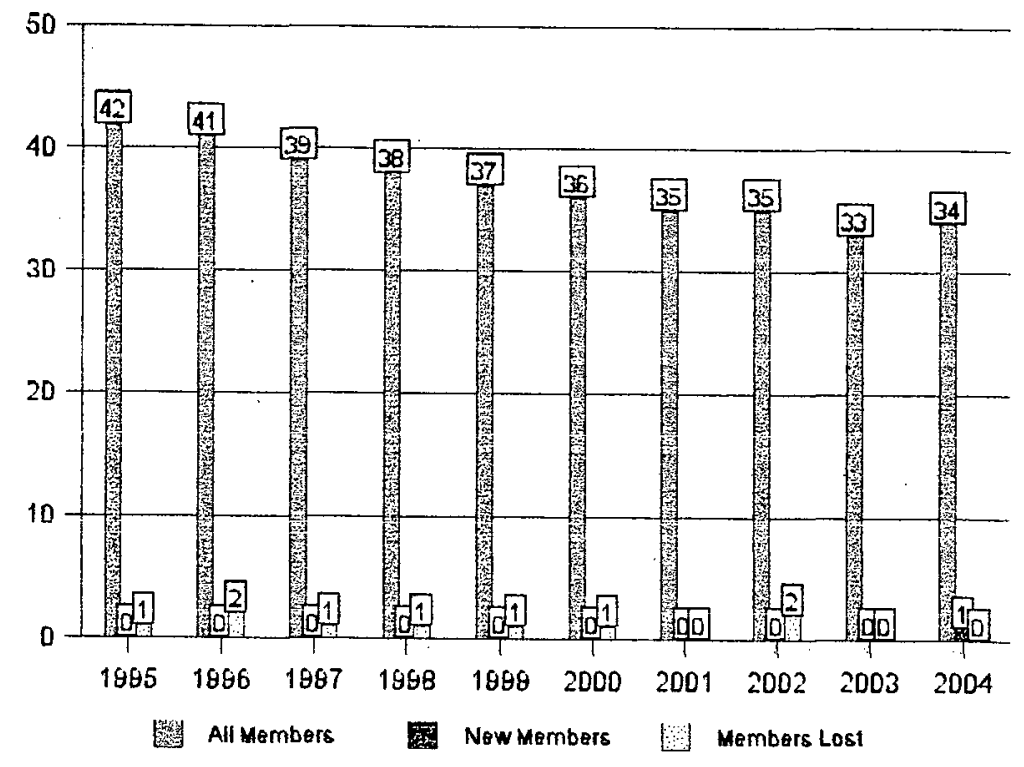

Figure 20. Vestmannaeyjar Church Total membership, 1995-2004. 


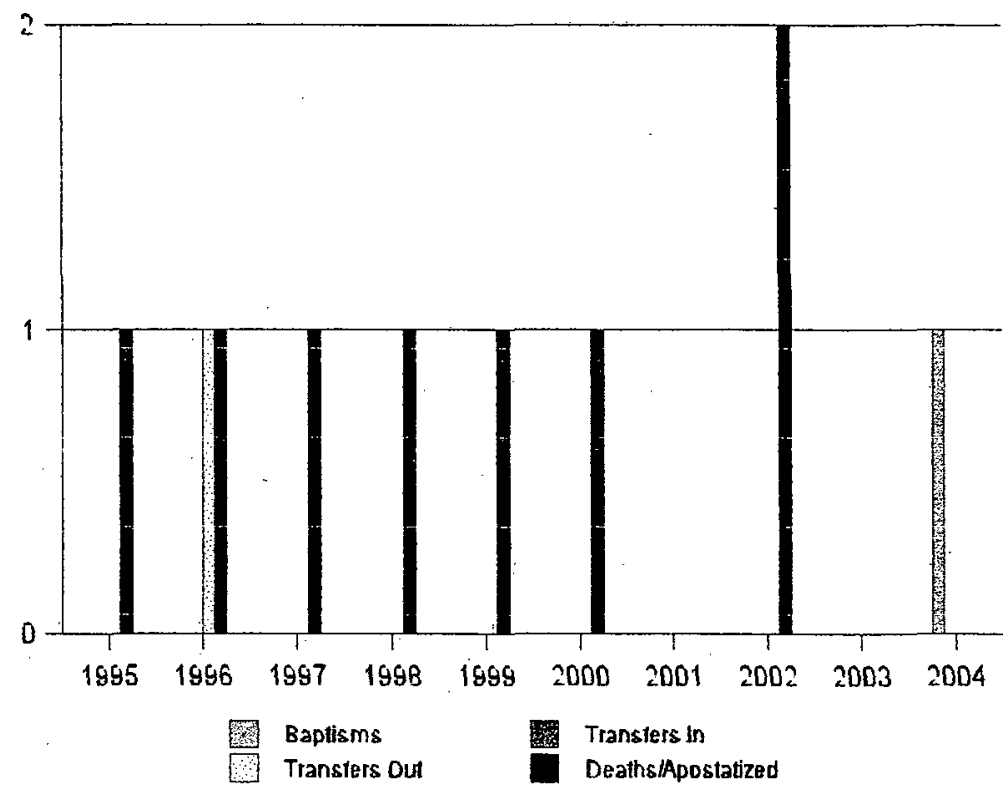

Figure 21. Vestmannaeyjar Church Acquisitions and losses, 1995-2004.

in Akureyri where a company has been formed. Akureyri, the capital of the north of Iceland, is about 300 miles from Reykjavik and has a population of 16,000 with another 4,000 living in neighboring towns and villages. Most of the about 20 members here meet regularly in private homes or a rented hall on Sabbaths. In all, the Conference church has about fifty members registered as is seen in fig. 22 but the number is slowly shrinking as is the case with most of the churches we have observed. 


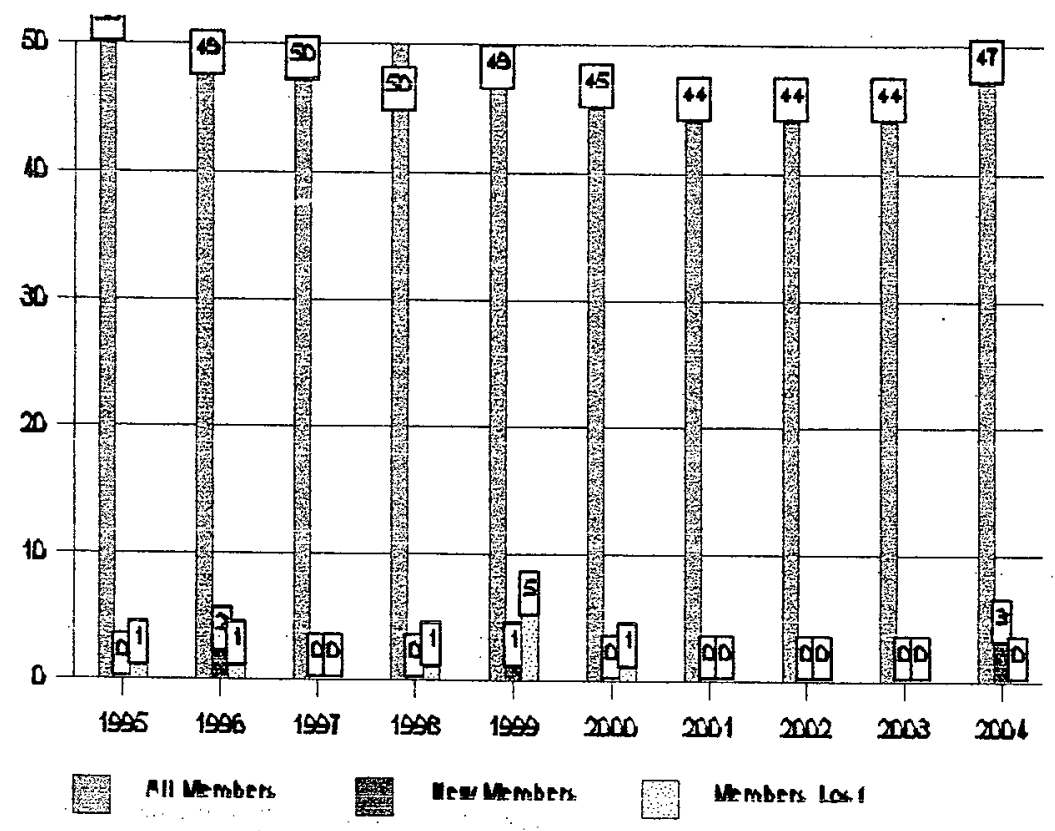

Figure 22. Conference Church -

Total membership, 1995-2004.

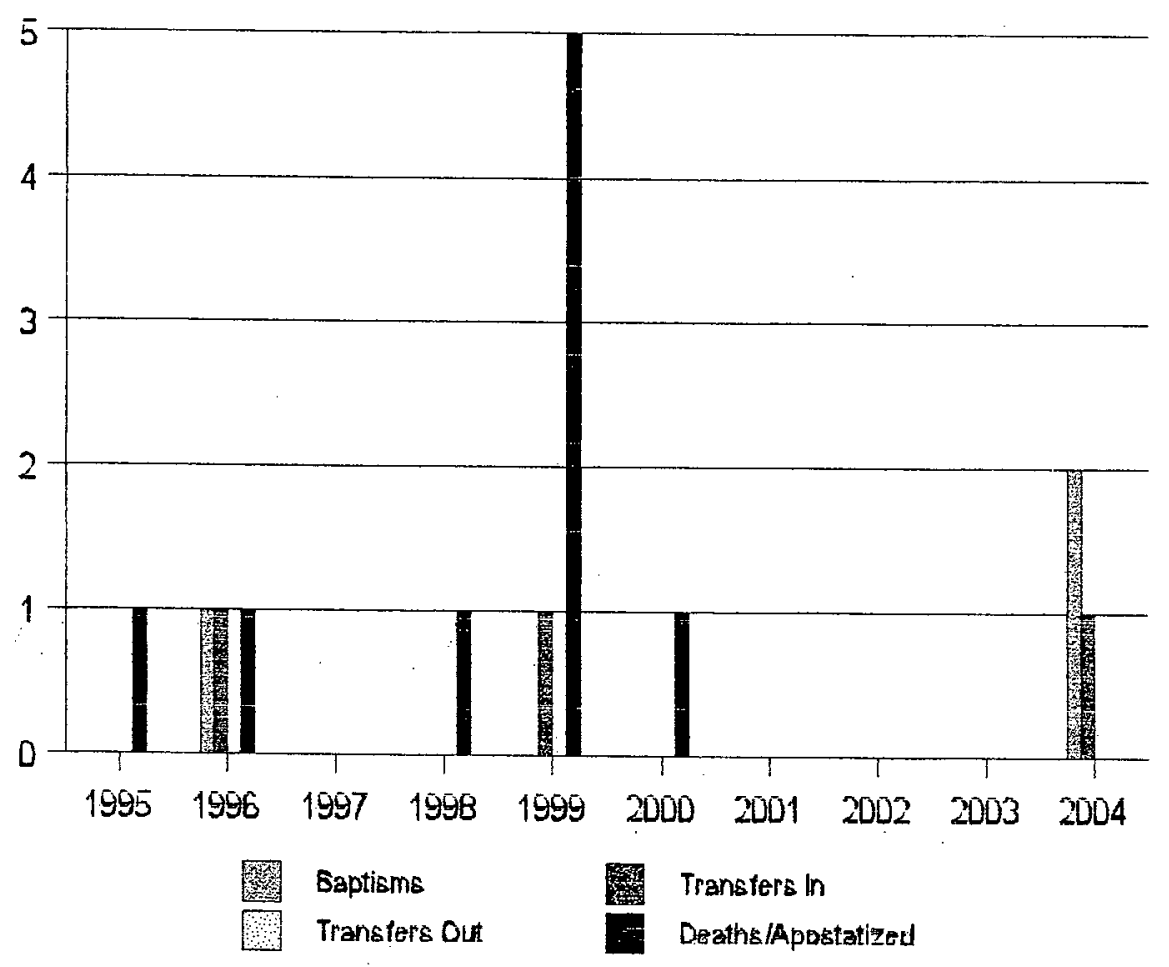

Figure 23. Conference Church Acquisitions and losses, 1995-2004. 
On the whole the picture that emerges of the churches in Iceland is not an encouraging one. There is very little or no growth taking place and some of the churches are in marked decline. There is a significant number of registered members who are not attending church regularly and quite a few never attend, indicating that the numbers we are operating with may be unrealistic. A marked exception is the Hafnarfjörður church where growth is taking place, but on closer examination it becomes clear that most of it is biological and transfer growth (75\%) which leaves much to be desired in the effectiveness of the church in reaching out to the community with its evangelism. All is not gloom and doom though. The churches and the conference are very active, operating an impressive program of church and evangelistic activities and quite a vigorous youth group operates in the Reykjavik and Hafnarfjörour churches. But from this study the sobering thought presents itself that without a dramatic turnabout in the growth pattern of some of these churches, they will very likely soon start to decline at a much more rapid pace and thus in a few years no longer be operational.

\section{Summary}

The Adventist message entered Iceland providentially at the turn of the twentieth century when the cultural and spiritual climate was uniquely open to the message. We have seen in this chapter that the mission would not have been so successful had it arrived a few years earlier or just a decade later. The church's representatives immediately made an impact on the religious scene in the country, and after two decades they could state that every household in the country had been exposed to the third angel's message in the form of literature or heard it preached, or both. The church grew very 
rapidly to begin with, at the rate of over 200 percent DGR, ${ }^{2}$ but as receptivity in society changed and, in the words of McGavran, "the first source of growth was no longer available ... the church failed to seek another." Thus as public evangelism ceased to yield results, the church settled for minimal growth while not recognizing that a lack of trained local leadership and the exercising of spiritual gifts such as that of evangelism within the local congregations was arresting its growth possibilities and its ability to reproduce itself.

We have seen that in spite of much activity by the Iceland Conference at the middle of the last century with different kinds of outreach programs such as literature evangelism, Bible correspondence courses, public evangelism, and school work, growth of the churches decreased and became minimal. And as we have had a closer look at the present state of the six churches in the Iceland Conference, we have found them, with one exception, to be stagnant or declining numerically.

In view of the poorly functioning local Adventist congregations in Iceland Conference with respect to local leadership and lay evangelism, a revitalization of their vision is of paramount importance. It is also vital for the church of today and tomorrow not to repeat the mistake of attracting people to the church mainly on the basis of individualistic conviction of doctrine, but that they become thoroughly rooted in a wellfunctioning church as the body of Christ, where they receive instruction and become a

${ }^{2}$ A game with numbers doesn't grow the church but for the sake of amusement it can be included that had the church grown by on average $150 \%$ DGR every decade since 1910 half the Icelandic population would have become church members by 2000 . While had it grown by $200 \%$ DGR like in the beginning of the Icelandic mission the whole nation would have become Adventists by 1990 !

${ }^{3}$ McGavran, Understanding Church Growth, 99. 
part of a caring, reproductive church organism deeply concerned and well equipped to deal with relational issues and able to connect with the community within which they exist. In other words, to be a truly apostolic congregation. I will now seek to outline a program where these ideals are pursued. 


\section{CHAPTER V}

\section{A MODEL STRATEGY FOR GROWTH OF THE ADVENTIST CHURCHES IN ICELAND}

\section{Introduction}

The Adventist Church in Iceland has developed along the lines of many other Adventist churches in the Western hemisphere. From the beginning the progress of the Adventist mission in the county was based on powerful prophetic preaching. The role of the members in the growth process was to a great extent that of being regular in attendance of meetings and assisting the pastor/evangelist in evangelism where he was virtually a sole player. The program of the churches has not changed much through the years except as evangelism has ceased to be a prominent feature in the program due to difficulties in obtaining results. Today the churches struggle to maintain status quo and are in a varied degree dependant on a pastor for their nurture. The churches' concept of purpose has to a large extent become the narrow idea of remaining able to maintain services for themselves.

It is the purpose of this chapter, on the basis of the foregoing analysis of the present situation, to suggest a strategy of revitalization and growth in the churches in Iceland. The aim of this strategy is a revisioning of the life of the churches in all aspects of their program, allowing for natural growth in quality as well as numerically.

After describing a biblical vision to guide the suggested revitalization, I will 
attempt to outline a strategy of revitalization in a twofold way: First, an initiation of gradual change will be introduced which aims at a spiritual revival through the establishment of small groups and a gradual shift towards a lay-led church with an emphasis on a lay training program. Second, the Natural Church Development (NCD) concept of church advancement will be introduced, its relevance to the case under treatment will be assessed, and an application will be made to the concrete situation of the churches of the biotic principles advocated by NCD. It is suggested that the NCD concept of quality growth leads to quantity growth, and its methods of assessment govern the future long-term program of the churches.

\section{The Biblical Vision}

An Emphasis on Mission and the Engagement of the Laity

A revitalization of the churches will involve a change of ingrained conceptions which does not come easy. Antoine de Saint Exypery has said: "If you want to build a ship, don't summon people to buy wood, prepare tools, distribute jobs, and organize the work, rather teach people the longing for the wide, boundless oceans."' The inference is that people are motivated by vision to a greater degree than by need. An indispensable tool in our hands to cast a vision for change is a clear biblical foundation. Attention must be given to helping the church as a whole to discover from a study of the New Testament that the gospel proclamation was the raison d'etre of the early church rather than mere self-preservation, that its vision was that of relentless missionary conquests. Furthermore, the operational model of the lay ministry paradigm must become clear to the

\footnotetext{
'Quoted in Christian Schwarz and Christoph Schalk, Implementation Guide to Natural Church Development (Carol Stream, IL: ChurchSmart Resources, 1998), 26.
} 
church from a study of the text and also the fact that the distinction that traditionally is made in the church between clergy and laity is unbiblical (see 1 Pet 2:9). Hendrik Kraemer states that all lay ministry "will ultimately rail if it has no lasting and serious theological foundation. It will appear in the future a mere temporary effervescence or a passing erruption [sic] of activism, without real backbone, if it is not undergirded by a well-thought-out theology of the laity on a biblical basis, which becomes a natural and inalienable part of that new-common understanding of the church."

This must be the strategy of change in the churches: it must be perceived as a return to the biblical model, firmly undergirded by biblical theology.

\section{Church Growth in the Adventist Context}

We have already studied the motivation for Adventists to be God's messengers in the final hour of earth's history as rising from the commission of Christ to his followers in Matt 28:16-20 to extend his mission to all the world, as well as from the urgency of the second coming expressed in Matt 24:14, the challenge of "preaching ... Christ's message to all the nations in order to hasten the advent of our Lord." ${ }^{\circ 2}$ Thus the Adventist proclamation of the "good news" of salvation in Jesus Christ becomes simultaneously the announcement of the "good news" of the imminent return of the Redeemer. ${ }^{3}$ But we have found the key to full understanding of the Adventist mission to be in Rev 14 where the task of preaching to all the world, that of discipling, and the concept of the impending

'Hendrik Kraemer, A Theology of the Laity (Philadelphia: Westminster Press, 1958), 46, quoted in Win Arn, ed., The Pastor's Church Growth Handbook (Pasadena, CA: Church Growth Press, 1979), 20. 57.

${ }^{2}$ Russell Burrill, "Recovering an Adventist Approach to Life and Mission of the Local Church,"

$$
{ }^{3} \text { Ibid. }
$$


consummation of the world's history are presented in a striking and compelling way. A strategy of church growth, then, in the Adventist context must derive its meaning from the above passages.

\section{An Adventist Mission by an Apostolic Church}

But as the successors of Christ's disciples the Adventist church today is called to live out the whole content of its truly Christian mission as exemplified in the apostolic church of the first disciples (see Acts 2:42-47 and other passages), based on their experience with the Lord himself. ${ }^{1}$

In proclaiming the "everlasting gospel" of salvation by faith in the merits and intercession of Jesus Christ in a unique apocalyptic setting, the Adventist Church seeks to reach all people and extend an invitation to all human beings to avail themselves of this last invitation of grace offered by God to a dying world. But the ensuing internal growth, restoration of the image of God, and complete victory over sin through Christ's victorious power, are at the core of the gospel project. "The Adventist message of the gospel of grace, followed by discipleship that restores people to the image of God through cleaning up the mind, healthful living, and Sabbath keeping to build a relationship with Christ, leads into full discipleship."”

Hence the internal, quality growth of the community of faith in the context of the

\footnotetext{
${ }^{1}$ George Hunter sums up in ten points what he finds as essential elements in the program of a church that claims faithfulness to the "apostolic" heritage: (1) The rooting of believers in Scripture. (2) Disciplined earnestness in prayer. (3) Understanding, liking, and having compassion for lost people. (4) Obedience to the Great Commission. (5) A vision for what people, as disciples, can become. (6) An adapting in music, language, and style to the target population. (7) The involvement of all in small group ministry. (8) The engagement of all members within their spiritual giftedness. (9) Provision of regular pastoral care. (10) The engagement in multiple ministries to non-Christian people. George G. Hunter III, Church for the Unchurched (Nashville, TN: Abingdon Press, 1996), 29-34.

${ }^{2}$ Burrill, "Recovering an Adventist Approach to Life and Mission of the Local Church," 74.
} 
motivating, compelling urgency of the soon returning Lord, and the power of the Holy Spirit, is the source which in turn supplies the outer, quantitative growth of the project with its means of sustenance and increase.

Thus Adventist church growth connotes growing churches of increased holiness and vitality, exhibiting heightened effectiveness and an active process of becoming what they are called to be: a modern reproduction of the apostolic church, a redemptive and nurturing community with emphasis on reproduction and growth in quality in church life, and on being an instrument in carrying out a witness within their own community. But this still involves, on behalf of the church, an active, continuous search and confirmation for its exact nature, purpose, and mission in the present, and a search for the appropriate articulation of the message for the present generation within its context.

\section{The Interactive Method of Presenting the Gospel}

The church has been entrusted with the administering of the gospel in the world. It must do so according to the incarnational principles of Christ's own ministry on this earth as he took on himself "the very nature of a servant, being made in human likeness" (Phil 2:7 NIV), and as exhibited in the ministry of Paul, who strove towards "becoming all things to all men" (1 Cor 9:22). According to this principle the early church during the Jerusalem council (see Acts 15) sought to distill the distinctly Christian view of ultimate reality from outer culturally conditioned forms which are negotiable. The authentic presentation of the gospel calls thus for a constant search for a dynamic application of eternal truth in a changing world.

The church can never be content with repeating the methods of presenting the everlasting gospel inherited from earlier generations but must itself mine it from the 
sources available. Albert Outler has described the interactive method advocated by Wesley in determining God's truth for the present from Scripture, reason, tradition, and experience under the term the Wesleyan quadrilateral. ${ }^{1}$ This approach may have inspired the Adventist pioneers in their quest for present truth. In the same tradition George G. Hunter comments: "We can "know" the Truth primary from God's self-revelation to us, and also from reasonable thought, reflection upon our experiences, and from the cumulative experience and reflection of the faith community."

As Adventists today we must constantly apply these sources, coupled with and immersed in the inspired counsel of Ellen G. White, and thus in an interactive way apply the body of truth available to us to the present under the indwelling influence of the Holy Spirit. In this way, in the words of Jon Dybdahl, we must "undertake the imperative task of creating and articulating a clear, positive vision of our mission."

The challenge presented to the church to give a relevant and authentic witness may never have been greater than at present when the world appears to be in the midst of transition entering a new phase in history, the age of postmodernity, characterized by a mind-set that tends to deny universal, objective truth, but, in a pragmatic way, sees truth rather in that which facilitates the well-being of the community in which one participates. ${ }^{4}$ Being successful in meeting these requirements the church may just be able

'Albert C. Outler, "The Wesleyan Quadrilateral-In John Wesley," in Thomas A. Langford, ed., Doctrine and Theology in the United Methodist Church, ed. Thomas Langford (Nashville: Kingswood Books-Abingdon Press, 1991), 75-88.

${ }^{2}$ Hunter, Church for the Unchurched, 64.

${ }^{3}$ Dybdahl, 31 .

${ }^{4}$ Grenz, A Primer on Postmodernism, 8. 
to gain a hearing in the postmodern market place to which it has not been accustomed during the reign of the modern mentality and become recognized as "relevant to our entire society ... noi only to the heart but to the mind as well."

\section{Strategic Approach-Natural Church Development}

\section{International Church Survey}

The proposed basic church growth strategy for the work among the above churches is that of the Natural Church Development which is spearheaded by Christian A. Schwarz. For over ten years he was engaged in an international church survey among 1,000 churches in 32 countries on all five continents. Robert E. Logan, who writes the introduction to Schwarz's recent book where he introduces his findings, rates this survey as "the most extensive, statistically valid, world wide church growth research project ever conducted." The aim of this massive undertaking was to empirically determine which factors actually lead to church growth and thus are universal church growth principles as opposed to factors which do not qualify as such. The strategy of the Natural Church Development program is based on the findings of this survey.

\section{The "All by Itself" Principle}

The main thesis of the approach is that by knowing and becoming consistent with the biotic laws governing living organisms in all of God's nature, and thus also pertaining to the life of the church, the body of Christ, the church will release its growth potential in accordance with God's intentions. In other words, the church which functions in a 345 .

'Diogenes Allen, “The End of the Modern World," Christian Scholar's Review 22, no. 4 (1993):

${ }^{2}$ Schwarz, Natural Church Development, 1. 
healthy way will experience numerical growth.

In his analysis, Schwarz pinpoints which dynamic spiritual principles produce growth when they are allowed to function in the church, pointing out many parallels from nature (hence Natural Church Development), equating the powers at work in nature with the powers of the Holy Spirit at work in the church. He finds that the discovery of these natural laws is encouraged by Christ (Matt 6:28).

Schwarz sees the only lasting, true approach to church growth being that of working with the natural powers to obtain growth. To take a comparison with the agricultural world, one can obtain results for a time by forcing nature, but finally this leads to bankruptcy of natural productivity and an ecological disaster as nature is misused. This Schwarz would call the technocratic approach to growth. Opposed to this is the natural growth approach which can be accomplished by discovering the principles governing natural growth processes, which Schwarz calls the biotic principles, or principles of life.

By discovering and adhering to these, the grower unites his efforts with the vitally important and potent growth powers inherent in nature as nature provides for the increase "all by itself."

\section{The Eight Quality Characteristics}

Schwarz and his associates then proceeded in their analysis of churches to focus on the quality aspect of church development, an aspect which always has been regarded somewhat nebulous and unmeasurable, and they were able to show a direct relationship between the qualitative growth of the church and its numerical growth. The great contribution of the survey and its ensuing analysis is this successful construction of a 
valid evaluating instrument and quality index applicable to churches using the survey data as a reference.

By careful analysis of the survey results Schwarz and his coworkers feel they have been able to deduct eight quality characteristics which are foundational for the growth of the church, which are the following: Empowering leadership, Gift-oriented ministry, Passionate spirituality, Functional structures, Inspiring worship services, Holistic small groups, Need-oriented evangelism, and Loving relationships.

The Minimum Factor and the Church Profile

On the basis of the above characteristics Schwarz has been able, according to his careful evaluation, to come up with a quality index value (the 65 -hypothesis), above which quantitative growth will always happen within the church. He also points out that what most effectively hinders the growth of a church is the quality characteristic in which the church scores the.lowest value. This he calls the minimum factor, and the minimum strategy is the wise procedure of the particular church to concentrate its efforts on raising its particular minimum factor at any time. The strategy of a church which participates in the NCD program is then, by conducting a survey in the church, to produce a church profile which reveals the performance of the church in the different quality characteristics and determines the minimum factor.

\section{The Biotic Principles}

The key to the healthy state of each of the quality characteristics is to discover and work in accordance with the principles of nature, thus releasing the growth potential. These Schwarz has demonstrated in his six biotic principles which are the following: 
1. Interdependence, stating that the way the individual parts are integrated into a whole system is more important than the parts themselves.

2. Multiplication, asserting that every living organism grows and multiplies uniil it has reached its natural limits of growth.

3. Energy transformation, promoting the idea of utilizing existing forces and energies-even hostile ones-as they are turned in the desired direction through minute steering engines.

4. Multi-usage, stating that energy spent must not only affect the object intended but also indirectly have effect on the energy source, thus channeling the energy a full cycle to prevent waste.

5. Symbiosis, which is the intimate working together of dissimilar functional units in a mutually beneficial relationship.

6. Functionality, referring to the ability of a functional unit to produce results or fruits.

\section{Spiritualizing and Technocratic Paradigms}

Working according to these principles in raising and developing churches presents a whole new outlook, a new paradigm, a new way of thinking. This means purposefully avoiding the technocratic way of thinking which disregards the natural growth mechanisms at work in the church, disproportionately elevating the institutional side of the church program. But Schwarz warns against another ditch in the spiritualistic way of thinking which seeks rightly to emphasize the spiritual, life-giving aspect, but does it by disregarding the laws of nature.

The middle of the road aspect, Schwarz points out, is the healthy interaction of the 
two poles of the static and the dynamic, the static referring to the technical, man-made structure of the church and the dynamic the organic, living potential in the church. A healthy interrelationship between these poles is conducive to the free function of the life principle of self-organization which characterizes life in nature. The technocratic approach tends to disregard the dynamic pole's potential to produce the life-giving power. It tends to see the structures of the church as the totality of the church program. On the other hand the spiritualistic approach denounces the static pole as unspiritual, even evil (a dualistic attitude) and does not see light in growth principles presented in nature and in God's world, as they feel this is a materialistic, unspiritual sidetrack.

\section{The Ten Action Steps}

Finally, Schwarz suggests ten action steps which he sees as necessary to put these principles into action. They are: Start the process of growth by (1) building spiritual momentum, then (2) determine the present minimum factor among the quality characteristics of the church by conducting a church survey, then (3) set qualitative goals to increase the minimum factor, (4) analyze the church community and the thinking pattern of the leadership to identify present obstacle to further progress, (5) apply biotic principles in reaching decisions and finding solutions, (6) exercise your strengths (the maximum factors), (7) utilize biotic tools, (8) monitor effectiveness by administering another church survey, (9) then address your new minimum factor, and (10) multiply your church.

Applicability to the Present Situation

The NCD program exhibits some obvious strengths: First, it is built on the 
foundation of a massive survey done in churches all over the world and in its particular emphasis on applying the divine principles of natural growth. Its operational method can be described in the words of Logan and Clegg' as not that of seeking to "invent a future" for the church "but to discover how God is already working" and in this way unite human forces with divine in accomplishing true success in the operation of the church. Second, the insistence of the NCD program on constant and realistic evaluation of success of the church in accomplishing its goals of spiritual nurture and growth and organizational efficiency leading to numerical increase makes it adaptable and appealing to different cultural settings. Finally, the program appeals to the popular attitude of today which is result oriented rather than motivated by traditions, external authority and formality for its own sake.

\section{Developing the Vision}

The Role of the Pastor

I will now seek to outline the initial steps to be taken in the proposed strategy of change in our churches. To accomplish a transition in the churches the role of the pastor is of paramount importance. Robert Schuller describes the role of the pastor poetically: "Almost without exception, the successful pastor is first of all an effective leader.... Real leadership is the quality that defines the role, sets the goal, the pays the toll. ${ }^{.2}$ The pastor must be the visionary, leading the way and describing the end goal for the church as he often is, in the early stages of the development, the only one in the church who

'Robert E. Logan and Thomas T. Clegg, Releasing Your Church's Potential (Carol Stream, IL: ChurchSmart Resources, 1998), 2-8. Handbook, 92.

${ }^{2}$ Robert Schuller, "Three Characteristics of a Successful Pastor," in The Pastor's Church Growth 
knows where it is headed and how it can reach that goal. This means unfortunately in practice that in many cases he is trying to achieve something he has received little seminary training for. The training and equipping of the pastor is then obviously a prerequisite which should be required and provided by the employing organization, and a system of coaching and mentoring of pastors needs to be set up.

The pastor must work with each church at its own pace in re-educating the people so as to make them understand the biblical concept of the ministry of the church. This can be accomplished through the weekly preaching and seminars held in the churches. One of the primary key issues that needs to be addressed at an early stage is the understanding of the members of the role of the pastor and the laity. Van Wyk points out that an important part of the work of the pastor at this stage is to build the self-concept of the congregation, to emphasize that the members "are real players on the Christian team and that the pastor is the coach. ... [Then] a new sense of identity begins to form. ... Many lay people in the church today have an inferiority complex. They fail to see that they are God's ministers and that great things can be accomplished through them."'

Second, an important task of the pastor is to follow Christ's model of close relationship with those who are being trained for ministry. It is important, especially in the beginning of the transition process, that the trainees, on the pastor's initiative, work together with the pastor in the different work situations they are to be engaged in.

In order to accomplish the desired transition in the churches the pastor must instigate an investigation of the present situation and the needs of each church. As we have mentioned one of the churches is much larger than the others. One is quite young

\footnotetext{
'Kenneth Van Wyk, "A Workable Model for Training the Laity," in The Pastor's Church Growth Handbook, 28.
} 
and enjoys the presence of many new members but it is to a large degree structured along traditional lines of pastoral leadership. The four remaining churches are small where in most cases no growth has taken place for a long time and their future existence will very much depend upon a revision of pattern from what is now the case.

\section{The Core Group}

A transition in the life of the churches from the present state of affairs to a new vision of the role of the church and a model of lay ministry according to spiritual gifts may take years to accomplish. Information about the proposed plan needs to be disseminated, first to hand-picked key individuals in the churches-the elders, the church board, and others trusted individuals-and then to the church at large.

It is suggested to start with a few members, chosen by the pastors from each of the churches, invited to spend a weekend at a retreat where the pastor not simply transmits the new vision but reinvents it through interaction and active engagement with the group. The purpose of this is to create a power base, a nucleus of key individuals in each church who can claim ownership of the vision and who will support the proposed transition. During the retreat the reading together of suitable literature and presentation of audiovisual material and discussions are important. On the lay ministry model Russell Burrill's book; Revolution in the Church, ${ }^{1}$ which exists in Icelandic translation, is ideal. The concept of Natural Church Development, ${ }^{2}$ which will form the basis for the evaluation and remodeling of the churches, must also be presented in a nutshell along

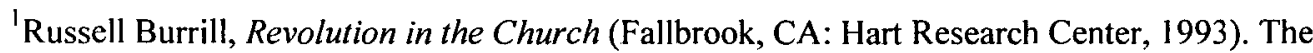
Icelandic title: Umbylting innan safnaðarins, published by Iceland Publishing House-Frækornið 1997.

${ }^{2}$ The book by Schwarz, Natural Church Development, also exists in Icelandic translation by the title Náttúruleg safnaðaruppbygging, published by the Iceland Publishing House-Frækornið, 2003. 
with other key concepts of church growth as a framework for transformation. But it is of key importance to keep the exercise deeply spiritual, to study the New Testament model and to pray much together.

As Burrill mentions, it is not easy to achieve a paradigm shift in churches set on the old model and there are always those among the members who are not going to move along. What is of utmost importance is to move slowly and be content with whatever partial progress there is achieved at each stage.

\section{Establishment of Small Groups}

In spite of resistance against change, one must not be overly pessimistic about the possibilities of results of the transition. An example of very successful remodeling is to be found in the early Methodist movement two hundred years ago, when John Wesley and his coworkers successfully engaged a great number of laymen thoroughly against the tradition of the time. His key to success, as also must be ours, was the small group. In his movement the small groups set the scene for lay participation, mutual support, and accountability where spiritual gifts were discovered and leadership training took place. ${ }^{2}$

The creation of small groups must originate on an individual basis and grow multilaterally rather than solely from a strong vertical incentive. The proliferation of groups must grow naturally from one to many as new leaders gain experience and are trained and initiate the multiplication. Here members of the core group should be the initiators and the small groups will then in turn be venues for spiritual revival, a growing sense of God's vision for the church's need for change, and for the discovery of personal

\footnotetext{
${ }^{1}$ Burrill, "Recovering an Adventist Approach to the Life and Mission," 293-96.

${ }^{2}$ See an account of the class meeting program in early Methodism in the third chapter.
} 
spiritual gifts. From the small group individuals are motivated to take part in the revitalization of the church within their own spiritual gifts, and training events must be organized to care for a growing need of leadership skills to accomplish the needed tasks.

\section{The Training Program}

As the concept of the laity taking over much of the operation of ministry in the church is a major element in the transition of the churches it is essential at this time to launce a ministry training program. It is suggested that two different venues of training be created for the four churches in question. The training that successfully can be carried out in one location for all of the churches could well be done at the former boarding school mentioned earlier. But then there is other training that must happen in the midst of the local church.

\section{General Courses}

The general courses that would be taught at the boarding school for members from all four churches are those that can successfully be taught without the interaction of the whole church body, or without an immediate practical training venue. Such are studies of Books of the Bible, Church History (Christian Church, Adventist Church, world wide and local), Doctrinal Studies, Principles of Church Growth and Natural Church Development, Christian Ethics, Finances, etc. The pastors, conference personnel, or other qualified individuals should teach these courses that would be offered at regular intervals.

\section{Local Courses}

The locally taught courses are those which require practical training, are of 
general interest for the whole church, and which build up the unity of the local church. Such are: Discovery of Spiritual Gifts, Christian Witnessing, Small Group Leadership, Giving of Bible Studies, Visitation Ministries, Youth Ministries, Sabbath School Teaching, Children's Ministries, Learning to Love, Communication Skills, Church Growth Principles, Family Ministries, etc. These courses would be taught in the churches according to need and interest. Here would also be offered introductions to the different offices in the church. Introduction of the Natural Church Development must also take place to the church body as a whole in order to acquaint the members with its concepts and thinking patterns.

In addition to the courses that aim at equipping the church members for their participation in the work of primary spiritual care for the church, other courses should be offered that are of a more general nature and could attract people from the community.

\section{Practical Application of the Eight Quality Characteristics}

Monitoring Growth Achievements

I will now attempt to outline the eight quality characteristics described by the NCD and apply them tentatively to our six churches. By focusing on and facilitating the performance of the churches within these quality characteristics, as observed through the lenses of the six biotic principles, the success of the churches in implementing the concepts introduced in the small groups, the training courses, and other church programs aiming at revitalization, can be observed and regulated. To habitually think in these terms increases accuracy and promotes the ability to determine the state of the church and makes the church profile easier to apply.

Due to individual differences in size and composition of the churches, different 
approaches will apply to them, and an individual church profile is important information in order to outline a strategy for each of them. I will suggest some points to bear in mind to accomplish growth in the eight quality areas based on the six biotic principles. Then attention will be drawn to some practical applications that could apply to the churches in question.

\section{Empowering Leadership}

\section{Description}

Empowering leaders recognize the vital significance of holistic interdependence within the church and encourage mutual recognition and teamwork and cooperation instead of competition (interdependence). They focus on the principle of reproduction seeing that the church will constantly need new leaders, and prioritize ongoing mentorship of new potential leaders (multiplication). They are able to discern and harness energy within all age groups (or other subdivisions) of the church with view to leadership, even among potentially strongly opposing individuals, thus not fighting obstacles but rather redirecting energy into a useful path (energy transformation). As they focus on constantly producing replacements for themselves by functioning as trainers of leaders while leading, they seek to maintain the impact of energy spent by making it reproduce itself (multi-usage). They recognize the possible benefit of the co-existence of different leadership styles (symbiosis) and that the crucial goal of all leadership is to promote qualitative and quantitative growth within the church itself and its leadership group (functionality). 


\section{Application}

Obviously the churches with their different needs will need their own set of leaders. But basic training of potential leaders emerging from within the churches (e.g., from the small groups) must be done together for all the churches where the vision is cast and skills developed for empowering leadership. Further leadership training could then also be shared by a larger church with a smaller, for example by the Hafnarfjörður, Suðurnes and Akureyri churches, on the one hand, and the Árnes, Vestmannaeyjar and Reykjavik churches on the other, and mentorship of leaders in different positions could also take place between churches to provide venue for experience not available in the smaller churches.

\section{Gift-Oriented Ministry}

\section{Description}

For the ministry in the churches to be gift oriented there must be an understanding of the role of spiritual gifts in the church, which are meant to work together like the parts of the physical body, each contributing to the unfolding and enriching of the whole, and the whole to stimulate each individual (interdependence). There is an understanding of the concept of the personal and corporate compelling need for the use of the gifts which thus multiply and are strengthened as in the parable of the talents (Matt 25:14-30) (multiplication), and by example others in turn are encouraged and helped to discover and use their gifts (energy transformation). A church emphasizing ministry of its members in their area of giftedness produces fulfilling and enjoyable service experiences which also encourages further participation (multi-usage). There is an understanding of the possibility for people with dissimilar gifts to work together to their mutual fulfillment and 
to the accomplishment of the mission of the church (symbiosis). The church actively helps its members to identify their particular gift(s) and employ them to the full (functionality).

\section{Application}

The process of discovering one's spiritual gift(s) is above all a personal and spiritual one based on much prayer, study of God's word and conscious experimentation, but it can be aided by the opinions and encouragements of brothers and sisters in the church. A continuous promotion of this process and the creating of opportunities to utilize the gifts must be an integral part of the program of each individual church as it is crucial especially for the new members to come to know and to have an opportunity to start to utilize their gifts early in their experience. This very appropriately happens within the small group setting and at special seminars as well as during private consultations.

\section{Passionate Spirituality}

\section{Description}

Conducive and indicative of high priority of spirituality in the church is that worship and prayer are a natural and integral part of the ministries of the church and not relegated to certain times and places only (interdependence). Passionate spirituality is not seen as essentially a private matter, but a reflection of the spirituality of the individual member is actively allowed to promote the corporate spirituality of the whole, as venues are created within the church where spiritual fervor is passed from one to another (multiplication). Strong, impassioned conviction and resolve within the church is steered 
into a deeply spiritual channel to become contributory toward a united fervor to praise and serve God (energy transformation). Emphasis on spirituality is a specific personal aim as well as a corporate aim of the church in order to promote its own spiritual health and to meet the needs of the unchurched neighbor (multi-usage). The church recognizes that genuine personal and corporate spirituality can be expressed in dissimilar ways but these are not mutually exclusive, do not need to compete with each other, and must be allowed to coexist (symbiosis). Joy and enthusiasm are the marks of a church whose members are in love with Christ (functionality).

\section{Application}

Passionate spirituality springs from an authentic love relationship with Jesus Christ as a personal savior and Lord. An acknowledgment of this fact is foundational to the existence of the church and is what gives it purpose and meaning. Each of our churches must thus constantly make it their first priority to promote spirituality in all its programs and arrangements. The small groups are an ideal venue for the ongoing spiritual experience and we can learn much from Wesley in his employment of the class meetings for this purpose. The essence and the purpose of the class meetings in Wesley's system was to be found in his insisting on "holy people or no people" and the primary task of mutual accountability. The task of the class members was to lovingly watch over each other by advising, exhorting, admonishing, and praying with the brother and sister. This and this alone in Wesley's mind is Christian fellowship.' The strong spiritual emphasis in the small groups will permeate the whole church and its programs.

\footnotetext{
'Watson, 116.
} 
Needless to say, the evangelism of the churches must be conducted with the following in mind: to introduce people to the Lord Jesus Christ and to urge them to receive him as a personal savior, and to receive the baptism of his Spirit, rather than simply persuade them to accept an appealing system of doctrines. Regrettably, too often in the past the church may have been guilty of being content merely with convincing people of right doctrine rather than leading them to a true conversion and a personal relationship with the person of Jesus Christ. As Ellen G. White puts it: "Many souls decide in favor of the truth from the weight of evidence, without being converted."

But our churches must also work together to enhance spirituality. One way is to arrange spiritual emphasis weekends together in the form of prayer conferences which engage the participants in Bible study and prayer together, followed by active witnessing and visitation in the community, concluding by spiritual celebration and sharing. Together the churches must also arrange retreats and camps of spiritual emphasis.

\section{Functional Structures}

\section{Description}

In order for the structures of the church to be functional each must be so designed as to further the program of the whole and the total mission. Some, which no longer serve the mission but are relics of the past or just maintain themselves, must be removed (interdependence). The structures must grow and multiply or change in accordance with the needs involved in the accomplishing of the main objective of the church: a living and vibrant witness for soul-winning within the society in which the church exists, and to

\footnotetext{
'White, Testimonies to the Church, 4:396.
} 
provide care and spiritual nurture within the church community itself (multiplication). Growth and opportunity in one area of ministry of the church must channel its energy and encourage growth in another area ${ }^{1}$ (energy transformation). Each structure in the church must also legitimize its own existence by generating the resources for its own operation and growth through its normal function (multi usage). . The different structures and programs of the church must coexist in a mutually beneficial relationship in a united effort towards the common goal of providing nurture for the body and to participate in the harvest of souls, thus building the kingdom of God cooperatively (symbiosis). The church must critically evaluate its structures and maintain and develop those which genuinely promote greater quality and multiplication of the church (functionality).

\section{Application}

Our six churches must independently critically evaluate their present structures with view to the above criteria and the local context in which they operate.

The evaluation of the structures of the churches calls obviously for clear understanding of the vision and mission of the churches. ${ }^{2}$ In some instances it may be a groundbreaking event actually to sit down and articulate and challenge the core values presently held by the church and validated through its corporate behavior, and thus seek to answer the question: "Who are we?" On the basis of the core values established, the churches must build their vision which is the "preferable future God wants to create through the church," answering the question: "Where are we going?" This vision must tie in, not only with the core values, but also the constitution and felt needs of the

\footnotetext{
${ }^{1}$ Logan and Clegg, 5-11.

${ }^{2}$ The following section is built on Logan and Clegg, 5-5 - 5-8.
} 
community at the present time. On the basis of this work the church must formulate its mission statement which is its charter and constant source of direction, which provides an answer to the question: "How will we get to the desired destination." Finally, the church must visualize the expected results of its ministry which are the specific outcomes, successes or failures, measured in answering the question: "Are we there yet?"

Only then is the church ready in an intelligible way to construct a set of structures as tools to accomplish the task at hand under the guidance of the biotic principles outlined above.

On the basis of this work a ministry flow chart must be worked out. McIntosh and Martin' suggest that the successful operation of the church can be described under the two headings of evangelism and assimilation, and they point out the need for every structure in the church to keep both aspects in mind in all its work. Logan and Clegg group the ministries of the church into the following categories: Pre-evangelism, evangelism, assimilation, growth and ministry, leadership, and church planting/missions. ${ }^{2}$ They suggest the following general ministry flow chart on the basis of categories Shown in figure 24 .

With view to our group of churches it is important that each church actively participate in the task of creating its own system of ministries built on the local needs and resources, which then are evaluated regularly on the basis of efficiency and sustainability. But it is significant for these churches to keep in mind the possibility of cooperation in

\footnotetext{
'Gary McIntosh and Glen Martin, Finding Them, Keeping Them (Nashville: Broadman and Holman, 1992).

${ }^{2}$ Logan and Clegg, 5-7, 5-18, 19.
} 
Target

Ministries

Attraction Worship \&

Events Celebration

\section{Newcomer}

Class
Relational

Evangelism

$\begin{array}{lll}\text { Small } & \text { Ministry } & \text { Leadership } \\ \text { Group } & \text { Involvement } & \text { Involvement }\end{array}$

Fish Pool

Events

Figure 24. General Ministry Flowchart. Robert E. Logan and Thomas T. Clegg, Releasing Your Church's Potential (Carol Stream, IL: ChurchSmart, 1998), 5-19.

supporting some of the ministries (e.g., those needing financial resources and highly skilled leadership). Special training events can easily be conducted for more than one church at the time as already suggested, and larger evangelistic and celebration events are enhanced by larger participation and the sharing of costs.

\section{Inspiring Worship Services}

\section{Description}

The worship service is the single most significant unifying factor in the life of the church and must seek to meet the needs of the different segments of the church (age, sex, intellectual preference, etc.), it must supply and anticipate the needs of other ministries, and make use of the wide variety of gifts in the church (interdependence). It must be evangelical in its orientation, making it an event where members of the small group can safely invite their unchurched contacts. Multiple services aimed at meeting the needs of different target audiences may need to be considered with a view to increase attendance (multiplication). Individuals who have newly been won to faith in Christ can renew the spiritual commitment of the congregation by an inspiring testimony (energy 
transformation). Allowance for a broad participation in the worship service by volunteers encourages and strengthens the participants and at the same time broadens the interest base for the contents of the service. It must be evangelistic in its emphasis and at the same time encourage and motivate for evangelism (multi-usage). The worship service must seek to mirror and reinforce the spiritual emphasis maintained in the small groups, and the spiritual momentum in the groups should seek to lead up to the spiritual celebration in the worship service ${ }^{1}$ (symbiosis). A regular, detailed evaluation of each part of the worship service must be carried out by the worship committee in order to ascertain whether it reaches its intended goal. Also, a regular check on attendance must be kept to see if it is increasing and whether visitors have been spotted and attended to appropriately (functionality).

\section{Application}

The worship service is a vital part in the program of our churches which need constant renewal and evaluation. The churches under review have mainly relied on ministers, often visiting from neighboring churches, for the preaching of the sermon. Consequently the services have often been lacking in indigenous flavor. The churches are blessed with quite a number of gifted and dedicated lay people who preach in the absence of a minister. But much more emphasis needs to be placed on the preparation of the services to make them varied, high quality, and inspirational for the tastes and needs of a widest possible audience. Here training is an unfulfilled need. All participants in the service need to receive instruction in order for the goal of the service to be achieved. And

\footnotetext{
Ibid., 6-15.
} 
here, yet again, training can easily be provided for more than one church at a time.

\section{Holistic Small Groups}

\section{Description}

The small groups in the churches, ministering to a variety of needs, must be interlinked in a system, and must be connected to other ministries in the church (interdependence). The group system must train group leaders in how to lead their group towards multiplication by appointing apprentice group leaders and seeking to increase membership and multiply (multiplication). The spiritual energy generated within the small groups must fire up the spiritual fervor with which the church as a whole approaches its mission, and groups, dealing with specialized problems, even potentially destructive ones, experiencing victory and growth, must be encouraged to share their experience with others in a similar situation (energy transformation). The small groups must have the dual function, through home-grown leadership, of promoting spiritual and emotional growth and well-being of its members, but also of recruiting and training leaders, of being a spiritual powerhouse, and of singling out spiritual gifts for the use in the church in general (multi-usage). Small groups with different operational purpose and program can coexist and mutually enrich each other and broaden the scope of the mission of the church and its versatility and receptivity for the harvest (symbiosis). The small groups must accommodate the needs of the whole church, they must increase the quality of its discipleship, and they must increase in number (functionality).

\section{Application}

Our churches, being very varied in size, will have very different relationships to 
the small group program. In most of them (Arnes, Sudurnes, Vestmannaeyjar and Akureyri) the whole church membership is not much more than two, or at the most three small groups, while in the larger churches a greater variety of groups can be established. The groups must grow and mature by themselves and within their own church context, but here, yet again, the training of leaders, their introduction to the biotic principles suggested above, the concept of coaching of group leaders, and the instilling in them a drive for comprehensive growth can be accomplished at a centrally organized event.

With regard to the operation of the groups we can again learn from the Wesleyan system where well-trained leaders carried out a key function in member care and spiritual nurture. Hunter states about Wesley that he "was driven to multiplying 'classes,' for these served best as recruiting groups, as ports of entry for new people, and for involving awakened people with the gospel and its power."1

Regular meetings of group leaders (Wesley insisted on weekly meetings) with the minister or, in the larger churches, supervisor(s) of small groups, for the sharing of results, experiences, and ideas and the carrying out of the coaching function must be maintained within the local church structure, but larger gatherings of leaders with supervisors and the pastors for wider input, sharing, and training, should also be maintained.

\section{Need-Oriented Evangelism}

\section{Description}

Evangelism must be the united effort of the whole church setting out to fulfill the Great Commission. This means that the different structures of the church must be geared

\footnotetext{
'Hunter, To Spread the Power, 56.
} 
and the leaders trained with a view to evangelism, that is the small groups, the worship leaders, etc., thus ensuring that the whole body, even people without the specific gift of evangelism, has an opportunity to participate in evangelism ${ }^{1}$ (interdependence). The 10 percent of the membership who are gifted evangelists must be identified and engaged in ministries where they can use their gift, ${ }^{2}$ and new Christians must be empowered to witness and relate to the needs of their unchurched friends, family, and co-workers (multiplication). Whatever program is planned by the church must be appraised by the gifted evangelists and the department leader for evangelism for its possible direct or indirect evangelistic effect (energy transformation). Evangelistic events are used as training events for the untrained gifted evangelists and others of the church thus supplying the church with well-trained personnel (multi-usage). Widely different approaches to evangelism must be able to coexist and inform each other in the church and there must exist respect for people and views during evangelistic activity (symbiosis). The church must actively engage in identifying the needs of the community and take steps to develop ministries that effectively and genuinely meet those needs in the context of sharing the gospel. The church must develop systems of evaluating its effectiveness in sharing the gospel in its cultural context (functionality).

\section{Application}

Evangelism is the method the church uses, as God's mouthpiece, to share the good news of the gospel with the world. Thus evangelism springs from the heart of the church in a special way because among all its activities this is the clearest expression of its reason

\footnotetext{
${ }^{1}$ Logan and Clegg, 8-13.

${ }^{2}$ Schwarz and Schalk, 114.
} 
for existence: a mission to a lost world. In the light of this it clearly is not the fulfillment of the purpose of the church to be an institution which solely provides a fulfilling, nurturing environment for its faithful members. In order for the church to be more than a religious club and to really live up to its name as the church of Jesus Christ, its focused attention must be on the lost world, specifically on the lost members of the community in which it is located, thus reflecting the sentiment of its founder and Lord, who portrayed himself as the shepherd who leaves the ninety-nine in order to seek for the one lost sheep. If the church exists to save the lost world then evangelism must be need-oriented, geared towards fulfilling the needs of the unsaved.

Even though our churches need only engage in evangelism in a homogenous society (E-1, E-2 evangelism) their task is daunting in the highly materialistic and secular society characteristic of Western Europe. Furthermore, our churches have little experience in active participation in evangelism. What evangelism has been carried out in their churches has mainly been done by professionals, requiring little practical help from the church members themselves. To equip the churches for strategic evangelism, using as the point of contact the felt needs of the individuals in the community, will take a holistic reorientation of the churches, beginning with clearly outlining the values and vision of the church.

\section{Loving Relationships}

\section{Description}

Loving care must become the prevailing, perceptible attitude of the church, exhibited among church members, towards visitors, and towards the unbelieving community in which the church is located as an expression of concern and a deep-seated 
sense of responsibility for the well-being of others (interdependence). Authentic expressions of love and care should become a conscious campaign within the faith community as well as a part of the outreach of the church under the principle, that one exemplary loving relationship will stimulate another, creating a chain reaction (multiplication). Attention should be focused on opportunities where the love and care of Christ experienced in the heart of the believer is allowed to transform the relationship with others (energy transformation). The maintaining of a genuinely loving attitude in the church is an energy-absorbing effort on the part of the members, but it is energy well spent as it attracts new believers, it smooths the operation of the church, and breeds joy, peace and satisfaction in the lives of the members (multi-usage). In the relationships of dissimilar structures within the church love, respect, and concern for the views of others must be emphasized (symbiosis). Attention should be given to whether in fact the members, the visitors, and the surrounding community perceive that love in action is present in the church (functionality).

\section{Application}

While love is confessed to be the heart of the Christian message the practical application of loving relationships has received precious little focused attention in the churches. This is pretty much left to develop on its own as a result of personal encounter with the Lord and as a by-product of the doctrinal teaching and preaching. Undeniably, the true source of love is a relationship with the Lord, who is the origin of love, but human nature needs the encouragement and the support of the group to attain spiritual growth, also within the area of expressing love. Surely the church of Christ must be the chief venue in the world for the training of a loving attitude, attitude of concern and compassion 
as it seeks to exhibit God's love for mankind.

But we must recognize that emotional barriers often hinder a person's expression of love and affirmation. This is related to the concepts of self-worth and self-image and in turn to communication skills and the ability of a person to build authentic relationships. The churches must seek to promote emotional as well as spiritual health in its members, and promote love and relational skills within families, which thus are enabled to produce balanced and emotionally healthy young ones. The fragrance of love, more than anything else, makes the church an attraction and paves the way for people to seek to enter it and to find a saving, regenerating relationship with the Lord Jesus Christ. In the words of Ellen G. White: "The strongest argument in favor of the gospel is a loving and lovable Christian."1

Our six churches must include this aspect in their church program by first of all consciously including it in their vision and mission statements, and also deliberately make expressions of love and concern a part of the agenda of the small group ministry visibly portrayed in the worship services. ${ }^{2}$ Second, a Learning to Love course should be taught regularly in the local churches, or with the common courses run for all the churches, along with courses in communication skills, conflict management, marriage enrichment, and family life. Counselors should also be trained who can teach such courses and provide primary help for individuals or couples. Third, a strategy should be developed to extend love and compassion to the community in which the church is located through community service and an effort to identify with the problems and concerns of the community.

\footnotetext{
${ }^{1}$ White, The Ministry of Healing, 470.

${ }^{2}$ Logan and Clegg, 9-10.
} 
Fourth, love should also be translated into action within the church itself as leaders and supporters, not overburdened with responsibilities in carrying out the program of the church, conscientiously emphasize praise, appreciation, and encouragement as a regular feature within it.'

\section{Continuation of the Process and Evaluation}

I have here attempted to draw up a sketch of the eight quality characteristics in relationship to the six biotic principles and suggested a preliminary initial application of these to the six churches. This must be introduced to the leaders and the members of the churches as they are gradually being familiarized with the working concepts of NCD through the training courses and other events. In this way an effort is made to introduce to those in leadership positions and regular members what NCD people call "biotic thinking": "Natural church development aims at releasing those growth dynamics which God himself uses to build his church. But if this statement is to be more than just theological rhetoric, we have to ask: How does this happen practically? ... [A] training program will help responsible leaders increasingly integrate the categories of biotic principles into their thinking and into their decisions-thus becoming more sensitive to God's growth "automatisms."”'

But in order to efficiently implement the NCD concept a church profile must be conducted in all the churches. This will reveal the minimum factor, and a process of raising the minimum factor by mobilizing the strength of the church (the maximum factor) must be embarked on according to the ten action steps described earlier.

\footnotetext{
'Schwarz and Schalk, 121.

${ }^{2}$ Ibid., 123 .
} 


\section{Summary}

The six Adventist churches in Iceland are in need of a strategy of growth and revitalization. It is the concept of this project that such a revitalization must be built on the foundation of spiritual revival and a new vision of participation in the harvest of souls for the Kingdom of God.

The organizational changes suggested include the involvement of trained laity in the operation of the church program with view to primary member care and evangelistic outreach, based on spiritual gifts, the organization of small groups, and the reorganization of ministry structures of the churches.

It is suggested that in many ways the churches can assist each other even though they are geographically separated from each other and are different with regard to size and contextual situation. First, it is suggested that the larger churches (Reykjavik and Hafnarfjordur) can assist the smaller ones, or even the whole group of churches could go together in caring for some specialized ministries which the smaller churches find difficult to operate on their own, such as youth ministry, family ministry, charity work, etc.

Second, training events for leaders and members can be organized jointly between the churches at Hliðardalsskóli (the former boarding school) where regularly scheduled courses can be offered. Third, the churches must organize between themselves spiritual emphasis weekends, prayer conferences, and retreats and camps, where especially the smaller churches will benefit from the interaction with a larger body.

The guiding church growth concept outlined and applied to the churches in this paper is that of the Natural Church Development. This program emphasizes the discovery of the divine laws, the biotic principles, governing the growth mechanisms of the church 
to release the growth potential present in the churches, and it recommends regular comprehensive evaluation of the quality of discipleship in the churches in the eight different areas, claiming that spiritual and organizational quality church growth will lead to numerical church growth. 


\section{CHAPTER VI}

\section{SUMMARY, CONCLUSIONS, AND RECOMMENDATIONS}

\section{Summary and Conclusion}

The task of this dissertation has been to propose a strategy of revitalization for the churches of the Iceland Conference by increasing their quality of church life, raising theirs self-identity and sense of mission, and strengthening their ability to reach the community and to grow.

I have found that this undertaking must take as its point of departure the Great Commission of Christ to his disciples in Matt 28 and the messages of the three angels in Rev 14.

By comparing these mission statements we found that whereas the method of mission in Matthew's Gospel is that of making disciples by baptizing them and teaching them all that Jesus commanded, the Revelation passage intensifies all these aspects of the Great Commission and places it in the context of the judgment as having already begun and the release of God's people as already underway. Here the three angels symbolize Christ's followers clothed in his righteousness and empowered by the protection and closest possible communion with their Lord as they are effectively engaged in the proclamation of the eternal gospel. In fact the Revelation text portrays the messengers having assimilated their message in their own life as symbolized in the text of their song 
issuing forth from the context of worship, lived but never learned without authentic experience. It is an existential proclamation.

We then examined the prophetic counsel of Ellen G. White to the Adventist church as it engages in this task and found that she urges less clergy dependancy in the church, more recognition of spiritual giftedness of both clergy and laity, more evangelism-orientation in the church as the pastor and the members work together in this most supreme task, more attention given to the training of the laity for service in the church, and, finally, greater and more open spirituality in the church as all are encouraged to share their personal experience with the Lord for mutual encouragement.

In the third chapter I attempted to summarize the main contributions of the key advocates of the Church Growth Movement, a program that has at its core the aim to approach the development of the church and evangelism scientifically. Empirical research and analysis of growth by removing the guesswork from methods and means to grow the kingdom on earth have become its most absorbing undertaking.

We found that the strongest contribution of the movement at a time of liberal theology and erosion of biblical authority was its fundamental spiritual conviction that God desires that all of humanity be saved and that the church's primary purpose is to be a faithful and effective witness to the saving reality to be found in the death, resurrection, ascension and return of the Lord Jesus Christ.

In the future mission of the church there are contributions of the church growth movement, a legacy that must never be lost sight of, which will guide the church to success, such as its emphasis on precision of work and constant measurement of results which keeps the church on course toward a well-defined goal. What needs to be kept in 
mind as this approach is upheld is a maintenance of balance of monitoring results without an exaggerated obsession with numbers.

I have listed the main church growth principles and studied reports of their practical application, also within an European setting, and found them to be valid and applicable.

After an interlude where we studied the role of a cell movement, the class meeting, in early Methodism, I analyzed the cultural shift taking place especially in Western society as modernity gives way to postmodernism and how methods of church development and evangelism that were effective in the last decades of the last century need to be reframed in order to account for this fundamental change in thinking. We also noticed that even though the impact of the postmodern thought in conjunction with the effects of the Information Age, pluralistic society and increased globalization has raised some serious doubts about the future of institutionalized religion, this shift has opened up unique possibilities as the spell of modernity has been broken and that deconstruction may present itself as a potent ally for Christians who wish to reintroduce mystery and the supernatural into human experience.

We then studied the entry of the Adventist church in Iceland at the turn of the twentieth century and the development of the church during the last 100 years. A combination of providential timing, hard work, good planning and methodology, receptivity in the nation, the cultural sensitivity of the pioneers coupled with the rich blessings of God, caused the work to flourish in the beginning. As contextual factors changed, the work fell on hard times. The church tried to retain members by such means as the operation of schools and strengthening of the youth work while traditional methods 
were relied on to provide for conversion growth: the literature work, public evangelism, and Bible courses by correspondence. But as we have seen the Adventists in Iceland failed to create in their local churches self-supporting communities that were able to reproduce themselves. Their reliance on institutionalized efforts of evangelism and a lack of personalized projects made the smaller churches heavily dependent on outside support, and they were liable to suffer and some even ceased to exist when not attended to by the conference or as members moved to the larger churches or were needed to support some of the church institutions.

The core concept for the redirection of the churches in Iceland I propose to be that of Natural Church Development which seeks to aid churches to release divine laws governing the growth mechanisms of the church and thus release its growth potential. But the restructuring of a church program is a slow and demanding process. The greatest obstacle to be encountered is the change of paradigm from the present model of settled pastors, minimal involvement in evangelism, and the concept of the impossibility of success in mission outreach, to that of the new vision of active involvement of the whole church body, on the basis of spiritual gifts in the operation of the church, and in the fulfillment of the real purpose of the church, which is to be an authentic witness to a lost world.

This monumental task will be achieved only if, first, it is built on the foundation of a personal encounter with God by the members as individuals and as a corporate body, or by the church developing a passion for God. Second, it is necessary that the members individually and as a corporate body acquire God's attitude to the lost world, namely, a passion for seeking the lost. 
To catch the vision of the Adventist mission means, first, to be thrilled and captivated by the conviction that Jesus, the lover of humanity, is coming soon. Second, it means to be a willing coworker of Jesus in the task of forming a people who are truly disciples of his, who keep the commandments of God, who remain faithful to Jesus, and who will follow him wherever he goes.

\section{Recommendations}

Introduction

As we have seen in the above analysis of the general condition of Adventist churches in Iceland, there is a very present need for revitalization and renewal. The churches are all, but one, older churches ranging in age from 50 to 100 years old. One of the churches is much larger than the others but the membership and attendance is small and declining. One is quite young and enjoys the presence of many new members but it is to a large degree structured along traditional lines of pastoral leadership. The four remaining churches are very small where in most cases no growth has taken place for a long time or are actually declining, and their future existence will very much depend on a change of pattern from what is now the case.

I have already in the previous chapter suggested a course for the churches to follow in order to achieve renewal, that of the creation of a renewed biblical vision of the purpose and mission of the church and the launching of a diagnostic and a healthimproving program to promote renewed internal and external growth.

No one with experience in these things will claim that this process is an easy one, but the rewards are, when the program succeeds, the more desirable and worth striving for. 
I will now suggest some steps that should be included in the implementation of the proposed revitalization process of the Adventist churches and the conference in Iceland.

Key Issues in the Implementation Process of Renewal

\section{A Vision of a Searching God}

A motivation to engage in the strenuous work of church renewal cannot be successfully generated through a mere wish for the church to grow in numbers or to maintain its existing service for ourselves or our children, let alone to maintain a heritage for the sake of tradition. The purpose of the church is to bring honor and glory to God who loved the world so much that he gave the most precious gift conceivable, his only Son. The great passion of God is that the lost be found and that his most precious provision for their eternal well-being be made available to all humanity. Thus the saving of the lost brings joy to God: "I say to you, that likewise joy shall be in heaven over one sinner that repenteth, more than over ninety and nine just persons, which need no repentance. ... Likewise, I say unto you, there is joy in the presence of the angels of God over one sinner that repenteth" (Luke 15:7, 10).

Here is a picture of God that we must constantly behold. He is a God who loves and searches for sinners. People matter to God and he yearns for the salvation of the lost. So also must we who have tasted his salvation and are recipients of his provisions.

\section{Spiritual Renewal}

A realization of the critical need for a church renewal and a change of course must drive us to our knees in search for a spiritual renewal. Such renewal must begin among 
the leadership team of the church. The pastoral team of the conference as well as local church leadership must set time aside, personally and corporately, for prayer and study of the Word and the wealth of material on spiritual revival from the pen of Ellen G. White. Spiritual retreats must be planned where leaders pray, study, lay plans together, and confess their sins of both commission and omission before the Lord and each other. Genuine revivals cannot be manufactured, but by faithfulness in confession and prayer the Lord is faithful and willing to forgive and pour out his Holy Spirit (Luke 11:13).

Then the whole church must be involved in the renewal. Such a moment is an ideal opportunity to for a change as the people become receptive: "At this time the Holy Spirit manifests Himself in special power to the church and the presence of the Spirit always leads the church back to its mission."'

\section{A Sense of Purpose and Mission}

The churches must have a clear statement of purpose and mission set before them as they easily become bogged down in routine maintenance and programs. Thus to study the function of the church in the light of the mission Christ presented it with initially is essential. As we have seen, there is no more definitive command given in Scripture by Jesus himself than the one to engage in the salvation of mankind: "All authority has been given to Me in heaven and on earth. Go therefore and make disciples of all the nations, baptizing them in the name of the Father and the Son and the Holy Spirit, teaching them to observe all that I commanded you; and lo, I am with you always, even to the end of the age" (Matt 28:18-20).

\footnotetext{
${ }^{1}$ Russell Burrill, Waking the Dead (Hagerstown, MD: Review and Herald, 2004), 45.
} 
James E. White summarizes what is, according to this passage and from Acts $2: 42-47$, the core mission of the church: "The mission of the church is to reach out to nonbelievers and develop them, along with existing believers, into committed followers of Christ. This is the mission the purposes of the church are intending to accomplish.... As people participate in the evangelism, discipleship, ministry, worship, and community of a church, activities that function under the overall mission of the church, they develop into fully devoted followers of Christ who are ready to serve him."

It is essential to recapture the biblical sense of purpose of the church and to examine all that the church is doing in that light, as: "such a move would create a climate for extremely effective rethinking, because when church members look at their church through the lens of its purposes, it enables them to know what to say yes to as well as what to say no to." Further, it is of paramount importance that each church be encouraged to work on its own statement of mission reflecting the Great Commission and calling for the use of all the resources of the church in the building up of the kingdom of God.

\section{Reclaiming of First Love}

Most of the churches in Iceland have come of age and the enthusiasm of the beginning of the church and the early years has in most cases been long forgotten. Burrell $^{3}$ points out that an important factor in moving forward is to take time to research the history of the church in order to discover what it was that brought success in the past

\footnotetext{
'James E. White, Rethinking the Church, 33

${ }^{2}$ Ibid., 31 .

${ }^{3}$ Burrell, Waking the Dead, 56.
} 
and also to be reminded of remarkable achievements and evidence of divine leadership and intervention.

\section{Strategy of Evangelism}

The challenge of postmodernism

As is the case in many Western countries, public evangelism has long since ceased to yield the results in Iceland that it used to. Perhaps earlier presentations were too limited to an objective delivery of factual information. We may now have entered a new era of postmodernity that requires a different approach, the implications of which may be long overdue in our circles. There is a call for Christianity that is more than a mere adherence to confessional statements of truth and the enhancement of an institution.

There is a call for an honest witness about a spiritual, personal, practical religion that makes a difference in the person's life. In presenting Christianity to the postmodern the witness must be prepared to be questioned at every point, not only in the area of basic beliefs but also in relation to obedience based on those beliefs. Does our orthodoxy translate into orthopraxis? Do we practice what we preach? Are we seeking to live by an unconditional and radical commitment to our beliefs, whatever the personal cost? ... Only in so far as Christians are prepared for their own position to be scrutinized at close quarters will they be in a position to persuade postmodernists to critique their own assumptions.'

Then again, that sounds like a description of the intimate relationship enjoyed by Christ's end-time followers found in Rev 14:1-5!

Cultural sensitivity

We must learn from the pioneers in Iceland who ministered to the needs of the community, identified with the culture, and showed disinterested love to the target

'Gibbs, Church Next, 28, 29. 
population as this also today opens people's hearts for the sharing of the gospel. This was the experience of both Östlund and Olsen and also the work at Hliðardalsskóli as I have related above. In this respect we can also learn much from the approach of early Methodism described by Hunter.

Wesley traveled to communities with an entourage, which ministered as a team to a community, usually with the goal to plant a Methodist society or to start new classes within a society. Methodism engaged people's imaginations through Charles Westley's poetry and the folk arts of the people. Early Methodism employed an alternative architecture in which people felt comfortable, which was conducive to fellowship and to sensing the imminence of the Triune God. Early Methodism adopted the people's kind of music, and many people sang their way into faith. ${ }^{1}$

Seek new segments in society

In our evangelism we must seek to reach the different segments of the increasingly pluralistic society and those who have no working knowledge of Christianity. This we have far from accomplished through our traditional approach which tended to anticipate at least a basic knowledge if not acceptance of Christianity in the target audience. This requires an introduction to the basics of Christianity before more advanced themes of traditional Adventist topics are presented. Groups within society may be targeted such as new immigrants or people with special needs, such as people with addiction.

New methods of presentation

We must also pay attention to the insight that people find faith today by acculturation, or by being brought into "Christian community, and into the ministry of conversation."2 Hunter refers to a study by Berger and Luckman, The Social Construction

\footnotetext{
'Hunter, 99.

${ }^{2}$ Hunter, 99.
} 
of Reality ${ }^{1}$, which explains through what process people, especially within a pluralistic society, will change the way they perceive reality, for examle, convert to a new religion: “(1) A person's view of Reality is largely shaped, and maintained, within the community into which one has been socialized. (2) In a pluralistic society, the possibility of conversion, that is, changing the way one perceives essential Reality, is opened up through conversation with people who live with a contrasting view of Reality, and (3) one adopts and internalizes the new worldview through resocialization into a community sharing that new worldview."

One approach in evangelism that is taking these insights seriously, which also is well known in Iceland, is the Alpha course from Holy Trinity Church in Brompton, England. Many different denominations other than the Adventists have conducted Alpha courses, usually with good success.

\section{Role of the Conference in Evangelism}

In Iceland the Conference has had, throughout most of the history of the church, a very prominent role in the Adventist evangelistic activity in the country. So much so that the function and the responsibility of the local church and the members themselves have been overshadowed. It is recommended that the Conference occupy more of a supportive role of providing expertise and financial and material resources for evangelism in order to support the local churches in their evangelistic activity.

\footnotetext{
'Peter Berger and Thomas Luckman, The Social Construction of Reality: A Treatise in the Sociology of Knowledge (New York: Doubleday, 1966).

${ }^{2}$ Hunter.
} 


\section{Role of the Local Church}

The church development program suggested in this paper emphasizes the strengthening of the role and function of the local church. It seems clear from the study of the history of the churches that some, if not all, have lacked empowered local leadership and resources to maintain an effective evangelistic program which could provide natural growth of the church. This proved detrimental to all of them and even fatal to some. It is thus recommended that evangelistic activity within the area of an existing local church be planned and run with the resources of that church or at least with its active participation in conjunction with whatever support is needed and available from the conference, and that training of local leadership be made a priority.

\section{Small Group Ministry and Lay Participation}

As has been noticed, the function of the small group is of paramount importance in spiritual nurture, creation of community, spiritual formation and accountability, recruiting of new lay-leaders, and the evangelistic effectiveness of the church. It appears as one of the quality characteristics in the Natural Church Development program so it may not seem necessary to mention it specially. Still its role seems so important in breaking out of the course of present stagnation and decline that special effort should be made to promote a small group program wherever possible. 


\section{SELECTED BIBLIOGRAPHY}

Agnew, Theodore L. "Methodism on the Frontier." In The History of American

Methodism, ed. E. S. Bucke, 1:488-546. Nashville, TN: Abingdon Press, 1964.

Allen, Diogenes. "The End of the Modern World." Christian Scholar's Review 22, no. 4 (993): 345-351.

Allen, Roland. Missionary Methods: St. Paul's and Ours: A Study of the Church in the Four Provinces. London: Robert Scolt, 1912.

. Pentecost and the World: The Revelation of the Holy Spirit in the 'Acts of the Apostles. 'London: Oxford University Press, 1917.

. The Spontaneous Expansion of the Church and the Causes Which Hinder it. London: World Dominion Press, 1927.

Allison, Lon, and Mark Anderson. Going Public with the Gospel: Reviving Evangelistic Proclamation. Downers Grove, IL: InterVarsity Press, 2003.

Anderson, N. "Fra Island." Missionsefterretninger, January, 1913, 3.

. "Fra Island." Missionsefterretninger, July, 1913, 50.

Anderson, Walter Truett. Reality Isn't What It Used to Be: Theatrical Politics, Ready-toWear Religion, Global Myths, Primitive Chic, and Other Wonders of the Postmodern World. San Francisco: Harper \& Row, 1990.

Arias, Mortimer, and Alan Johnson. The Great Commission: Biblical Models for Evangelism. Nashville: Abingdon Press, 1991.

Arn, Win. The Church Growth Ratio Book: How to Have a Revitalized, Healthy, Growing, Loving Church. Pasadena, CA: Church Growth, 1987. , ed. The Pastor's Church Growth Handbook. Vol 2. Pasadena, CA: Church Growth Press, 1982.

Arnold, Jeffery. Big Book on Small Groups. Downers Grove, IL: InterVarsity Press, 1992. 
. Seven Tools for Building Effective Groups. Colorado Springs, CO: NavPress Publishing Group, 1997.

Arvey, William O. Revitalizing Congregations. Bethesda, MD: The Alban Institute, 2002.

Åsbø, Erik. Evangelii Harold, 6 October 1921.

Barber, Diane, and Kent R. Hunts. Facing the Facts for Church Growth. Corunna, ID: Church Growth Center, 1985.

Barclay, William. The Letter to the Ephesians. The Daily Study Bible. Vol. 10.

Edinburgh: Saint Andrews Press, 1974.

. New Testament Words. London: SCM Press, 1964.

. Revelation of John. The Daily Study Bible. Vol. 17. Edinburgh: Saint Andrews Press, 1974.

Barna, George. A Fish Out of Water. Nashville, TN: Integrity Publishers, 2002.

. The Frog in the Kettle. Ventura, CA: Regal Books, 1900.

. Grow Your Church Outside In. Ventura, CA: Regal Books, 2002.

. The Habits of Highly Effective Churches. Ventura, CA: Regal Books, 1999.

. Marketing the Church. Colorado Springs, CO: NavPress, 1988.

. Never on a Sunday: The Challenge of the Unchurched. Glendale, CA: The

Barna Research Group, 1990.

. The Power of Vision. Ventura, CA: Regal Books, 1992.

. The Second Coming of the Church. Nashville, TN: Word Publishing, 1998.

. Turn-Around Churches. Ventura, CA: Regal Books, 1993.

. User Friendly Churches. Ventura, CA: Regal Books, 1991.

Barth, Karl. Church Dogmatics. Translated by G. T. Thomson. Edinburgh: T \& T Clark, 1958.

Baumgartner, Erich W. "Towards a Model of Pastoral Leadership for Church Growth in German-Speaking Europe." Ph.D. dissertation, Fuller Theological Seminary, 1990. 
Beasley-Murray, Paul, and Alan Wilkinson. Turning the Tide. London: Bible Society, 1981.

Beckham, William A. The Second Reformation: Reshaping the Church for the $21^{s t}$ Century. Houston, TX: Touch Publications, 1995.

Berger, Peter, and Thomas Luckman. The Social Construct of Reality: Treatise on the Sociology of Knowledge. New York, NY: Doubleday, 1966.

Björgvinsson, Guðjón. "Vér undirskirfađir," Saga Fríkirkjunnar i Reykjavik. Reykjavík, 1999. Unpublished paper.

Borholm, Richard R. "The Evangelizing Community and Social Transformation." Foundations 20 (January-March 1977): 352-361.

Bosch, David. Transforming Mission: Paradigm Shifts in the Theology of Mission. Maryknoll, NY: Orbis Books, 1991.

."The Structure of Mission: An Exposition of Matthew 28:16-20." In Exploring Church Growth, ed. Wilbert R. Shenk. Grand Rapids, MI: Eerdmans, 1987.

Brattlett, W. T. "Iceland." Review and Herald, 23 November 1933, 24.

Bræðrabandið, December 1966.

Bruce, Charles Robert. "Testing a Modified Model of Class Meeting in a Modern Setting as a Means of Increasing Lay Activity and Participation." Ph.D. dissertation, Drew University, 1985.

Bruce, Jerome E. Proclaiming the Scandal: Reflections on Postmodern Ministry. Harrisburg, PA: Trinity Press International, 2000.

Bruner, Frederic Dale. Matthew. Vol. 2, The Churchbook. Dallas, TX: Word Publishing, 1990.

Burrill, Russell. Creating a Healthy Adventist Church through Natural Church Development. Berrien Springs, MI: North American Division Evangelism Institute, 2003. . Radical Discipleship for Revolutionary Churches. Fallbrook, CA: Hart Research Center, 1996.

. Recovering an Adventist Approach to the Life and Mission of the Local Church. Fallbrook, CA: Hart Research Center, 1998. 
. "Recovering an Adventist Approach to the Life and Mission of the Local Church." D.Min. dissertation, Fuller Theological Seminary, 1997.

. Rekindling a Lost Passion. Fallbrook, CA: Hart Research Center, 1999.

. Revolution in the Church. Fallbrook, CA: Hart Research Center, 1993.

. The Revolutionized Church of the $21^{\mathrm{st}}$ Century. Fallbrook, CA: Hart Research Center, 1997.

.Waking the Dead: Returning Plateaued and Declining Churches to Vibrancy. Fallbrook, CA: Hart Books, 2004.

Cheany, L. Charles, and Ron S. Lewis. Design for Church Growth. Nashville, TN: Broadman Press, 1977.

Cho, Paul Yong-gi. Prayer, Key to Revival. Dallas, TX: Word Publishing, 1984.

. Successful Home Groups. North Brunswick, NJ: Bridge Publishers, 1981, 1999. Reprint.

Conn, Harvie M. "Looking for a Method: Backgrounds and Suggestions." In Exploring Church Growth, ed. Wilbert R. Shenk, 85. Grand Rapids, MI: Eerdmans, 1983.

Conn, Harvie M., ed. Theological Perspectives in Church Growth. Den Dulk Foundation, 1976.

Costas, Orlando. The Church and Its Mission: A Shattering Critique from the Third World. Wheaton, IL: Tyndale, 1974.

. Liberating News: A Theology of Contextual Evangelization. Grand Rapids, MI: Eerdmans, 1989.

. "A Wholistic Concept of Church Growth." In Exploring Church Growth, ed. Wilbert R. Shenk, 95-107. Grand Rapids, MI: Eerdmans, 1983.

Cox, David. Future Church. Grantham, UK: Stanborough Press, 2001.

Think Big, Think Small Groups. Grantham, UK: Department of Personal Ministries, 1998.

Crawford, Dan R. Church Growth Words from the Risen Lord. Nashville, TN: Broadman Press, 1990.

Cyclopedia of Methodism. 1878 ed. S.v. "Clark, Adam, LL. D." 
Davies, Horton. Worship and Theology in England. Vol. 3, From Watts and Wesley to Mertineau, 2d ed. Grand Rapids, MI: Eerdmans. 1996.

Davies, Rupert, ed. The Works of John Wesley. Vol. 9. Nashville: Abingdon Press, 1989.

Dean, William Walter. "Disciplined Fellowship: The Rise and Decline of the Cell Groups in British Methodism." Ph.D. dissertation, University of Iowa, 1985.

."The Methodist Class Meeting: The Significance of Its Decline." Proceedings of the Wesleyan Historical Society 43 (December 1981): 41-48.

Douglas, J. D. Let the Earth Hear His Voice: International Congress on World Evangelization Lausanne, Switzerland. Minneapolis, MN: World Wide Publications, 1975.

Doukhan, Jacques B. Daniel: The Vision of the End. Berrien Springs, MI: Andrews University Press, 1987.

Dugas, Jacqueline. Transforming Our Nation: Empowering the Canadian Church for a Greater Harvest. Richmond, British Columbia: Church Leadership Library, 1998.

Dunagin, Richard L. Beyond These Walls: Building the Church in a Built-out Neighborhood. Nashville, TN: Abingdon Press, 1999.

Dybdahl, Jon. "Into the World of the $21^{\text {st }}$ Century." Spectum 26 (May 1997): 31-35.

Ellas, John W. Measuring Church Growth: A Research-Based Tool for Evaluation and Planning. Houston, TX: Center for Church Growth, 1997.

"Ellen G. White Comments-1 Corinthians." Seventh-day Adventist Bible Commentary. Edited by F. D. Nichol. Washington, DC: Review and Herald. 195357. 6:1082-93.

"Ellen G. White Comments-Ezekiel." Seventh-day Adventist Bible Commentary. Edited by F. D. Nichol. Washington, DC: Review and Herald. 1953-57. 4:1160-66.

"Ellen G. White Comments-Isaiah." Seventh-day Adventist Bible Commentary. Edited by F. D. Nichol. Washington, DC: Review and Herald. 1953-57. 4:1137-54.

"Ellen G. White Comments-Revelation." Seventh-day Adventist Bible Commentary. Edited by F. D. Nichol. Washington, DC: Review and Herald, 1953-57. 7:953-90.

Erickson, Millard J. The Word Became Flesh. Grand Rapids, MI: Baker Books, 1991.

Exman, Gary W. Beyond the Numbers Game. Lima, OH: Fairway Press, 1997. 
Fell, Michael. And Some Fell into Good Soil: A History of Christianity in Iceland. New York: Peter Lang Publishing. 1999.

Ferguson, Charles W. Organizing to Beat the Devil: The Methodists and the Making of America. Garden City, NY: Doubleday, 1971.

Ferm, Robert O. The Power of Cooperative Evangelism. Wheaton, IL: Evangelism and Mission Information Service (EMIS), 2002. Originally Published in 1958 by Zondervan, Grand Rapids, MI, as Cooperative Evangelism.

Folkenberg, Robert, Jr. "The Creation of a Natural Church Development Coaching and Implementation Guide for the Seventh-day Adventist Church." D.Min. dissertation, Andrews University, 2001. . Health for the Harvest: Four Inspiring Steps to Total Congregational Health. Berrien Springs, MI: North American Division Evangelism Institute, 2002.

Ford, Kevin Graham. Jesus for a New Generation. Downers Grove, IL: InterVarsity Press, 1995.

Fortune, Don, and Katie Fortune. Discover Your God-Given Gifts. Grand Rapids, MI: Chosen 21 Books, 1987.

Fudge, E. W. The Fire That Consumes. Fallbrook, CA: Verdict Publications, 1982.

Gaustad, Edwin Scott. Historical Atlas of Religion in America. New York: Harper and Row, 1962.

Gelder, Craig van, ed. Confident Witness-Changing World: Discovering the Gospel in North America. Grand Rapids, MI: Eerdmans, 1999.

George, Carl F., and Robert Logan. Leading and Managing Your Church. Old Tappan, NJ: Fleming H. Revell, 1987.

Gerber, Virgil. God's Ways to Keep a Church Going and Growing. Glendale, CA: Regal Books, 1973.

Gibbs, Eddie. Church Next: Quantum Changes in How We Do Ministry. Downers Grove, IL: InterVarsity Press, 2000. . I Believe in Church Growth, rev. ed. London: Hodder and Stoughton, 1985.

Gíslason, Óskar. Interview by author, University of Iceland, 1982. 
Gladden, Ron. The Seven Habits of Highly Ineffective Churches: Why Your Church Has Stopped Growing and What to Do About It. Vancouver, WA: Adventist Church Planting Center, 2003.

Glock, Charles Y., and Rodney Stark. Religion and Social Tension. Chicago, IL: Rand McNally, 1965.

Goen, C. C. Broken Churches, Broken Nation: Denominational Schisms and the Coming of the American Civil War. Macon, GA: Mercer University Press, 1985.

Goss, C. C. Statistical History of the First Century of American Methodism. New York: n.p., 1866.

Grenz, Stanley. "The Community of God: A Vision of the Church in the Postmodern Age." Crux 28 (June 1992): 19-25. . A Primer on Postmodernism. Grand Rapids,MI: Eerdmans, 1996.

Guðmundsson, Júlíus. Minninga rpæettir úr starfi Aðventsafnaðarins á Ísandi. Reykjavík: Frækornið, 1994.

Guðsteinsson, Reynir. “Aðventsöfnuðurinn í Vestmannaeyjum 40 ára.” Blik, 1965, 87.

Guinness, Os. Dining with the Devil: The Megachurch Movement Flirts with Modernity. Grand Rapids, MI: Baker House, 1993.

Hadaway, C. Kirk. Church Growth Principles: Separating Fact from Fiction. Nashville, TN: Broadman Press, 1991.

Hadaway, C. Kirk, and David A. Roozen. Rerouting the Protestant Mainstream: Sources of Growth and Opportunities for Change. Nashville, TN: Abingdon Press, 1995.

Henry, Stuart C. "The Colonial Period: 1736-1784-85." In The History of American Methodism, ed. E. S. Bucke, 1:42-72. Nashville: Abingdon Press, 1964.

Herrington, Jim, Mike Bonem, and James H. Furr. Leading Congregational Change: A Practical Guide for the Transformational Journey. San Francisco, CA: JosseyBass Publishers, 2000.

Hill, Monica, ed. How to Plant Churches. Harrow, England: British Church Growth Association, 1984.

Hobbs, John. "The Relationship Between a Church Growth Strategy and the Numerical Growth of a Small Church." D.Min. dissertation, Harding Graduate School of Religion, 1990. 
Hoge, Dean R., and David A Roozen. Understanding Church Growth and Decline 19501978. New York, NY: Pilgrim Press, 1979.

Hogner, Donald A. World Biblical Commentary: Matthew 14-28. Dallas, TX: Word Books, 1995.

Hohnberger, Jim, with Tim and Julie Canuteson. It's About People. Nampa, ID: Pacific Press, 2003.

Holsclaw, David Francis. "The Demise of Discipline and Christian Fellowship: The Methodist Class Meeting in Nineteenth Century America." Ph.D dissertation, University of California, Davis, 1979.

Hunter, George G., III. "The Bridges of Contagious Evangelism: Social Networks." In Church Growth: State of the Art, ed. C. Peter Wagner with Win Arn and Elmer Towns, 69-82. Wheaton, IL: Tyndale House, 1986.

. Church for the Unchurched. Nashville, TN: Abandon Press, 1996. . How to Reach Secular People. Nashville, TN: Abingdon, 1992. . Radical Outreach: The Recovery of Apostolic Ministry and Evangelism. Nashville, TN: Abingdon Press, 2003.

. To Spread the Power: Church Growth in the Wesleyan Spirit. Nashville, TN: Abingdon Press, 1987.

Hunter, Ken. Foundations for Church Growth. New Haven, MO: Leader Publishing Company, 1983. . Your Church Has Personality. Edited by Lyle E. Schaller. Nashville, TN: Abingdon Press, 1985.

Hurst, John Fletcher. The History of Methodism. Vols. 5 and 6. New York: Eaton and Mains, 1903.

Iceland Conference of SDA. Minutes of the Conference Committee.

Icelandic Mission. Minutes of Meetings of the Mission Committee, 1914-1933, 18 August 1914.

Icenogle, Gareth. The Church in Ministry through Small Group Ministry: An Integrated Approach. Downers Grove, IL: InterVarsity Press, 1993. 
Jochumsson, Matthias. Bréf Matthíasar Jochumssonar. Reykjavík: Bókadeild Menningarsjóðs, 1935.

Johnsson, L. "Efterretninger fra Missionsmarken, Island." Trøstermanden, January, 1898.

Jones, Scott J. The Evangelistic Love of God and Neighbor: A Theology of Witness and Discipleship. Nashville, TN: Abingdon Press, 2003.

Kimball, Dan. The Emerging Church: Vintage Christianity for New Generations. Grand Rapids, MI: Zondervan, 2003.

Kraemer, Hendrik. A Theology of the Laity. Philadelphia, PA: Westminster Press, 1958.

Kristjánsson, Guðni. "Early History and Development of the Seventh-day Adventist Church in Iceland." Research paper, Andrews University, School of Graduate Studies, 1977.

LaRondelle, Hans. How to Understand the End-Time Prophecies of the Bible.

Sarasota, FL: First Impressions, 1997.

Laurie, Greg, with David Kopp. The Upside Down Church. Wheaton, IL: Tyndale House, 1999.

Lehman, Richard, Jack Mahon, and Borge Schantz, eds. Crucial Issues for Witnessing to Western Peoples: Casting the Net on the Right Side. Grantham, England:

Stanborough Press, 1993.

Lingenfelter, Sherwood. Transforming Culture: A Challenge for Christina Mission, $2 \mathrm{~d}$ ed. Grand Rapids, MI: Baker Books, 1998.

Logan, Robert. Beyond Church Growth. Tarrytown, NY: Fleming H. Revell, 1989.

Logan, Robert E., and Thomas T. Clegg. Releasing Your Church's Potential. Carol Stream, IL: ChurchSmart, 1998.

Lovett, Leonard, Opening the Front Door of Your Church. Lanham, MD: Pneuma Life Publishing, 1994.

Luccock, Halford, Paul Hutchinson, and Robert W. Goodloe. The Story of Methodism. New York: Abingdon Press, 1949.

Macchia, Stephen A. Becoming a Healthy Church: 10 Quality Characteristics. Grand Rapids, MI: Baker Books, 1999. 
Malphurs, Aubrey. Developing a Vision for Ministry in the $21^{s t}$ Century. Grand Rapids, MI: Baker Books, 1999.

. The Dynamics of Church Leadership. Grand Rapids, MI: Baker Books, 1999. . Minstry: Nuts and Bolts. Grand Rapids, MI: Kregel Publications, 1997.

. Pouring New Wine into Old Wineskins: How to Change a Church without Destroying It. Grand Rapids, MI: Baker Books, 1993.

.Value-Driven Leadership: Discovering and Developing Your Core Values for Ministry. Grand Rapids, MI: Baker Books, 1996.

Mallison, John. Growing Christians in Small Groups. Sidney, Australia: Anzes Publishers, 1989.

Manley Pippert, Rebecca. How to Lead a Seeker Bible Discussion. Downers Grove, IL: InterVarsity, 2003.

Martin, Carlos G. "Adventist Church Growth." Class Notes for MSSN 600 Principles and Procedures of Church Growth. Silang, Philippines: Adventist International Institute of Advanced Studies, 1998.

Maxwell, C. Mervyn. God Cares. 2 Vols. Boise, ID: Pacific Press. 1985.

McGavran, Donald A. Bridges of God. New York, NY: Friendship Press, 1955.

. Effective Evangelism: A Theological Mandate. Phillipsburg, NJ: Presbyterian and Reformed Publishing Company 1988.

. How Churches Grow. New York, NY: Friendship Press, 1959.

. "Institute of Church Growth." International Review of Missions, 50 (1961). 1990.

Understanding Church Growth, 3d rev. ed. Grand Rapids, MI: Eerdmans, , ed. The Conciliar-Evangelical Debate: The Crucial Documents 1964-1976. Pasadena, CA: William Carey Library. 1977. , ed. Church Growth and Christian Mission. New York, NY: Harper and Row, 1965 
McGavran, Donald, and George G. Hunter, III. Church Growth, Strategies That Work. Creative Leadership Series, ed. Lyle E. Schaller. Nashville, TN: Abingdon Press, 1980.

McGavran, Donald, and Winfried C. Arn. How to Grow a Church. Glendale, CA: Regal Books, 1973.

. Ten Steps for Church Growth. San Francisco, CA: Harpers \& Row, 1977.

McIntosh, Gary, and Glen Martin. Finding Them, Keeping Them. Nashville, TN:

Broadman and Holman Publishers, 1992.

McLaren, Brian D. The Church on the Other Side: Doing Ministry in the Postmodern Matrix. Grand Rapids, MI: Zondervan, 1998, 2000.

. More Ready Than You Realize: Evangelism as Dance in the Postmodern Matrix. Grand Rapids, MI: Zondervan, 2002.

McLaren, Brian D., and Jerry Haselmayer. A Is for Abductive: The Language of the Emerging Church. Grand Rapids, MI: Zondervan, 2003.

McQuoid, Stephen. Sharing the Good News in C21: Evangelism in a Local Church Context. Guildford, England: Paternoster Press, 2002.

Mead, Loren B. More Than Numbers: The Way Churches Grow. New York, NY: Alban Institute, 1995.

. The Once and Future Church. New York, NY: Alban Institute, 1991.

Methodist Episcopal Church. The Doctrines and Discipline of the Methodist Episcopal Church. New York: Carlton and Porter, 1856.

Michael, Otto. "The Conclusions of Matthew's Gospel." In The Interpretation of Matthew, ed. Graham N. Staton, 17. Philadelphia, PA: Fortress Press, 1980.

Miles, Delos. Church Growth: A Mighty River. Nashville, TN: Broadman Press, 1981.

Miller, John. Outgrowing and Ingrowing Church. Grand Rapids, MI: Zondervan, 1999.

Milosavljevic, Radivoje Rade. "Master Planning for Church Growth in Serbia." D.Min. dissertation, Andrews University, 2001.

Mittelberg, Mark. Building a Contagious Church: Revolutionizing the Way We View and Do Evangelism. Grand Rapids, MI: Zondervan, 2000. 
Moerman, Murray, ed. Transforming Our Nation. Richmond, British Columbia: Church Leadership Library, 1998.

Moore, T. M. Preparing Your Church for Revival. Carol Stream, IL: ChurchSmart, 2001.

Morgenthaler, Sally. Worship Evangelism. Grand Rapids, MI: Zondervan, 1995.

Mounce, R. H. The Book of Revelation. The New International Commentary on the New Testament. Grand Rapids, MI: Eerdmans, 1977.

Murphy, Nancey. Philosophical Resources for Postmodern Evangelical Theology. New York: Macmillan, 1990.

Neuhaus, Richard. "After Modernity." The Religion and Society Report 5 (February 1988): 1-2.

Newbigin, Lesslie. Mission in Christ's Way: A Gift, a Command, an Assurance. New York, NY: Friendship Press, 1987. . The Open Secret, rev. ed. Grand Rapids, MI: Eerdmans, 1995.

Newman, J. David. “The Cross, the Center of Worship.” Ministry, October 1991, 4.

Nida, Eugene A. Message and Mission: The Communication of the Christian Faith. Pasadena, CA: William Carey Library, 1990.

Norwood, Frederick A. "The Church Takes Shape." In The History of American Methodism, ed. E. S. Bucke, 1:419-488. Nashville, TN: Abingdon Press, 1964.

Ogden, Greg. Unfinished Business: Returning the Ministry to the People of God. Grand Rapids, MI: Zondervan, 1990, 2003.

Olsen, Olav Johan. "Beretning fra O. J. Olsen." Evangeliets Sendebud (September 1914): 540. . Interview, May 1976. . "Island," Missionsefterretninger, January 1929, 4. . "Island-Onsrud," Brceðrabandið, September-November, 1933, 81. . "Island," Missionsefterretninger, June 1921, 57. . “Kirkjuvígsla," Brææðrabandið, February 1926. 
. Minutes of Meeting, 16 May 1924.

. "Vestmannoerne, Island," Missionsefter-retninger, May 1923,.

Oosterwal, Gottfried. Patterns of SDA Growth in North America. Berrien Springs, MI: Andrews University Press, 1976.

Östlund, David. "Reykjavik, Island," Evangeliets Sendebud, December 1904, 399.

. "Reykjavik, Island," Trostermanden, April 1898.

Outler, Albert C. "The Wesleyan Quadrilateral-In John Wesley." In Doctrine and Theology in the United Methodist Church, ed. Thomas A. Langford. Nashville, TN: Kingswood Books-Abingdon Press, 1991.

Padilla, C. René. "The Unity of the Church and the Homogeneous Unit Principle." In Exploring Church Growth, ed. Wilbert R. Shenk, 285-302. Grand Rapids, MI: Eerdmans, 1983.

Pálsson, Guðmundur. "Fra Island." Missionsefterretninger, August 1921.

Paulien, Jon. Present Truth in the Real World. Boise, ID: Pacific Press Publishing Association, 1993.

Percy, Harold. Your Church Can Thrive. Nashville, TN: Abingdon Press, 2003.

Pétursson, Pétur. Church and Social Change: A Study of the Secularization Process in Iceland 1830-1930. Vanersborg, Sweden: Plus Ultra, 1983.

. Från väckelse til samfund-Svensk pingstmission i öerna i Nordatlanten. Lund, Bibliotheca Historico-Ecclesiastica Lundensis 22: Lund University Press, 1990. 149-156.

. "Religiösa minoriteter på Island," Kyrkohistorisk Aarsskirft Volume (1989):

. "Revivalism and Lay Religious Movements on Iceland: A Survey and an Account of the Current State of Reserarch," Scandinavian Journal of History 11 (1986): 335-344.

Pickett, J. Wascom. Christian Mass Movements in India. New York, NY: Abingdon Press, 1933.

Pinola, Sakari. Church Growth Principles and Praxis of Donald A. McGavran's Missiology. Aabo, Sweden: Aabo Akademis Forlag, 1995. 
Powell, Paul W. The Nuts and Bolts of Church Growth. Nashville, TN: Broadman Press, 1982.

Rack, Henry. "The Decline of the Class Meeting and the Problem of Church Membership in Nineteenth Century Wesleyanism." Proceedings of the Wesleyan Historical Society 39 (1973-1974): 12-21.

Raft, J. C. "Iceland." The General Conference Bulletin, May 1909, 127.

Rainer, Thom S. The Book on Church Growth: History, Theology and Principles. Nashville, TN: Broadman Press, 1993.

. Eating the Elephant: Bite-Sized Steps to Achieve Long-Term Growth in Your Church. Nashville, TN: Broadman \& Holman, 1994.

. Effective Evangelistic Churches. Nashville, TN: Broadman \& Holman, 1996.

. Giant Awakenings. Nashville, TN: Broadman \& Holman Publishers, 1995.

. High Expectations: The Remarkable Secret for Keeping People in Your

Church. Nashville, TN: Broadman \& Holman, 1999. 2001.

. Surprising Insights from the Unchurched. Grand Rapids, MI: Zondervan, . The Unchurched Next Door. Grand Rapids, MI: Zondervan, 2003.

Read, W. E. "Island." Missionsefterretninger," February 1924, 13.

Reece, Richard. "A Eighth Letter from the Rev. Richard Reece on the Subject of His Late Visit to America." Wesleyan-Methodist Magazine, December 1825, 841.

Regele, Mike. Death of the Church. Grand Rapids, TN: Zondervan, 1995.

Roozen, David A., and Jackson W. Carroll. "Recent Trends in Church Membership and Participation: An Introduction." In Understanding Church Growth and Decline 1950-1978, ed. Dean R. Hoge and David A. Roozen, 21-41. New York, NY: Pilgrim Press, 1979.

Rorty, Richard. Consequences of Pragmatism: Essays 1972-1980. Minneapolis, MN: University of Minnesota Press, 1982.

Roy, Ruthven. A Challenge to the Remnant: Designing Our Mission Strategy to Impact the Real World. Frederick, MD: N. D. M. Books, 2002. 
Sahlin, Monte. Adventist Congregations Today: New Evidence for Equipping Healthy Churches. Lincoln, NE: Center for Creative Ministry, 2003.

Schaller, Lyle. 44 Steps Up Off the Plateau. Nashville, TN: Abingdon Press, 1993. . The Seven-Day-a-Week Church. Nashville, TN: Abingdon Press, 1992. . What Have We Learned? Nashville, TN: Abingdon Press, 2001.

Schneiders, Sandra M. "Does the Bible Have a Postmodern Message?" In Postmodern Theology: Christian Faith in a Pluralistic World, ed. Frederic B. Burnham. New York: Harper \& Row, 1989.

Schuller, Robert. "Three Characteristics of a Successful Pastor." In The Pastor's Church Growth Handbook, ed. Win Arn. Pasadena, CA: Church Growth Press, 1979.

Schwarz, Christian. Natural Church Development. Carol Stream, IL: ChurchSmart Resources, 1996. . Paradigm Shift in the Church: How Natural Church Development Can Transform Theological Thinking. Carol Stream, IL: ChurchSmart Resources, 1997.

Schwarz, Christian A., and Christolph Schalk. Implementation Guide to the Natural Church Development. Carol Stream, IL: ChurchSmart, 1998.

Seventh-day Adventist Encyclopedia, 1975 ed. S. v. "Iceland."

Seventh-day Adventist Bible Commentary. Edited by F. D. Nichol. Washington DC: Review and Herald, 1953-57. 7:827. "Another."

Shader, Dan, and Gary Makers. Growing Healthy Churches. Chicago, IL: Moody Press, 1991.

Shawchuch, Norman, and Gustave Rath. Benchmarks of Quality in the Church. Nashville, TN: Abingdon Press, 1994.

Shenk, Wilbert R., ed. Exploring Church Growth. Grand Rapids, MI: Eerdmans, 1987 , "Church Growth Study: A Bibliography Overview." In The Challenge of Church Growth: A Symposium, ed Wilbert A. Shenk. Elkhart, IN: Institute of Mennonite Studies, 1973.

Sherwood, Lawrence. "Growth and Spread, 1785-1804." In The History of American Methodism, ed. E. S. Bucke, 1:360-419. Nashville, TN: Abingdon Press, 1964. 
Sigurbjörnsson, Karl. Fyrsta Fríkirkjan á Íslandi. Reykjavík, 1973. Unpublished paper.

Sigurơsson, Pétur. “Fra Island” Missionsefterretninger, May 1917.

. "Bolungavik." Missionsefterretninger., June 1917.

Sire, James. "Logocentricism and Postmodern Apologetics." Calvin Theological Journal 26 (1991): 412.

Smith, Ebbie, C. Balanced Church Growth: Churched Growth Based on the Model of Servanthood. Nashville, TN: Broadman Press, 1984. 1976.

. A Manual for Church Growth Surveys. Pasadena, CA: William Carey Library,

Snorrason, Björgvin. "Pastor David Östlund and the Beginnings of the Seventh-day Adventist Church in Iceland." Research paper, Andrews University, School of Graduate Studies, 1975.

. "The Three Angels' Messages Reach Iceland." Research paper, Seventh-day Adventist Theological Seminary, Andrews University, 1986.

Southerland, Dan. Transitioning. Grand Rapids, MI: Zondervan, 1999.

Spretnak, Charlene. States of Grace: The Recovery of Meaning in a Postmodern Age. San Francisco: HarperCollins, 1991.

Statistical Yearbook of Iceland. Reykjavík: Statistical Bureau of Iceland, 1998. [CDRom].

Staton, Graham N., ed. The Interpretation of Matthew. Philadelphia: Fortress Press, 1983.

Steinke, Peter. Healthy Congregations: A Systems Approach. Bethesda, MD: Alan Institute, 1996.

Stetzer, Ed. Planting Churches in a Postmodern Age. Nashville, TN: Broadman \& Holman, 2003.

Stevens, Abel. A Compendious History of American Methodism. New York: Easton and Mains, 1868.

Strobel, Lee. Inside the Mind of Unchurched Harry and Mary. Grand Rapids, TN: Zondervan, 1993. 
Sweet, Leonard, Brian McLaren, and Jerry Haselmayer. A Is for Abductive: The Language of the Emerging Church. Grand Rapids, MI: Zondervan, 2003.

Sweet, William Warren. Religion on the American Frontier 1783-1840. Vol. 4, The Methodists. Chicago: University of Chicago Press, 1946.

Taber, Charles R. "Contextualization." In Exploring Church Growth, ed. Wilbert R. Shenk. Grand Rapids, MI: Eerdmans, 1983.

Telford, Jon, ed. The Letters of Rev. John Wesley, A.M. Vol. 6, A Letter to William Church, October 13, 1778. London: Epworth Press, 1931.

Thordarson, Steinthor B (Steinpór B. Pórðarsson). "A Study of Factors Related to the Numerical Growth of the Seventh-day Adventist Church in Iceland from 1950 to 1980." D.Min. dissertation, Andrews University, 1985.

Tippett, A. R."Portrait of a Missiologist by His Colleagues." In God, Man, and Church Growth, ed. A. R. Tippett, 21, 22. Grand Rapids, MI: Eerdmans, 1973.

Torres, Louis R. Gaining Decisions for Christ. Hagerstown, MD: Review and Herald, 2001.

Towns, Elmer, John N. Vaughan, and David J Seifert. The Complete Book of Church Growth. Wheaton, IL: Tyndale House, 1982.

Towns, Elmer, C. Peter Wagner, and Thom S. Rainer. The Everychurch Guide to Growth: How Any Plateaued Church Can Grow. Nashville, TN: Broadman \& Holman, 1998.

Van Engen, Charles. God's Missionary People: Rethinking the Purpose of the Local Church. Grand Rapids, MI: Baker Book House, 1995.

. The Growth of the True Church: An Analysis of the Ecclesiology of Church Growth Theory. Amsterdam, Netherlands: Rodopi B. V., 1981.

Van Wyk, Kenneth. "A Workable Model for Training the Laity." In The Pastor's Church Growth Handbook, ed. Win Arn. Pasadena, CA: Church Growth Press, 1979.

Wagner, C. Peter. Church Growth and the Whole Gospel: A Biblical Mandate. San Francisco, CA: Harper \& Row, 1981.

. "Church Growth Research: The Paradigm and Its Applications." In Understanding Church Growth and Decline 1950-1978, ed. Dean R. Hoge and David A. Roozen, 270-287. New York, NY: Pilgrim Press, 1979, 
. Churchquake. Ventura, CA: Regal Books, 1999.

."Donald McGavran: A Tribute." In Church Growth: State of the Art, ed. C.

Peter Wagner and others, 15-19. Wheaton, IL: Tyndale House, 1986.

. The Healthy Church. Ventura, CA: Regal Books, 1996.

. Our Kind of People: The Ethical Dimensions of Church Growth in America. Atlanta, GA: John Knox Press, 1979. 1979.

. Spiritual Gifts Can Help Your Church Grow. Ventura, CA: Regal Books,

. Spiritual Power and Church Growth: Lessons from the Amazing Growth of Pentecostal Churches in Latin America. Altamonte Springs, FL: Strang Communications, 1986.

. Strategies for Church Growth. Ventura, CA: Regal Books, 1987.

. Your Church Can Be Healthy. Nashville, TN: Abingdon, 1979.

. Your Church Can Grow. Ventura, CA: Regal Books, 1976.

Wagner, C. Peter, with Win Arn and Elmer Towns, eds. Church Growth, State of the Art. Wheaton, IL: Tyndale House, 1986.

Ward, Reginald W., and Richard P. Heilzenrater, eds. The Works of John Weslery, Journal and Diaries. Nashville, TN: Abingdon Press, 9:318.

Warren, Rick. The Purpose Driven Church. Grand Rapids, MI: Zondervan, 1995

Watkins, Morris. The Great Commission: Study Guide. Fullerton, CA: R. C. Law \& Co., Inc., 1987.

Watson, David Lowes. The Early Methodist Class Meeting: Its Origins and Significance, rev. ed. Nashville: Discipleship Resources, 1987.

Werning, Waldo J. The Seed Planting Church: Nurturing Church to Health. Carol Stream, IL: ChurchSmart, 2003.

. Twelve Pillars of a Healthy Church. Carol Stream, IL: ChurchSmart, 1995.

.Visions and Strategies for Church Growth. Grand Rapids, MI: Baker Books, 1983. 
Wesley, John. "A Letter to William Church, October 13, 1778." In Letters of Rev. John Wesley, A. M., ed. John Telford, 6:324-325. London: Epworth Press, 1931.

. "A Plain Account of the People Called Methodists." In The Works of John Wesley, ed. Rupert Davies, 9:254-280. Nashville: Abingdon Press, 1989.

. The Works of John Wesley. Edited by Reginald W. Ward and Richard P. Heilzenrater. Vols. 9 and 21. Nashville: Abingdon Press, 1990.

White, Charles Edward. "John Wesley's Use of Church Discipline." Methodist History 29 (January 1991): 112-118.

White, Ellen G. Acts of the Apostles. Mountain View, CA: Pacific Press, 1911.

. "Appeal and Suggestions for Conference Officers." Ellen G. White Pamphlets in the Concordance. Payson, AZ: Leaves-of-Autumn, 1983.

. Christian Experience and Teachings of Ellen G. White. Mountain View, CA: Pacific Press, 1940.

. The Complete Published Ellen G. White Writings. Silver Spring, MD: The Ellen G. White Estate, Inc., 1998 [CD Rom].

. Conflict and Courage. Washington, DC: Review and Herald, 1970.

. The Desire of Ages. Mountain View, CA: Pacific Press, 1940.

. "The Duties of the Minister and the People." Review and Herald, July 9, 1895.

. Evangelism. Washington, DC: Review and Herald, 1946.

. The Faith I Live By. Washington, DC: Review and Herald, 1958. 1895.

"Followers of Christ Will Be Missionaries." Review and Herald, January 8,

. "Go into All the World." Review and Herald, June 11, 1895.

. Gospel Workers. Washington, DC: Review and Herald, 1892.

. Gospel Workers. Washington, DC: Review and Herald, 1948.

. The Great Controversy. Mountain View, CA: Pacific Press,1939.

. Life Sketches of Ellen G. White. Mountain View, CA: Pacific Press, 1943. 
. Manuscript Releases. Silver Spring, MD: Ellen G. White Estate, 1994.

13:208-209.

. Ministry of Healing. Mountain View, CA: Pacific Press,1942.

. Reflecting Christ. Hagerstown, MD: Review and Herald, 1985. 108 .

. Selected Messages. 3 Vols. Washington, DC: Review and Herald 1959. 2:107-

. Sermons and Talks. Silver Spring, MD: Ellen G. White Estate, 1994.

. Sketches from the Life of Paul. Washington, DC: Review and Herald, 1974.

. Spalding and Magan Unpublished Manuscript Testimonies of Ellen G. White.

Payson, AZ: Leaves-of-Autumn, 1982.

. Sons and Daughters of God. Washington, DC: Review and Herald, 1955.

. Testimonies to Ministers. Mountain View, CA: Pacific Press, 1962.

. Testimonies for the Church. 9 Vols. Mountain View, CA: Pacific Press, 1948.

. "The Test of Loyalty." Signs of the Times, February 13, 1896, 7.

."The Work in Greater New York." Atlantic Union Gleaner, January 8, 1909.

White, James Emery. Opening the Front Door: Worship and Church Growth. Nashville, TN: Convention Press, 1992.

. Rethinking the Church: A Challenge to Creative Redesign in an Age of Transition, rev. ed. Grand Rapids, MI: Baker Books, 2003.

White, Tom. City-Wide Prayer Movement: One Church, Many Congregations. Ann Arbor, MI: Servant Publications, 2001.

Wickham, E. R. Church and People in an Industrial City. London, England: Lutterworth Press, 1957.

Wigger, John H. "Taking Heaven by Storm: Methodism and the Popularization of American Christianity 1770-1 820." Ph.D. dissertation, University of Notre Dame, 1994.

Wilson, Marlene. How to Mobilize Church Volunteers. Minneapolis, MN: Augsburg Publishing House, 1983. 
Womack, David A. The Pyramid Principle of Church Growth. Minneapolis, MN: Bethany Fellowship, 1977.

Wood, Christine. Character Witness: How Our Lives Can Make a Difference in Evangelism. Downers Grove, IL: InterVarsity Press, 2003.

Wood, A. Skevington. The Burning Heart: John Wesley, Evangelist. Grand Rapids, MI: Eerdmans, 1967.

Young, John M. L. "The Place and Importance of Numerical Church Growth." In Theological Perspectives on Church Growth, ed. Harvie M. Conn. The Den Dulk Foundation, 1976.

Zunkel, C. Wayne. Church Growth Under Fire. Scottsdale, PA: Herald Press, 1987.

Zustiak, Gary. The Next Generation: Understanding and Meeting the Needs of Generation $X$ Joplin, MO: College Press Publishing Company, 1996. 


\section{VITAE}

Eric Guðmundsson was born into an SDA family in Reykjavík, Iceland, on July 25,1949 . Upon completing elementary school he attended the SDA secondary school, Hliðardalsskóli, in Iceland from 1963 to 1966 and Gagnfræðaskóla Austurbæjar in Reykjavík 1967. While at Hliðardalsskóli he was baptized into the Seventh-day Adventist Church (1964).

Degrees Awarded:

Authorized Physiotherapist, Skodsbord School of Physiotherapy, 1973

Bachelor of Arts in Theology, Newbold College, 1976

Master of Divinity, Andrews University, 1984

Doctor of Ministry, Andrews University, 2006

Professional Experience:

1978-1982 Hospital chaplain, Masanga Leprosy Hospital, Sierra Leone, West Africa

1984-1997 Conference president, Iceland Conference of SDA

1998-2006 Pastor, Árnes and Vestmannæyjar SDA churches and conference departmental director, Iceland

2006- Conference president, Iceland Conference of SDA and pastor, Reykjavík, Iceland 